(2) norden

Nordic agriculture air and climate

Baseline and system analysis report

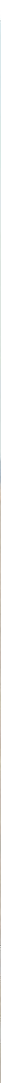







\section{Nordic agriculture air and climate}

Baseline and system analysis report

Anne Antman, Stein Brubæk, Bente Hessellund Andersen, Kajsa Lindqvist, Miriam Markus-Johansson, Jacob Sørensen and Jenny Teerikangas 
Nordic agriculture air and climate

Baseline and system analysis report

Anne Antman, Stein Brubæk, Bente Hessellund Andersen, Kajsa Lindqvist, Miriam Markus-Johansson, Jacob Sørensen and Jenny Teerikangas

ISBN 978-92-893-4319-0 (PRINT)

ISBN 978-92-893-4321-3 (PDF)

ISBN 978-92-893-4320-6 (EPUB)

http://dx.doi.org/10.6027/TN2015-570

TemaNord 2015:570

ISSN 0908-6692

(C) Nordic Council of Ministers 2015

Layout: Hanne Lebech

Cover photo: Jacob Sørensen

Print: Rosendahls-Schultz Grafisk

Printed in Denmark
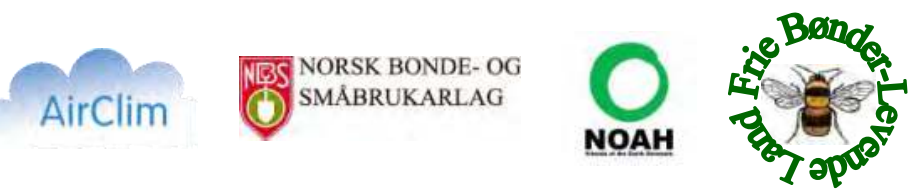

This publication has been published with financial support by the Nordic Council of Ministers. However, the contents of this publication do not necessarily reflect the views, policies or recommendations of the Nordic Council of Ministers.

\section{www.norden.org/nordpub}

\section{Nordic co-operation}

Nordic co-operation is one of the world's most extensive forms of regional collaboration, involving Denmark, Finland, Iceland, Norway, Sweden, and the Faroe Islands, Greenland, and Åland.

Nordic co-operation has firm traditions in politics, the economy, and culture. It plays an important role in European and international collaboration, and aims at creating a strong Nordic community in a strong Europe.

Nordic co-operation seeks to safeguard Nordic and regional interests and principles in the global community. Common Nordic values help the region solidify its position as one of the world's most innovative and competitive.

\section{Nordic Council of Ministers}

Ved Stranden 18

DK-1061 Copenhagen $\mathrm{K}$

Phone (+45) 33960200

www.norden.org 


\section{Contents}

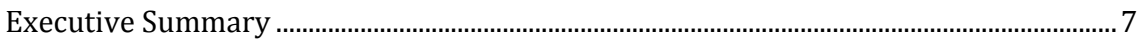

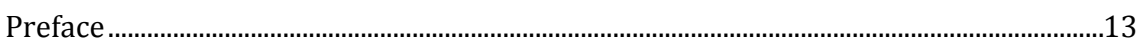

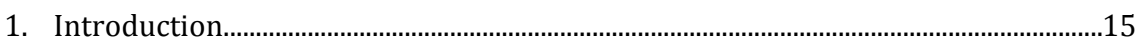

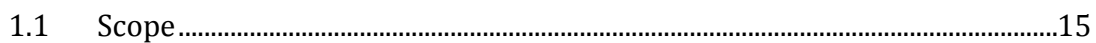

1.2 Target groups .......................................................................................................16

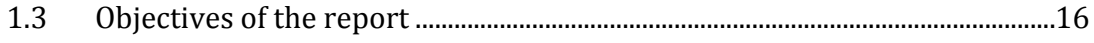

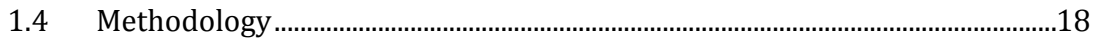

1.5 Policy context.........................................................................................................19

2. Agriculture in the Nordic countries........................................................................21

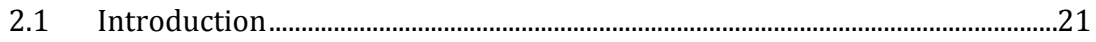

2.2 Agricultural structures and land uses............................................................21

2.3 Agricultural production ..................................................................................23

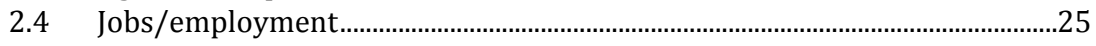

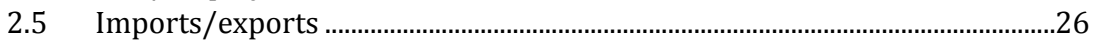

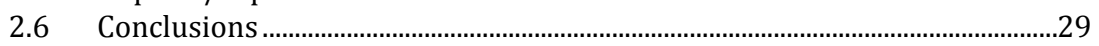

3. Agriculture, greenhouse gases and air pollutants .........................................................31

3.1 Overview of significant pollutants .......................................................................

3.2 Overview of national agricultural emissions ..................................................33

3.3 Emissions per pollutant and country .................................................................35

3.4 Projected emissions.................................................................................................4

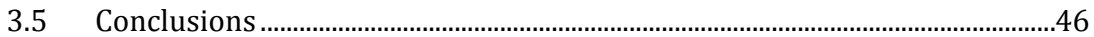

4. Manure regulation, incentives for emission control and conflicts of

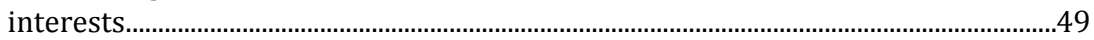

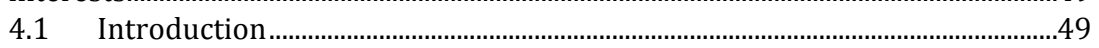

4.2 Legislative framework on manure regulation.................................................50

4.3 Current measures and incentives ..........................................................................53

4.4 Conflicts of interests - some examples.................................................................5

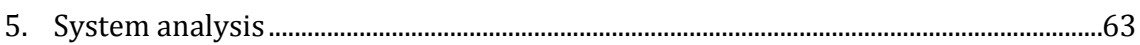

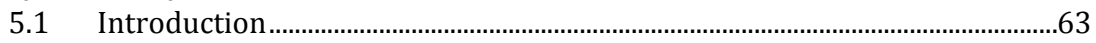

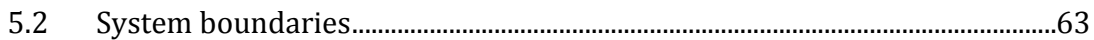

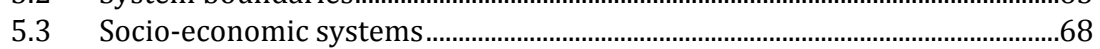

5.4 Synthesis: Towards an integrated system model ...............................................73

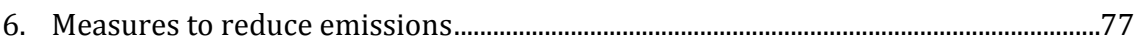

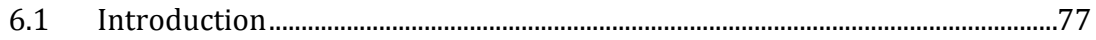

6.2 Inventory of measures.......................................................................................78

6.3 Cases studies on emission-reducing practices ...................................................96

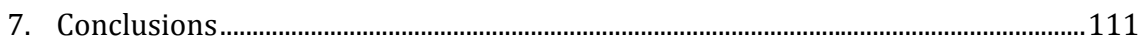

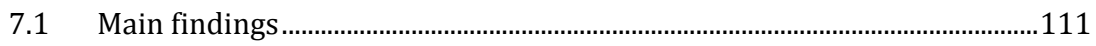

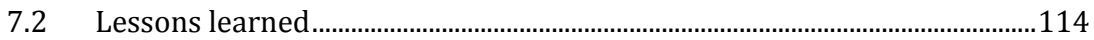

7.3 Preliminary recommendations.........................................................................115

Tables and figures....................................................................................................117

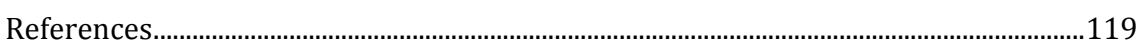




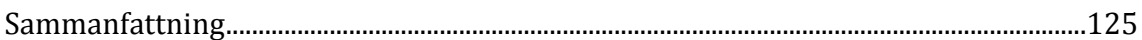

Rapportens huvudsakliga slutledningar.................................................................127

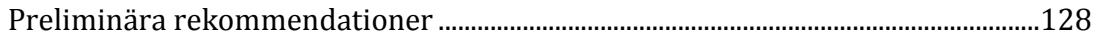

Annex 1: National Report: Agriculture in Denmark .......................................................131

Introduction .............................................................................................................131

A brief description of the agricultural sector over a 30 year-period......................131

Agricultural emissions of greenhouse gases and ammonia -

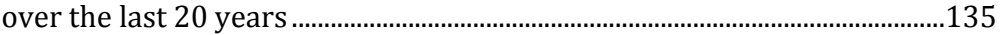

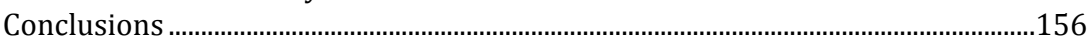

Tables and figures .....................................................................................................157

Annex 2: National Report: Agriculture in Norway ………...............................................159

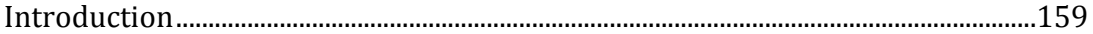

A brief description of the agricultural sector...........................................................159

Agricultural emissions of greenhouse gases - over 20 years ..................................164

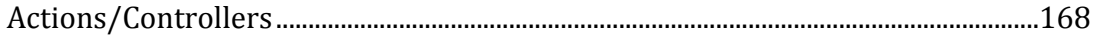

Tables and figures .........................................................................................................169

Annex 3: National Report: Agriculture in Sweden ........................................................171

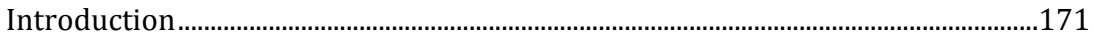

A brief description of the agricultural sector - 30 years back.................................171

Agricultural emissions of greenhouse gases and ammonia now and 20 years back ....................................................................................173

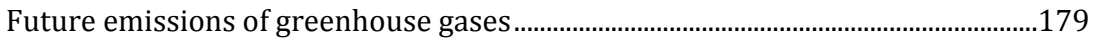

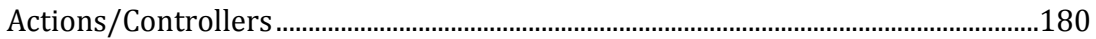

Annex 4: National Report: Agriculture in Finland...........................................................185

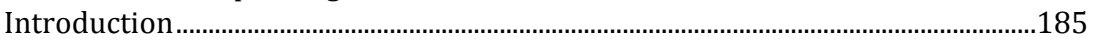

A brief description of the agricultural sector - now and 30 years back................185

Agricultural emissions - now and 20 years back.......................................................189

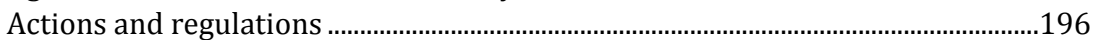

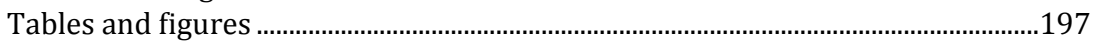




\section{Executive Summary}

This report constitutes one of the main outputs of the project "Pathways to a Nordic food system that contributes to reduced emissions of greenhouse gases and air pollutants". The project is financed by the Nordic Council of Ministers and began in 2013. The content and findings of this report are partly based on inputs from the participating organisations, a number of project workshops and regular project meetings.

The two overall goals of this report are firstly to present the status quo or baseline data and information regarding the Nordic agricultural sector, its greenhouse gas and ammonia emissions, the regulatory framework and support systems, and conflicts of interest. Secondly the report aims to describe paths towards an agricultural system that contributes to achieving the set climate and air pollution targets.

The Nordic region is culturally, social and economically very homogenous, but has diverse geological and climatic conditions that make certain types of agricultural production more vulnerable than others. One common factor is that a relatively small proportion of the total land territory is used for agricultural production; between 3-8\%, except for Denmark, which has more than half of its territory designated for agricultural production.

There is a general reduction in the number of dairy herds but an increase in yield per milk cow. The number of farms with cattle has also decreased greatly in the Nordic countries, leading to increased demand for imported meat in some cases. Employment in the agricultural sector is very low - estimated at around $2-3 \%$ of the total workforce, with an average age above 50. In terms of production of grain, meat and other agricultural products, there are some variations between the countries. One general trend is a decline in the production of beef in favour of poultry and pork.

In terms of emissions, the share of the greenhouse gases methane and nitrous oxide from agriculture in the Nordic countries is 8 and 9\% respectively in Norway and Finland, whereas it is as high as $13 \%$ in Sweden and 19\% in Denmark. The share of emissions is substantially higher in all the countries when emissions from land use, land use changes and energy consumption are included. When these emissions are included, the share is as high as $27 \%$ in Denmark. More 
emissions are connected to imported goods used in agriculture, such as feed and fertilisers.

Nitrous oxide emissions from agriculture are the highest in Denmark, at $90 \%$, and the lowest in Finland. All of the countries, except Norway, have seen a reduction in nitrous oxide emissions, which is partly due to decreased use of nitrogen fertiliser. Methane emissions have remained steady over the past 20 years.

Ammonia emissions are another significant form of emissions from the agricultural sector, accounting for approximately $90 \%$ on average in the Nordic countries. Livestock manure is the main source of all ammonia emissions in the Nordic countries, ranging between $80-90 \%$, and these levels are unlikely to drop significantly without the right measures and policies in place.

In terms of regulatory framework and control mechanisms, all the countries have rules on the spreading, storing and use of manure, with the Danish regulations being the most rigorous. Some incentive and support systems have been put into place that can either work in favour of or constitute barriers to a paradigm shift in Nordic agricultural and food systems. For instance, the present support systems for agriculture have mainly favoured more intensive and large-scale farming. Another fact of significance is that growth in production has historically been central to agricultural policy, while other interests were subordinated.

It is also clear that agriculture today does not pay for the external environmental and health costs that the emissions from agriculture cause. The use of environmental taxes is limited, in that emissions are often diffuse and difficult to measure. Furthermore, competition in a global market (and especially in the $\mathrm{EU}$ ) is another factor limiting the recourse to taxes.

Furthermore, there are conflicts of interest that are counterproductive of an agricultural sector with lower greenhouse gas and ammonia emissions. The main conflicts covered in the report include animal welfare, biodiversity and cultural landscapes, the limitations of farmers' income, the demand for cheap food, the limiting context of free trade and general challenges of globalising agricultural production, various land use interests and the lack of transparency that makes it easier for some interests to earn a lot of money from the current system. Hence, before deciding on policy, technical, organisational and fiscal measures that have an impact on the emissions from the agricultural sector, it is important to consider whether these measures entail threats to animal health and welfare, whether they oppose other land use purposes, and whether we still comply with binding free trade regulations. 
There are many links and dependencies between the various elements and factors that affect agricultural systems and food systems. Chapter 5 sets out an integrated systems analysis depicted through a number of "causal loop diagrams". This systems analysis points to the central importance of what we refer to as the "environmental and social awareness" of the public. Theoretically, in a transparent and working democracy, increased public awareness would lead to the internalisation of the environmental costs associated with intensive farming, a revision of the subsidies system that promotes low agricultural product prices, and a re-evaluation of consumer choices regarding the consumption of crop and animal products. However, in practice, more measures and awareness-raising are necessary to achieve this internalisation of environmental costs and to achieve a paradigm shift in agricultural production and consumption of agricultural products.

In order to see to what degree a variety of complementary measures is used to restrict emissions from the agricultural sector, we have made an inventory of measures, divided into various categories, i.e. manure and fertiliser management, energy efficiency, feeding, land use, production of energy from the agricultural sector, and other measures. The measures most frequently used on a regular basis are in the first category of measures, i.e. manure handling and fertilisation. These include: 1 ) decreasing the time over which emissions can take place, 2) covering of slurry tanks, 3) covering and/or turning over of solid manure heaps, 4) optimising fertilization, 5) decreasing the surface area where emissions can take place, 6) increasing the use of green manure (legumes) in fields.

The category of measures most scarcely used was energy efficiency measures, e.g. using energy-efficient ventilation systems, reducing energy use from milking, and replacing diesel with renewable fuels. Energy production from agricultural input (biomass, manure, straw) is also seldom deployed; however this practice is also controversial in relation to possible displacement of food production and/or carbon depletion in soils. Regarding measures that relate to food and consumption that will bring down carbon emissions, including decreasing the number of animals, reducing meat, milk and egg production - the most frequently used measure was linked to "reducing food waste". 
Among the main findings of the report were:

- The value of exchanging practices and knowledge is immeasurable. Practices that work in one country may work in another and increased understanding of how the agricultural sector has developed in the different Nordic countries can give valuable insights for developing solutions that can reduce emissions from agriculture and enhance carbon sequestration.

- There is an increasing need for a better understanding of conflicts of interest that are limiting the playing field as a result of various technical, organisational and policy measures.

- The emission reductions, policies and tools that are used are largely dependent on local conditions, consumption patterns, the overall policy context, and the balance between imports and exports of agricultural produce.

- More incentives are needed to promote greenhouse gas reduction measures at farm level. Many of the farms are of smaller size and the individual farmer cannot be expected to take rather expensive measures to contain emissions, so there is a need to develop understanding and measures suitable for smaller farms.

- There is a need for more dietary guidance not only based on health parameters but also on the effects of diet on emission levels and the contribution to achieving climate change targets.

- More measures and awareness-raising are necessary to achieve an internalisation of environmental costs and to achieve a paradigm shift in agricultural production and consumption of agricultural products. 
The preliminary recommendations that will lead into the next phase of the project involving a series of national seminars and scenario cases include:

- All countries need to have an adequate regulatory framework comprising manure management and limits on the use of organic soils for farming to help bring down carbon emissions. It is also important to develop and promote practices for covered manure and slurry storage to limit the fermentation process and reduce emissions.

- Further explore how to increase use of the measures set out in the inventory in chapter 6 and to what extent this should be done. Particularly underused are measures related to energy-efficient use, production and consumption. Some of these measures take place at farm level, whereas others (especially measures relating to production and consumption) require action at a political level.

- Promote sustainable farming as a profession, especially among younger generations and extend and further develop the incentive schemes that are already in place.

- Strive towards a paradigm shift in how we perceive agricultural production, food systems and consumption, with a view to striking a balance between various dilemmas and conflicts in the production systems, the import/export balance, consumption patterns, and how we perceive efficiency in the farming sector and take into account environmental and climate impact factors.

- Start working towards an integrated food and agricultural policy, which also takes into account global concerns regarding poverty and unequal access to food. The Nordic policies should not be in conflict with such global concerns, in line with FAO guidelines and other relevant international policies and recommendations. 



\section{Preface}

This report constitutes one of the main outputs of the project "Pathways to a Nordic food system that contributes to reduced emissions of greenhouse gases and air pollutants". This project is financed by the Nordic Council of Ministers and commenced in 2013.

The overall objective of the project is to describe the status quo in emission trends but equally importantly to explore and describe paths towards an agricultural system and pathways to a Nordic food system that contribute to achieving the climate target of below 2 (or 1.5) degrees of warming and the air pollution target of zero exceedance of critical loads and critical levels regarding ammonia emissions. Actual reductions in carbon dioxide, methane, and nitrous oxide emissions from the agriculture sector would contribute to reducing important global greenhouse gases. Reductions in methane emissions would also limit the formation of ground-level ozone.

The outputs, results, lessons learned and policy recommendations developed within the project may serve as inputs that influence climate, air pollution control and agricultural policies at EU, Nordic and national level. Project findings may also add value to an overall analysis of issues affecting agriculture and land use in the international climate negotiations as well as international biodiversity negotiations. We would also like to highlight possible synergies in the agricultural sector by addressing air pollution and greenhouse gases jointly. This first phase of the project has focused on describing Nordic agriculture production, land use, and the current and forecast levels of greenhouse gas and ammonia emissions. This report is the main output of this phase. These findings, and in particular the data and methodology developed in the integrated analysis of various relations between factors and emissions, will feed into the next phase in which the project partners will establish a scenario for "A new Nordic food system's contribution to global sustainable food systems and climate mitigation". 


\begin{tabular}{lll}
$\begin{array}{l}\text { Table 1: Participants in this project and main authors of the report } \\
\text { Organisation }\end{array}$ & Contact person & Contact details \\
$\begin{array}{l}\text { Miljøbevægelsen NOAH and } \\
\text { Frie Bønder - Levende land }\end{array}$ & Bente Hessellund Andersen & bente.hessellund@gmail.com \\
$\begin{array}{l}\text { The Finnish Society for Nature } \\
\text { and the Environment }\end{array}$ & Anne Antman & anne.antman@naturochmiljo.fi \\
$\begin{array}{l}\text { The Finnish Association for Nature } \\
\text { Conservation }\end{array}$ & Jenny Teerikangas & jenny.teerikangas@sll.fi \\
Norsk Bonde- og Småbrukarlag & Stein Brubæk & stein359@gmail.com \\
$\begin{array}{l}\text { The Air Pollution and Climate } \\
\text { Secretariat }\end{array}$ & Kajsa Lindqvist & kajsa.lindqvist@airclim.org \\
\hline
\end{tabular}

These organisations have actively contributed to this report and to the workshops and working materials on which this report has been based. Input and contributions have also been received by other national organisations with which these organisations are affiliated.

The information and findings in this report are predominantly based on the national reports the project team put together during spring 2014. It also takes into account other contributions, analysis and statistical data and projections that the project team put together during workshops. The authors of this report are: Stein Brubæk, Bente Hessellund Andersen, Kajsa Lindqvist, Miriam Markus-Johansson, Anne Antman, Jenny Teerikangas and Jacob Sørensen. We also want to extend our gratitude to a number of other people who contributed data, projections and views, including Tarja Haaranen (Natural Resources Institute Finland), Marja-Liisa Tapio-Biström and Hanna Mattila (the Ministry of Agriculture and Forestry), Karin Hjerpe and Magnus Bång (Swedish Board of Agriculture), and Kristin Sørheim (Bioforsk).

Our gratitude also extends to Olav Randen, Nanna Cliffoth, Ole Færgeman, Leif Bach Jørgensen and Jette Hagesen for their contributions during the workshops, and to Salim Belyazid for leading the causal loop workshops. 


\section{Introduction}

\subsection{Scope}

The main focus will be to describe the greenhouse gas emissions, such as nitrous oxide, methane and carbon dioxide, and other pollution sources such as ammonia from the agricultural sector. We intend to look at emissions at country level, which also partly comprise emissions that arise from imported feed, food and other inputs.

The report will also identify common traits and differences in the agricultural sectors (in terms of production and import and export numbers), food production systems and partly consumption trends in Denmark, Finland, Norway and Sweden. Most of the findings in this report are based on data, information and experiences from these countries.

Given that all the countries, except for Norway, are part of the European Union, certain reference is made to the emission reductions regime and overall policy framework for the agricultural sector at EU level. The report will also take an integrated approach to agricultural systems and consumption patterns through partial causal loop diagrams (see chapter 5). The report also goes on to briefly describe the policy and regulatory framework applicable to the agricultural sector that may be relevant to control its greenhouse gas and ammonia emissions. Different bottlenecks and conflicts of interest that oppose a paradigm shift will also be covered. The scope of the report also includes an inventory of various technical, organisational and management measures that can very often also be taken at farm level. This report will not describe the climate impact of agriculture in detail nor how to take various adaptation measures. The focus is mainly on describing the status quo in emissions and describing paths towards more sustainable, climate-change-friendly agricultural and food systems that also take into account larger aims formulated at global level, such as combating starvation and addressing the negative consequences of globalisation in the agricultural sector. 


\subsection{Target groups}

The main target groups for this report and for this project are listed below, along with some of the main messages targeted at each of these groups:

- Policy makers: the report may contribute input that facilitates decision-making in terms of adopting enabling policy, legislation and incentive and support schemes.

- NGOs and civil society: the report may contribute to raising public awareness of the measures that can restrict greenhouse gas and air emissions from the agricultural sector and the environmental advantages of a less meat-focused Nordic diet.

- Farmers and farming associations: the report may inform and stimulate them to take steps towards moving towards more carbonneutral farming practices and highlight the value of exchanging information and experiences, as well as pooling resources.

- Technology developers: the report will provide information and valuable data to be translated into further innovation and development activities.

\subsection{Objectives of the report}

\subsubsection{Main problem and contextual reality}

Emissions from agriculture are still high, given the available technology and a number of legislative frameworks at EU and national level that aim to restrict the environmentally adverse impact of agricultural activities. Projections at international and national level indicate relatively small emission reductions in the coming years. It is clear that the agricultural sector's impact on climate and the environment through greenhouse gas emissions and other air pollutants will not be significantly reduced without action and incentives. Actions need to address interventions and improvements deriving from technology and machinery, the individual (farmer level) and through new methods and approaches. In the Nordic countries the environmental and climate impacts of agriculture are relatively well known, both at policy level and in the agricultural sector itself, except for emissions related to land use. There is generally a high awareness among people, including farmers, regarding the main sources 
of air pollution and greenhouse gas emissions. This problem is therefore being addressed at various levels and through various measures. There is a whole arsenal of measures that could be taken at sectoral as well as at farm level to reduce greenhouse gas and atmospheric emissions.

However, these are not always economically viable, especially not for smaller-scale farmers. Another important factor is that farmers generally feel that they are overregulated. Hence there is reason for caution to avoid excessive red tape. Instead more room could be made for incentives in the form of more awareness-raising, educational measures and the provision of subsidies (where not considered state aid under EU legislation) for installing certain emission-abating technology or other methods to curb greenhouse gas and other atmospheric emissions from the agricultural sector.

In any case, it is difficult to define one single solution for the agricultural sector in the Nordic countries. Firstly, the geological and climatic conditions vary. Secondly, the perception of the problem and the means to deal with it vary among the general public and farmers. Thirdly, production and food systems have their own variations. Thirdly, there are certain conflicts of interest that have to be addressed, which currently may be counterproductive to arriving at a more carbon-neutral agricultural sector. Fourthly, whereas three of the participating countries are members of the EU and fall under the CAP (the EU Common Agricultural Policy), Norway is not.

\subsubsection{Goals of the report}

The two overall goals of the project are firstly to present the status quo or baseline data and information regarding the Nordic agricultural sector, its greenhouse gas and ammonia emissions, the regulatory framework and support systems, and conflicts of interest. Secondly the report aims to describe paths towards an agricultural system that contributes to achieving the applicable climate targets set at international and national levels.

These two main goals are broken down under separate chapters where the sub-objectives are to:

- Highlight some common traits and discern differences in agricultural production and agricultural practices in a region which culturally, social and economically is very homogenous but has considerable geological and climatic differences (Chapter 2). 
- Establish the status quo in emissions. The report will analyse and compare trends in greenhouse gas and ammonia emissions in the Nordic countries with a view to discerning differences and common emission trends to better be able to provide recommendations for various measures (policy, legal, organisational, and technical) (Chapter 3).

- Briefly analyse various measures at policy or farm level designed to influence this sector's greenhouse gas and ammonia emissions. These measures are presented in an inventory and partly as more detailed case studies, to describe their objectives, way of working and their current and potential application in the participating countries. (Chapter 6).

- Provide a systems approach in agriculture that is suitable for Nordic conditions and can also be used in other regions. This systems approach is set out in Chapter 5 and is largely based on the discussions and materials produced during the project workshops. This systems approach also addresses food systems and consumption patterns.

- Provide an opportunity to learn from existing Nordic experiences of agricultural systems and practices that have the potential to reduce greenhouse gas and other atmospheric emissions.

\subsection{Methodology}

The methodology defining the structure and content of this report mainly consists of the following steps:

First the project partners defined the main aim and objectives, approach and content of the report through national workshops and working meetings. These workshops also defined the structure and content of the national reports, which feed into this report.

Secondly, the project partners each produced a national report describing the agricultural sector, and current and projected emissions. The information and data in these national progress reports mainly derive from national statistical agencies, other governmental sources, scientific papers and national reporting data within multinational agreements such as the Convention on Long-Range Transboundary Air Pollution and the Climate Convention.

Thirdly, the project partners contributed to the main components of the report and in particular reported the measures and practices that are common in their countries. The list of measures in Chapter 8 was 
selected from "the Guidance document on control techniques for preventing and abating ammonia" and various national sources. Three measures were selected for a more in-depth study, since they were believed to have potential but there was uncertainty regarding their limitations and side effects.

\subsection{Policy context}

A new European Union Common Agricultural Policy (CAP) for 2014-2020 was adopted in 2013. On the whole this provides an important foundation for agricultural policy in Denmark, together with limitations. The legislation, however, contains a large degree of flexibility for member states, for example, in the design of environmental subsidies. It is also possible for member states to have their own legislation that goes beyond EU law.

Norway, being the only non-EU member covered by this report, has its own agricultural policy.

In 1979 approximately thirty nations signed the Convention on Longrange Transboundary Air Pollution (LRTAP convention). Aimed initially at reducing the effects of acid rain through controlling emissions of sulphur, its scope was later widened to include nitrogen pollutants, volatile organic compounds and photochemical oxidants.

The Protocol to Abate Acidification, Eutrophication and Ground-level Ozone - also called the multi-effect protocol or the Gothenburg protocol, as it was formally adopted in Gothenburg, Sweden, in 1999 and entered into force in 2005. After some years of preparations and negotiations a revised Gothenburg protocol was adopted in May 2012.

The revised Gothenburg protocol includes binding, nationally differentiated emission reduction targets for several pollutants, including ammonia and fine particulate matter $\left(\mathrm{PM}_{2.5}\right)$ set as percentage emission reductions between the base year 2005 and the target year 2020 .

One core piece of EU air pollution legislation, the directive on National Emissions Ceilings (NEC) (2001/81/EC), is to a large extent an implementation of the Gothenburg Protocol in the EU member states. It is currently under revision and the proposal sets national Emissions Reduction Commitments (ERCs) for all member states with several steps towards 2030. It constitutes an important but inadequate step towards the achievement of the objectives of the 7th Environmental Action Pro- 
grammes (EAP): to reduce the critical load of air pollution, and to effectively protect human health against risks from air pollution. ${ }^{1}$ The proposal includes new targets for the four initial pollutants, including ammonia $\left(\mathrm{NH}_{3}\right)$. And it also for the first time includes limits for $\mathrm{PM}_{2.5}$ and methane $\left(\mathrm{CH}_{4}\right)$.

The Industrial Emissions directive (2010/75/EU) regulates the intensive rearing of pigs and poultry. This means that farms with more than 40,000 places for poultry, more than 2000 places for pigs (over $30 \mathrm{~kg}$ ) or 750 places for sows, are counted as licensable activities.

Greenhouse gases from agriculture (carbon dioxide, methane and nitrous oxide) are treated under the Climate Convention and emission levels specifically under the Kyoto Protocol.

In EU legislation most greenhouse gases from the agricultural sector are included under the Effort Sharing Decision, with binding annual greenhouse gas emission targets for member states for the period 2013-2020. Emissions from power stations and industrial plants, including some parts of the agricultural industry, are regulated under the EU Emission Trading System. Emissions from land use and land use change (LULUCF) are still not covered in EU legislation, though there are ambitions to include them under the Effort Sharing Decision. LULUCF is, however, included in the reporting and reduction obligations under the United Nations Framework Convention on Climate Change (UNFCCC) (as are the other emissions mentioned above).

${ }^{1}$ Decision No 1386 of the European Parliament and of the Council (20/11/13): paragraph 15 and section thematic priorities 1 number $28 \mathrm{~d}$. http://eur-lex.europa.eu/legal-content/EN/TXT/?uri=CELEX:32013D1386 


\section{Agriculture in the Nordic countries}

\subsection{Introduction}

In the Nordic countries there are ample common traits in agricultural structure and land uses, agricultural production, demographic conditions and the employment market, but there are also notable differences. To understand emission trends it is important to pinpoint those similarities and differences, to analyse their importance and to extract conclusions that can be used to define political action, propose various technical, organisational and awareness-raising measures, and to provide incentives that may affect trends and curb emissions and the climate change impact from agriculture.

\subsection{Agricultural structures and land uses}

\subsubsection{Denmark}

Danish agriculture occupied in 2012 approximately 2.7 million hectares representing approximately $62 \%$ of Denmark's total area. Since 1982, there has been a decline in the cultivated area of approximately $8 \%$.

An overall trend in Danish agriculture is that there are fewer and fewer, increasingly large farms. Within the past 30 years the number of farms has more than halved from just over 100,000 in 1982 to about 40,600 in 2012, out of which approximately $30 \%$ are full-time farms and 28,000 part-time farms. This development occurred in parallel with changes in farming methods towards increased mechanisation and specialisation justified by the demand of the agroindustrial complex for high productivity in order to maintain competitiveness in a global market.

The average size of a Danish farm has more than doubled since 1982, from just less than 30 hectares to about 66 ha in 2012. In the meantime, specialisation in livestock production has led to fewer but larger livestock. 


\subsubsection{Finland}

$7.6 \%$ of Finland's total land area is agricultural land. Agriculture in Finland has traditionally been predominantly based on a larger number of smaller family farms. The number of farms peaked in the early $1960 \mathrm{~s}$, but has since then dropped. The average arable land area per farm has increased, but the total number of animals has declined. In terms of pig farms these have also declined but with larger crews on each farm.

In Finland the ownership structure is quite fragmented and the fields are scattered, which increases the need for transportation between the farms. There are large contiguous arable areas only in southern Finland and Ostrobothnia along the rivers. Further north the average size of parcels is smaller and the distance between parcels increases.

\subsubsection{Norway}

Agricultural land covers 3.3\% (0.9 million hectares) of Norway's total land area. There is a great variation in climatic and natural conditions in Norway. In most areas Norwegian agriculture is characterised by many small and steep plots that are far apart and difficult to operate efficiently with modern machinery. The long distances between plots result in manure being transported thousands of kilometres each year. There has been a significant structural change in Norwegian agriculture during the last 30 years and the number of farms (approximately 44,000 in 2012) has dropped by half.

\subsubsection{Sweden}

Approximately 7\% (3 million hectares) of Sweden's land area is agricultural land, $60 \%$ of which is found in the south on Götaland and Svealand plains. There are around 71,000 farms in Sweden. Most of the farms are specialised so that their main income comes either from crop production or animal husbandry. Less than $10 \%$ have a relatively even distribution of income from both livestock and crop production. There is a general trend in the livestock sector towards fewer and larger herds. The number of farms with cattle has decreased greatly from the early 1900s, while the average herd size has increased. 


\subsection{Agricultural production}

\subsubsection{Denmark}

The annual yield in crop production now amounts to about 170 million crop units (equivalent to a feed value of 17 million tonnes of grain (2012), over half of cereal crops. Approximately $80 \%$ of plant production is used as feed for livestock (grain, beet, rape, maize, silage and meadows). $9 \%$ of the land is used for produce for human consumption in the form of cereals, potatoes, sugar beet and vegetables. The last $10 \%$ is used for industrial potatoes, rapeseed for biodiesel, grass seed, Christmas trees, or is fallow. Approximately $7 \%$ of the area is organic.

Milk production has decreased slightly since the introduction of the milk quota in 1984 and is currently at a total of approximately 4.5 million tonnes. Dairy herds, however, have been almost halved over the period, while the yield per cow has risen to almost double.

Pig production increased in number from around 9 million in 1990 to 12 million in 2012. This reflects the number of pigs at any time during the year. However, approximately 20 million pigs are slaughtered in Denmark per year and on a daily basis around 4,500 tons of pig meat is produced. In recent years there has been a change in the composition of the pig population, since more piglets are exported to feed outside Denmark. Between 2008 and 2012 exports of piglets have risen from 5.3 million to 9.2 million on a yearly basis, and the number of pigs slaughtered in Denmark has decreased. The relative proportion of sows has therefore increased (Jordbruget i Danmark, Danmarks Statistik, 2014 and Notat om økonomi i husdyrproduktion).

The distribution of different soil types and production forms is reflected in the livestock density in different parts of the country, which is highest in Northern and Western Jutland and lowest on Zealand. Zealand is characterised by a relatively larger share of crop production in general, however roughage production is the highest in Jutland.

\subsubsection{Finland}

In 2012 the production of cereal crops was 3.7 million tonnes. The most widely cultivated grains are oats and barley. The production of meat (beef, poultry and pork) has increased during the last two decades, from 338 million kilograms in 1990 to 383 million kilograms in 2012. However, the increase is almost entirely caused by the increase in poultry production, which has more than tripled during that time. The production of 
beef has decreased around 30\% and the production of pork has stayed roughly the same. At the same time the consumption of meat has increased by more than ten kilograms (16\%) per person per year, which has caused imports of meat to increase.

Due to climate and soil conditions, the production of cereals and specialty crops, as well as swine and poultry, is concentrated in southern and western Finland, and milk production and grassland in eastern and northern Finland.

\subsubsection{Norway}

The average herd size in milk production has risen and the production per cow has increased dramatically. At the same time beef production has experienced a sharp decline, which has led to an increase in imported beef. The same applies for grain production. The grain acreage has gone down from 1991 to 2012, leading to increased imports of grain. There has, on the other hand, been a great increase in the production of both pork and poultry, and their production has become strongly centralised in certain areas. All agricultural production has declined in terms of price to the farmer. The only exception is the production of local food, which has had a strong increase during the last couple of years, due to a growing demand for traditional local produce, the desire for traceability and food safety.

\subsubsection{Sweden}

The most common land use is ley farming and growing other forage, which took place on $38 \%$ of all agricultural land in 2012. The proportion of ley farming increases the further north you go in the country. In the most northerly counties, ley farming is almost the only form of cultivation. The next most common crop is grain, which was grown on 33\% of the area. Other agricultural crops, especially oilseeds, pulses, potatoes and sugar beets were grown on $9 \%$ of the land.

Permanent grasslands represent only $14 \%$ of the agricultural area. The remaining 5\% lay fallow. Approximately $14 \%$ of all agricultural land is used for organic farming.

The production of beef and pork has decreased in the past two decades, while there has been a great increase in the production of poultry meat. Production of lamb meat has also increased, but is still quite marginal in quantity compared to other types of meat. Dairy production has decreased, while egg production remains quite stable. 


\subsection{Jobs/employment}

\subsubsection{Denmark}

Out of about 40,600 farms (in 2012), approximately 12,000 were fulltime farms (where working hours are over 1,665 hours per year) and about 28,000 were part-time farms. Full-time farms accounted thus for approximately $30 \%$ of the farms.

In 2012, around 70,000 people were employed in agriculture, forestry and fishery, which is less than $3 \%$ of the total labour force in Denmark. $43 \%$ of those employed in agriculture, forestry and fishing are aged 50 or over and $15 \%$ are 67 or older. If one considers merely the group of self-employed within these sectors, $69 \%$ are aged 50 or over and $28 \%$ are 67 or older. This trend of rising age amongst the selfemployed partly reflects the fact that the land in Denmark has become so expensive and farms have become so large that younger farmers find it very difficult to get established. The Danish Government tries to encourage young farmers (up to age 40) to establish themselves on their own farm by giving extra financial support.

Due to the trend to export more piglets and a fall in the number of pigs reared in the country for slaughtering, the number of 54 Danish Crown pig slaughterhouses within Denmark has fallen from 54 in 1974 to 20 in 1980. Today there are two left. In addition, there are seven other slaughterhouses that slaughter more than 10,000 pigs/year. The Danish Crown has dismissed 7,100 employees during the last 10 years. In 2012, the company had 8,000 employees in Denmark and 15,000 abroad. Hence, the trend of exporting piglets goes hand in hand with Danish Crown moving more and more production and jobs overseas.

\subsubsection{Finland}

The agricultural sector employed 3.1\% of the labour force in Finland in 2012. In 2012 the statistical average age of a Finish farmer was 51. Since 1995 , the average age has risen by about three years. The percentage of farmers over the age of 55 has increased from $26 \%$ in 2001 to $39 \%$ in 2012. As in Norway, the government has put into place an incentive scheme to support young farmers. 


\subsubsection{Norway}

Statistics for 2013 show that about $2 \%$ of the Norwegian workforce is directly employed in agriculture, of which $54 \%$ are over the age of 50 . Time consumption figures for many of those who have their main income outside the farm often show that they also spend as many working hours on the farm as full-time workers in manufacturing. Although farmers on the largest farms get the largest proportion of their income from the farm, the majority will also have incomes from other employment (snow ploughing, lumberjacking, part-time teaching or nursing etc.). Part-time farms in Norway are a prerequisite to maintain a desired settlement pattern, maintain food production through the use of local and renewable resources, preserve the cultural landscape and welltended villages, and foster values that characterise rural Norway. Norway has introduced a renovation scheme for younger farmers.

\subsubsection{Sweden}

Agriculture employs less than 2\% of the labour force in Sweden. Almost $70 \%$ of the aging Swedish farmers are more than 50 years old. Many (35\%) of the farms require so few working hours that they are judged not to be a main source of income for their owners. Less than a quarter of all agriculture is deemed equivalent to a full-time job or more, and only a few thousand are deemed to be so large that they have employees. The Swedish government has also established an incentive scheme to make farming more attractive for young farmers.

\subsection{Imports/exports}

\subsubsection{Denmark}

Denmark has the potential to be self-sufficient in food and drink and to export some agricultural products. However, the picture is not very clear if we want to look at how many people Denmark actually sustains or how many people the country could sustain.

In economic terms, Denmark has a positive balance in figures related to agriculture. The value of the total imports of land-based crops and fish was DKK 528,924 million in 2012 while exports totalled DKK 614,675 million.

A more detailed inventory shows that imports of food products and live animals had a value of DKK 58,092 million and exports in the same 
category had a value of DKK 101,160 million; imports of beverages and tobacco had a value of DKK 6,662 million and the corresponding exports had a value of DKK 6,310 million; imports of animal and vegetable oils and waxes had a value of DKK 4,919 million and the corresponding exports had a value of DKK 3,933 . Hence, there is quite a large surplus in the import/export balance related to food products and live animals, while there are small deficits in the balances for beverages and tobacco and for animal and vegetable oils and waxes. The surplus in food products and live animals is largely associated with exports of relatively expensive meat and dairy products, which are very dependent on relatively cheap imported feed, of which Denmark imports around two million tonnes every year.

Both imports and exports have grown during the last 20 years, reflecting increased trade in the agricultural sector. There is an information gap regarding recent calculations showing the import/export balances for land-use related to imported and exported products.

\subsubsection{Finland}

As regards staple foods, self-sufficiency in the food market is high, estimated at $75 \%$ in 2008 . However, self-sufficiency decreased and the import of staple foods increased by roughly 5\% during 2003-2008 (Niemi et al., 2013, p. 35-36).

In 2011, domestic production of grains, pork, poultry meat, eggs and milk fats was $100 \%$ of domestic consumption. In the case of grains it varies in percentage from year to year depending on, among other things, the weather. Beef production was $83 \%$ of consumption and liquid-based dairy products amounted to $95 \%$ of consumption (Statistikcentralen, 2012, p. 165). The majority of livestock feed is of domestic origin. About half of the domestic grain crop and forage production as a whole is used to feed livestock in Finland (Tike 2014A). Finland is selfsufficient in feed grains, and exports oats and barley. Finland is not selfsufficient in oilseeds, which are used to produce edible oils and protein fodder (Niemi et al., 2013, p. 31.). The shortfall is covered by imports, mainly of rapeseed, canola meal and soybean meal (Agriculture and Forestry 2010, Chapter 2.2.2.).

In recent years the import of meat has increased and the export of meat decreased, especially for pork, but also for beef and poultry. Total imports of meat rose from 54.0 million kilograms in 2008 to 81.4 million kilograms in 2012. During the same time period exports of meat fell from 73.4 million kilograms in 2008 to 52.3 million kilograms in 2012. 
Even though Finland is quite self-sufficient in food production, agriculture in Finland depends on many inputs, such as fertilisers, fuel and implements, which are imported.

\subsubsection{Norway}

The Norwegian Directorate of Agriculture reports that imports of animal feed totalled 651,000 tonnes in 2014. In addition, there are imports of feed for fish (both of animal and plant origin) 1,450,000 tonnes.

Although Norway is self-sufficient in nitrogen fertilisers, input chemicals - mainly potassium and phosphorus - are imported.

Norway is currently about $35 \%$ self-sufficient when imports of animal feed are taken into account. Other imports mainly consist of beef 356.9 million $\mathrm{kg}$ in 2013. In the case of dairy products there are significant imports of cheese, but Norway also exports some. Other products that are imported include fruits, berries and vegetables. Norway exports a lot of fish. Pelagic fish (wild) is a net export, while in the case of farmed fish, numbers have varied in recent years. In some years Norway has been a net exporter, and in others a net importer.

\subsubsection{Sweden}

In most categories of agricultural products Sweden is a net importer (Figure 4). Above all, we can see an increase in net imports of meat, dairy and eggs over the past decade.

These are all food categories with high emissions of both airborne pollutants and greenhouse gases. The exceptions are cereals and tobacco. The latter may seem strange given that the cultivation of tobacco in Sweden is not particularly extensive. This is because Sweden imports cheap raw tobacco, which is processed and then exported with a higher value.

The production of imported inputs such as feed and fertiliser leads to emissions in the countries where they have been manufactured and are not included when Sweden reports to the UNFCCC.

The Swedish Board of Agriculture estimates that the 650,000 tonnes of feed that is imported causes emissions of approximately 0.28 million tonnes of $\mathrm{CO}_{2}$ equivalents per year during cultivation, processes and transportation (excluding land use change) (the Swedish Board of Agriculture, 2012).

The Swedish Board of Agriculture estimates that about threequarters of the mineral fertilisers used in Sweden are manufactured in 
Western Europe, with an emission factor of $3 \mathrm{~kg} \mathrm{CO}_{2} \mathrm{eq}$ per kg N, while the remaining mineral fertiliser is produced in Russia, with an emission factor of $8 \mathrm{~kg} \mathrm{CO}{ }_{2}$ eq per $\mathrm{kg} \mathrm{N}$. This means that the total emissions from nitrogen fertiliser are 0.68 million tonnes.

The Environment Protection Agency has estimated that about $60 \%$ of the greenhouse gas emissions caused by Swedish consumption take place overseas.

\subsection{Conclusions}

Whereas Norway, Finland and Sweden have a relatively small proportion of agricultural land (3-8\%) compared to the total land territory, Denmark is one of the most intensively cultivated countries in the world, with a share of $62 \%$. The reason for the lower agricultural land coverage in Norway is the challenging climatic and natural conditions in Norway, which make farming very difficult.

One common trend in all the countries is that there is a discernable reduction in the number of dairy herds, but a sharp increase in the performance per milk cow. In some countries, such as Norway, increasing imports of beef and grains are due to a sharp decline in local produce. In both Denmark and Norway, pig production has increased. In all of the countries a significant proportion of vegetable production is used as animal fodder. In Denmark and Finland this proportion is as high as $80 \%$.

Another common feature in the Nordic countries, is the significant reduction in the number of the farms along with a shift in farming methods towards a high degree of mechanisation and specialisation, which is perceived to be necessary to maintain competitiveness in a global market. In Denmark, the number of farms has halved within the last 30 years.

The countries also show a common trend toward fewer but larger crews in livestock farming. Hence, whereas the number of farms with cattle has decreased greatly from the early 1900s, the average herd size has increased.

Furthermore, there is an overall trend of declining beef meat production, which may give rise to an increased reliance on beef imports. However, in most of the Nordic countries the production of pork and poultry increased.

A common concern is the low employment rates in the agricultural sector and the demographic change with older farmers. The jobs that 
this sector provides are rarely full-time, which means that most people carrying out farming activities may have another profession or income.

Although this chapter has shown that there are many common traits and trends in the Nordic countries there are still some differences, which should also be kept in mind when formulating various policy and other technical measures to reduce the climate impact of the agricultural sector.

For instance in terms of agricultural structures and land uses one can generalise and draw comparison between the size and nature of farms in Finland and Norway, where the general pattern is for fewer, scattered farms, as a result of variations in climatic and natural conditions that pose a challenge to agriculture and the full use of modern machinery. Sweden and Finland, on the other hand, see the main agricultural activity on the plains where the farms normally specialise either in crop production or animal husbandry. Here the trend has been towards a reduction in the number of farms, and increases in the size of existing farms and average herd size. Furthermore, it seems crop production is the lowest in Norway, which results in considerable grain imports. In Sweden and Denmark, crop production is significant. 


\section{Agriculture, greenhouse gases and air pollutants}

\subsection{Overview of significant pollutants}

The quality of the air we breathe affects our health and our environment. Global warming alters the conditions for all ecosystems on earth, which are the basis for our economy and civilisation.

Emissions from agriculture give rise to both these problems. At the same time, agriculture is negatively affected by both air pollution and global warming. The most important pollutants are methane, nitrous oxide, carbon dioxide and ammonia.

The division into sectors (used when countries report their emissions to the United Nations Framework Convention on Climate Change, UNFCCC) implies that agricultural consumption of energy for e.g. transport and heating belongs to the "Energy Industry and Transport sector". The agriculture-related share for Land use, Land Use Change and Forestry (LULUCF) is listed within the LULUCF sector. Only methane and nitrous oxide emissions are listed under "Agriculture". When talking about agriculture's share of the greenhouse gas emission, contributions related to energy consumption and LULUCF are therefore often neglected.

Emissions of traditional air pollutants, such as ammonia, are reported to the Convention on Long-Range Transboundary Air Pollution (CLRTAP).

\subsubsection{Methane}

Methane is both a potent greenhouse gas and an air pollutant, since it is a precursor for ground-level ozone. Methane contributes to about $16 \%$ of global greenhouse gases (warming potential) each year and around $40 \%$ of these emissions can be attributed to livestock production. ${ }^{2,3}$

\footnotetext{
2 http://www.ipcc.ch/pdf/assessment-report/ar5/wg3/ipcc_wg3_ar5_summary-for-policymakers.pdf

${ }^{3}$ http://www.fao.org/docrep/018/i3437e/i3437e.pdf
} 
Most of the agricultural methane emissions globally and in the Nordic countries come from ruminants, since the gas is formed naturally during their digestive process. Another source of methane is when manure is broken down anaerobically.

\subsubsection{Nitrous oxide}

Nitrous oxide represents $6.2 \%$ of global greenhouse gas emissions. Most of the global nitrous oxide emissions can be attributed to the agricultural sector.

Nitrous oxide is produced when microorganisms break down and convert various nitrogen-containing compounds. The amount of nitrogen in the soil increases as a result of adding manure, mineral fertilisers, or growing nitrogen-fixing plants. This increases the risk of the formation of nitrous oxide.

Farmlands that are naturally rich in nitrogen, mostly land with a high share of organic matter (known as organic soils), can be significant sources of nitrous oxide whether extra nitrogen is added via nitrogen fertilisation or not. Similarly nitrous oxide is formed and emitted when handling and spreading manure. Production of mineral fertilisers is also the source of nitrous oxide emissions.

\subsubsection{Carbon dioxide}

Carbon dioxide is the most important greenhouse gas. Agricultural carbon dioxide emissions have two main origins. The first is the burning of fossil fuels, to meet the sector's requirements for energy and transport (This is reported under "Energy Industry and Transport" when reporting to the UNFCCC). The second is emitted when carbon stocks in soils and in the growing plants are reduced. On the other hand if carbon stocks increase, farmland will act as a sink for carbon dioxide.

Carbon is stored in the soil in the form of plant residues, or when manure or sewage sludge is applied to the soil. Part of the plant residues and the organic material in the manure decomposes into carbon dioxide, but some is stored in the soil in stable humus compounds without breaking down. The largest changes in soil carbon stocks occur when there is a change in land use. Carbon dioxide emissions from soil into the air occur, for example, when forest or grassland is cleared to create fields and the previously undisturbed soil surface is broken down as a result of tillage and exposed to oxygen and microorganisms (The changes in soilplant carbon stocks are reported in the LULUCF sector). 


\subsubsection{Ammonia}

Agriculture is the largest source of ammonia emissions. Most of it is emitted from manure in stalls, during manure storage and spreading. Ammonia losses also occur from manure from grazing animals and a small part of ammonia emissions from the spreading of mineral fertiliser. Ammonia emissions contribute to eutrophication, but also to some extent acidification and the formation of particles.

\subsubsection{Indirect emissions}

It is not only direct emissions that Nordic food production and consumption contribute to. There are also large indirect emissions arising from the import of animal feed, fertiliser and foodstuffs from other regions.

\subsection{Overview of national agricultural emissions}

\subsubsection{Denmark}

In 2012, agriculture represented approximately 19\% of Denmark's total emissions of 51.6 million tonnes (according to official calculations i.e. for nitrous oxide and methane), of which nitrous oxide made up 5.4 million tonnes $\mathrm{CO}_{2} \mathrm{e}$, equivalent to approximately $10 \%$ of the total emissions, and methane made up 4.2 million tonnes $\mathrm{CO}_{2} \mathrm{e}$, equivalent to approximately $8 \%$ of the total emissions.

The proportion is approximately $32 \%$ when both LULUCF and energy consumption are included. Agriculture's share of emissions in the LULUCF sector is 3.4 million tonnes $\mathrm{CO}_{2}$ equivalents, corresponding to around $7 \%$ of the total emissions, and the sector's contribution to $\mathrm{CO}_{2}$ emissions from transport, heating, etc., is approximately 3.5 million tonnes $\mathrm{CO}_{2}$ equivalents, also corresponding to around $7 \%$ of the total emissions.

Finally, one can then subtract emissions saved due to the production of biofuels as a substitute for fossil fuels, which total 2.4 million tonnes $\mathrm{CO}_{2}$ equivalents. The saved emissions correspond to almost $5 \%$ of Denmark's total emissions.

A calculation to summarise the emissions from agriculture can be stated as follows: $\mathrm{N}_{2} \mathrm{O}+\mathrm{CH}_{4}+\mathrm{LULUCF}+\mathrm{CO}_{2}$ (from energy consumption) - $\mathrm{CO}_{2}$ (from saved energy consumption) (all in million tonnes $\mathrm{CO}_{2} \mathrm{e}$ ) = $5.4+4.2+3.4+3.5-2.4=14.1$ million tonnes $\mathrm{CO}_{2} \mathrm{e}$. 
A fairly accurate estimation of agriculture's share of Denmark's total emissions can therefore be summarised as approximately $27 \%$.

Agricultural ammonia emissions totalled 73,000 tonnes in 2012, which represents $96 \%$ of total ammonia emissions.

\subsubsection{Finland}

In Finland, methane and nitrous oxide from the agricultural sector account for approximately $9 \%$ of the country's greenhouse gas emissions. In 2012 the emissions from agriculture were about 5.7 million tonnes of $\mathrm{CO}_{2}$ equivalents. Emissions from fermentation of livestock accounted for $27 \%$, emissions from manure about $12 \%$ and nitrous oxide emissions from soil $60 \%$ of the total agricultural emissions. Emissions declined by $12 \%$ between 1990 and 2011.

In Finland, emissions from cropland on organic soils are of significance, and LULUCF emissions amount to 6.0 million tonnes of $\mathrm{CO}_{2}$ equivalents a year, which is the highest of all the Nordic countries.

Energy and transport in the agricultural sector give rise to about 1.3 million tonnes of $\mathrm{CO}_{2}$.

Ammonia emissions from agriculture were 33.3 thousand tonnes in 2012, which is around $90 \%$ of the total ammonia emissions.

\subsubsection{Norway}

Methane and nitrous oxide emissions from agriculture account for approximately $8 \%$ of Norway's greenhouse gas emissions. LULUCF emissions were 2.1 million tonnes in 2012.

Ammonia emissions from agriculture were 24.7 thousand tonnes in 2012 , which was $92 \%$ of all ammonia emissions.

\subsubsection{Sweden}

Agricultural emissions of methane and nitrous oxide were 7.7 million tonnes $\mathrm{CO}_{2}$ equivalents in 2012 and accounted for about $13 \%$ of total greenhouse gas emissions. If emissions from energy use are included, the share rises to $15 \%$. LULUCF emissions were about 2.3 million tonnes.

Ammonia emissions from agriculture amounted to 44,000 tonnes in 2012 , which corresponds to $85 \%$ of all ammonia emissions. 
Table 2: Greenhouse gas emissions for 2012 (in million tons $\mathrm{CO}_{2} \mathrm{e}$ ) as reported to the UNFCCC. Note that the figure for energy also includes forestry and fisheries; and the share for agriculture will vary between countries

\begin{tabular}{llrrrr} 
Sector & Sub-sector & Denmark & Finland & Norway & Sweden \\
Agriculture & Enteric fermentation & 2.90 & 1.54 & 2.04 & 2.54 \\
& Manure management & 1.69 & 0.67 & 0.35 & 0.75 \\
& $N_{2}$ O from soils & 5.00 & 3.50 & 2.11 & 4.35 \\
& Total & 9.60 & 5.71 & 4.50 & 7.69 \\
& & & & & \\
LULUCF & Cropland & 2.96 & 5.63 & 1.80 & 2.02 \\
& Grassland & 0.55 & 0.33 & 0.31 & 0.29 \\
& Total & 3.51 & 5.96 & 2.11 & 2.31 \\
& Agriculture/forestry/fisheries & & & & \\
& Total GHG, excl. LULUCF & 2.17 & 1.54 & 2.09 & 1.56 \\
& Total GHG, incl. LULUCF & 51.64 & 60.97 & 52.73 & 57.60 \\
& & 50.80 & 35.11 & 26.06 & 22.19 \\
\hline
\end{tabular}

\subsection{Emissions per pollutant and country}

\subsubsection{Nitrous oxide}

\section{Denmark}

Nitrous oxide emissions from agriculture totalled 17.4 thousand tonnes in 2012 (DCE 2014a), which represents approximately 90\% of the total nitrous oxide emissions. This corresponds to 5.4 million carbon dioxide equivalents, which is approximately $10 \%$ of Denmark's total emissions of greenhouse gases.

The largest share of nitrous oxide emissions comes from agricultural land. This is largely due to applied nitrogen from fertilisers and manure and the associated nitrogen leaching, which has given and still gives rise to the greatest emissions (DCE48).

Between 1990 and 2003 there was a steady reduction in nitrous oxide emissions from agriculture (in total 30\%), but since 2003 emissions have remained at approximately the same level. The reduction can particularly be related to the lowering of nitrogen load standards and improved nitrogen utilisation for manure, which has resulted in reduced need for chemical fertilisers. A smaller proportion of the reduction is due to manure management and the use of nitrification inhibitors. Over the same period of years the agricultural area decreased by approximately $4 \%$, which has also limited the use of nitrogen fertiliser.

\section{Finland}

Agricultural emissions of nitrous oxide were about 12.7 thousand tonnes in 2012, which is approximately $60 \%$ of Finland's total nitrous oxide 
emissions. This is about 3.8 million tonnes of carbon dioxide equivalents and contributes to $6 \%$ of Finland's total greenhouse gas emissions.

Nitrous oxide emissions from cultivated land have decreased by more than $10 \%$ since 1990 . This decrease is partly due to the decreased use of nitrogen fertiliser. The increased area of organic soils in cultivation, by contrast, has led to increased emissions.

\section{Norway}

In 2012 the emissions of nitrous oxide from agriculture were 7.4 thousand tonnes, equivalent to 2.2 million tonnes of carbon dioxide equivalents. This corresponds to about $4 \%$ of total greenhouse gas emissions. Emissions have remained level since 1990.

Norway also has two plants that produce nitrogen fertilisers, which caused nitrogen emissions of 0.9 tonnes in 2012. However, only $14 \%$ of the fertilisers are used in Norwegian agriculture, while the rest is exported. There has been a sharp decrease in emissions during the last decade as a result of improvements in the production process.

\section{Sweden}

In 2012, nitrous oxide emissions from agriculture in Sweden totalled 16,000 tonnes, which is 4.8 million tonnes of carbon dioxide equivalents. This means that nitrous oxide from agriculture represents $9 \%$ of the total greenhouse gas emissions in Sweden.

Emissions have decreased by $17 \%$ since 1990 . This is due to both improved manure management and lower loads of nitrogen on arable land.

Figure 1: Nitrous oxide emissions (thousand tonnes) in 2012 (UNFCCC)

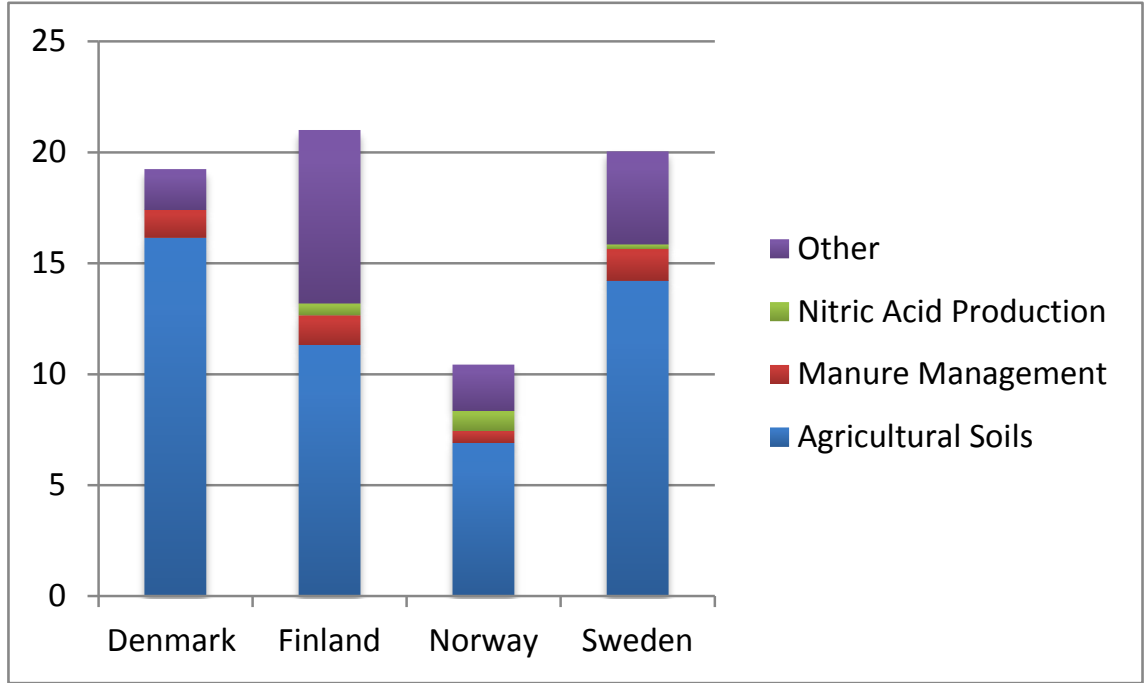


Figure 2: Methane emissions (thousand tonnes) in 2012

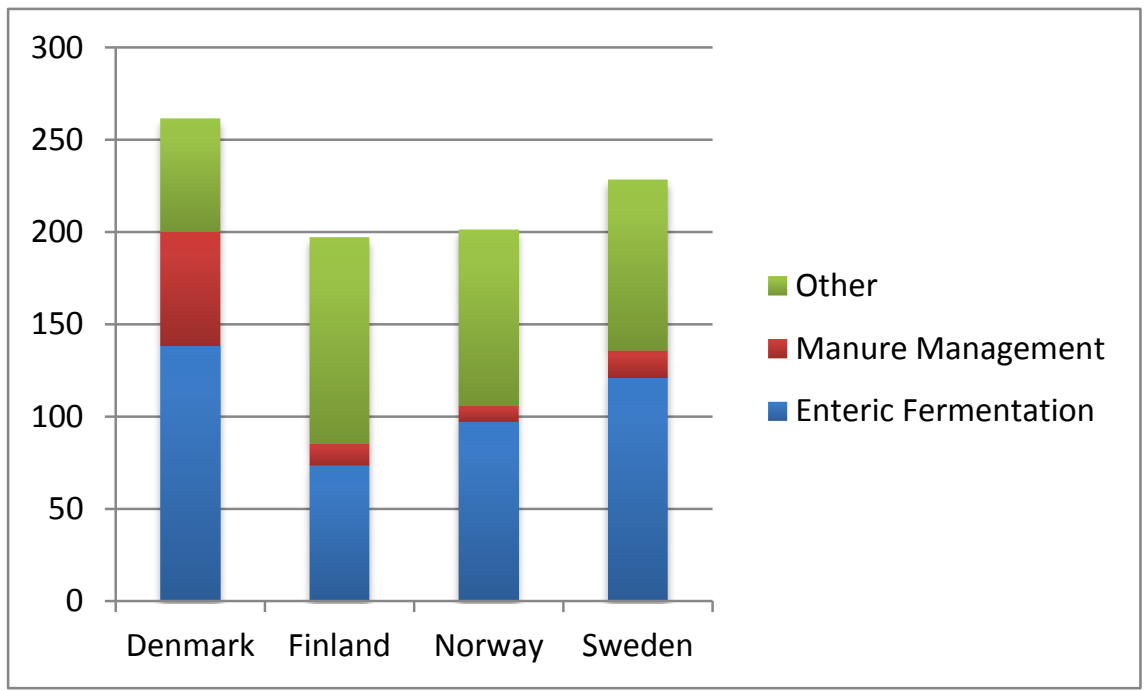

\subsubsection{Methane}

\section{Denmark}

Methane emissions from agriculture have for more than 20 years been approximately 200,000 tonnes. The emissions from ruminants have dropped slightly, but this decrease is offset by emissions from the handling of fertiliser that has increased due to the transition from solid manure to slurry.

In 2012, the emissions amounted to 200,100 tonnes, which accounted for almost $77 \%$ of the total methane emissions of approximately 261,500 tonnes. This corresponds to 4.2 million tonnes of carbon dioxide equivalents, or almost $8 \%$ of Denmark's total emissions of greenhouse gases.

\section{Finland}

In 2012, methane emissions from agriculture were around 85,000 tonnes, which is about $43 \%$ of all methane emissions. This is equal to 1.8 million tonnes of carbon dioxide equivalents, which was roughly one third of the agricultural sector's greenhouse gas emissions and around 3\% of Finland's total greenhouse gas emissions.

The number of cattle has decreased 30\% between 1990 and 2011, but methane emissions from digestion have not reduced correspondingly. Methane emissions from manure management have also increased due to changes in manure management practices. 


\section{Norway}

In 2012, methane emissions from agriculture were 106,000 tonnes, equivalent to 2.7 million tonnes of carbon dioxide. This is roughly half of all methane emissions in Norway and $5 \%$ of all greenhouse gas emissions.

The majority of methane emissions derive from ruminants, which constitute the single largest source of methane emissions (46\%). These emissions have fallen by $11 \%$ since 1990 , mainly due to the reduced number of animals.

\section{Sweden}

In 2012, methane emissions from agriculture were around 136,000 tonnes, equivalent to 3.4 million tonnes of carbon dioxide. This is about $60 \%$ of all methane emissions and $6 \%$ of the total greenhouse gas emissions.

Between 1990 and 2012, emissions have decreased by 10\%. This can be explained by the $12 \%$ decrease in the number of cattle in the same period.

\section{Figure 3: Nitrous oxide emissions (thousand tonnes) from agriculture} 1990-2012

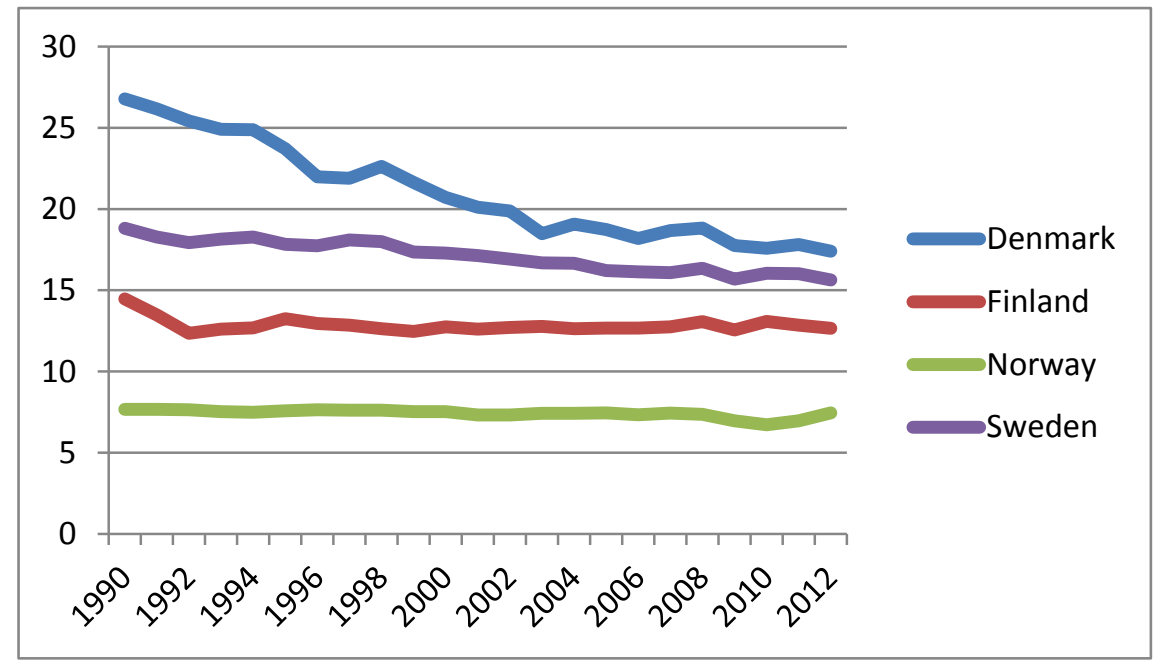


Figure 4: Methane from agriculture 1990-2012

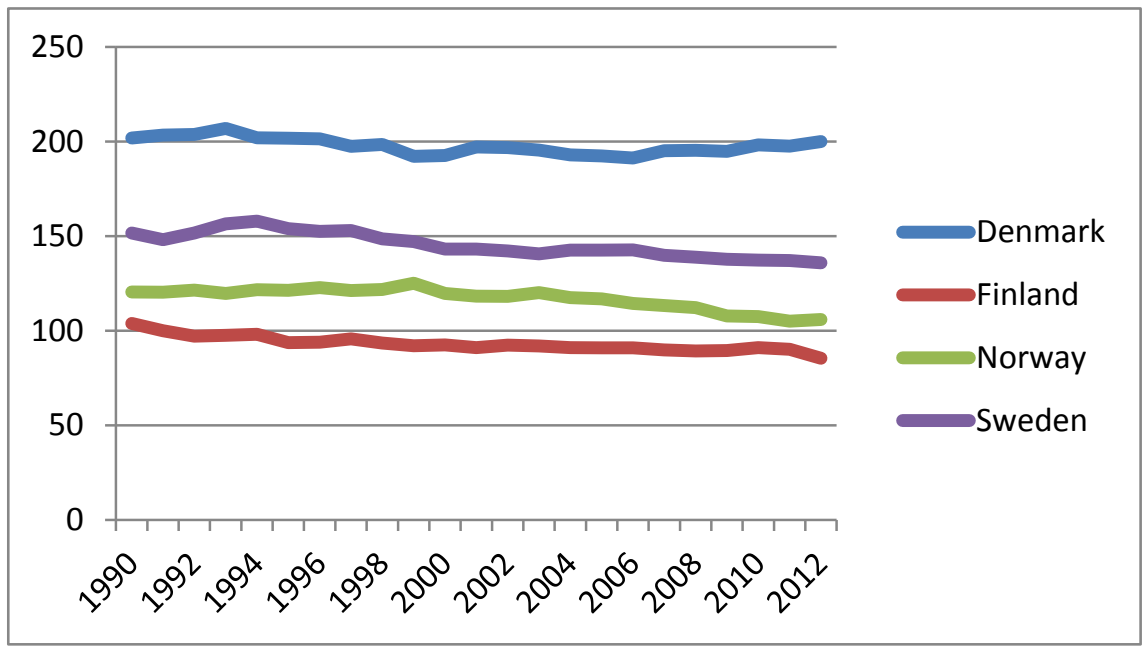

\subsubsection{Carbon dioxide from LULUCF}

\section{Denmark}

The LULUCF sector alternates from being a net sink and a net source of emissions. In 2012, LULUCF was a net sink, with carbon fixation representing the equivalent of $2 \%$ of total greenhouse gas emissions. In 2012, the forests fixed 4.4 million tonnes of $\mathrm{CO}_{2} \mathrm{e}$, while cultivated land released 3.0 million tonnes of $\mathrm{CO}_{2} \mathrm{e}$ and grassland released 0.55 million tonnes of $\mathrm{CO}_{2} \mathrm{e}$. Wetlands and urban areas released smaller amounts of $\mathrm{CO}_{2}$ (i.e. $<0.1$ million tonnes of $\mathrm{CO}_{2} \mathrm{e}$ ).

Emissions from arable land are mainly due to emissions from organic soils. Since 1990 there has been a decrease in the total carbon storage in mineral agricultural soils, although since 1990 it has been prohibited (with some exceptions) to burn straw in the fields. Areas classified as organic farmland are decreasing rapidly.

\section{Finland}

Emissions from agricultural land totalled 6.8 million tonnes of carbon dioxide equivalents in 2011. This figure includes 6 million tonnes from cultivated organic soils, 0.3 million tonnes from mineral soils, 0.2 million tonnes from liming of fields, 0.4 million tonnes from the clearing of woodland (biomass) to create more farmland, and 0.01 million tonnes of carbon dioxide equivalents due to nitrous oxide emissions from field clearing (Regina et al., 2014, p. 14).

Emissions from grasslands, which include abandoned farmland and grassland that is more than five years old, were estimated to be 0.2 mil- 
lion tonnes of carbon dioxide equivalents in 2011. This figure includes 0.8 million tonnes of emissions from organic soils and a carbon sink of 0.5 million tonnes of mineral soils (Regina et al., 2014, p. 13, 15). During the years 2000-2009 about 95,000 hectares of new arable land came into use. Of the cleared fields, about $30 \%$, or about 30,000 hectares were of organic soil type. Of Finland's arable land area, about $10 \%$ is peat soils (Niskanen and Lehtonen, 2014).

\section{Norway}

In 2012 the net emissions from arable land were 1.8 million tonnes of $\mathrm{CO}_{2}$ and from grasslands 0.3 million tonnes of $\mathrm{CO}_{2}$. Most of these emissions come from organic soils, which form $8-9 \%$ of the total area cultivated. This is land that was previously under water and is rich in organic matter that breaks down when it comes into contact with oxygen. The $\mathrm{CO}_{2}$ emissions from land use change were only minor. Nearly all of the land that was cultivated in 1990 was still farmland in 2012.

\section{Sweden}

Total estimated carbon emissions from agricultural land were 2.3 million tonnes of $\mathrm{CO}_{2}$ in 2012. There is, however, a large variation from year to year mainly due to large uncertainties in measuring small variations from such a large inventory. In some years, pastures have acted as a carbon sink.

Figure 5: LULUCF emissions (thousand tonnes of $\mathrm{CO}_{2}$ equivalents) from cropland and grassland in 2012

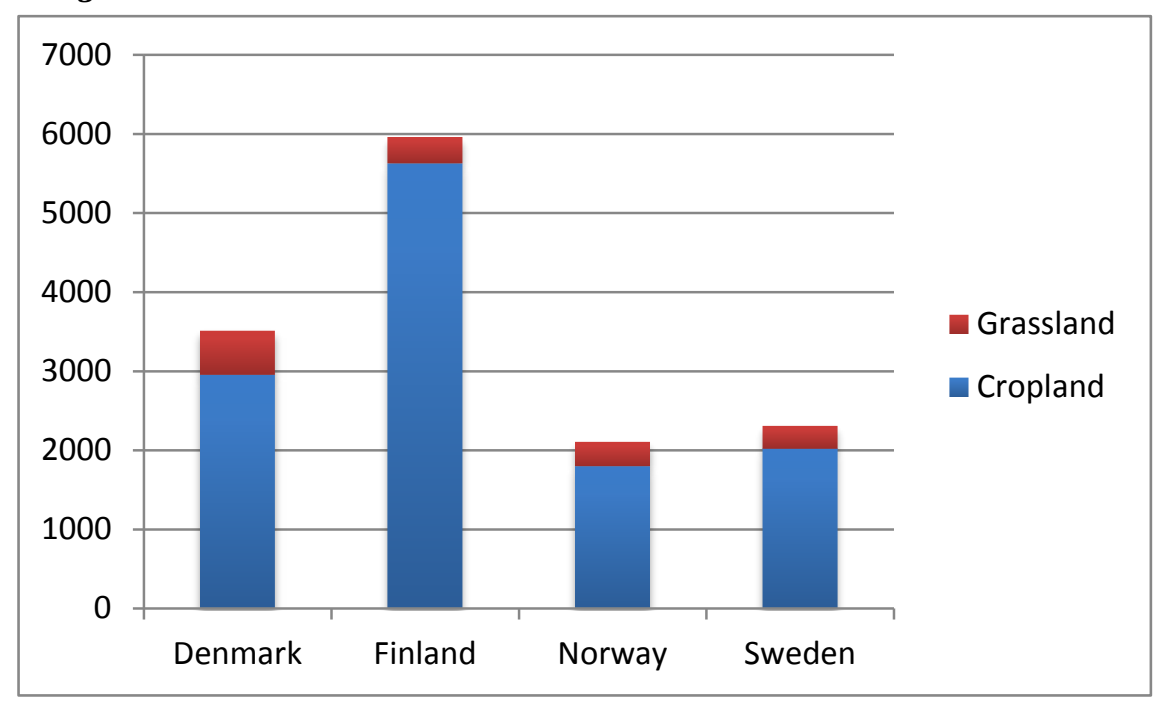


Figure 6: LULUCF emissions (thousand tonnes of $\mathrm{CO}_{2}$ equivalents) from cropland and grassland 1990-2012

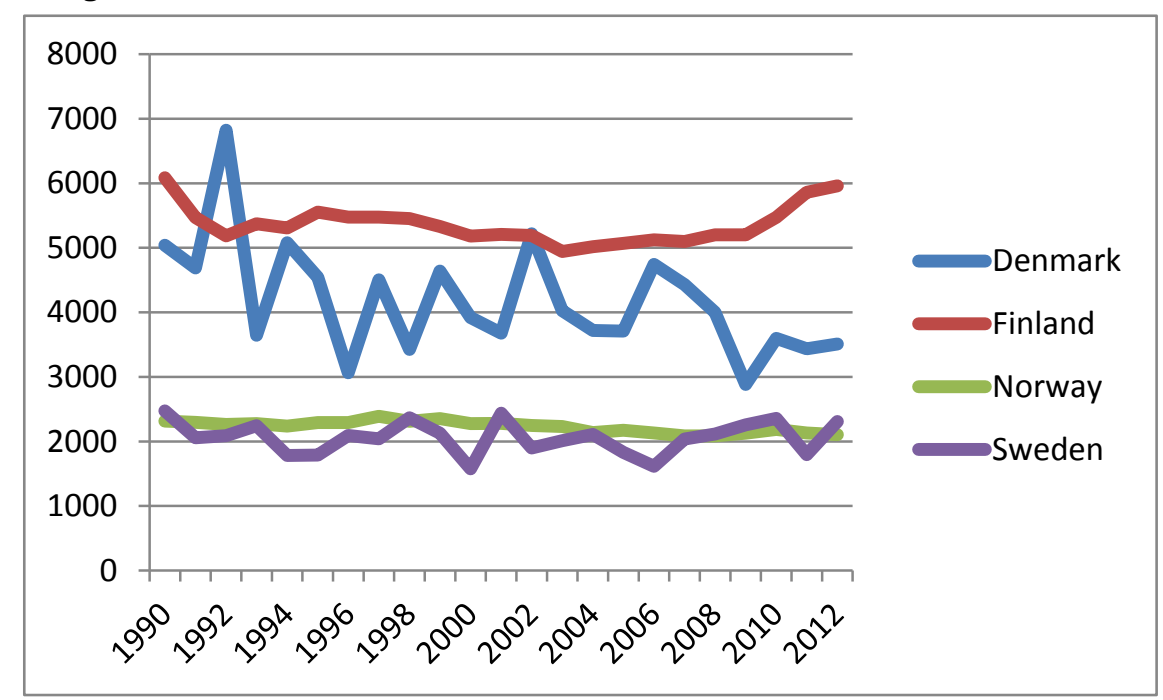

\subsubsection{Carbon dioxide from energy and transport}

\section{Denmark}

Emissions from energy use in the common sector of agriculture, forestry and fisheries were 2.17 million tonnes of $\mathrm{CO}_{2}$ in 2012. Since agriculture is a much more prominent industry in Denmark than fisheries and forestry it is likely that it also contributes to a majority of those emissions.

\section{Finland}

Finland reported to the UNFCCC 1.54 million tonnes of carbon dioxide equivalents from energy use within agriculture, forestry and fisheries in 2012. According to Statistics Finland, greenhouse gas emissions derived from energy use in the agricultural sector alone were 1.3 million tonnes of carbon dioxide equivalents in 2011.

\section{Norway}

Total emissions from energy use in agriculture, forestry and fisheries in 2012 were 2.1 million tonnes. However most of these emissions probably come from the other two sectors, forestry and fishery.

The use of petrol and diesel fuels in the agricultural sector is estimated by the agriculture and food ministry to result in 0.37 million tonnes of carbon dioxide per year. 


\section{Sweden}

The total reported emissions from agriculture, forestry and fisheries were 1.56 million tonnes in 2012. According to the Swedish Board of Agriculture, stationary energy accounted for about 0.4 million tonnes (of which $40 \%$ come from greenhouse cultivation). The use of fuel in mobile machinery is estimated to cause emissions of 0.8 million tonnes of carbon dioxide equivalents.

\subsubsection{Ammonia}

\section{Denmark}

Agriculture is the largest source of ammonia emissions, with a contribution of $96 \%$ to the total emissions. Most of the emissions are related to livestock production, where ammonia is released from manure in animal housing and from the storage and spreading of manure and from grazing animals.

Agricultural emissions of ammonia decreased from 124,000 tonnes in 1990 to 73,000 tonnes in 2012, representing a reduction of $41 \%$. This reduction was achieved through a series of policies over the period that were intended to reduce losses of nitrogen to the aquatic environment. A number of action plans have contributed to this: the NPO Action Plan (nitrogen, phosphorus and organic matter) in 1986; the Water Environment Plans in 1987, 1998 and 2004; the Action Plan for Sustainable Agriculture dating from 1991, and the Ammonia Action Plan of 2001. These plans have resulted in better nitrogen utilisation in animal production and better use of nitrogen in manure, along with a decrease in the use of fertilisers.

Following the Livestock Statute (BEK, 2002), ammonia treatment of straw has been banned since 1 August 2004. Also introduced is a ban on spreading manure on fields in winter, a ban on broadcast spreading of slurry and requirements to grow nitrogen-fixing crops.

\section{Finland}

In 2012, ammonia emissions from agriculture were 33,300 tonnes, which is around $90 \%$ of the total ammonia emissions. Cattle manure accounts for $60 \%$ of these emissions. The majority of these emissions come from the storage of manure in livestock housing and manure application on fields. Low emissions also arise from grazing (Grönroos, 2009, pp. 25-26). 
Over the past two decades there have been no significant changes in the amount of ammonia emissions from agriculture even though the numbers of animals have decreased. There is a close correlation between the amount of nitrogen excreted and the amount of milk produced.

\section{Norway}

Ammonia emissions from agriculture in 2012 totalled 24,700 tonnes, which was $92 \%$ of all ammonia emissions. More than $90 \%$ of these emissions are caused by manure. Between 1990 and 2008, emissions of ammonia increased by approximately $7 \%$ due to the increase in the usage of chemical fertilisers and increase in emissions from manure. Since then, emissions have decreased slightly.

\section{Sweden}

Agriculture is responsible for 44,000 tonnes of ammonia emissions, which corresponds to $85 \%$ of all ammonia emissions. Most of these emissions are from manure. Since 1995, agricultural emissions of ammonia have decreased by $25 \%$. This can mostly be explained by reduced livestock numbers, but also by improved manure handling.

Figure 7: Ammonia emissions (thousand tonnes) in 2012

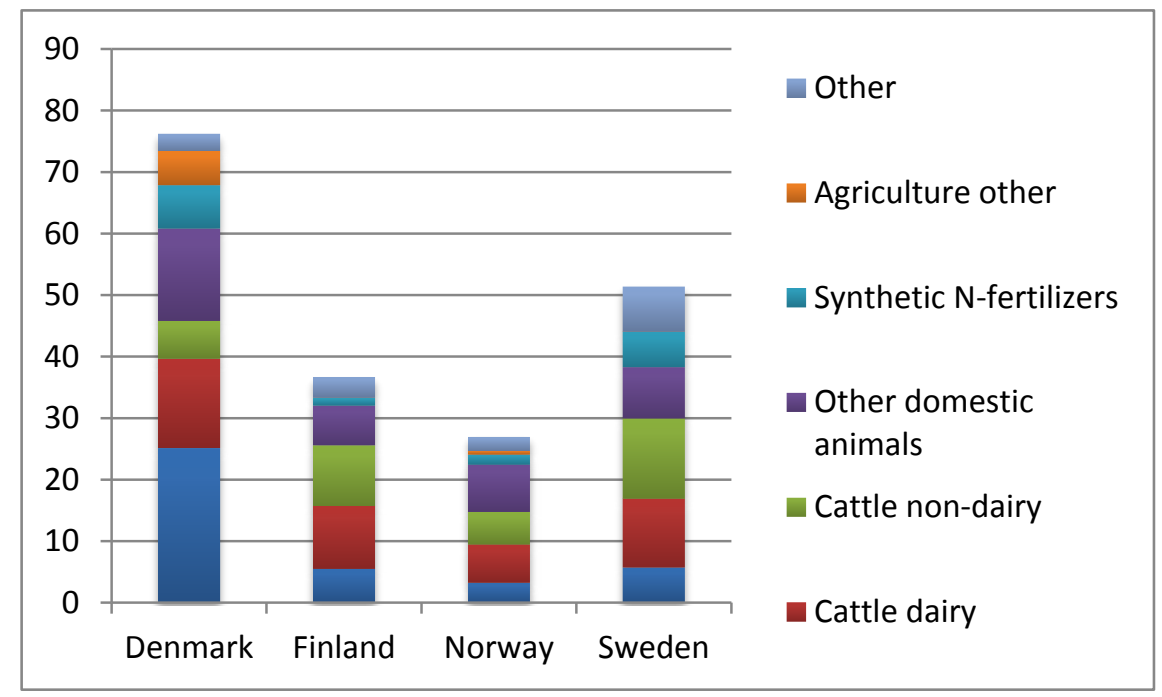


Figure 8: Ammonia emissions from agriculture 1990-2012

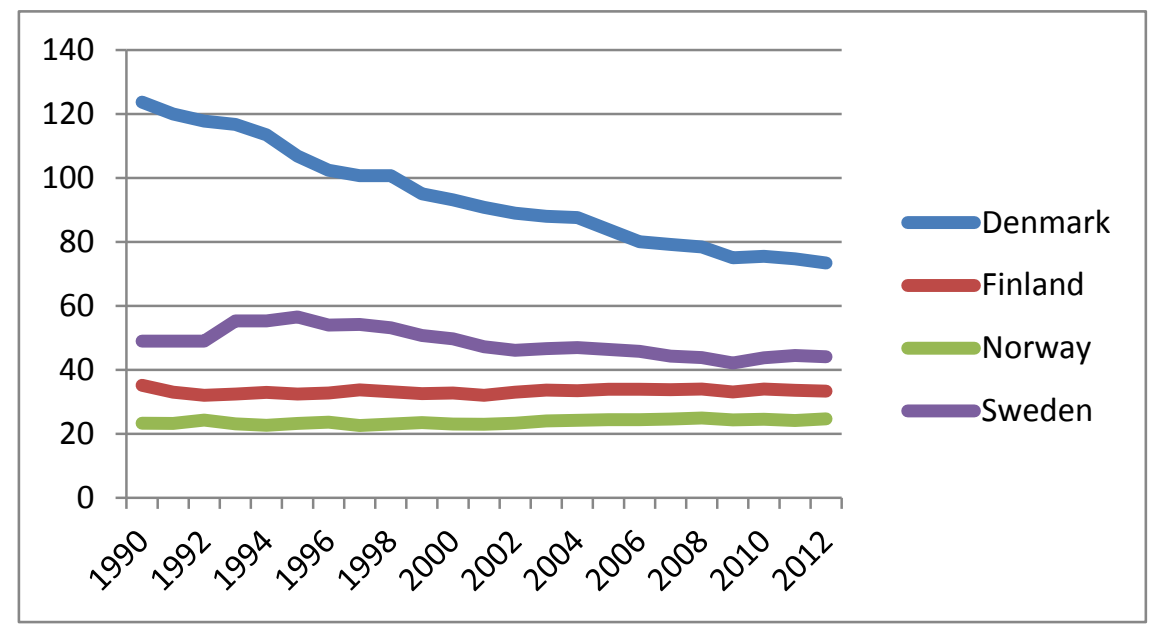

\subsection{Projected emissions}

\subsubsection{Denmark}

The largest future reductions to be achieved will be through continued improvements in manure management and thus increased/improved manure application, alongside the continued decline in the use of mineral fertilisers and falling emissions related to nitrogen leaching. In addition, several organic soils will be taken out of production:

- The decrease in nitrous oxide emissions from 1990 to 2010 is expected to continue but at a slower pace. The expected result of the projected initiatives would reduce nitrous oxide emissions by around $11 \%$, i.e. a decrease from 5.19 (million tonnes) $\mathrm{CO}_{2} \mathrm{e}$ in 2011 to $4.61 \mathrm{CO}_{2} \mathrm{e}$ in 2030 .

- Total methane emissions are expected to increase slightly until 2035. The underlying expectation is mainly based on three assumptions: The number of dairy cattle is expected to remain unchanged between 2013 and 2035. As a result of continuously increasing milk yields per cow this will lead to rising emissions from enteric digestion.

- Methane emissions from the handling of manure increased between 1990 and 2010 due to changes in storage systems towards more slurry-based systems. This trend is not expected to continue in the 
future, so it is likely that emissions from manure management will be almost unchanged by 2030 .

- The reduced emissions that result from digestion of manure to produce biogas are assumed to have a significant impact.

Source: DCE48.

\subsubsection{Finland}

Agricultural emissions will remain near current levels for the period 2011-2035. The area of organic farmland will continue to increase, but not as rapidly as in the early 2000s. Nitrogen fertilisation levels will rise if grain prices remain at a high level, which leads to higher emissions. Without any mitigation measures, emissions from the agricultural sector will rise from 5.9 million tonnes to 6.0 million tonnes by 2020 (Regina et al., 2014, pp. 17-18).

Emissions from the land use sector are expected to rise, unless special measures are taken. Under the baseline scenario, emissions will increase from the current level by 0.5 million tonnes by 2020 and 0.9 million tonnes by 2030 . The projected increase is primarily due to the fact that the area of farmland on organic soils is expected to increase. Moreover, the carbon stocks in mineral soils will change so that they become a source of emissions instead of being a sink (Regina et al., 2014, p. 18).

A forecast for 2050 does not reveal any remarkable changes in emissions (Grönroos et al., 2009, pp. 25-26).

\subsubsection{Norway}

There are currently no data on projections for these emissions from the relevant authorities.

\subsubsection{Sweden}

The Board of Agriculture has on behalf of the Environmental Protection Agency developed a reference scenario for agricultural emissions of greenhouse gases by 2050 . The scenario is based on the assumption that Sweden will produce just as much in the future as today, but that productivity increases by $0.5 \%$ each year. In other words the same amount of products will be produced in a smaller area and with fewer inputs. The assumed efficiency improvements would reduce emissions of methane and nitrous oxide by $8 \%$ between 2010 and 2050 . This is a 
slower rate of decline than we have seen in the past decade, which has mainly been caused by the reduced number of animals and reduced production (The Swedish Board of Agriculture, 2012 (a)).

The report points out that it is difficult to predict how large domestic production will be by 2050 . It might well continue to decline according to the current trend, or increase due to changes in world prices and the food needs of a large domestic population.

For ammonia, the Board of Agriculture has developed a reference scenario for 2030, which also assumes sustained production. It shows only marginal reductions. Between 2009 and 2030, the reduction in emissions will be less than 3\% (The Swedish Board of Agriculture, 2013).

\subsection{Conclusions}

The share of greenhouse gases (methane and nitrous oxide) from agriculture in the Nordic countries is 8 and 9\% in Norway and Finland respectively, whereas it is as high as 13\% in Sweden and 19\% in Denmark (based on UNFCCC reporting data). ${ }^{4}$ This share does not however reflect fossil fuel use linked to agricultural production, which under the reporting framework is accounted for under the heading "Energy Industry and Transport", nor does it reflect $\mathrm{CO}_{2}$ emissions related to land use.

Emissions from the production and transportation of imported inputs such as fertilisers and feedstuff are additional, and should be accounted for if one wants the full picture of agriculture's contribution to climate change in the Nordic countries, as should the emissions due to imports and exports of food.

Nitrous oxide emissions from agriculture represent as much as $90 \%$ of total emissions in Denmark, where the largest share of nitrous oxide emissions comes from agricultural land. The figure is smaller for Finland, where approximately $60 \%$ of Finland's nitrous oxide emissions come from agriculture. Since 1990, emissions of nitrous oxide have decreased in Denmark, Finland and Sweden, with the greatest drop of more than 30\% seen in Denmark. In all three countries the largest annual reductions were seen in the early 1990s. Emissions in Norway are the lowest, but have remained level for the past twenty years.

${ }^{4}$ If LULUCF and energy is included in the data for Denmark, the figure is $27 \%$. 
Methane emissions from agriculture since 1990 have dropped slightly in Finland, Norway and Sweden, mainly due to lower numbers of cattle. In Denmark, methane emissions have remained at the same level. Emission reductions from ruminants tend to be offset by increases in emissions due to the transition from solid manure to slurry, which is the case for Denmark and Finland.

In Denmark, carbon emissions related to land use are mainly from arable land, due to emissions from organic soils. Since 1990 there has been a decrease in the total carbon storage in mineral agricultural soils, although since 1990 it has been prohibited (with some exceptions) to burn straw in the fields.

Areas classified as organic farmland are decreasing rapidly. In Norway most of these carbon emissions come from organic soils, which form $8-9 \%$ of the total area cultivated. In Sweden, considerable variation from year to year is due to large uncertainties in measuring small variations from a large inventory. In Finland up to $30 \%$ of the new arable land areas cleared for cultivation between 2000 and 2009 were organic soils, which has increased the $\mathrm{N}_{2} \mathrm{O}$ emissions from arable land. In all of the countries, agriculture also releases carbon dioxide to meet their requirements for energy and transport.

The contribution from agriculture to total ammonia emissions is high in all four countries with the highest share in Denmark (96\%) and lowest in Sweden (85\%). Livestock manure contributes approximately $80-90 \%$ for all the countries. One interesting point is the difference in the reduction trends of ammonia. Whereas no significant change in ammonia emissions is noticeable in Finland (despite the falling number of livestock), emissions in Norway actually increased until 2008 due to the increase in the use of chemical fertilisers. Active policies in Denmark have resulted in significant emission reductions of $41 \%$ between 1990 and 2012. Sweden has also seen a 25\% decrease in emissions since 1995. 



\section{Manure regulation, incentives for emission control and conflicts of interests}

\subsection{Introduction}

As part of our analysis, we have looked at current legislation and incentives aimed at reducing emissions across the Nordic countries, where the emission problems are being addressed at various levels and with various measures.

There is a whole arsenal of measures that could be taken at sectoral as well as farm level to reduce greenhouse gas and air emissions. However, these are not always economically and practically viable. Furthermore, many of the technical measures are linked to an industrial agricultural system with large-scale animal production, which the working group has deemed an unsustainable system (see chapter 5). Large investments in measures to reduce emissions from this unsustainable system do not have the potential to even come near to a zero emission agricultural system - but may nevertheless lock the system into these unsustainable practices for decades. This poses a dilemma, as we do not want industrial agriculture to be deregulated, but on the other hand, public investments should not be directed towards measures that in practice will just keep the unsustainable system going.

Furthermore, there is a movement towards more sustainable farming practices and a more sustainable Nordic food consumption trend, although there is considerable resistance and various bottlenecks, especially associated with economic interests and conventional thinking, for instance favouring cheap agricultural products and/or lots of meat in the diet.

The transition we encourage will not be achieved easily, nor will it be achieved through legislative measures alone. Instead, more room should be made for incentives in the form of more awareness-raising, educational measures and the provision of dedicated subsidies for methods to 
curb greenhouse gas and other air emissions from the agricultural sector. These incentives should also tackle the need for greater selfsustainability in food production and consumption, minimising where possible imports of grains, soybeans and meat.

There are a number of conflicts of interests that need to be considered when designing incentives, regulations and other policy and technical measures that in one way or another impact the Nordic agricultural sector and its emissions. These conflicts of interests are presented at the end of the chapter. In our working group, however, we look for solutions that we find plausible in the long term, without trying to be balanced by only considering ideas that everyone can agree to, and without considering whether the industrial agricultural sector agrees to our proposals or whether they are considered "realistic" amongst farmers, politicians and the public.

\subsection{Legislative framework on manure regulation}

All the countries have rather similar legislative frameworks for manure regulation, with the most stringent regulations in Denmark, due to the need to reduce emissions from animal production that is highly polluting. The manure regulations do not necessarily restrict greenhouse gas emissions as their prime objective - this is rather one of many objectives behind the manure regulations. For instance biodiversity protection is another notable reason for the regulatory control. In some countries the applicable legislation is imposed at regional level and in others at national level. The Finish manure regulations are very detailed, whereas the Swedish regulations largely take into account regional differences and so-called sensitive areas, close to water bodies and coastlines. These regulations at least partially implement the EU directive on nitrates. ${ }^{5}$ For instance, in Denmark the EU Nitrates Directive is transposed by regulation of fertilisation, including fixed maximum nitrogen allocations and requirements regarding the use of manure, ${ }^{6}$ which lay down a number of rules for storage and application of manure, which aim to reduce emissions and leaching of nitrogen.

\footnotetext{
${ }^{5}$ Council Directive 91/676/EEC of 12 December 1991 concerning the protection of waters against pollution caused by nitrates from agricultural sources.

${ }^{6}$ Bekendtgørelse om erhvervsmæssigt dyrehold, husdyrgødning, ensilage m.v., 2013.
} 
Table 3: Manure regulations in the Nordic countries

\begin{tabular}{|c|c|c|c|c|}
\hline Regulations & Denmark & Finland & Norway & Sweden \\
\hline $\begin{array}{l}\text { Controls on } \\
\text { how and } \\
\text { when } \\
\text { manure } \\
\text { spreading is } \\
\text { allowed }\end{array}$ & $\begin{array}{l}\text { Animal manure } \\
\text { applied to non- } \\
\text { vegetated areas } \\
\text { must be tilled into } \\
\text { the soil as soon as } \\
\text { possible and within } \\
\text { six hours. } \\
\text { Spreading must not } \\
\text { be done in a way } \\
\text { which induces a risk } \\
\text { that the fertiliser } \\
\text { can be washed into } \\
\text { drains, streams or } \\
\text { lakes, for example } \\
\text { in the case of heavy } \\
\text { rain or thawing. } \\
\text { Application of liquid } \\
\text { manure and de- } \\
\text { gassed plant } \\
\text { biomass has to be } \\
\text { done by trailing } \\
\text { hoses, injection or } \\
\text { the like. } \\
\text { Application onto } \\
\text { black soil and } \\
\text { permanent grass } \\
\text { must be done by } \\
\text { injection or with } \\
\text { pre-treated slurry. } \\
\text { From harvest to } \\
1 \text { February, liquid } \\
\text { manure may only } \\
\text { be spread on } \\
\text { selected crop types } \\
\text { (fields with winter } \\
\text { rape and some } \\
\text { meadows). } \\
\text { The maximum } \\
\text { amount of manure } \\
\text { allowed to be } \\
\text { spread corresponds } \\
\text { to the manure from } \\
2.3 \text { livestock units } \\
\text { per hectare. }\end{array}$ & $\begin{array}{l}\text { Ban on spreading } \\
\text { manure in the } \\
\text { period } 1 \text { November } \\
\text { to } 30 \text { March. } \\
\text { Ban on spreading } \\
\text { nitrate fertilisers on } \\
\text { soil if it's covered } \\
\text { with snow or frost } \\
\text { or if it's saturated } \\
\text { with water. } \\
\text { The optimal time to } \\
\text { apply is in the } \\
\text { spring. } \\
\text { In the autumn } \\
\text { maximum amounts } \\
\text { apply. } \\
\text { Manure and organic } \\
\text { fertilisers applied on } \\
\text { the surface of the } \\
\text { soil must be incor- } \\
\text { porated into the soil } \\
\text { within } 24 \text { hours of } \\
\text { application with } \\
\text { some exceptions. } \\
\text { Slurry or urine } \\
\text { should be applied } \\
\text { through injection or } \\
\text { trailing shoe. } \\
\text { The manure and } \\
\text { organic fertilisers } \\
\text { applied on a field } \\
\text { are allowed to } \\
\text { contain a maximum } \\
\text { of } 170 \text { kg/ha/year } \\
\text { of total nitrogen. } \\
\text { Ban on surface } \\
\text { application of } \\
\text { manure if the slope } \\
\text { is more than } 15 \% . \\
\text { Ban on spreading } \\
\text { fertilisers closer } \\
\text { than } 5 \text { metres from } \\
\text { a water system }\end{array}$ & $\begin{array}{l}\text { Ban on spreading } \\
\text { manure on frozen } \\
\text { ground or snow } \\
\text { Dung should not be } \\
\text { spread during the } \\
\text { period } 1 \text { November } \\
\text { to } 15 \text { February. } \\
\text { Manure application } \\
\text { should mainly occur } \\
\text { during growing } \\
\text { season, i.e. from } \\
\text { spring to } 1 \text { Septem- } \\
\text { ber. After this date } \\
\text { all manure should } \\
\text { be incorporated } \\
\text { into the soil. }\end{array}$ & $\begin{array}{l}\text { On so-called sensi- } \\
\text { tive areas, which } \\
\text { roughly mean areas } \\
\text { near the coast } \\
\text { south of Stockholm, } \\
\text { it is not permitted } \\
\text { to spread more } \\
\text { manure than the } \\
\text { equivalent of } 170 \mathrm{~kg} \\
\text { of nitrogen per } \\
\text { hectare and year. } \\
\text { For winter oilseed } \\
\text { crops (that are } \\
\text { sown during the } \\
\text { autumn) there is a } \\
\text { maximum load of } \\
60 \text { kg of nitrogen } \\
\text { per hectare. } \\
\text { For other winter } \\
\text { crops there is a } \\
\text { maximum load of } \\
40 \text { kg of nitrogen. } \\
\text { In sensitive areas in } \\
\text { the country's most } \\
\text { southerly parts, } \\
\text { there are also } \\
\text { restrictions on } \\
\text { which spreading } \\
\text { techniques may be } \\
\text { used. (The Swedish } \\
\text { Board of Agricul- } \\
\text { ture, } 2014 \mathrm{c} \text {.) }\end{array}$ \\
\hline
\end{tabular}

${ }^{7}$ If the ground is unfrozen and dry and there's no risk of run-off or soil condensation, spreading manure is permissible until 15 November.

${ }^{8}$ The maximum amount for spreading solid manure is 30 tonnes per hectare, cattle slurry 20 tonnes per hectare, pig slurry 15 tonnes per hectare and poultry or fur animal manure 10 tonnes per hectare. The upper limit is $35 \mathrm{~kg}$ per hectare of soluble nitrogen, which must be weighed in when calculating the amounts of fertilisers for next spring. 


\begin{tabular}{|c|c|c|c|c|}
\hline Regulations & Denmark & Finland & Norway & Sweden \\
\hline $\begin{array}{l}\text { Require- } \\
\text { ments for } \\
\text { storage and } \\
\text { use }\end{array}$ & $\begin{array}{l}\text { Rules for slurry as } \\
\text { solid manure: } \\
\text { The capacity should } \\
\text { normally corre- } \\
\text { spond to at least } \\
\text { nine months' supply } \\
\text { of manure/dung. } \\
\text { Slurry containers } \\
\text { must not be placed } \\
\text { closer than } 100 \\
\text { metres to open } \\
\text { streams and lakes } \\
\text { (larger than } 100 \text { m²). } \\
\text { Containers shall be } \\
\text { made of durable } \\
\text { materials, which } \\
\text { can resist penetra- } \\
\text { tion of moisture. } \\
\text { Slurry tanks must be } \\
\text { strong enough to } \\
\text { withstand impact } \\
\text { from machines. } \\
\text { Slurry tanks must be } \\
\text { covered with either: } \\
\text { 1) a fixed cover } \\
\text { 2) a natural floating } \\
\text { layer. } \\
\text { If not covered, } \\
\text { ammonia-reducing } \\
\text { technology should } \\
\text { be applied. } \\
\text { Dunghill sites must } \\
\text { comply with re- } \\
\text { quirements regard- } \\
\text { ing material. }\end{array}$ & $\begin{array}{l}\text { Storage must } \\
\text { accommodate } 12 \\
\text { months' worth of } \\
\text { manure, apart from } \\
\text { the manure that is } \\
\text { left on the pasture } \\
\text { during grazing } \\
\text { season. } \\
\text { Storage must be } \\
\text { watertight and must } \\
\text { not pose a threat to } \\
\text { ground water. }\end{array}$ & $\begin{array}{l}\text { Each farm must } \\
\text { have adequate area } \\
\text { to spread the } \\
\text { manure on (alt- } \\
\text { hough no require- } \\
\text { ments regarding } \\
\text { allowed distance } \\
\text { from the manure } \\
\text { storage to the area). } \\
\text { All farms must have } \\
\text { storage capacity for } \\
8 \text { months. }\end{array}$ & $\begin{array}{l}\text { All livestock farms } \\
\text { must have sufficient } \\
\text { manure storage in } \\
\text { order to avoid } \\
\text { spreading manure } \\
\text { during inappropri- } \\
\text { ate times of the } \\
\text { year. } \\
\text { The number of } \\
\text { animals and where } \\
\text { in the country the } \\
\text { farm is located } \\
\text { determine the size } \\
\text { (6 to } 10 \text { months' } \\
\text { storage capacity). } \\
\text { In southern Sweden } \\
\text { there are also } \\
\text { requirements for } \\
\text { coverage of slurry } \\
\text { and urine tanks, } \\
\text { with a floating cover } \\
\text { or equivalent. } \\
\text { There are also } \\
\text { geographically } \\
\text { specific rules for } \\
\text { when you can } \\
\text { spread the manure } \\
\text { and how quickly it } \\
\text { should be incorpo- } \\
\text { rated into the soil. } \\
\text { (The Swedish Board } \\
\text { of Agriculture } \\
2014 \text { c.) }\end{array}$ \\
\hline $\begin{array}{l}\text { Other } \\
\text { require- } \\
\text { ments }\end{array}$ & $\begin{array}{l}\text { Nitrogen standards } \\
\text { for various crops as } \\
\text { well as require- } \\
\text { ments on plant } \\
\text { cover/cover crops } \\
\text { that can absorb } \\
\text { excess nitrogen. }^{11}\end{array}$ & $\begin{array}{l}\text { Every five years the } \\
\text { farmer must con- } \\
\text { duct a manure } \\
\text { analysis determin- } \\
\text { ing the soluble } \\
\text { nitrogen, total } \\
\text { nitrogen and total } \\
\text { phosphorus con- } \\
\text { tents in the manure. } \\
\text { A } 30-100 \text { metre } \\
\text { wide non-fertilised } \\
\text { zone must be left } \\
\text { around wells and } \\
\text { springs suitable as } \\
\text { household water } \\
\text { supply. }\end{array}$ & & \\
\hline
\end{tabular}

${ }_{9}^{9}$ Some slurry tanks must always have a fixed cover. This applies if they are built closer than 300 metres from neighbouring dwellings or certain types of habitats.

${ }^{10}$ There are some exceptions to the storage size, for example if farmers own shared storage facilities.

11 Bekendtgørelse af lov om jordbrugets anvendelse af gødning og om plantedække, 2013). 


\subsection{Current measures and incentives}

\subsubsection{Changing food consumption patterns and information initiatives}

In recent decades, Nordic consumption of food has changed somewhat. For instance, in the case of Finland the consumption of cereals has risen per person per year from $74.2 \mathrm{~kg}$ in 1990 to $78.8 \mathrm{~kg}$ in 2011. Finland also saw an increase of about 10 kilos/year in meat consumption. Meat consumption in most of the Nordic countries has shifted from less beef towards more poultry and pork. However, in Sweden all kinds of meat consumption have almost doubled since 1990: beef (+87per cent), poultry $(+246 \%)$, and pork $(+53 \%) .12$

Many countries realise that consumption patterns are affected by awareness-raising and public information campaigns. On 19 November 2013 the National Food Agency (NFA) of Sweden presented its "environmentally smart" dietary guidelines:

- "Eat less meat, choose vegetable options instead". Try to replace one or two meals of beef, lamb, pork or chicken every week with vegetarian meals, or eat smaller portions of meat.

- Choose fish from sustainable stocks or farmed in a sustainable way, for example certified fish.

- Choose fruits and vegetables that store well, for example field vegetables, and choose perishable fruits and vegetables when they are in season.

- Eat less sweets, cakes, cookies and snacks - they have an impact on the environment but their nutritional contribution is low.

- Minimise food waste - store food properly, plan your purchases and use the leftovers!

Source: The National Food Agency 2013.

Other Swedish initiatives include the Swedish Seal (a subsidiary of the Federation of Swedish Farmers) and KRAV (a body for labelling organic farming), which developed a climate certification scheme for Swedish food

$12 \mathrm{http}: / /$ www.jordbruksverket.se/webdav/files/SJV/Amnesomraden/Statistik,\%20fakta/Livsmedel /J044SM1401/J044SM1401/J044SM1401_tabeller4.htm 
between 2007 and 2012 in collaboration with a small number of food manufacturers. The label requirements include energy usage, nutrient balance and slaughter age. The largest reductions in per cent among those certified have been among greenhouse growers, while the reduction potential for a farm with cattle is much lower (Klimatmärkning, 2014).

In Norway, health and environmental authorities have for some time given guidelines for a healthier and more environmentally sustainable consumption policy. For instance, there are guidelines to eat more white meat instead of red meat. However, the import of meat that has been treated with antibiotics that can lead to antibiotic-resistant bacteria has been the subject of public campaigns and media attention. In line with the recommendations of FAO towards a new global agricultural policy, more attention should be given to self-sustaining agricultural and food systems, that rely more or less on imported products. Farming systems that are less reliant on imported products may also help to combat global starvation and poverty. In this context it is important to keep in mind the various conflicts that aim to define farming systems and the proportion of imported farming products.

\subsubsection{Support schemes - some tools for inspiration}

Agri-environmental measures under the EU Rural Development Programme may contribute to controlling emissions from agriculture and also in affecting consumption patterns, especially through various farm payment schemes and other requirements in terms of areas that may not be converted to farmland for environmental and nature protection reasons.

\subsubsection{EU level}

The new Rural Development Programmes for the period up to 2020 for Finland and Denmark were approved by the commission in late 2014 and early 2015. The rural development programme for Sweden was still not finalised in March 2015. Under the EU system, the bulk of agricultural support is channelled through the single farm payment scheme. Until 2014 this was not subject to any environmental requirements apart from cross-compliance, which basically means that farms must comply with current environmental laws in order to qualify for the payment. From 2014, farms must meet three very basic environmental requirements. One of them, the requirement not to plough or convert grasslands in Natura 2000 and other designated areas, may have an impact on car- 
bon sequestration. Until 2005, direct payments in the EU were related to the number of animal units on a farm. This created an incentive to rear more animals. This incentive disappeared when subsidies were decoupled. In most parts of Europe, the number of animals decreased and thus also emissions.

\subsubsection{Nordic level}

In Finland, a set of agri-environmental measures was established as part of the rural development programme for mainland Finland for the period 2003-2007.13 This programme contained several measures affecting emissions. The measured were updated for the new period 2014-2020.

\begin{tabular}{|c|c|}
\hline Measure & Objectives in terms of air emissions \\
\hline Well-balanced use of fertilisers. & Reduced emissions of nitrous oxide. \\
\hline $\begin{array}{l}\text { Recycling nutrients and organic materials (between } \\
\text { farms specialised either in crops or animals). }\end{array}$ & $\begin{array}{l}\text { Reducing greenhouse gas emissions by improving the } \\
\text { quality of soil. }\end{array}$ \\
\hline Spreading of slurry in fields. & Reducing ammonia emissions. \\
\hline Management of run-offs. & $\begin{array}{l}\text { Reduced greenhouse gas emissions, especially from } \\
\text { organic lands. }\end{array}$ \\
\hline Cultivation of grassland. & Reduced carbon dioxide emissions from arable land. \\
\hline Land cover in winter. & $\begin{array}{l}\text { Prevents carbon stocks in soil from being consumed, } \\
\text { promoting the binding of carbon in the soil. }\end{array}$ \\
\hline
\end{tabular}

In Sweden, among the measures that could provide environmental support under the Rural Development Programme (2007-2013), several impact emissions (Table 2).

13 Åland has its own rural development programme. 
In Norway, the State and agricultural organisations negotiate annually on pricing and support. Cooperative organisations have a market responsibility to pay similar commodity prices across the country. Subsidies are based on acreage, number of animals, grazed pastures, hired help, different cultural values and modes of operation as well as quantity produced. The first units are given higher subsidies but the trend in recent years has shifted to stimulate increased production. This has the effect that support operates to a lesser extent as a regional policy instrument, but rather as a means of increasing the volume and thus the concentration of production in a few favourable areas in Norway.

Finland has also established a Farm Energy Programme - a voluntary programme for farms. The main idea is that a consultant first tailors an energy plan for participating farms describing measures that save energy for the farms. Farms with low energy consumption can carry out assessments themselves using checklists (More information at: www.mavi.fi).

In Denmark, the Green Development and Demonstration Programme (GUDP) is a support programme under the Danish AgriFish Agency, which presents the programme as follows: "GDDP is a modern support system addressing some of the key challenges for the food sector and the whole society. The challenge is to create a greater sustainability, while solving some of the climate and environmental problems facing society while at the same time the economy is improving, so that the food sector continuously can generate growth in Denmark and secure jobs". (However, so far the Agency has been very traditional in their allocation of financial support, although there is - in our opinion - a huge need for more innovation). Organic farmers receive extra subsidies. 
In addition to the legislative measures described above, there are a number of support schemes aimed directly towards reducing leaching of nitrogen, e.g.:

- Support for the establishment of wetlands where fertilising is not allowed (for a period of at least 5 years).

- Supplementary support for reduced nitrogen inputs on farms that already receive subsidies for organic farming.

- Support scheme for biogas plants and production.

\subsubsection{Tax on fertilisers and pesticides}

Between 1984 and 2010 there was a tax on fertiliser in Sweden. When it was abolished the rate was SEK 1.80 per kilogram of nitrogen. The tax also included a component for the cadmium content of the fertiliser.

The argument for abolishing the tax was that Swedish agricultural products were disadvantaged, since no other EU country had this kind of tax. The Swedish Agricultural Board estimates that the abolished tax has led to increased nitrous oxide emissions equivalent to 0.07 million tonnes of $\mathrm{CO}_{2}$ equivalent per year (The Swedish Board of Agriculture, 2012 (a)).

Denmark also has a tax on nitrogen fertilisers but only for use of the fertiliser outside agriculture and forestry, as these sectoral uses are regulated through other legislation.

In Denmark the use of pesticides is taxed. The tax is graduated with respect to the toxicity of the active ingredients. In order to protect water, nature and health the current government has a strategy with the goal to reduce pesticide use by $40 \%$ by the end of 2015 .

\subsection{Conflicts of interests - some examples}

Efforts to reduce emissions from agriculture may be in conflict with other interests, such as:

- Animal welfare.

- Biodiversity and cultural landscapes.

- Farmers' income.

- Cheap food.

- Free trade. 
- With those who earn a lot of money on the current system (transparency).

- Land use.

- Other challenges of global agriculture.

\subsubsection{Animal welfare}

The area for manure littering is usually greater in free-range (indoor) systems and the manure is in a solid form, which has different properties to liquid manure. The solid manure is considered very beneficial for the soil structure.

Slotted floors are an efficient way to collect animal manure, but can cause injuries to animals' feet.

A short lifecycle for livestock will lead to lower greenhouse gas emissions per kilogram of product, however breeding for fast growth may cause health problems for animals.

Keeping animals indoors all year round makes it possible to use scrubbers and filters to clean the air from emissions. It also provides the possibility to collect all the manure, while free range gives a more uneven distribution.

\subsubsection{Biodiversity and cultural landscape}

Grazing animals, especially on permanent grasslands, are of great importance for biodiversity and increase the potential for soil carbon sequestration. Open pastures also have cultural and aesthetic values.

It is debated whether these systems are more or less efficient when it comes to greenhouse gas emissions per kilogram of product.

Interventions to decrease consumption of animal products could lead to less areas being grazed, if not combined with other interventions.

\subsubsection{Farmers'income}

Technical systems that lead to lower emissions require investments in machinery and housing. Many farmers in the Nordic countries are already struggling to survive economically. New minimum standards might be the straw that breaks the camel's back and lead to the decision to close a farm. In highly productive areas this often leads to the farm being bought by the neighbouring farm, which contributes to the trend towards ever-larger units. In less productive areas, it usually means that agricultural land will be converted into forest. 


\subsubsection{Land use}

It is debated whether low-input ecological farming methods are viable farming systems, as more land is used to produce a unit of food (e.g. a kilo of grain or meat, or a litre of milk) compared with intensive farming systems that have high inputs of fertiliser, pesticides and energy. On the other hand, the low-input systems may preserve biodiversity, water and landscapes, and take more care of animals' welfare. Hence, ecological farming systems require diets based on relatively more vegetable and less animal products.

\section{Other challenges of global agriculture}

The main purpose of agriculture is to produce enough healthy food for the world's population. In a situation where the number of people on Earth who are starving has in the last 30 years remained stable between 800 million and 1 billion in spite of the so-called green revolution, it is necessary to take a close look at how production takes place, where it takes place, and how food is distributed. The need for sustainable food production becomes even more apparent when one assumes that for every degree that the temperature rises around the globe, crop production decreases by $10 \%$.

In addition, agriculture contributes in a multifunctional way to the creation of vibrant and well-managed communities and provides a basis for well-being, cultural landscape, biodiversity and local wealth creation.

Proposals for climate measures in Nordic agriculture should not be isolated from the perspective of the world food situation. When 20,000-30,000 people die daily from hunger and hunger-related diseases, including 14,000 children under 5 years of age, it is a situation that must be taken into account when the Scandinavian countries consider measures in its food policy. Hunger and poverty are a major cause of unrest, war and subsequent refugee flow to Europe. It is therefore clear that one must have a broader focus than just to produce enough food; a sustainability and distribution must also be taken into account.

The recommendations of the Food and Agriculture Organization (FAO) should be given considerable weight. The UN's Special Rapporteur on the right to food (2008-2014), Olivier De Schutter says: "All countries must work to feed themselves! We must also be more aware of our diets, especially over the consumption of meat. So we must realize that industrial agriculture with large overuse of fertilizers and chemicals has reached an endpoint."

Food production and trade are regulated today by common international trade rules, where free trade is the main rule. Seen from the per- 
spective that there is enough food produced in the world, it must be concluded that these rules are unsuccessful in relation to reducing hunger and poverty as well as solving the world's climate challenges, to which agriculture contributes. It is against this background that De Schutter points to the need for new policy instruments.

La Via Campesina, a global smallholder movement that has over 200 million members, including small farmers, fishermen, landless agricultural workers, indigenous peoples and nomads, points to the same conditions and has launched the concept of Food Sovereignty as an alternative to industrial farming and free trade. Food Sovereignty means that every nation has the right to decide its own agricultural and food policy, to implement the regulatory measures, support systems and protective measures that they find necessary and to decide which agricultural products they will import in order to stop the dumping of food from other countries.

Agroecology is a concept associated with Food Sovereignty, defined as the doctrine of interaction between plants, animals, humans and the environment for food production that is adapted to different ecosystems.

Set against the backdrop of the international challenges, the world has to produce enough healthy food in a sustainable way and to allocate the resources fairly. A Nordic climate project for agriculture cannot therefore unilaterally propose technical measures to camouflage and limit emissions due to agriculture, or accept production methods in Scandinavia without taking into account the greatest challenges facing the Earth and humanity.

\subsubsection{Conclusions}

All the countries have detailed national or regional regulations in force concerning manure storage and the use and spreading of solid dung and slurry. Denmark and Finland have the most stringent and detailed regulations, whereas the regulations in Sweden and Norway are more flexible, taking into account regional differences and factors that may render certain areas more "sensitive" (also from a biodiversity perspective) than others.

The present support systems for agriculture have mainly favoured more intensive and large-scale farming. This is partly due to the fact that large-scale and intensive farmers often have been better represented by the sector's interest organisations. Another fact of significance is that increased production has historically been central to agricultural policy, while other interests have been subordinated. This said, without the 
support systems present today and in a free market there would probably not be much agricultural activity at all in the Nordic countries outside some of the most intensive farming areas on the plains.

It is also clear that agriculture today does not pay for the external environmental and health costs that the emissions from agriculture cause. This can be seen as an indirect subsidy to agriculture with high emissions. One reason for the absence of environmental taxes in agriculture is that emissions are often diffuse and difficult to measure. Competition in a global market (and especially in the EU) is another reason why few countries dare to go further in terms of environmental taxes and regulation.

We postulate that in a transparent and working democracy, increased public awareness would lead to the internalisation of the environmental costs associated with intensive farming (domestically and abroad), a revision of the subsidies system promoting low agricultural product prices, and a re-evaluation of consumer choices regarding the consumption of crop and animal products.

This chapter also considered more global concerns arising from today's agricultural systems and food policies, such as poverty and starvation. Taking into account the international challenges, the world has to produce enough healthy food in a sustainable way, and allocate the resources fairly. A Nordic climate project for agriculture cannot therefore unilaterally propose technical measures and accept production methods in Scandinavia without taking into account the greatest challenges facing Earth and humanity. 



\section{System analysis}

\subsection{Introduction}

This chapter aims to present a bigger picture of many of the issues covered in the report. The various emissions from the agricultural sector, their interrelation and their impact are immensely complex. A system analysis helps us to understand the various relationships, cycles and impacts. It also contributes to identifying possible ways to address problems and shortcomings in agricultural production, their associated costs and their environmental impact.

Two group-modelling workshops were organised during this project, with the aim of getting an overview of the physical and socio-economic systems that affect emissions of greenhouse gases and air pollution (mainly ammonia) from agriculture. About 15 people took part in the two workshops on both occasions, some of whom were present at both.

The work resulted in the Causal Loop Diagrams below and the knowledge-sharing is reflected in the text. The following can be considered as our collective learning from the workshops (when reading the loop diagrams note the plus and minus symbols indicating the interrelations).

\subsection{System boundaries}

The purpose of agricultural activity is obviously the production of crops and animal produce.

Within the above-mentioned workshops, we soon identified excess animal production - and the industrial agriculture behind it - as the main causes for the huge emissions related to our food production systems. Following on from this, we started focusing on the physical boundaries and the degree of exploitation within these boundaries:

- Industrial agricultural crop production (highly mechanised; monocultures).

- Industrial animal production (depending on large-scale land use for feed and feed imports).

- Land use and agricultural production. 
This list is in no way an exhaustive outline of the food production system in the Nordic countries, but keeps the focus on a practical sector focusing on land-based agricultural food production.

\subsubsection{Industrial agricultural crop production}

Crop production depends on the availability of soil nutrients, water and soil tillage.

Industrial agricultural crop production is promoted by the availability of fertilisers, irrigation, drainage and intense use of machinery. Industrial agriculture promotes monocultures, diminishes biodiversity and undermines soil resilience.

Crop production is hampered by pests and adverse soil conditions. In the industrial agricultural system the cure is pesticides, which may be harmful to soil biodiversity and soil resilience.

Machinery used to facilitate large-scale crop production can lead to soil compaction and cause anaerobic conditions in soil and a loss of soil biodiversity. Drainage can alleviate the anaerobic conditions in the soil.

Large-scale crop production gives rise to eutrophication and emissions of $\mathrm{NH}_{3}$, the greenhouse gas $\mathrm{N}_{2} \mathrm{O}$ as well as emissions of $\mathrm{CO}_{2}$ (from land use and from the use of machinery).

Other ways - with less environmental impact (e.g. organic/biodynamic agriculture or permaculture) - to produce crops exist and are developed in parallel with industrial agriculture. The necessary plant nutrients can be delivered via recycling, composting, introducing legumes in crop rotation and as companion cultures. The negative effect of pests on crop production can be controlled through the use of crop rotation and companion cultures, both of which also contribute to higher soil nutrient availability and reduced soil compaction. These systems all work with smaller animal density than is acceptable in conventional agriculture. However, these systems can also have high emissions per kilo of product.

Highly mechanised large-scale crop production is a precondition for industrial animal production. 


\subsubsection{Industrial animal production}

There is an ongoing competition between the quality of animal produce and the quantity produced.

Figure 9: The trade-off between quality and quantity of animal produce

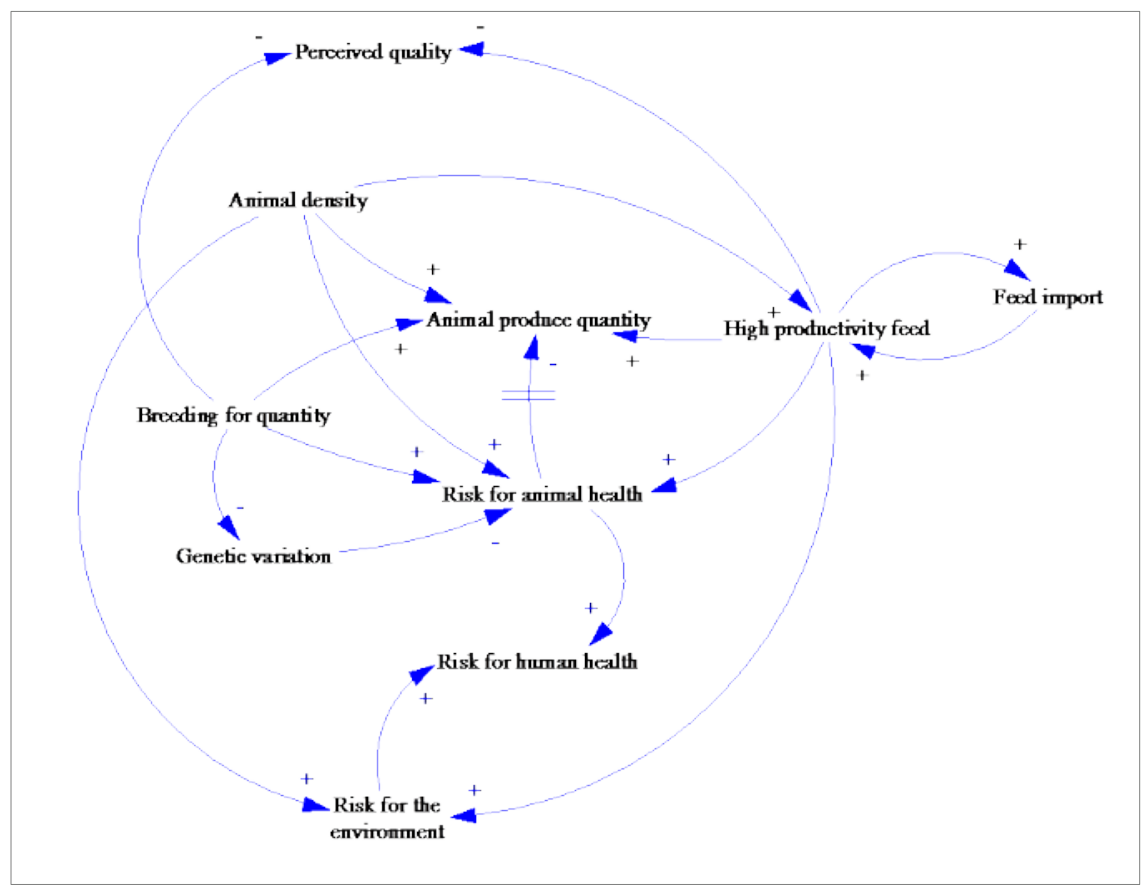

Breeding for quantity reflects the selection of special genetic traits in animals to promote fast growth and high production of milk, eggs, meat, etc.

This has proven to be a successful measure in Europe. However, this breeding strategy is showing strong undesired side effects including the deterioration of animal health in general, the loss of genetic variation in the animal stock, and an increasing sensitivity to infectious diseases.

Added to this are the implications of fast growth and productivity on animal welfare in the form of e.g. lack of access to a free-range area and sunlight or the ability to walk. Further, deterioration in animal health increases the risks to human health, as was the case in the recent outbreaks of foot and mouth disease (2001), swine flu (2009) and avian flu or "bird flu" $(2003,2012)$, MRSA (in Denmark 2014) among others.

To sustain intensive animal production, high levels of animal density are required. Locally produced animal feed (in Europe) is insufficient to sustain the current high numbers of animals, and instead large amounts of high productivity feed, currently dominated by protein-rich soya, need to be imported. The high animal densities and the high in- 
flux of nutrient-rich feed increase the pressure on the environment in the form of gaseous emissions, nutrient leaching and the leaching of hormones and antibiotics. Increasing pressure on the ability of surrounding ecosystems to absorb and dilute the pollutants also increases the risks to human health.

Beyond the physical effects of intensive animal husbandry, there is also an impact on the perception of animal produce quality among consumers. For some consumers (concerned about the environment, health, animal welfare and/or "eating quality"/taste), the perceived quality of the animal produce is reduced by the use of high productivity feed and by selective breeding for large-scale production/fast growth.

Less intensive animal production - less dependent on imported feed - exists in parallel with industrial animal production. The geography of the Nordic countries in many cases determines the method of production. In mountainous areas, grazing animals are the only possible way to produce food. Similarly, lowlands and marshes in Denmark, Sweden and Finland are well suited for grazing animals, as are some other nature areas. Organic agricultural methods for animal rearing are developing and increasing in all the Nordic countries. These forms of animal rearing are all less intensive, and experience (from Denmark) has shown that "organic consumers" eat less meat.

Greenhouse gas emissions related to animal production are huge and arise from ruminants $\left(\mathrm{CH}_{4}\right)$ and manure $\left(\mathrm{CH}_{4}\right.$ and $\left.\mathrm{N}_{2} \mathrm{O}\right)$. It is debatable whether meat and milk from grass-fed ruminants emit less or more greenhouse gases than grain-fed animals that are fed on a large proportion of maize for instance. When seen from a holistic perspective, where soil carbon is also accounted for, there are some benefits associated with grassland, in relation to climate, biodiversity and animal welfare, which are not present in fields that have annual crops. However, we have not been able to find clear evidence in favour of one system over the other regarding the climate effects.

\subsubsection{Land use and agricultural production}

We distinguished four types of land use relevant to the question at hand. Of these, three contribute to agricultural food production directly, namely the traditional semi-natural areas (used for grazing and food collection), polyculture areas (with a diversity of crops and animals) and monoculture areas (industrial methods of producing feed and food). The contributions of these three land use forms to agricultural production vary in intensity. 
The different land use types have different effects on biodiversity, and only monocultures are thought to have a severe negative effect. Biodiversity is itself important for food production, for example by assuring the presence of pollinators necessary for crop production and a diversity of insects including beneficial organisms/predators that combat harmful insects.

Figure 10: Different forms of land use contribute differently to food production

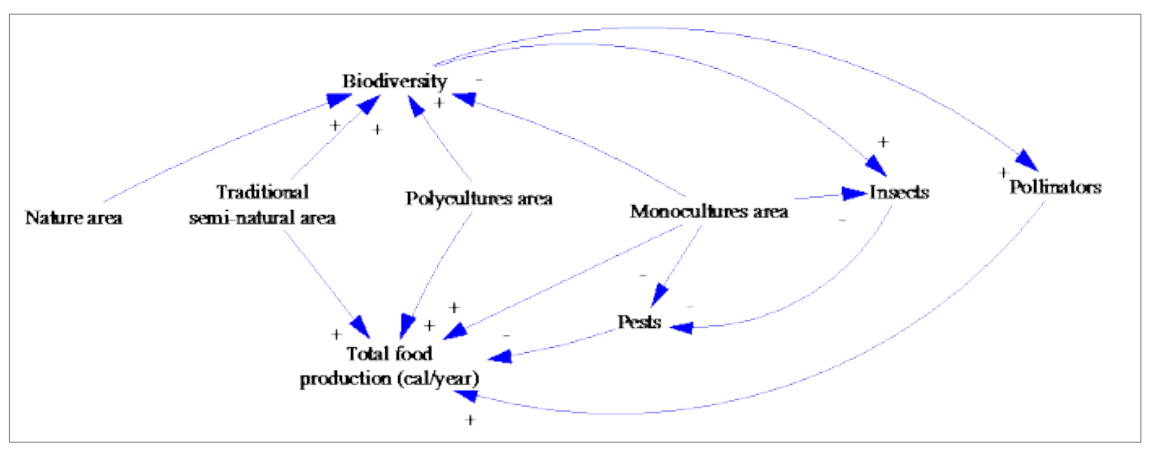

It is argued that industrial agriculture produces efficiently and with a low carbon footprint. Efficiency is associated here with a high yield per unit of land obtained through the use of pesticides and fertilisers. In livestock production this so-called efficiency is achieved, for example, by squeezing more milk out of dairy cows, or piglets out of sows, or by breeding chickens to grow faster. However, livestock production is itself an inefficient way to ensure healthy and sufficient food for the world's population, because so much of the crop is channelled through the livestock and therefore so much land is necessary. In Denmark, for instance, more than $80 \%$ of agricultural land is used for the production of livestock feed. In addition, Danish agricultural production requires an area at least the size of Zealand, primarily in Argentina and Brazil, for the production of soy protein feed. A food production system that contributes to excess animal product consumption amongst the more prosperous people on the planet is therefore a socially, climatically and environmentally destructive system.

Another way of looking at efficiency would be to look at the capacity to feed the world with the least possible damage to the climate and environment by limiting livestock production and animal consumption. 


\subsection{Socio-economic systems}

While the physical systems described above are related to different degrees of exploitation of the natural limitations constraining agriculture, they are steered by decisions made in the socio-economic sphere. In this section we explore the socio-economic drivers behind the decisions made by agricultural producers regarding production methods and quantities, as well as consumer choices.

- Profitability to farmers of two different agricultural animal-rearing methods.

- Drivers behind the farmer's decision to rear animals.

- Drivers behind consumer decisions on animal product consumption.

- Political decision-making.

- The ethical grounds affecting decision-making related to agricultural food production and consumption.

\subsubsection{Profitability to farmers of two different agricultural animal-rearing methods}

Profitability may be one of the most important parameters that influence the choice of farming methods by agricultural producers. Agricultural producers have to conform to traditional business ideology, implying that their investments in time and capital must generate enough revenue from agricultural production to cover costs and a marginal profit.

For sustainable farming, the costs are often direct and largely defined by labour costs (see figure 3, right) although there is also a need for investment in stables, land etc. These costs lower profitability, unless it is supported by higher revenues stemming from higher yields, access to markets, and the ability and willingness of customers to buy these products. There is also the possibility of alleviating these extra costs through extra subsidies.

Similarly, conventional farming is profitable when its associated costs are lower than its revenues (see figure 3, left). With the current direct subsidies system and a production system based on high quantities and minimal labour, the costs are kept low, except for investments in stables and machinery.

What is not usually explicitly stated is that conventional agriculture, considerably more so than sustainable farming, gives rise to a significant amount of pollution, the costs of which it does not currently cover. This 
is an indirect form of subsidy, considering that society incurs the cost of pollution from conventional agriculture. Sustainable agriculture, which is believed to produce much smaller amounts of pollutants, does not pass on such costs to society.

Figure 11: Mechanisms of financial profitability of two agricultural systems left: conventional agriculture, and right: sustainable agriculture

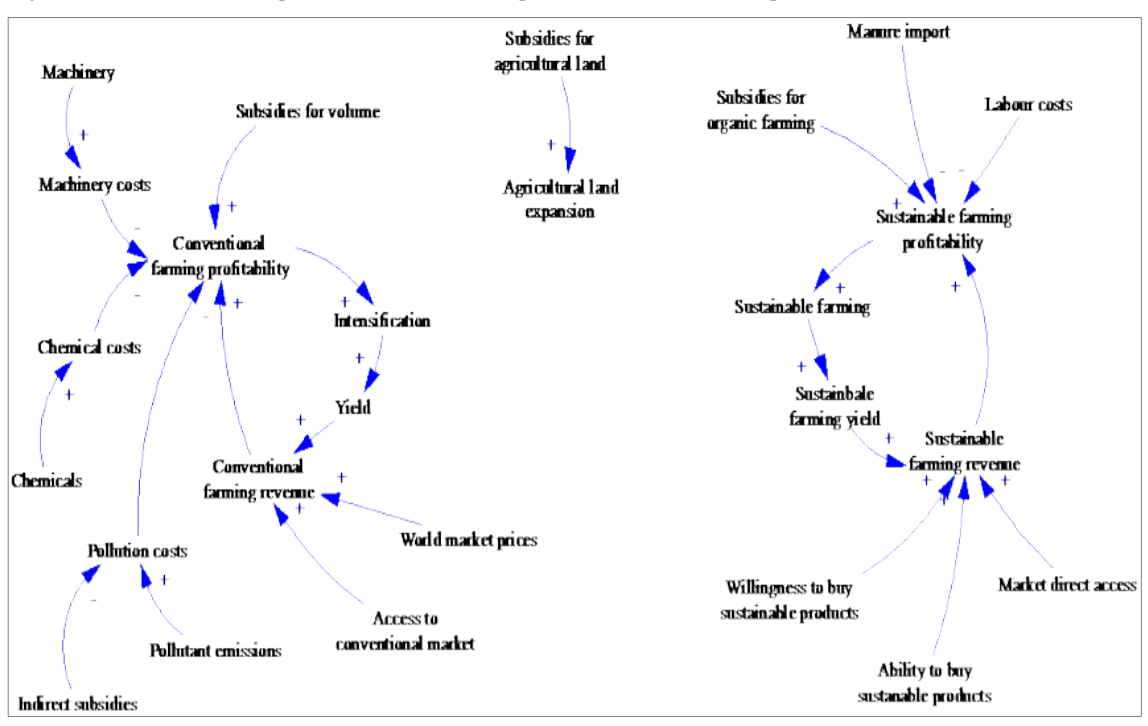

\subsubsection{Drivers behind the farmer's decision to rear animals}

The decision to shift agricultural production increasingly towards animal produce is primarily driven by the continuous increase in revenue from animal production. The latter is in turn driven by an increase in the demand for animal products, resulting from wider market access (global market), higher ability to pay (globally) for animal products but also a strong willingness to buy animal products. Should one of these three variables be limiting (as historically the ability to pay has been low), the demand for animal products would decrease.

The reinforcing loop is made even stronger by social influence among farmers, by which we postulate that a farmer's decision is influenced by other farmers' successes.

On the other hand the farmer has to consider the costs of both investment (stables and machinery) and imports (feed, fertilisers, pesticides) - and compare with the direct revenue from crops. The costs associated with the establishment of animal production units compel 
farmers to take out loans, which then require continuous revenue generation to cover the associated mortgages.

Currently, however, the various pros and cons are disturbed by external influences such as the lowering of production costs (cheaper imports, subsidies), and the artificial distortion of crop revenues (the prices of which are kept low in the global market through production subsidies). This leads to artificially strong feedback loops between the decision to rear more animals, the volume of animal husbandry, and the revenues associated with animal rearing.

Active lobbying also contributes to the distortion of the balancing system that governs the scale of animal husbandry. Lobbying can target decision-makers, farmers and public opinion. Lobbying in different forms can influence regulation and subsidies to promote animal farming on a large scale and with high intensity, the perception among farmers of the prospects of high revenue from animal husbandry, and contribute to wider market access and higher consumer sympathy towards animal products regardless of production methods.

Figure 12: Intensive animal production is partly driven by increasing demand for animal products on a global market

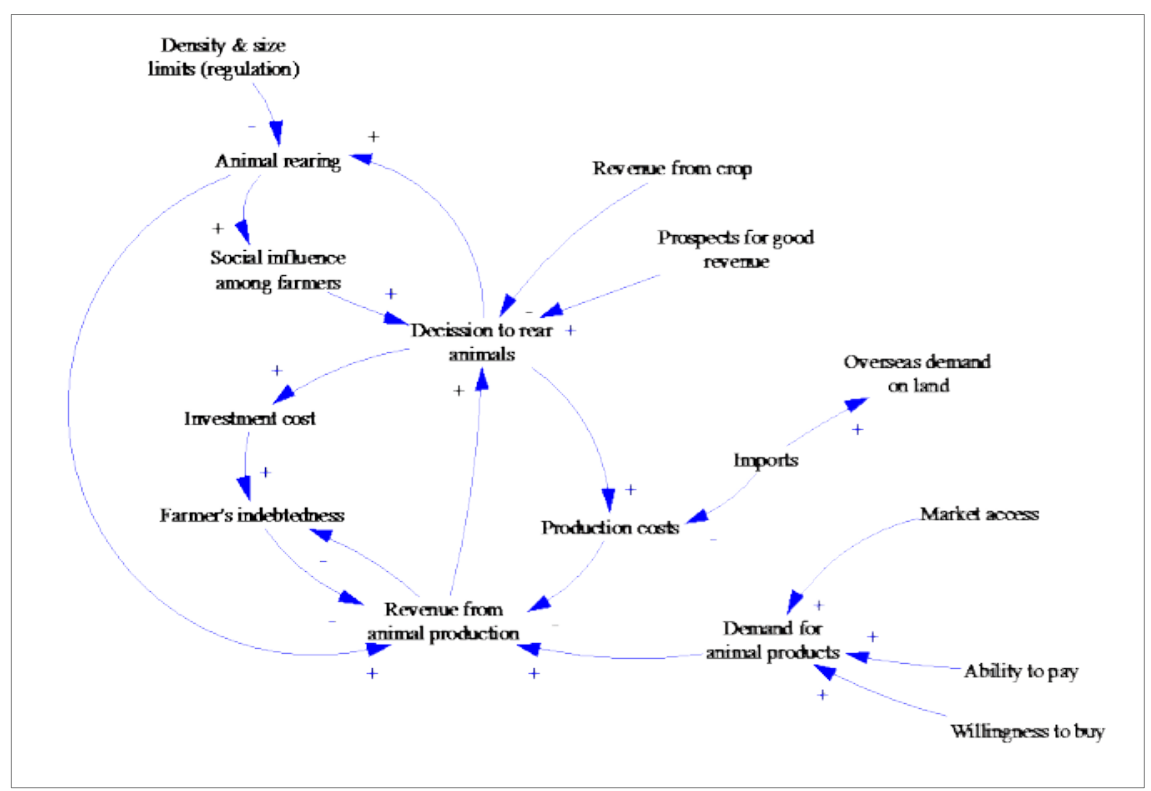




\subsubsection{Drivers behind consumer decisions on animal product consumption}

We postulate that the demand for animal products stems from three variables: 1) the willingness to consume animal products, 2) the ability to buy animal products, and 3) the lack of availability of alternative products (Figure 5). The willingness to consume animal products is part of social traditions and culture, originating from the fact that meat and other animal products, besides their high nutritious content, have historically been scarce and therefore associated with higher social status.

Increasing awareness about the negative impacts of intensive animal husbandry, as well as alternatives to animal products, has the potential to erode people's willingness to consume the latter. Awareness stems primarily from education and better access to information about agricultural production systems and their implications (for the environment, animals and human health).

The ability to buy animal products remains a strong driver for the high demand for these products. This is the combined result of low animal product prices on one hand, and greater ability to pay (due to higher affluence) on the other.

In many cultures, meat and dairy products are considered to be the most natural, healthiest and most environmentally friendly foods, based on climatic conditions and renewable resources found locally. However, it seems that there is a globalisation of food traditions through which cultures that have traditionally had a higher intake of vegetables, are increasing their consumption of meat, probably driven by higher incomes and thus greater opportunity to buy foods. One can discuss whether western patterns of meat consumption are also the driving force behind such changes in consumption, as traditionally poor countries copy western patterns when their economy allows it.

It is also important to note the strong and persistent impact of lobbying/manipulating. This takes different forms, from advertising to the design of school meals and general dietary guidelines. 
Figure 13: Drivers of the demand for animal products

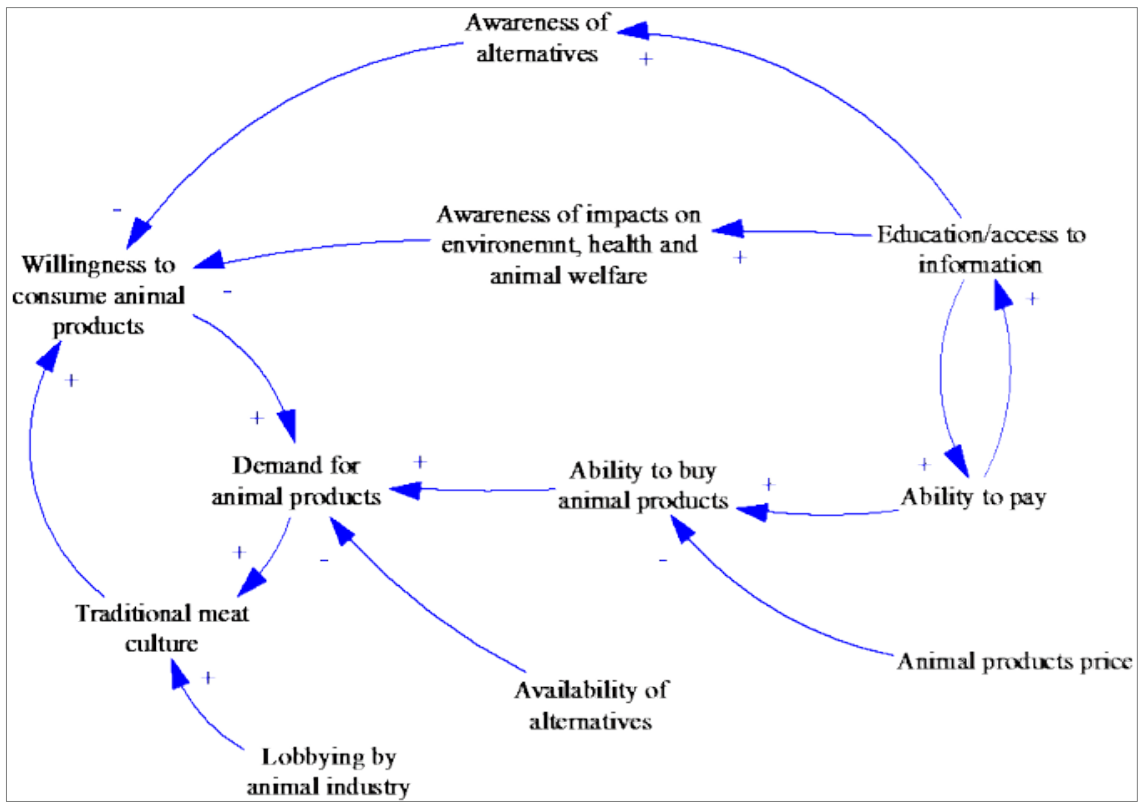

\subsubsection{Political decision-making}

Subsidies, access to markets and price regulations are some of the more detrimental factors affecting the socio-economic system of decisionmaking that steers the choice of agricultural production types. Behind these factors lie a political system and an ethical framework that we attempt to describe in the diagram below.

Figure 14: The mechanism affecting agricultural policy

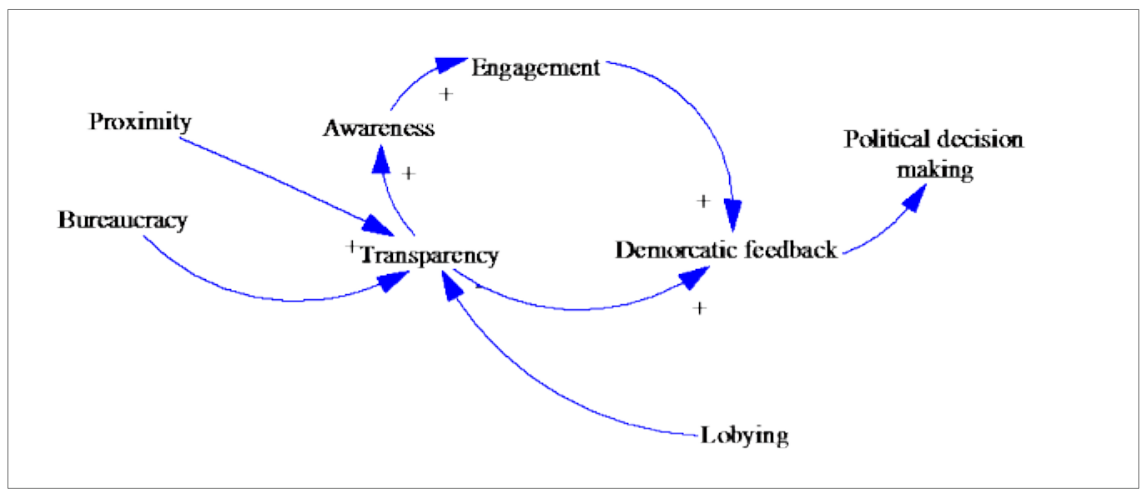

As long as awareness, engagement, transparency, democratic feedback and proximity are weaker than lobbying by the big farmers' organisations, we will still be facing the status quo. 


\subsection{Synthesis: Towards an integrated system model}

The partial Causal Loop Diagrams presented above describe components of the current agricultural system and the associated emissions. It is the interactions between these components that explain the behaviour of the entire system, summarised in Figure 15 below.

Crop production and animal production both have environmental impacts, including ecosystem resilience (e.g. soil resilience and biodiversity sensitivity), eutrophication and greenhouse gas emissions. Traditionally, crop production and animal production were linked in a mutually reinforcing feedback loop, whereby crops were used to feed animals and animal manure was used to fertilise crop production. At low intensities of agricultural activity, the environmental impacts remained local in scale and small in magnitude.

As Nordic societies became more affluent, the ability to buy food products (crops and animal products) grew stronger. This, together with increasing demand for food (partly due to growing populations) and low agricultural product prices, led to higher demand for both crop and animal products. This has a cascade effect, increasing farmers' revenues and encouraging intensive farming to meet the growing demand (further encouraged by access to foreign markets and access to fertilisers, pesticides and specialised machinery).

The direct costs of intensive farming are kept artificially low by the current agricultural policy, which advocates the subsidising of farming in the Nordic countries (both within and outside EU). Beyond the direct subsidies, intensive farming does not currently account for its related environmental costs, making the prices of its products artificially low.

Our analysis points to the central importance of what we refer to as the "environmental and social awareness" of the public. We postulate that in a transparent and working democracy, increased public awareness would lead to the internalisation of the environmental costs associated with intensive farming (domestically and abroad), a revision of the subsidies system that promotes low agricultural product prices, and a re-evaluation of consumer choices regarding the consumption of crop and animal products. 
Figure 15: A holistic picture of the drivers behind emissions from agriculture

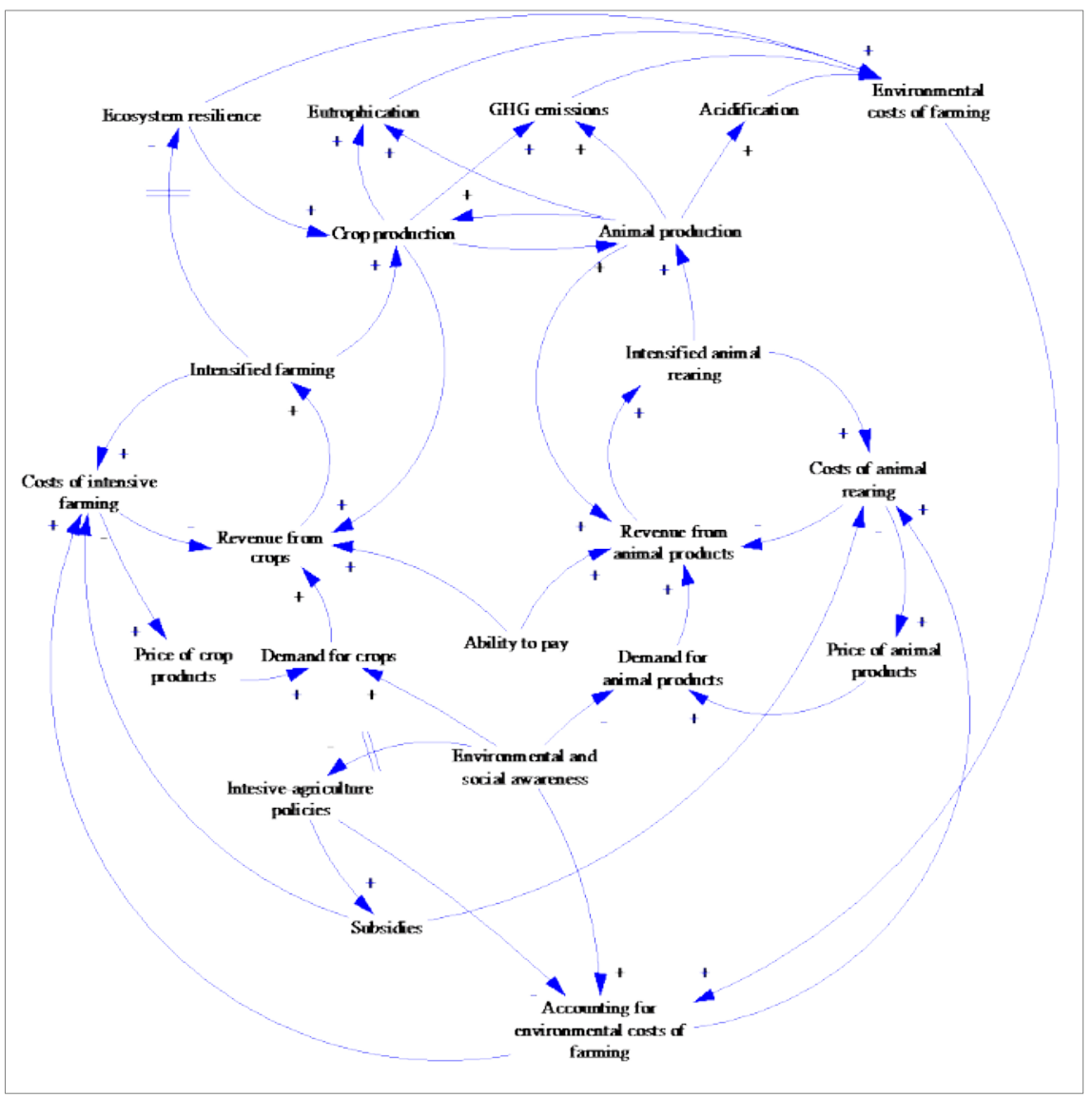

The physical emissions are affected by the type of production system. It is possible to reduce emissions to a certain extent through various types of technical efficiency measures, but it is impossible to achieve farming with zero emissions of greenhouse gases and nitrogen. The volume produced is therefore closely related to the amount of emissions. Livestock production usually results in higher emissions per calorie produced compared to the production of crops.

Intensive and specialised farming may give rise to relatively low emissions per produced unit of product. For instance, area-dependent emissions will be lower per kilogram of grain when yields are high, and methane emissions may be lower for livestock with fast growth and short lives. In this type of agriculture it is also possible to use e.g. precision-farming technologies that also lead to emission reductions. On the other hand, this type of agriculture is dependent on external inputs in the form of feed and fertiliser. Furthermore, the concentrated production also leads to higher environmental impact locally. 
Less intensive farming may have higher emissions per unit produced. But it is also possible that a reduced dependency on external inputs and the ability to use local resource flows will lead to lower emissions. Furthermore, less intensive farming systems have smaller animal densities and are often serve local consumers who consume smaller proportions of animal products. The cost of labour is relatively high in this type of farming.

Profitability is a crucial factor in the choice of production systems. This in turn depends on costs for inputs, access to market and imports, free trade and competition, consumer demand for products, agricultural policy and the design of support systems for agriculture.

What individual consumers demand depends partly on their ability and willingness to pay. That ability to pay depends on a combination of consumer income, food prices and preferences. In most countries where consumers' ability to pay increases there is also an increase in the consumption of relatively more expensive but also more emissionsintensive products such as meat and cheese. If this still applies to the level of prosperity that the Nordic countries have achieved is unclear.

The choice of food is also influenced by values (such as environmental and social awareness). Consumer choices are also limited by what is available in the market and the availability of information about the products and how they were produced, as well as knowledge and information on how to compose and prepare a healthy diet.

The present support systems for agriculture have mainly favoured more intensive and large-scale farming. This is partly due to the fact that large-scale and intensive farmers have often been better represented by the sector's own interest organisations. Another fact of significance is that growth in production has historically been central to agricultural policy, while other interests were subordinated. On the other hand, without the support system present today and in a free market there might not be much agricultural activity at all in the Nordic countries outside some of the most intensive farming areas. Nevertheless there is a need to revise the support system in order to promote more environmentally and climate-friendly agriculture.

It is also clear that agriculture today does not pay for the external environmental and health costs that the emissions from agriculture cause. This can be seen as an indirect subsidy to agriculture with high emissions.

One reason for the absence of environmental taxes in agriculture is that emissions are often diffuse and difficult to measure. Competition in a global market (and especially in the EU) is another reason that few countries dare to go further in terms of environmental taxes and regulation. 
Our analysis points to the central importance of what we refer to as the "environmental and social awareness" of the public. Theoretically, in a transparent and working democracy, increased public awareness would lead to the internalisation of the environmental costs associated with intensive farming, a revision of the subsidies system that promotes low agricultural product prices, and a re-evaluation of consumer choices regarding the consumption of crop and animal products. However, in practice more measures and awareness-raising are necessary to achieve this internalisation of environmental costs and achieve a paradigm shift in agricultural production and consumption of agricultural products. 


\section{Measures to reduce emissions}

\subsection{Introduction}

Chapter 6 gives an overview of the type of technical, organisational and policy measures that could be used to reduce greenhouse gas and other air pollutants from the agricultural sector, together with three case studies. The application of these measures in the Nordic countries vary in application and scope, largely depending on the overall policy climate, the landscape structure, the proportion of larger-scale and smallholder farmers, the cultural setting, the existence of incentive systems, and the perceived scope of the environmental and climate issues linked to farming.

The first part of this chapter features an inventory of measures, divided into various categories, i.e. manure and fertiliser management, energy efficiency, feeding, land use, production of energy from the agricultural sector, and other measures. This inventory briefly describes the various measures, their area of application, the processes involved and the potential impact on the environment and on animal husbandry. This inventory is not exhaustive by any means. It mainly provides examples that are being used in one way or another.

In this chapter we have also selected a few case studies, which are presented to have great potentials for further exploration, use and promotion at national, Nordic and European level. Our aim was to look at these technologies in a more neutral manner, and therefore to enlighten also the critical aspects of the technologies when considered from a holistic perspective. Two of them, biogas and green biomass practices, have been the subject of great deal of discussions at EU level and in some countries huge investments are on-going in exploring the biomass sector especially regarding biogas. The third one, acidification of slurry, is a relatively well-established technology, which is widely used in some countries (e.g. Denmark).

The objective of this chapter is to present the practices, explore to what extent they are being used in the Nordic countries, what are the bottlenecks and enabling factors that policy makers need to address to spread their usage, as well as to present some of the "pros and cons" 
related to the different technologies and practises. Bottlenecks may be legal obstacles, reluctance from the farmers that may apply the practices or conflicts of interests. One such conflict of interest is the possible preference of using land for producing food for human or animal consumption rather than biomass for producing fuels for transportation vehicles or additional biomass for the biogas production. In our next project period, we will include a further evaluation of the measures in order to see what role each of them can play in a scenario for "A new Nordic food system's contribution to global sustainable food systems and climate mitigation".

\subsection{Inventory of measures}

The presence in each country is marked either as commonplace (C), on trial basis (T), non-existent $(\mathrm{N})$ or uncertain (U). Where we have not found concrete information about a measures application we indicate it with These are quite rough indicators; several measures are often grouped together and one of them might be commonplace while the others are still on trial or non-existent.

\subsubsection{Measures to reduce emissions from manure and fertilisers}

\section{Decreasing the time that emissions can take place, i.e. through} frequent removal of the slurry/manure in stables

- Effect on: $\mathrm{NH}_{3}$.

- Presence: Denmark (T), Finland (C), Norway (C), Sweden (C).

- Concerns for animal welfare: U.

If excreta are removed from the livestock building as soon as possible, ammonia emissions will reduce. Rapid separation of manure and urine in the barn and storing them separately will also reduce the conversion of urea to ammonium, thereby limiting emissions.

For cattle it is possible to use grooved floors, with scrapers that move over the floor frequently. Urine is drained through perforations in the floor. Ammonia reductions of $25-40 \%$ can be achieved compared to a conventional system. 
For pigs it is common to use slatted floors, however these can cause injuries. In systems where pigs move freely usually only parts of the floors are slatted.

\section{Acidification of slurry}

- Effect on: $\mathrm{NH}_{3}, \mathrm{~N}_{2} \mathrm{O}, \mathrm{CH}_{4}$.

- Presence: Denmark (C), Finland (T), Norway (N), Sweden (T).

- Concerns for animal welfare: no.

Lowering the $\mathrm{pH}$ of slurry is a way to reduce ammonia and methane emissions. This is commonly done by adding sulphuric acid and can be done at several stages of manure handling. Acidification is at present not an accepted method in organic agriculture. It is not possible to use acidified slurry in biogas systems.

See also case study on acidification of slurry.

\section{Other additives i.e. urease inhibitors, nitrification inhibitors and lowering ammonia concentration through dilution}

- Effect on: $\mathrm{NH}_{3}\left(\mathrm{~N}_{2} \mathrm{O}\right)$.

- Presence: Denmark (C), Finland (N), Norway (C), Sweden (N/C).

- Concerns for animal welfare: no.

Urease inhibitors are used to decrease ammonia from urea, a mineral fertiliser that is hardly used in the Nordic countries.

Nitrification inhibitors are compounds that prevent the conversion of ammonia into nitrate. They can be applied in animal manure and fertiliser, and can lead to a decrease in fertiliser use or a higher nitrogen uptake in arable crops and grassland.

Ammonia emissions from diluted slurry are generally less than for undiluted slurry because of faster infiltration into the soil. This is sometimes done if slurry can be added through a lower-pressure irrigation system or for viscous slurries before application. This is more commonly used than adding inhibitors. 


\section{Covering of slurry tanks}

- Effect on: $\mathrm{NH}_{3}, \mathrm{~N}_{2} \mathrm{O}, \mathrm{CH}_{4}$.

- Presence: Denmark (C), Finland (C), Norway (C), Sweden (C).

- Concerns for animal welfare: no.

By reducing contact between the air and the stored the manure it is possible to reduce emissions of both ammonia and methane.

In the design of new storage systems one simple measure to reduce emissions is to reduce the surface area per unit volume, this means that silos are preferable to lagoons.

Another possibility for reducing emissions from manure storage is different types of coverage.

The simplest one for slurry is a floating crust, which is estimated to reduce ammonia emissions by $40-65 \%$. When a crust does not form naturally, straw or LECA balls can be added to help the formation of a crust.

Floating covers are the next step up. They are usually made of plastic sheets. Some designs exclude rainfall from mixing with the slurry, which increases the storage volume. This measure is estimated to reduce ammonia emissions by $60-90 \%$.

Solid covers like a lid or roof are the most effective and can reduce emissions by $80-95 \%$.

The only drawback is that the more advanced and effective models require significant investment.

\section{Cover and/or turn over solid manure heaps}

- Effect on: $\mathrm{NH}_{3}, \mathrm{~N}_{2} \mathrm{O}, \mathrm{CH}_{4}$.

- Presence: Denmark (C), Finland (C), Norway (C), Sweden (U).

- Concerns for animal welfare: no.

For solid manure, options are fewer, but coverage with plastic sheets has proven to be an effective way to reduce ammonia, nitrous oxide and methane emissions.

By continuous turning over of manure heaps it is possible to avoid hypoxia. This reduces methane emissions, but unfortunately increases ammonia emissions instead. 


\section{Optimise fertilisation}

- Effect on: $\mathrm{NH}_{3}, \mathrm{~N}_{2} \mathrm{O}, \mathrm{CH}_{4}$.

- Presence: Denmark (C), Finland (C), Norway (C), Sweden (C).

- Concerns for animal welfare: no.

Nitrous oxide and ammonia emissions can be reduced if the supply of nitrogen to the fields is reduced. This can be done through more accurate analyses of crop nitrogen requirements and nitrogen content in manure. Furthermore, the time for application of manure should take into account the weather and growing season so that the risk of leakage is reduced, which also reduces the risk of nitrous oxide and ammonia emissions from soil.

Demands to optimise the use of the Nitrogen in the manure and thereby reduce the use of fertiliser have been the main reason for reduced $\mathrm{NH}_{3}$ and $\mathrm{N}_{2} \mathrm{O}$ emissions in Denmark in the last 30 years. It is connected (in Denmark) to the notion of a "nitrogen norm".

In Finland, the use of mineral fertilisers decreased significantly from 1990 to 2011. Nitrate regulation (which enforces the Nitrates Directive) sets limits for how much nitrogen fertiliser may be applied. In Finland so far almost all farms have participated in an agri-environmental measure under the Rural Development Programme that requires stricter rules for fertiliser (both manure and mineral). It is estimated that nitrous oxide emissions have been reduced as a result.

In Sweden, Norway and Finland, nitrogen optimisation is farmers' own responsibility. They do however receive support in the form of advice.

\section{Reduce fertiliser dose to below today's recommended level}

- Effect on: $\mathrm{NH}_{3}, \mathrm{~N}_{2} \mathrm{O}, \mathrm{CH}_{4},\left(\mathrm{CO}_{2}\right)$.

- Presence: Denmark (T), Finland (N), Norway (N), Sweden (T).

- Concerns for animal welfare: no.

This measure is similar to "optimise fertilisation" above, but aims instead to reduce fertiliser use to below the present economical optimum. Lower nitrogen application will decrease nitrogen losses (a higher percentage of the applied nitrogen will actually be used by the crop), but also reduce yields. However, it is important to note that the relationship is not linear. If the nitrogen input is reduced by $50 \%$ compared with the optimum level it would lead to a $15 \%$ decrease in grain harvest in the first year and if the nitrogen supply continues to be held at half the optimal application rate the yield would decrease by $25 \%$. However there 
is a risk that harvest reductions could lead to forest clearing for more agricultural land, which would lead to higher carbon emissions.

In Denmark, the nitrogen norm (meaning the amount of nitrogen that is allowed to be applied to crops over a season) is defined for all crops and includes both manure and fertiliser. The norm was originally based on the optimum amount of nitrogen that was needed to sustain the agricultural economy, but in recent years the norm has been set below this figure for environmental reasons. Conventional farmers argue for regulation that allows more nitrogen to be applied to so-called robust soils/systems and less to vulnerable systems, arguing that this will increase self-sufficiency in fodder and (indirectly) reduce land use. However, emissions and nitrogen leaching will increase.

\section{Decreasing the surface area where emissions can take place, i.e. through band application, trailing shoe or injection}

- Effect on: $\mathrm{NH}_{3}$.

- Presence: Denmark (C), Finland (C), Norway (C), Sweden (C).

- Concerns for animal welfare: no.

Various techniques can be used to reduce contact with air while applying manure to the soil, and thus reduce emissions. Currently there are only established techniques for slurry and not for solid manures.

The original technique for spreading slurry is by the splash plate method. This method of application can result in up to $80 \%$ of the available nitrogen applied in the slurry being lost to the atmosphere in the form of ammonia. The result is loss of this valuable nutrient, as well as atmospheric pollution. One simple way to minimise such losses is to reduce the surface area of the spread slurry that is exposed to the air.

Systems of slurry spreading that minimise the surface area of the spread slurry exposed to air and lower ammonia loss are widely used across Europe. These alternatives include:

- Band spreading.

- Trailing-shoe application.

- Injection (shallow and deep).

The suitability of each of these methods varies depending on the type of soil and whether manure is spread on bare soil or in growing crops. 
Decreasing the time that emissions can take place, i.e. through rapid incorporation of manure into the soil or immediate irrigation

- Effect on: $\mathrm{NH}_{3}$.

- Presence: Denmark (C), Finland (C), Norway (C), Sweden (C).

- Concerns for animal welfare: no.

Rapid incorporation into the soil immediately or within a few hours after application is a method that be used for both slurry and solid manures. If done within four hours it is possible to achieve $60-90 \%$ reductions for solid manure, compared to only $30 \%$ reductions if done within 24 hours.

Increase the use of green manure (legumes) in pastures and fields

- Effect on: $\left(\mathrm{NH}_{3}\right), \mathrm{N}_{2} \mathrm{O}, \mathrm{CO}_{2}$.

- Presence: Denmark (C), Finland (C), Norway (C), Sweden (N).

- Concerns for animal welfare: no.

Reduces the need to produce synthetic fertilisers and hence the use of energy to produce them. This is a common practice on organic farms, but less common on conventional farms.

\section{Use waste water treatment sludge as fertiliser (N)}

- Effect on: $\mathrm{N}_{2} \mathrm{O}, \mathrm{CO}_{2}$.

- Presence: Denmark (C), Finland (T), Norway (T), Sweden (C).

- Concerns for animal welfare: no.

Reduces the need to produce synthetic fertilisers and hence the use of energy to produce them. One serious problem is that the concentrations of hazardous substances (heavy metals, hormones, antibiotics) can be high.

Increase utilisation of digested manure and/or forage from biogas production as substitute for other fertilisers

- Effect on: $\mathrm{N}_{2} \mathrm{O}, \mathrm{CO}_{2}$.

- Presence: Denmark (T/C), Finland (T), Norway (C), Sweden (C).

- Concerns for animal welfare: no.

Nitrogen in digested manure and/or forage is more directly available for plants than in unprocessed manure. This increases the risk of immediate 
losses and it is therefore even more important to use application techniques that minimise air contact and that application takes place during the growing season. The digest is easier to handle compared to untreated manure and is therefore easier to dose more accurately.

See also case study on biogas.

\section{Use fertilisers manufactured with BAT}

- Effect on: $\mathrm{N}_{2} \mathrm{O}, \mathrm{CO}_{2}$.

- Presence: Denmark (C), Finland (C), Norway (C), Sweden (C).

- Concerns for animal welfare: no.

The process of making nitrogen fertilisers requires a lot of energy and contributes to nitrous oxide emissions. Over the last decade there have been huge improvements in the technology and emissions have decreased. However, fertiliser is still imported from Russia, where the old technology is used.

Concerns for animal welfare: no.

\subsubsection{Feeding measures}

\section{Low-protein feed, with or without supplementation of specific} synthetic amino acids

- Effect on: $\mathrm{NH}_{3}, \mathrm{~N}_{2} \mathrm{O}$.

- Presence: Denmark (C (only for young piglets)), Finland (T), Norway (T), Sweden (C).

- Concerns for animal welfare: U.

Low-protein animal feed is one of the most cost-effective and strategic ways of reducing ammonia emissions. For each per cent (absolute value) decrease in protein content of the animal feed, ammonia emissions from animal housing, manure storage and the application of animal manure to land are decreased by $5-15 \%$.

Low-protein animal feed is less applicable to grassland-based systems with grazing animals, because grass and legumes in an early physiological growth stage have a relatively high protein content. However, there are strategies for lowering the protein content, such as using less nitrogen fertiliser. Grazing animals also cause fewer emissions, since urine excreted outdoors is directly absorbed into the ground and emits less ammonia. 
The crude protein content of pig feed can be reduced if the amino acid supply is optimised through the addition of synthetic amino acids (e.g. lysine, methionine, threonine, tryptophan) or special feed components, using the best available information on "ideal protein" combined with dietary supplementation.

\section{Phase feeding, different feed for young and old animals}

- Effect on: $\mathrm{NH}_{3}, \mathrm{~N}_{2} \mathrm{O}$.

- Presence: Denmark (T), Finland (C), Norway (C), Sweden (C).

- Concerns for animal welfare: U.

A specific application of low protein feed where the protein content is lowered in the feed as the animals get older or during the lactation period.

\section{Increasing the non-starch polysaccharides in feed}

- Effect on: $\mathrm{NH}_{3}$.

- Presence: Denmark (T), Finland (U), Norway (T), Sweden (U).

- Concerns for animal welfare: no.

Increasing the level of non-starch polysaccharides (e.g. sugar, beet pulp, soybean hulls) in the feed can lower the $\mathrm{pH}$ of the excreta and thus lead to reduced ammonia emissions. However, increasing the levels of non-starch polysaccharides can also have negative effects as it can also increase the amount of waste created and lead to increased odour problems.

\section{Supplementation of $\mathrm{pH}$-lowering substances, such as benzoic acid}

- Effect on: $\mathrm{NH}_{3}$.

- Presence: Denmark (U), Finland (U), Norway (T), Sweden (T).

- Concerns for animal welfare: U.

By replacing $\mathrm{CaCO}_{3}$ in the animal feed by $\mathrm{CaSO}_{4}, \mathrm{CaCl}_{2}$, or calcium benzoate, the $\mathrm{pH}$ of urine and slurry can be reduced, which also leads to lower ammonia emissions. These methods have the potential to reduce ammonia emissions from slurry by $35-60 \%$. 


\section{Increased grazing}

- Effect on: $\mathrm{NH}_{3},\left(\mathrm{CO}_{2}\right)$.

- Presence: Denmark (T), Finland (C), Norway (T), Sweden (C).

- Concerns for animal welfare: U.

As described under previously in this section, low-protein feed might be difficult to achieve because of the high ratio of nitrogen in young grass and legumes. It has however been shown that grazing animals emit less ammonia than housed animals since the urine is directly infiltrated into the soil. This effect is maximised if animals are kept outdoors 24 hours a day. If animals are brought indoors overnight there will still be a problem of ammonia emissions from dirty floors.

\section{Adding nitrate to fodder for dairy cattle}

- Effect on: $\mathrm{CH}_{4}$.

- Presence: Denmark (T), Finland (U), Norway (N), Sweden (U).

- Concerns for animal welfare: U.

Adding nitrate to cattle feed has been shown to reduce enteric methane emissions. However, nitrate can also be toxic to animals so it is necessary to find the right dosage. There is also a risk that ammonia and nitrous oxide emissions from manure will increase.

\section{Feed that minimises emissions from digestion}

- Effect on: $\mathrm{CH}_{4}$.

- Presence: Denmark (T), Finland (T), Norway (C), Sweden (T).

- Concerns for animal welfare: U.

If cattle are fed with increased amounts of concentrate feed, fat and easily digested roughage, methane emissions can be reduced by $10 \%$. However, it is important to consider whether this will result in a total reduction in greenhouse gas emissions after taking into account the production of the feed. There may also be negative effects on animal health if the amount of roughage is reduced. 


\section{Use feed with lower climate impact during production}

- Effect on: $\left(\mathrm{N}_{2} \mathrm{O}\right),\left(\mathrm{CH}_{4}\right), \mathrm{CO}_{2}$.

- Presence: Denmark (T), Finland (U), Norway (N), Sweden (T).

- Concerns for animal welfare: no.

Soy and palm kernels are common ingredients in animal feed. These are often grown in areas with deforestation. However it is possible to substitute soya and palm kernels with more locally grown feed that has a lower climate impact.

\section{Improved productivity through healthier animals}

- Effect on: $\left(\mathrm{NH}_{3}\right),\left(\mathrm{N}_{2} \mathrm{O}\right), \mathrm{CH}_{4},\left(\mathrm{CO}_{2}\right)$.

- Presence: Denmark (T), Finland (C), Norway (U), Sweden (C).

- Concerns for animal welfare: positive.

By having healthy dairy cows without udder infections, milk production per cow will increase and emissions per litre of milk will decrease. In a similar way, the emissions per unit of product will go up if the mortality of calves and piglets is reduced.

\subsubsection{Land use measures}

\section{Restore organic soils to wetlands}

- Effect on: $\mathrm{N}_{2} \mathrm{O},\left(\mathrm{CO}_{2}\right)$.

- Presence: Denmark (T/C), Finland (T), Norway (N), Sweden (T).

- Concerns for animal welfare: N/A.

Restoring organic soils to wetlands can be an effective way to reduce nitrous oxide emissions and can potentially sequester carbon from the atmosphere. This has not been done on a large scale, but when new wetlands are created it is common to site them on organic soils. 


\section{Convert farming on organic soils to grasslands or forest}

- Effect on: $\mathrm{N}_{2} \mathrm{O}, \mathrm{CO}_{2}$.

- Presence: Denmark (T/C), Finland (T/C), Norway (U), Sweden (T).

- Concerns for animal welfare: U.

There is evidence that afforested organic soils continue to leak nitrous oxide and carbon for many decades. However, the reduced annual application of fertilizers will result in some decrease in N2O and the termination of annual tillage will result in increased carbon sequestration or at least decreased emission of $\mathrm{CO}_{2}$.

\section{Increase carbon sequestration in arable land}

- Effect on: $\mathrm{CO}_{2}$.

- Presence: Denmark (T), Finland (U), Norway (T), Sweden (T).

- Concerns for animal welfare: N/A.

Intensive production and tillage reduce soil carbon stock. However carbon stocks can also be increased by adding more terrestrial carbon, e.g. by growing cover crops, increasing the incorporation of straw and other waste products or the spreading of sludge, digested residues and manure. Another option would be to develop and grow more perennial crops.

\section{Add biochar to soil}

- Effect on: $\left(\mathrm{N}_{2} \mathrm{O}\right), \mathrm{CO}_{2}$.

- Presence: Denmark (T), Finland (T), Norway (U), Sweden (T).

- Concerns for animal welfare: N/A.

The burning of biomass under anaerobic conditions (known as pyrolysis or gasification) produces a gas consisting of, among other things, hydrogen, methane and carbon monoxide, as well as a stable form of carbon known as biochar.

Biochar added to farmland may improve the physical and biological properties of soil, thus stimulating the growth of crops, as well as reducing the leaching of nutrients.

In addition, biochar does not break down easily and could thus contribute to a long-term increase in soil carbon stocks. Dissemination of biochar on agricultural land has therefore been proposed as a measure that could bind atmospheric carbon dioxide in the soil while providing a positive impact on agriculture. There are also findings that suggest that 
biochar can reduce nitrous oxide emissions. However, the claimed benefits are very uncertain and there is a risk that it will seize huge quantities of biomass if applied on a large scale.

\section{Catch crops}

- Effect on: $\mathrm{NH}_{3}, \mathrm{~N}_{2} \mathrm{O}, \mathrm{CO}_{2}$.

- Presence: Denmark (C), Finland (T/C), Norway (C), Sweden (C).

- Concerns for animal welfare: U.

A catch crop is a crop that is sown in the existing crop. It is meant to absorb nutrients during late summer and autumn, and is then mowed into the soil. This will reduce nitrous oxide emissions and nitrogen leaching and improve the level of soil organic carbon.

\section{Reduced tillage}

- Effect on: $\mathrm{N}_{2} \mathrm{O}, \mathrm{CO}_{2}$.

- Presence: Denmark (T), Finland (C), Norway (C), Sweden (C).

- Concerns for animal welfare: U.

Reduced tillage is a quite common practice that reduces nitrous oxide emissions and increases soil carbon stocks. However, it leads to increased use of herbicides. It is more difficult to combine with organic farming since tillage is one of the few methods available for organic farmers to fight weeds.

\section{Grow more trees and shrubs on agricultural land}

- Effect on: $\mathrm{CO}_{2}$.

- Presence: Denmark (T), Finland (T), Norway (C), Sweden (N).

- Concerns for animal welfare: U.

With more trees and shrubs on permanent pastures, carbon sequestration would increase. In some cases this could increase biodiversity. As with all carbon sequestration, a new equilibrium will be reached after a couple of decades. 


\section{Increase permanent pastures}

- Effect on: $\mathrm{NH}_{3}, \mathrm{~N}_{2} \mathrm{O}, \mathrm{CO}_{2}$.

- Presence: Denmark (T), Finland (T), Norway (C), Sweden (N).

- Concerns for animal welfare: U.

Permanent pastures have a higher carbon stock than pastures that are tilled and resown regularly. However, it is important to note that the carbon stock will not continue to increase forever, but will reach a new equilibrium after some years.

\section{Land cover in winter}

- Effect on: $\mathrm{NH}_{3}, \mathrm{~N}_{2} \mathrm{O}$.

- Presence: Denmark (C), Finland (C), Norway (U), Sweden (C).

- Concerns for animal welfare: U.

Since the bulk of the annual emissions of nitrous oxide occur outside the growing season, it is possible to reduce emissions by growing plant cover in winter. Plant cover could reduce emissions so that less mineralised nitrogen is available outside the growing season, when the plants take up nitrogen from the soil for a long period of time and the nitrogen that is bound to the plants is not available to dmicrobes. Research results, which show that nitrous oxide emissions from herbage are usually lower than from grain support this theory. There is still not enough research to say how much this measure would reduce emissions.

\section{Precision farming}

- Effect on: $\mathrm{NH}_{3}, \mathrm{~N}_{2} \mathrm{O}$.

- Presence: Denmark (C), Finland (T), Norway (T), Sweden (C).

- Concerns for animal welfare: U.

This means taking into account the fact that there are differences between parcels of land and within the same parcel. It makes it possible to apply less manure or mineral fertiliser on fields that would not get a high yield anyway, and conversely increase fertiliser application on more fertile areas. In this way nitrogen efficiency can increase and nitrogen losses in the form of ammonia and nitrous oxide will decrease. 


\subsubsection{Energy efficiency measures}

\section{Increase the use of waste heat in greenhouses}

- Effect on: $\mathrm{CO}_{2}$.

- Presence: Denmark (C), Finland (T), Norway (N), Sweden (T).

- Concerns for animal welfare: U.

Many greenhouses are today heated with fossil gas. There are also many industries and power plants with unused waste heat. If more greenhouses could use waste heat and replace fossil gas, significant reductions in carbon dioxide emissions could be achieved.

\section{Build new energy-efficient greenhouses (and refit existing ones)}

- Effect on: $\mathrm{CO}_{2}$.

- Presence: Denmark (C), Finland (T), Norway (N), Sweden (C).

- Concerns for animal welfare: U.

New greenhouses are about 30\% more energy efficient than old ones. Where fossil energy is used for heating, retrofitting and replacing old greenhouses with new more energy-efficient versions reduces carbon dioxide emissions.

Use energy-efficient ventilation systems, including natural ventilation

- Effect on: $\mathrm{CO}_{2}$.

- Presence: Denmark (C), Finland (U), Norway (N), Sweden (C).

- Concerns for animal welfare: U.

Using natural ventilation systems instead of electric ventilation will reduce energy consumption. This will only lead to lower carbon dioxide emissions if electricity is obtained from fossil sources. Changes to the ventilation system could have negative effects on ammonia emissions. 


\section{Reduce energy use for grain drying}

- Effect on: $\mathrm{CO}_{2}$.

- Presence: Denmark (U), Finland (T), Norway (N), Sweden (T).

- Concerns for animal welfare: N/A.

Grain drying requires a lot of energy during a short period of the year. There are different methods to increase energy efficiency, e.g. reusing the heat through recycling of the air. Another option is to accept higher water content in grain that is only going to be stored for a short period.

\section{Reduce energy use from milking}

- Effect on: $\mathrm{CO}_{2}$.

- Presence: Denmark (C), Finland (T), Norway (N), Sweden (C).

- Concerns for animal welfare: U.

Milking is responsible for a significant share of the energy use at a dairy farm. Robot milking requires more energy than traditional milking systems. Using a heat exchanger before cooling the milk can reduce energy consumption. Depending on the energy source this can lead to reductions in carbon dioxide emissions.

\section{Replacing diesel with renewable fuels}

- Effect on: $\mathrm{CO}_{2}$.

- Presence: Denmark (U), Finland (T), Norway (T), Sweden (T).

- Concerns for animal welfare: U.

Diesel for agricultural machines represents about half of the energy consumption in agriculture. There are currently few options for replacing diesel with renewable fuels. The availability of biodiesel is limited and the total carbon savings seen from a life-cycle perspective are often questionable. At present there is no agricultural machinery on the market that is adapted to use other renewable fuels, such as ethanol and biogas. 


\subsubsection{Energy production}

\section{Increase digestion of manure to biogas}

- Effect on: $\mathrm{N}_{2} \mathrm{O}, \mathrm{CH}_{4}, \mathrm{CO}_{2}$.

- Presence: Denmark (C), Finland (T), Norway (T), Sweden (T).

- Concerns for animal welfare: N/A.

Anaerobic digestion of manure to produce biogas will reduce methane and nitrous oxide emissions, while providing biogas that can replace fossil fuels. The digest contains lower concentrations of organic material compared to manure, which could reduce carbon stocks in the soil. Another problem is that an efficient process requires biomass for codigestion. The environmental benefits may vary depending on the source of biomass.

See also case study on biogas.

\section{Biogas from biomass (e.g. maize, natural grass, conventional festulolium and organic clover)}

- Effect on: $\mathrm{NH}_{3}, \mathrm{CO}_{2}$.

- Presence: Denmark (T/C), Finland (T), Norway (N), Sweden (T).

- Concerns for animal welfare: N/A.

Biogas can also be produced from biomass alone. This will have the benefit of producing a fuel that can replace fossil fuels as well as a digest that can replace mineral fertilisers. One concern is that when this has been practised the most common crop is maize. Maize provides few benefits for biodiversity and has a very shallow root system, which in the long run will lead to losses in soil organic carbon. See also case study on biogas.

\section{Straw for fuel in CHP}

- Effect on: $\mathrm{N}_{2} \mathrm{O}, \mathrm{CO}_{2}$.

- Presence: Denmark (C), Finland (T), Norway (T), Sweden (N).

- Concerns for animal welfare: N/A.

Straw is a by-product of grain production and can be used as a renewable fuel in central heating plants. This is quite common in Denmark, but unusual in the other Nordic countries. The negative effects are that when 
straw is removed from the fields there will be a depletion of soil organic carbon in the long run.

\section{Straw for thermal gasification with reversal of biochar to soil}

- Effect on: $\left(\mathrm{N}_{2} \mathrm{O}\right), \mathrm{CO}_{2}$.

- Presence: Denmark (T), Finland (T), Norway (T), Sweden (N).

- Concerns for animal welfare: N/A.

Gasification of straw at high temperature and at low oxygen pressure produces bioenergy, as well as a stable form of bio-carbon, known as biochar, which is comparable with charcoal. By treating straw in this way, biomass can be returned to the soil and act as a very stable carbon pool. It is estimated that biochar carbon input to the soil will not degrade over a 20-100 year period due to its high stability, although this has not been confirmed. On certain types of agricultural land it is assumed that biochar will also contribute to better retention of water and increased microbiological activity that is beneficial to soil fertility.

\section{Increase production of energy willow}

- Effect on: $\mathrm{CO}_{2}$.

- Presence: Denmark (C), Finland (T), Norway (N), Sweden (C).

- Concerns for animal welfare: N/A.

Land that today lays fallow could be planted with energy willow. An increase in production of bioenergy could replace fossil fuels and reduce carbon dioxide emissions. However, there would probably be some increase in nitrous oxide emissions, since willow plantations are normally fertilised. Willow cannot be grown in the most northern regions of Norway, Sweden and Finland.

\subsubsection{Production and consumption}

\section{Decrease the number of animals}

- Effect on: $\mathrm{NH}_{3}, \mathrm{~N}_{2} \mathrm{O}, \mathrm{CH}_{4}, \mathrm{CO}_{2}$.

- Presence: Denmark (N), Finland (N), Norway (N), Sweden (N).

- Concerns for animal welfare: U.

This is a very blunt measure. From a global perspective this will only be of benefit if consumption of animal products is also reduced. However, 
for ammonia emissions that have an impact mainly at local and regional level it is obvious that some areas could see great environmental improvements if animal densities went down.

\section{Reduce meat, milk and egg production}

- Effect on: $\mathrm{NH}_{3}, \mathrm{~N}_{2} \mathrm{O}, \mathrm{CH}_{4}, \mathrm{CO}_{2}$.

- Presence: Denmark (N), Finland (N), Norway (N), Sweden (N).

- Concerns for animal welfare: U.

The effect at a global level will only be seen if it is coupled with changes in consumption. Denmark, however, produces a lot of meat for foreign markets. A reduction in production would have a positive effect on ammonia emissions. If production of animal products is reduced it is important to provide incentives for farms so they can begin to produce alternative products and find alternative incomes.

\section{Facilitate nitrogen and climate smart food consumption}

- Effect on: $\mathrm{NH}_{3}, \mathrm{~N}_{2} \mathrm{O}, \mathrm{CH}_{4}, \mathrm{CO}_{2}$.

- Presence: Denmark (N), Finland (T), Norway (T), Sweden (T).

- Concerns for animal welfare: U.

Using dietary guidelines, certification schemes and educating professionals who work with food in restaurants and public kitchens are various ways to change consumption behaviour and make nitrogen and climate-smart food more accessible.

\section{Reduce meat, milk and egg consumption}

- Effect on: $\mathrm{NH}_{3}, \mathrm{~N}_{2} \mathrm{O}, \mathrm{CH}_{4}, \mathrm{CO}_{2}$.

- Presence: Denmark (N), Finland (T), Norway (T), Sweden (T).

- Concerns for animal welfare: U.

This would have a positive effect on all kinds of emissions. However this kind of change would probably need to be induced by either a radical change in values of the majority of the population or through a fiscal measure such as taxation. It is hard to predict exactly how these changes would fall out, but most likely the reduction would not be equal for all kinds of animal products, or for domestic and imported products. 


\section{Reduce food waste}

- Effect on: $\mathrm{NH}_{3}, \mathrm{~N}_{2} \mathrm{O}, \mathrm{CH}_{4}, \mathrm{CO}_{2}$.

- Presence: Denmark (N/C), Finland (T/C), Norway (T), Sweden (C).

- Concerns for animal welfare: U.

Food is wasted at all levels of the food chain, from the field to the plate. If less food was wasted the logic would also be that less food would be produced and that would lead to lower emissions. There are various campaigns and initiatives to reduce food waste both at the production level and at a consumer level.

\subsection{Cases studies on emission-reducing practices}

In the workshops conducted in 2013 and 2014 the participants had round-table discussions on various agricultural practices that can reduce emissions of greenhouse gases or ammonia. These discussions resulted in the inventory of possible measures (see above). The following case studies give more details concerning some of these measures. The selection of these cases should by no means be seen as indicator that these are the most appropriate in the Nordic countries or have the greatest greenhouse gas reduction potential. These practices were mainly selected on the grounds that the project group wanted to study them more in detail and to share the findings of this analysis.

The first practice presented below is the acidification of slurry, which is a promising technology for reducing both ammonia and greenhouse gas emissions from slurry. This method is most established in Denmark. In the other countries it seems to be mainly on a trial basis.

The second practice describes green biomass as fodder with a potential to reduce climate impact.

The third practice describes the process, pros and cons of producing biogas from fluid animal manure. This measure is also listed in chapter 6.2 on the inventory of measures to reduce the environmental and climate impact of agriculture.

\subsubsection{Case study on acidification of slurry in Denmark}

Acidification is a technology for reducing both ammonia and greenhouse gas emissions from slurry, which may take place through different methods. Organic farming does not allow the use of artificial chemicals 
to acidify slurry, but lactic acid bacteria may be allowed if the demonstration results are promising.

\section{The technology}

The conversion of ammonium $\left(\mathrm{NH}_{4}{ }^{+}\right)$into ammonia $\left(\mathrm{NH}_{3}\right)$ is $\mathrm{pH}$ dependent. The acid reduces the $\mathrm{pH}$ and the chemical equilibrium between $\mathrm{NH}_{4}{ }^{+}$ and ammonia $\mathrm{NH}_{3}$ is changed in favour of $\mathrm{NH}_{4}{ }^{+}$. As only $\mathrm{NH}_{3}$ evaporates, the $\mathrm{pH}$ of the slurry is a determining factor for the amount of ammonia that volatilises in the housing system, during storage and during application to fields.

Normally, slurry has $\mathrm{pH}$ values of about 7 or 8 . Reducing the $\mathrm{pH}$ to about 6 decreases $\mathrm{NH}_{3}$ emissions significantly.

Methane, $\mathrm{CH}_{4}$, is produced from organic matter by microorganisms (methanogenesis) and when $\mathrm{CH}_{4}$ is formed it evaporates. The process is inhibited at lower $\mathrm{pH}$, hence acidification will also reduce the formation of $\mathrm{CH}_{4}$.

Acidification of slurry can take place in stables, in slurry tanks or immediately before application. Methane emissions in particular are dependent on where the acidification takes place, and the biggest emission reductions are achieved if acidification is done in the stables (this is also potentially beneficial for the animals due to reduced ammonia concentration in the stables). There is no effect on methane emissions if the acidification takes place immediately before application.

\section{The potential}

Acidified slurry is not suitable for biogas production. A number of factors, such as dry matter content, geographical distribution and animal farm sizes, must be considered when choosing acidification as a means to reduce ammonia and greenhouse gas emissions instead of, for example, choosing biogas production. A clear preference for one method over the other is however difficult because scientific documentation is limited and because it depends on an almost unlimited number of factors. For instance, it is also necessary to consider the $\mathrm{pH}$ of the soil where the slurry is to be applied.

Acidification of the digestate from a biogas plant may also have a positive impact on the emission of methane and ammonia. The $\mathrm{pH}$ of slurry increases during the fermentation process in the biogas plant and methane evaporation can be high in the final storage because the population of methane-producing microorganisms is rather large. Apparently, acidification of the digestate has never been subject to a detailed investigation. 
Establishment of acidification plants is mainly feasible when new stables and storage tanks are constructed.

\section{Ammonia}

Acidification of porker slurry in stables is (based on evidence from trials) expected to reduce ammonia evaporation by about $65-70 \%$ depending on the construction of stable floors (Danish Environmental Agency 2009a). Regarding cattle, the reduction is expected to be about $50 \%$ in loose housing systems with bed compartments and slatted floors in the walkways (Danish Environmental Agency 2009b).

Acidified slurry will improve the fertilising characteristics of the slurry (less $\mathrm{NH}_{3}$ evaporation and more $\mathrm{NH}_{4}{ }^{+}$which is the nitrogen compound accessible by plants). This is however not included in Danish nitrate utilisation efficiency demands. It is therefore unlikely that Danish farmers will use less chemical fertiliser when using acidified slurry - and consequently nitrogen evaporation and leaching will not be reduced.

\section{Greenhouse gases}

Scientific documentation on the greenhouse gas reduction potential is limited, but trials have been carried out showing considerable potential.

The methane reduction can be higher than $90 \%$, measured in a Danish pig farm during a storage period of three months (Olesen et al., 2012). However it seems to be the norm to use reduction rates of $60 \%$ in Danish scenarios proposing acidification of slurry (e.g. DCA, 2013, and Olesen et al., 2012).

Olesen et al. (2012) state that acidification reduces the conditions for (but does not exclude) the formation of a floating layer on cattle slurry, which may increase evaporation of nitrous oxide $\left(\mathrm{N}_{2} \mathrm{O}\right)$ during storage. The reference does not explain why. On the other hand, the decreased evaporation of $\mathrm{NH}_{3}$ should result in decreased evaporation of $\mathrm{N}_{2} \mathrm{O}$. The Danish Environmental Agency assumes no (or insignificant) effects from the reduced floating layer.

\section{Environmental impact}

Sulphuric acid is aggressive and can damage buildings and machinery in contact with slurry that is acidified with the acid. Lactic acid bacteria do not have the same aggressive characteristics.

Sulphur, which is a micronutrient, is lacking from many soils. Lamers et al. (1998) describe, however, how sulphate pollution may mobilise extra phosphate and ammonium as well as induce phytotoxicity in wetlands and thereby induce major changes in vegetation com- 
position. The application of slurry that is acidified with sulphuric acid may therefore be environmentally harmful, especially when applied close to streams or lakes.

Most soils have a relatively high $\mathrm{pH}$ buffer capacity. In the long run, soil eventually has to be limed.

There is energy consumption related to the process estimated to be in the order of $3 \mathrm{kWh}$ per $\mathrm{m}^{3}$ of pig slurry (2009a) and $1 \mathrm{kWh}$ per $\mathrm{m}^{3}$ of cattle slurry (2009b). The negative environmental impact of energy and material consumption to build and operate the plant is considered to be much smaller than the positive impact from avoiding emissions of ammonia and methane.

According to Loehr-Petersen (2010) acidification has a corrosive effect on calcium and magnesium compounds in soils, which can have a negative impact on the soil structure. In Denmark, acidification plants using sulphuric acid $\left(\mathrm{H}_{2} \mathrm{SO}_{4}\right)$ have been implemented at more than 80 cattle and pig stables but there are a number of other acidification technologies available on the market. In Sweden, slurry acidification seems mainly to be on a trial basis.

The Danish Knowledge Centre for Agriculture has started up an experiment using lactic acid bacteria to acidify slurry. The hypothesis is that the effect can be as good as using sulphuric acid.

\subsubsection{Case study on green biomass as fodder ${ }^{14}$}

Today the main use of green biomass is as feed for ruminant animals. However, when biorefined, the protein-rich fractions can eventually also be used as fodder for non-ruminant animals. Feed protein concentrates are easy to handle and transport, and other fractions of the biorefining process can find other uses, e.g. production of biogas, chemicals and insulation materials. Some crops (especially grass crops) have a long growing season and can use photosynthesis for a longer period of the year than other crops, thus these crops can provide high yields. In addition, nitrogen leaching is in many cases relatively low.

Green biomass may constitute green grass from the cultivation of permanent grassland, set-aside agricultural land, nature conservation areas and green crops such as alfalfa, clover and immature cereals. Many

${ }^{14}$ Authors: Bente Hessellund-Andersen and Jacob Sørensen, NOAH. 
of the crops have a potential for low nitrogen leaching because of their roots and the long growth season.

Biorefining has until now mainly been used for production of ethanol for transport proposes. This process is increasingly criticised, partly because the production of biomass for energy competes with the production of food for humans and fodder for domestic animals. The green biorefinery (GBR) concepts may be more acceptable. However, at the moment the technology is immature and it is uncertain whether it has been tested on non-ruminant animals.

\section{The technology}

The first essential processing step is mechanical separation using an extrusion press. This fractionation makes a liquid (press juice) and a solid (press cake) available for further product refining steps. The press juice contains high concentrations of proteins and can be used to produce feed protein concentrates by using technologies such as heat coagulation or ultrafiltration. After protein extraction, the remaining juice can, for example, be used in a biogas plant because of its relatively high concentration of carbohydrates. The press cake may be utilised in a biogas plant, as livestock feed (green feedstuff pellets) or for fibre applications, e.g. insulation.

The recoverable quantity of the products is determined by many factors, such as the species composition, harvest time and choice of GBR technology.

The protein concept in Höltinger et al. (2014) shows high production of fodder and low energy surplus, whereas the amino acids concept shows a high surplus of energy, high production of amino acids (used mainly as additive to fodder) and low production of fodder. The process uses relatively high amounts of process energy. It seems however that in most cases the process will produce more energy than is used by the process. Energy for transportation is apparently not included.

Using grass silage in GBRs instead of in biogas facilities will most likely lead to more centralised structures with fewer but larger plants, because the capital cost to establish a GBR is significantly higher than that for setting up a biogas plant. The more centralised structures of GBRs also lead to significantly higher transportation distances. For instance, establishments of GBRs in Austria will result in mean transportation distances of 43-48 km, compared to $16 \mathrm{~km}$ for biogas plants (Höltinger et al. (2014)). 


\section{The potential}

To give an idea of the potential of GBR fodder production, we show yields of press juice estimated by Höltinger et al. (2014), which they use to assess the techno-economy of the GBR protein concept. It seems that the data mainly comes from the already operating pilot Demonstration Plant Havelland. Optimisation of the process can therefore be expected in the future.

\begin{tabular}{|c|c|c|c|c|}
\hline & $\begin{array}{r}\text { Content } \\
(\mathrm{kg} / \mathrm{t} \mathrm{dm} \text { juice })\end{array}$ & $\begin{array}{r}\text { Process yield } \\
\text { (\%) }\end{array}$ & $\begin{array}{r}\text { Product purity } \\
(\%)\end{array}$ & $\begin{array}{r}\text { Product output } \\
\text { (kg/t dm biomass) }\end{array}$ \\
\hline Feed protein & $110-250$ & $45-60$ & 50 & $9.9-60.0$ \\
\hline White protein & $10-30$ & $45-60$ & 90 & $0.5-4.0$ \\
\hline Lactic acid & $330-450$ & $90-100$ & 88 & $33.8-102.3$ \\
\hline
\end{tabular}

White protein concentrates have potential applications in cosmetics and food industry. The green biomass is feedstocks such as alfalfa, clover and grass. Press juice production is $100-200 \mathrm{~kg} \mathrm{dm} / \mathrm{t}$ dm biomass (Höltinger et al. (2014)).

This can be compared with this table 7 on yields in protein, lysine, methionine and vitamin E:

Table 7: Yields in protein, lysine, methionine and vitamin $\mathrm{E}$

\begin{tabular}{|c|c|c|c|c|c|c|}
\hline & $\begin{array}{l}\text { Yield } \\
\text { t/ha }\end{array}$ & $\begin{array}{r}\text { Protein } \\
\%\end{array}$ & $\begin{array}{l}\text { Protein } \\
\text { kg/ha }\end{array}$ & $\begin{array}{r}\text { Lysine, } \\
\mathrm{kg} / \mathrm{ha} \\
\text { (\% of total protein) }\end{array}$ & $\begin{array}{r}\text { Methionine } \\
\mathrm{kg} / \mathrm{ha} \\
\text { (\% of total protein) }\end{array}$ & $\begin{array}{r}\text { Vitamin E } \\
\text { g/ha }\end{array}$ \\
\hline Soya & 2 & 35 & 700 & $43(6.14)$ & 9 (1.29) & 30 \\
\hline Rapeseed & 5 & 20 & 1,000 & $60(6.00)$ & $20(2.00)$ & 75 \\
\hline Peas & 6 & 22 & 1,300 & $92(7.08)$ & $13(1.00)$ & 50 \\
\hline Wheat & 9 & 11 & 1,000 & $30(3.00)$ & $16(1.60)$ & 90 \\
\hline Clover & 13 & 12 & 1,500 & $120(8.00)$ & $52(3.47)$ & 600 \\
\hline Red clover & 12 & 21 & 2,600 & 200 (7.69) & $90(3.46)$ & 600 \\
\hline Meadow grass & 3 & 12 & 350 & $25(7.14)$ & $12(3.43)$ & 100 \\
\hline
\end{tabular}

The average soya yield from the 20 biggest global producers is about $2.3 \mathrm{t} / \mathrm{ha}$. Data is from 2005 (DCA (2013)).

With a feed protein process yield of $45-60 \%$ the table shows that many crops have the potential to produce more feed protein per hectare than soya.

Using Austria as a model, Höltinger et al. (2014) have shown that the green biorefineries are economically viable under favourable market conditions even without policy support measures. CONCITO (2014) concludes the same: Preliminary estimates show reasonable economy in extracting proteins from green biomass. 


\section{Greenhouse gas impacts}

The import of soya to Denmark entails a net emission of greenhouse gases and soya cake of between 2 and $3.8 \mathrm{CO}_{2} \mathrm{e} / \mathrm{kg}$ soya, according to CONCITO (2014). Danish imports are very high and correspond to emissions in the order of 6 million tonnes $\mathrm{CO}_{2} \mathrm{e}$ /year.

We do not have good estimates of the total climate impact of producing biorefined fodder in the Nordic countries. However, it seems that it will be lower than the impact of soya, since yields are higher and transport distances are shorter. Localised production may also result in reduced land use change effects because regional production circles will have smaller impacts on global land use than global production circles.

\section{Ammonia}

The biomass considered has a long growth season, hence leaching of ammonium $\left(\mathrm{NH}_{4}{ }^{+}\right)$will be low. Regarding ammonia leaching, see internal data below (p. 6).

\section{Environmental impacts}

Increased production of green biomass can result in a demand for increased fertiliser input, as the quality of fertiliser that can be returned to the soil after GBR may be poor. However, if more nitrogen-fixing leguminous crops are involved, it may have the opposite impact, especially if the area of land used for grain production is reduced.

Preservation of biodiversity is also an issue that should be addressed in an assessment of the environmental impact. In a situation where natural grassland is not grazed by animals, it may lead to increased biodiversity if the vegetation is harvested for GBR (a similar result can be achieved by harvesting it for hay). Biodiversity in soil and vegetation would also increase if fields of grain were substituted by perennial grass etc.

\section{Application in the Nordic countries}

If Nordic countries were more self-sufficient in fodder, the demand for imports of fodder from abroad would decrease and Nordic animal production would occupy less land on other continents. Increased Nordic production of fodder could also lead to changed land use, with increased perennial grassland, decreased grain production - and eventually decreased animal production. 


\subsubsection{Case study on biogas production in Denmark ${ }^{15}$}

\section{Feasibility}

Producing biogas from fluid animal manure has ample advantages:

- Biogas can be an important element in the future energy system as fuel to generate electricity when there is no wind, or it can create high-temperature heat for industry and energy for transportation.

- Compared to present management of manure/slurry, increased biogas production can reduce greenhouse gas emissions.

- The digestate is easier to handle as a fertiliser than untreated manure as it is more concentrated and the process makes nutrients more easily accessible to crops compared to the non-digested manure.

- The organic waste fractions from e.g. households and public kitchens can be used in the process and nutrients can be recycled, as much of the phosphorus will stay in the digestate.

- Biogas production also reduces the odour problems of slurry application.

There are however also drawbacks when the aim is to achieve sustainable agriculture that respects the wider aspects of the environment and animal welfare:

- Manure, especially slurry, is limited in sustainable agriculture. Animal production entails an environmental impact much higher than the production of most other foods.

- Biogas plants run more efficiently and are economically more profitable if organic material is added to the slurry. Presently, Danish biogas production is largely dependent on either organic waste from the food industry or maize. In sustainable agriculture, total biomass resource is limited and its use for biogas has some problematic side effects regarding direct and indirect land use changes as well as soil carbon depletion. For instance, the use of straw in agro-industrial processes (heat and power, biofuels and green refining) is increasing, although straw is an important element in building up the humus and carbon content in the soil. Many experts predict that the use of straw

${ }^{15}$ Authors: Bente Hessellund-Andersen and Jacob Sørensen, NOAH. 
will increase in the vaunted future of bio-economies. Furthermore, there has long been competition for the best organic waste fractions from industry, such as slaughterhouse waste.

- Use of organic waste as additional input to manure can have some problematic side effects regarding contamination from harmful chemical compounds, which are spread when the digestate is used as fertiliser.

- It is expensive to establish the plants and therefore it will promote a tendency to maintain or increase the size of industrial-scale animal production.

- The evaporation of $\mathrm{NH}_{3}$ seems to increase as the $\mathrm{pH}$ rises.

A holistic approach to biogas production and its pros and cons is essential, and societal strategies regarding energy production, land use, waste and resource efficiency should all be included in decisions regarding the establishment of biogas plants.

The climatic benefits of biogas technology are uncertain because the effects on emissions of $\mathrm{CH}_{4}$ and $\mathrm{N}_{2} \mathrm{O}$ as well as soil carbon are only sparsely documented (Petersen and Olesen, 2011).

\subsubsection{Technology and processes}

\section{Slurry}

In Denmark, most manure is slurry (i.e. a mixture of urine and faeces). Manure from grazing livestock is not available for biogas plants. Furthermore, it is not practical to use manure from cattle walking on sandy floors and acidified slurry cannot be used in larger quantities.

The potential for using slurry for biogas depends also on other aspects, such as dry matter content and geographical distribution as well as the quantity of the slurry:

- The dry matter content of slurry from sows is rather low and in many cases it is not suitable for use in biogas. In Denmark the proportion of slurry from sows is increasing and has now reached $30 \%$ of total pig slurry production as more and more piglets are exported.

- Biogas plants will normally collect slurry from a number of farms. If the distance between the delivering farms and the plant gets too big, it will neither make economic nor environmental sense. 
- It may not pay to pick up manure from small farms. 16\% of Danish manure is produced on farms that can supply less than one truck full a week.

The Danish Energy Agency (2014a) assesses that two thirds of the collected slurry in Denmark can be used in biogas plants.

\section{Deep litter}

In Denmark, deep litter, mainly from dairy cattle and chickens, constitutes about $9-12 \%$ of the total manure and $35 \%$ of total dry matter. Organic farming has approximately the same division between stable types as conventional farming and the share between slurry and deep litter will be approximately the same (Munk, 2014). The stable has to be emptied a few times each year. The deep litter is scraped together and either placed in temporary storage or spread directly on the fields. It is best to apply the deep litter on the land before sowing in the spring where it can also be mulched into the soil. Furthermore, the utilisation efficiency of nitrogen is low (45\%) compared to slurry (65-70\%). However, animal welfare is better in stables using deep litter compared to other stables.

Because deep litter has a high content of dry matter and because the mechanical influence of the animals' stamping makes the straw more degradable, it is suitable for mixing with slurry in a biogas plant. It can increase gas production and the farmer can avoid applying deep litter to the fields.

Compared to the application of digestate on fields, application of deep litter probably results in higher emissions of $\mathrm{NH}_{3}$ due to the relatively lower utilisation rate of the nitrogen content.

Another important aspect concerning advantages and disadvantages of utilising deep litter in biogas facilities is its effect on the humus balance in the soils. It is difficult to say whether unprocessed or digested deep litter is best to build up humus in soils (see discussion of soil structure below).

A disadvantage of using deep litter for biogas is the need to establish new storage capacity.

\section{Organic waste}

Organic waste can be utilised as additional biomass input. It increases the energy output in biogas systems based on manure and has the potential to increase the recycling of nutrients from society to agriculture. Organic waste from households, restaurants, catering kitchens and byproducts from food production or from the harvest as well as other notmarketable units can be used in the biogas production. The most obvi- 
ous industrial waste components, e.g. slaughterhouse waste, are already used to the full in Danish biogas plants or for other objectives.

Depending on other potential uses of an organic waste fraction, it may be utilised for biogas production. For instance, if a type of waste had no prior feed or food use, its use will not reduce food production but can instead contribute as a nutrient supply for crops by using the digestate as fertiliser. However, the waste could alternatively have been composted and used as both a fertiliser and a soil conditioner. And if biogas production from waste is profitable, it might bias waste-intensive production (including production in which little is done to decrease the mortality rate of animals) towards production with low levels of waste creation (and a lower mortality rate).

Sewage sludge is also used as a source for biogas production but not mixed with agricultural sources.

If agriculture is to recover the nutrients from waste and sewage sludge, it will imply the use of waste and wastewater free from harmful substances such as heavy metals and troublesome chemical compounds. Non-polluted waste is however difficult to achieve in reality and much depends on politically determined limits for the problematic substances. Cleaning of the digestate (bioliquid) is an option that is being examined now. A better long-term solution would be to clean up the production process and improve the separation of organic and inorganic waste at source.

\section{Energy crops}

Crops such as maize, beet, grain, grass, clover grass and Jerusalem artichoke can be mixed with manure to increase methane production and to improve the economic yield of the plants. In Denmark, this practice has increased, since the most suitable organic waste is already used.

There are however obvious problems with using crops for energy production, e.g.:

- Production of the crops causes pollution, e.g. greenhouse gases and pesticides (except in organic farming).

- The area used can lead to increased direct and indirect global land use (LUC and ILUC).

- Bigger demand for crops, i.e. higher food prices.

- In the long run growing leguminous plants and grass can preserve and improve soil properties, whereas growing annual energy crops undermines and destroys soil properties. 
There has been criticism in Denmark that the climatic benefits of making biogas in most cases disappear when crops are used in biogas plants if all factors (including ILUC factors) are included in the calculations. The emissions may in fact increase (see e.g. Bredsdorff, 2012). Consequently, the Danish government wishes to decrease the use of energy crops for biogas production. With effect from 2015 the Danish support scheme for biogas production will therefore be based on the amount of energy crops used. If the input of energy crops gets too big the support will be withdrawn.

\section{Straw}

In Denmark, about $30 \%$ of straw is used for feed and bedding, about $30 \%$ is used for CHP (combined heat and power), and the remaining $40 \%$ or so is left on the fields.

The energy output of straw in a biogas plant is only about half that when burned in a CHP plant. However, the biogas digestate has better nutritional characteristics than the ash from CHP plants.

Danish biogas units have focused on industrial waste and been reluctant to use straw. Straw is slow to digest and has caused technical problems for many plants as it can form a floating layer in the biogas reactor. It appears that straw digestion has never been demonstrated in a fullscale plant. Nevertheless, the Danish government expects a rather huge increase in the use of straw in Danish biogas production in the coming years as a few experiments have shown good results. The expectation is that straw (as well as deep litter) will make up for the reduction in use of energy crops from 2015 (see above).

Since 1989 there has been a ban on straw burning on agricultural land in Denmark. Agricultural researchers have since then followed the development of soil carbon where the straw has been burned, collected or mulched. Their results have shown increased soil carbon when the straw is not burned or removed (Aarhus University, 2011). More recently, researchers have been discussing the scientific limit for organic matter in the soil (the so-called Dexter index) and the possibilities of compensating for the loss from collection of straw by growing catch crops or by growing grain with longer straw (Gylling et al., 2012).

Using straw for the production of biogas is also related to the discussion about soil structure and the importance of a living soil that is not degraded by lack of organic material, as well as the retention of soil carbon (soil as a "carbon sink"). 


\section{Catch crops}

Catch crops (sown after harvesting the main crop to prevent nitrogen leaching by incorporating excess nitrogen from the soil) are not in direct competition with food production. Harvesting of these crops (instead of mulching) can therefore increase the available amount of additional biomass for biogas production. The digestate can be used as fertiliser. However, this may eliminate some of the benefits related to soil organic matter that would result from mulching.

Leguminous plants such as alfalfa and clover are grown for nitrogen fixation (especially on organic farms) sometimes in combination with grass. On stockless farms, where use of these crops as fodder is not an alternative, harvesting for biogas production may improve the farmer's income. Biogas digestion will improve nutrient accessibility, as the digest will have similarities to artificial fertilisers (easily accessible nutrient at the right time). Using fertiliser-like products is in contradiction to the normal practice in organic farming, where it is considered a value not to force plants to grow too fast in order to make the plants more resistant to pests.

\subsubsection{Environmental impact}

\section{Greenhouse gas}

When slurry is produced, stored in slurry tanks and applied to agricultural land, $\mathrm{CH}_{4}$ and $\mathrm{N}_{2} \mathrm{O}$ are released into the atmosphere. The same applies to other types of manure. If the manure is fed through a biogas plant a good share of the carbon content is broken down to $\mathrm{CH}_{4}$ and eventually to $\mathrm{CO}_{2}$ through an oxidisation process (one molecule of $\mathrm{CO}_{2}$ affects the climate 25 times less than a $\mathrm{CH}_{4}$ molecule). $\mathrm{N}_{2} \mathrm{O}$ emissions from storage and fields will also be reduced compared to a situation where manure is handled without degassing.

The greenhouse gas balance also includes changes in the carbon stock of the soil (see discussion on soil humus below).

\section{Nitrogen}

Dry matter containing organically bound nitrogen is degraded when manure is processed in a biogas plant. This means that the resulting substrate has a lower content of organically bound nitrogen and a higher content of inorganically bound plant-available nitrogen (ammonium). This can increase nutrient utilisation of the nitrogen in the manure, reducing nitrate leaching because more nitrogen is absorbed by the plants 
in the growing season compared to the use of untreated slurry (Petersen \& Jørgensen, 2008).

The $\mathrm{pH}$ of the biogas slurry increases during fermentation in the tank. This is one reason why higher $\mathrm{NH}_{3}$ losses can be expected from biogas digestate than from conventional animal slurries under the same environmental conditions ( $\mathrm{Ni}$ et al.). Many environmental factors influence the extent of $\mathrm{NH}_{3}$ evaporation and it has not been possible to give a proper general estimate of the difference between untreated and biogastreated slurry/manure.

\section{Soil structure}

Typically, around $40-50 \%$ of the carbon in the substrate is broken down to methane or carbon dioxide and removed with the biogas. Thus, less carbon may be stored in the soil when the digestate is applied to the soil compared to a situation without biogas production. It is however often argued that it is predominantly the easily degradable carbon compounds that are broken down to methane or carbon dioxide, while it is the persistent carbon compounds, such as lignin, that remain in the digestate. Persistent carbon compounds are especially important in the formation of humus.

Organic and biodynamic famers disagree on the appropriateness of using leguminous crops for biogas. To some extent organic farmers are in favour, while biodynamic farmers argue that composting results in a better soil.

When nitrogen is more easily accessible to plants in the digestate compared to compost, digestate will fertilise the plants better than compost, resulting in reduced availability of nutrients for soil microorganisms, which are essential in the formation of humus (Loehr-Petersen, 2010). The nutritional value of crops is also considered to be inferior by biodynamic farmers when the crops are fertilised with digestate instead of compost. According to Loehr-Petersen (2010).

Experiences relating to soil texture and nutritional quality are so negative that the international association for biodynamic farmers, DEMETER, is considering a ban on the construction of biomass plants on biodynamic farms (Loehr-Petersen, 2014 (personal communication)). In particular, it is the deterioration in nutritional quality - measured with a biodynamic, integrated approach - that motivates the biodynamic association to distance itself from biogas digestate as a fertiliser on biodynamic farms (Loehr-Petersen, 2010). 
According to Sustaingas (2013), neither livestock nor stockless farmers need worry about changes to their soil's humus content following the use of digestate. The carbon fraction responsible for humus generation largely remains in the digestate. 


\section{Conclusions}

\subsection{Main findings}

The two main goals of the project were firstly to present the status quo or baseline data and information regarding the Nordic agricultural sector, its greenhouse gas and ammonia emissions, the regulatory framework, support systems, and conflicts of interest. Secondly the report aims to describe paths towards an agricultural system that contributes to achieving the applicable climate targets set at international and national levels.

In this context, the report demonstrates that greenhouse gas emissions (nitrous oxide, methane and carbon dioxide) and ammonia from the agricultural sector are significant in all the Nordic countries, although not that significant in comparison with all other sectors. The share of greenhouse gases (methane and nitrous oxide) produced by agriculture in the Nordic countries is 8 and 9\% respectively in Norway and Finland, whereas it is as high as 13\% in Sweden and 19\% in Denmark. The share of emissions is substantially higher in all the countries when emissions from land use, land use changes and energy consumption are included. When these emissions are included, the share is as high as $27 \%$ in Denmark. More emissions are connected to imported goods used in agriculture, such as feed and fertilisers.

Ammonia emissions are another culprit for emissions from the agricultural sector, accounting for as much as $96 \%$ of the total emissions of ammonia in Denmark and approximately $90 \%$ on average in the Nordic countries. Livestock manure is the main source of all ammonia emissions in the Nordic countries ranging between 80 and $90 \%$ for all the countries. These levels are unlikely to drop significantly without the right measures and policies being put into place.

Nitrous oxide emissions from agriculture are the highest in Denmark, at $90 \%$, whereas the smallest share is found in Finland. All the countries, except Norway, have seen a reduction in nitrous oxide emissions, which is partly due to decreased use of nitrogen fertiliser. Methane emissions have remained steady or only reduced slightly during the past 20 years. Emission reductions from a lower number of ruminants in Denmark and Finland seem to be offset by increased emissions due to the transition 
from solid manure systems to slurry systems, which highlights the importance of more sustainable manure management practices. Some of the technical and management measures that could limit emissions, such as keeping animals indoors, are unlikely to be in the animals' best interests nor to provide high-quality, nutritious food products. As regards carbon emissions, most of these are from arable land and organic soils. Regulations controlling the burning of straw in fields and limiting use of organic soils for farming are helping to bring down carbon emissions somewhat. The inventory set out in chapter 6 of this report demonstrates that there is a whole arsenal of organisational, technical and management measures that can be used to control and reduce emissions, ranging from manure and slurry management to more carbonneutral farming practices, fertiliser management and the production of biogas from agricultural waste inputs.

Although the Nordic region to a large extent is culturally, social and economically homogenous, the fact that the agricultural structures, topographic and climate conditions, land use and production figures differ between the countries makes it difficult to come up with a onesize-fits-all formula for setting up farming systems that have significantly lower emissions and less impact on climate change.

Some common trends and factors stand out though, and these are worthy of more research, the exchange of good practices and overall Nordic cooperation. Firstly, the Nordic countries have a clear wish to strive towards agricultural and food systems that are sustainable, and there is at least a partial wish to move towards more self-sufficiency, limiting agricultural imports.

In all the countries, initiatives are being taken to help define new consumption policies and dietary guidelines. Sweden has already defined dietary recommendations that support climate-friendly diets and agricultural systems. Self-sufficiency, with reduced imports of cheaper grains and meat, may be possible for the Nordic region as a whole if consumption patterns and trade patterns are changed.

Secondly, all the Nordic countries struggle with the negative consequences of demographic change, with an ageing farming population coupled with very low employment rates $-2-3 \%$ of the total workforce - in the agricultural sector. The average age of those engaged in the employment sector is around 50 years old. The Nordic countries realise that effective policies and measures, especially financial incentives, are necessary to attract younger people to the farming sector.

Thirdly, the Nordic countries have seen a larger degree of modernisation and rationalisation of their agricultural systems. For instance, one 
common tend is a reduction in the number of dairy herds but an increase in yield per milk cow. The number of farms with cattle has also decreased greatly in the Nordic countries, leading to increased demand for imported meat in some cases. Another general trend is a decline in the production of beef in favour of poultry and pork. From a climate change point of view, this shift away from beef towards pork and poultry could be perceived as promising. However, the consumption of beef is still high, through imports. In practice this means that emissions are simply exported.

Fourthly, all of the Nordic countries are grappling with the fact that the current support systems in place for the farming sector are not fully supportive of a paradigm shift towards sustainable and self-sustaining farming that minimises climatic and environmental impact. Bottlenecks and conflicts of interest are serious obstacles. For instance, the present support systems for agriculture have mainly favoured more intensive and large-scale farming, partly due to the fact that large-scale and intensive farmers have often been better represented by the sector's interest organisations. Another fact of significance is that growth in production has historically been central to agricultural policy, while other interests were subordinated. Furthermore, the present support systems do not fully take into account the external environmental and health costs that the emissions from agriculture cause. The use of market-based or fiscal measures such as fees and taxes in agriculture is limited in that emissions are often diffuse and difficult to measure.

All the countries see a number of conflicts of interest that directly or indirectly are counterproductive of an agricultural sector with lower greenhouse gas and ammonia emissions. For instance, keeping animals indoors to limit emissions from manure and slurry is probably not in line with principles of animal welfare nor with cultural preferences for open landscapes grazed by cattle. Other important conflicts include the limitations of farmers' income and the demand for cheap bulk food some of it imported - versus locally produced quality food - often a bit more expensive. Although it is important to accept the limiting context of free trade and overall challenges of globalising agricultural production we need to address and solve as many of these conflicts of interests as possible.

In order to achieve a paradigm shift in agricultural systems, production and consumption we need to look at the system in its full complexity, illustrated through integrated systems analysis in the causal loop diagrams in chapter 5 . This systems analysis points to the central importance of what we refer to as the "environmental and social aware- 
ness" of the public. Theoretically, in a transparent and working democracy, increased public awareness would lead to the internalisation of the environmental costs associated with intensive farming, a revision of the subsidies system that promotes low agricultural product prices, and a re-evaluation of consumer choices regarding the consumption of crop and animal products. However, in practice more measures and awareness-raising are necessary to achieve this internalisation of environmental costs and to achieve a paradigm shift in agricultural production and consumption of agricultural products.

\subsection{Lessons learned}

- Practices that work in one country may work in another, and increased understanding of how the agricultural sector has developed in the different Nordic countries - and how this has influenced the sector's impact on the climate - can give valuable insights for developing solutions that can reduce emissions from agriculture and enhance carbon sequestration. We find that such knowledge is currently lacking across the Nordic countries and that the "Nordic public" are therefore dependent on the information that the big farmers' and foresters' organisations deliver.

- There is an increasing need for a better understanding of conflicts of interest that are limiting the playing field as a result of various technical, organisational and policy measures. We need to do more research into these conflicts to be able to strike the right balance between the various interests. This balance should be based on various parameters, e.g. the total emission savings of each measure, the cultural and social context, and ethical values.

- The emission reductions, policies and tools that are used are largely dependent on local conditions, consumption patterns, the overall policy context, and the balance between imports and exports of agricultural produce.

- More incentives are needed to promote greenhouse gas reduction measures at farm level. Many of the farms are of smaller size and the individual farmer cannot be expected to take rather expensive measures to contain emissions. 
- More measures and awareness-raising are necessary to achieve an internalisation of environmental costs and to achieve a paradigm shift in agricultural production and consumption of agricultural products.

- Other ways - with less environmental impact (e.g. organic/ biodynamic agriculture or permaculture) - to produce crops exist and should be developed further including via research and extended financial support.

- Highly mechanised large-scale crop production is a precondition for industrial animal production and the related cause of the current high emissions from agriculture. Hence there is a need to review agricultural support schemes.

- There is a need for more dietary guidance not only based on health parameters but also on the diet's implications for emissions levels and contribution to achieving climate change targets. In this regard, Sweden is taking the lead with clear recommendations, including advice to eat less red meat.

\subsection{Preliminary recommendations}

As this report is one output and milestone in the overall project, it is still early to make concrete recommendations. However, it is possible to make preliminary recommendations that will lead into the next phase of the project with a series of national seminars and scenario cases:

- All countries need to have an adequate regulatory framework comprising manure management, promote the increase of soil organic carbon, limit the use of organic soils for farming to help bring down carbon emissions, develop and promote practices for covered storage for manure to limit the fermentation process and reduce emissions. Put research into smaller systems and systems that work for deep litter.

- Further explore whether to extend use of the measures set out in the inventory in chapter 6. Particularly underused are measures related to energy-efficient use, energy production from agricultural input, production and consumption. Some of these measures take place at farm level whereas others (especially measures relating to production and consumption) require action at a political level. 
- We need to give incentives for agroecology with a view to increasing soil organic carbon, look for more autonomy in animal alimentation (more local production, less imported soya and grains), and develop methanisation.

- Strive towards a paradigm shift in how we perceive agricultural production, food systems and consumption with a view to striking a balance between various dilemmas and conflicts in production systems, the import/export balance, consumption patterns, and how we perceive efficiency in the farming sector and take into account environmental and climate impact factors. Agricultural and food production systems should minimise their impact on climate change, whilst ensuring safe and nutritious agricultural products and the highest possible standard of animal welfare.

- Start working towards an integrated food and agriculture policy that also takes into account global concerns regarding poverty and unequal access to food. Nordic policies should not be in conflict with such global concerns, in line with FAO guidelines and other relevant international policies and recommendations. 


\section{Tables and figures}

\section{Tables}

Table 1: Participants in this project and main authors of the report.

Table 2: Greenhouse gas emissions for 2012 (in million tons $\mathrm{CO}_{2} \mathrm{e}$ ) as reported to the UNFCC

Table 3: Manure regulations in the Nordic countries.

Table 4: Agri-environmental measures in the rural development plan for mainland Finland for 2014-2020 that affect air pollution and climate emissions.

Table 5: Measures eligible for environmental support.

Table 6: Assumed product yields of press juice for the GBR protein concept.

Table 7: Yields in protein, lysine, methionine and vitamin $\mathrm{E}$.

\section{Figures}

Figure 1: Nitrous oxide emissions (thousand tonnes) in 2012 (UNFCCC).

Figure 2: Nitrous oxide emissions (thousand tonnes) from agriculture 1990-2012.

Figure 3: Methane emissions (thousand tonnes) in 2012.

Figure 4: Methane from agriculture 1990-2012.

Figure 5: Methane from agriculture 1990-2012.

Figure 6: LULUCF emissions (thousand tonnes of $\mathrm{CO} 2$ equivalents) from cropland and grassland 1990-2012.

Figure 7: Ammonia emissions (thousand tonnes) in 2012

Figure 8: Ammonia emissions from agriculture 1990-2012.

Figure 9: The trade-off between quality and quantity of animal produce.

Figure 10: Different forms of land use contribute differently to food production.

Figure 11: Mechanisms of financial profitability of two agricultural systems - left: conventional agriculture, and right: sustainable agriculture.

Figure 12: Intensive animal production is partly driven by increasing demand for animal products on a global market.

Figure 13: Drivers of the demand for animal products.

Figure 14: The mechanism affecting agricultural policy.

Figure 15: A holistic picture of the drivers behind emissions from agriculture. 



\section{References}

\section{Denmark}

Baggrundsnotatet om frøgræshalm: Notat om mængden og anvendelsen af frøgræshalm. René Gislum og Birte Boelt. Institut for Agroøkologi, Aarhus Universitet. 2012.

Concito 2014. Klimagevinster ved øget proteinproduktion i Danmark. Rapport 27. January 2014. Torben Chrintz.

DCA27: Effekter af tiltag til reduktion af landbrugets udledninger af drivhusgasser. DCA Rapport NR. 027. August 2013. Århus universitet. Jørgen E. Olesen, Uffe Jørgensen, John E. Hermansen, Søren O. Petersen, Jørgen Eriksen, Karen Søegaard, Finn P. Vinther, Lars Elsgaard, Peter Lund, Jan V. Nørgaard og Henrik B. Møller.

DCA33: Biomasseudnyttelse i Danmark - Potentielle ressourcer og bæredygtighed. DCA Rapport Nr. 033 December 2013. Århus Universitet. Uffe Jørgensen, Lars Elsgaard, Peter Sørensen, Preben Olsen, Finn P. Vinther, Erik F. Kristensen, Rasmus Ejrnæs, Bettina Nygaard, Paul Henning Krogh, Annette Bruhn, Michael Bo Rasmussen, Anders Johansen, Søren Krogh Jensen, Morten Gylling Og Mikkel Bojesen.

DCE: Virkemidler til N-reduktion - potentialer og effekter. Notat til Kvælstofudvalget fra DCE - Nationalt Center for Miljø og Energi og DCA - Nationalt Center for Fødevarer og Jordbrug, Aarhus Universitet. Andersen, H.E., Grant, R., Blicher-Mathiesen, G., Jensen, P.N., Vinther, F.P., Sørensen, P., Hansen, E.M., Thomsen, I.K., Jørgensen, U., Jacobsen, B., 2012.

DCE 2014a. Greenhouse gases. Institut for Miljøvidenskab. Aarhus Universitet. Revised01.07.2014. http://envs.au.dk/videnudveksling/luft/emissioner /greenhouse_gases/

DCE 2014b. Ammonia. Air Pollutants. Department of Environmental Science. Revised 2014.07.01. http://envs.au.dk/en/knowledge/air/emissions/air-pollutants/nh3/

DCE48: Projection of Greenhouse Gases 2011-2035. Ole-Kenneth Nielsen et al. Scientific Report from DCE - Danish Centre for Environment and Energy. No. 48, 2013. Aarhus University.

DCE101. Denmark's national inventory report 2014. Emission Inventories 1990-2012 - Submitted under the United Nations Framework Convention on Climate Change and the Kyoto Protocol. Scientific Report from DCE - Danish Centre for Environment and Energy No. 101. 2014.

Eionet 2014. Eionet. Central Data Repository. Air Emission Inventories.

Inventories for the EU Monitoring Mechanism of Community $\mathrm{CO}_{2}$ and other Greenhouse Gases. Submission March 15 2014, for years 1990-2012. http://cdr.eionet. europa.eu/dk/Air_Emission_Inventories.

Energistyrelsen 2014. Energistatistik 2012, 2. edition. 2014.

Landbrug \& Fødevarer 2013. Energistatistikken 2013. Økonomisk analyse.

1 November 2013.

HST6: http://www.statistikbanken.dk/hst6

HALM1: http://www.statistikbanken.dk/halm1 
Klima på bordet. Rapporten "Landbrug og klima" - en oversigt, 2008, Ministeriet for Fødevarer.

Landbrug og Fiskeri, online: http://fvm.dk/fileadmin/user_upload/FVM.dk /Dokumenter/Foedevarer/Indsatser/Klima/Fakta_Landbrug_klima_tabeller.pdf

Notat om økonomi i husdyrproduktionen i Danmark, 2010, Københavns Universitet, Fødevareøkonomisk Institut, Brian H. Jacobsen, Alex Dubgaard, Lars-Bo Jacobsen og Hanne Marie L. Jespersen, online: http://mst.dk/media/mst/66635/Notat husdyrproduktion_i_DK_F\%C3\%98I.pdf

Ole-Kenneth Nielsen. Personal email communication 3 March 2014.

Virkemiddelkataloget. Virkemiddelkatalog - potentialer og omkostninger for klimatiltag. Tværministeriel arbejdsgruppe. August 2013.

\section{Finland}

Arbets- och näringsministeriet. 2008. Klimat- och energistrategi på lång sikt. Statsrådets redogörelse till riksdagen den 6 november 2008. Available on the web: www.tem.fi

European Parliament and Council Directive 2001/81/EC of 23 October 2001 on national emission ceilings for certain atmospheric pollutants.

European Environmental Agency (a). National emissions reported to the UNFCCC and to the EU Greenhouse Gas Monitoring Mechanism. Data available on the web: http://www.eea.europa.eu/data-and-maps/data/national-emissions-reported-tothe-unfccc-and-to-the-eu-greenhouse-gas-monitoring-mechanism-8

European Environmental Agency (b). National emissions reported to the Convention on Long-range Transboundary Air Pollution (LRTAP Convention). Data available on the web: http://www.eea.europa.eu/data-and-maps/data/national-emissionsreported-to-the-convention-on-long-range-transboundary-air-pollution-lrtapconvention-4

Grönroos, J. m.fl. 2009. Development of the ammonia emission inventory in Finland. Revised model for agriculture. The Finnish Environment 8/2009. Finlands Miljöcentral.

Jord- och skogsbruksministeriet. Program för utveckling av landsbygden i Fastlandsfinland 2007-2013. Retrieved 17.6.2014 from: http://www.landsbygd.fi/sv/index /landsbygdsprogrammen/mal_och_verktyg.html

Jord- och skogsbruksministeriet. 2008. Lannoitevalmistesektorin tulevaisuuskatsaus vuosille 2009-2013. Työryhmämuistio 2009:1. Retrieved 22.6.2014 from:

http://www.mmm.fi/attachments/mmm/julkaisut/tyoryhmamuistiot/2009/5DZn i0S8G/trm1_2009.pdf

Jord- och skogsbruksministeriet. 2010. Rehustrategiatyöryhmän raportti. Työryhmämuistio 2010:9. Retrieved 22.6.2014 from: http://www.mmm.fi/attachments /mmm/julkaisut/tyoryhmamuistiot/2010/5u8Zwr8Vm/Rehustrategiatyoryhman_ raportti_final_NEW_220910.pdf

Niskanen, O. \& Lehtonen, E. 2014. Maatilojen tilusrakenne ja pellonraivaus Suomessa 2000-luvulla.

Julkaisussa: Maataloustieteen Päivät 2014 [webbpublikation]. Suomen Maataloustieteellisen Seuran julkaisuja no 30. Red. Mikko Hakojärvi ja Nina Schulman.

Retrieved [11.6.2014]. Published 9.1.2014. Available on the web: www.smts.fi (Maatilojen tilusrakenne ja pellonraivaus Suomessa 2000-luvulla).

Niemi, J. m.fl. 2013. Suomen ruokaturvan ja elintarvikehuollon nykytila ja tulevaisuuden näkymät. MTT Raportti 80. MTT. 
Ollikainen, M. m.fl. 2014. Ympäristöllisesti ja sosiaalisesti kestävä ilmastopolitiikka maataloudessa.

Suomen ilmastopaneeli. Raportti 1/2014.

Regina, K. m.fl. 2014. Maatalouden kasvihuonekaasupäästöt ja niiden vähentäminen. MTT Raportti 127. MTT Jokioinen.

Statistikcentralen. 2012. Statistisk årsbok för Finland 2012.

Statistikcentralen. 2013a. Ympäristötilasto. Vuosikirja 2013.

Statistikcentralen. 2013b. Suomen kasvihuonekaasupäästöt 1990-2011.

Tike. 2003. Lantbruksstatistisk årsbok 2003.

Tike. 2012. Lantbruksstatistisk årsbok 2012.

Tike. 2013. Konsumtion av livsmedel per person 1990-2012. Table retrieved 6.6.2014 from: http://www.maataloustilastot.fi/sv/tilasto/144

Tike. 2014a. Peltokasvitilastot. Tilastovakka-julkaisusarja 2/2014. Published 29.4.2014. Retrieved 17.6.2014 from: http://www.maataloustilastot.fi/e-lehtipeltokasvit-2013/index.html

Tike. 2014b. Utnyttjad jordbruksareal 2013. Uppdaterad 29.4.2014. Table retrieved 29.10.2013 from: http://www.maataloustilastot.fi/sv/utnyttjad-jordbruksareal

Tike(a). Antal fjäderfän i hela landet, 1990-2013. Table retrieved 17.6.2014 from: http://www.maataloustilastot.fi/sv/antalet-husdjur

Tike(b). Antal jordbruks- och trädgårdsföretag områdesvis enligt produktionsinriktning 2013 och 2010-2013. Table retrieved 17.6.2014 from: http://www.maataloustilastot.fi /sv/lantbrukets_struktur

Tike(c). Antal nötkreatur i hela landet åren 1990-2013. Table retrieved 29.10.2013 from: http://www.maataloustilastot.fi/sv/antalet-husdjur

Tike(d). Antal svin i hela landet åren 1990-2013. Table retrieved 17.6.2014 from: http://www.maataloustilastot.fi/sv/antalet-husdjur

Tike(e). Gårdarnas jorddisponering områdesvis år 2012 och åren 2000-2012. Table retrieved 29.10.2013 from: http://www.maataloustilastot.fi/sv/lantbrukets_struktur

Tike(f). Jordbruks- och trädgårdsföretagens utnyttjade jordbruksareal i medeltal områdesvis år 2013. Table retrieved 19.6.2014 from: http://www.maataloustilastot.fi /sv/lantbrukets_struktur

Tike(g). Nötköttproduktion enligt ELY-central åren 1997-2013 (milj.kg). Table retrieved 17.6.2014 from: http://www.maataloustilastot.fi/sv/kottproduktionomradesvis

Tike(h). Svinköttproduktion enligt ELY-central åren 1997-2013 (milj.kg). Table retrieved 17.6.2014 from: http://www.maataloustilastot.fi/sv/kottproduktionomradesvis

Yara Suomi Oy. Data retrieved 06/23/2014 from website: http://www.yara.fi/tietoayarasta/kestava-kehitys/hiilijalanjalki/hiilijalanjalkitakuu/

\section{Norway}

Budsjettnemnda for jordbruket, 2013, Resultatkontroll for gjennomføringen av landbrukspolitikken.

Climate and Pollution Agency, 2013, National Inventory Report.

European Environmental Agency(a). National emissions reported to the UNFCCC and to the EU Greenhouse Gas Monitoring Mechanism. Data available on the web: http://www.eea.europa.eu/data-and-maps/data/national-emissions-reported-tothe-unfccc-and-to-the-eu-greenhouse-gas-monitoring-mechanism-8 
European Environmental Agency(b). National emissions reported to the Convention on Long-range Transboundary Air Pollution (LRTAP Convention). Data available on the web: http://www.eea.europa.eu/data-and-maps/data/national-emissionsreported-to-the-convention-on-long-range-transboundary-air-pollution-lrtapconvention-8

Grønlund, Arne and Harstad, Odd Magne, Klimagasser fra jordbruket. Tema nr. 18 april 2014 - (Norges miljø- og biovitenskaplige univeersitet).

Kvalevåg, Maria Malene Miljødirektoratet, personal communication 5 May 2014.

Landbruks- og matdepartementet, 2009, Klimautfordringene - landbruket en del av løsningen.

https://www.regjeringen.no/contentassets/1e463879f8fd48ca8acc2e6b4bceac52/ no/pdfs/stm200820090039000dddpdfs.pdf

Miljødirektoratet, Ammoniakk (NH3) “http://www.miljostatus.no/Tema /Luftforurensning/Sur-nedbor/Ammoniakk-NH3/" 2015-04-24

Sørheim, Kristin - Bioforsk økologisk, Tingvoll, oral communication in March 2015.

Article on carbon reductions in agricultural sector: "Hvordan redusere klimagassutslipp fra jordbruket?" available at: http://www.bioforsk.no/ikbViewer/page/forside /nyhet?p_document_id=64714

\section{Sweden}

European Environmental Agency(a). National emissions reported to the UNFCCC and to the EU Greenhouse Gas Monitoring Mechanism. Data available on the web: http://www.eea.europa.eu/data-and-maps/data/national-emissions-reported-tothe-unfccc-and-to-the-eu-greenhouse-gas-monitoring-mechanism-8

European Environmental Agency(b). National emissions reported to the Convention on Long-range Transboundary Air Pollution (LRTAP Convention). Data available on the web: http://www.eea.europa.eu/data-and-maps/data/national-emissionsreported-to-the-convention-on-long-range-transboundary-air-pollution-lrtapconvention-8

Greppa Näringen, 2014. Projektet Greppa Näringen (http://www.greppa.nu/omgreppa/om-projektet.html) Retrieved 2014-07-07.

Kimatmärkning, 2014 (http://www.klimatmarkningen.se/). Retrieved 2014-07-04.

Miljöaktuellt, 2013. Livsmedelsverket uppdaterar miljösmarta kostråd (http://miljoaktuellt.idg.se/2.1845/1.534593/livsmedelsverket-uppdaterarmiljosmarta-kostrad) Published 2013-11-19, Retrieved 2014-07-07.

The National Food Agency 2013, Miljösmarta matval. (http://www.slv.se/sv /grupp1/Mat-och-miljo/Miljosmarta-matval/). Published 2013-11-19, Retrieved 2014-07-07.

The Swedish Board of Agriculture 2012 (a). Ett klimatvänligtjordbruk 2050. Rapport 2012:35. Available on the web: http://www2.jordbruksverket.se/webdav/files /SJV/trycksaker/Pdf_rapporter/ra12_35.pdf

The Swedish Board of Agriculture 2012 (b). Sveriges utrikeshandel med jordbruksvaror och livsmedel 2009-2011. Rapport 2012:32 Available on the web: http://www2.jordbruksverket.se/webdav/files/SJV/trycksaker/Pdf_rapporter/ra 12_32.pdf

The Swedish Board of Agriculture 2013. Presentation "SMED-scenarier" av Magnus Bång dated 2013-06-19. 
The Swedish Board of Agriculture 2013 (b). Sveriges utrikeshandel med jordbruksvaror och livsmedel 2010-2012. Rapport 2013:27 Available on the web: http://www2.jordbruksverket.se/webdav/files/SJV/trycksaker/Pdf_rapporter/ra 13_27.pdf

The Swedish Board of Agriculture 2014a Miljöersättningar. (http://www. jordbruksverket.se/amnesomraden/stod/jordbrukarstod/miljoersattningar. 4.7850716f11cd786b52d8000485.html) Retrieved 2014-07-01.

The Swedish Board of Agriculture. 2014b. Miljöersättningar 2015.

(http://www.jordbruksverket.se/amnesomraden/stod/jordbrukarstod/jordbruka rstod2015/miljoersattningar2015.4.1b8a384c144437186eae6d7.html) Retrieved 2014-07-01.

The Swedish Board of Agriculture, 2014c. Växtnäring. (http://www.jordbruksverket.se /amnesomraden/odling/vaxtnaring.4.373db8e013d4008b3a18000442.html) Retrieved 2014-07-01.

The Swedish Board of Agriculture and Statistics Sweden. 2013. Jordbruksstatistisk årsbok 2013. Available on the web: www.jordbruksverket.se

The Swedish Board of Agriculture and Statistics Sweden. 2014. Jordbruksstatistisk årsbok 2014. Available on the web: www.jordbruksverket.se

The Swedish Environmental Protection Agency, 2014, Ingen övergödning - ammoniakutsläpp (http://www.miljomal.se/Miljomalen/Alla-indikatorer/Indikatorsida /?iid=5\&pl=1) Retrieved 2014-07-04.

Velthof G.L., J.P. Lesschen, J. Webb, S. Pietrzak, Z. Miatkowski, J. Kros, M. Pinto, and O. Oenema. 2009. The impact of the Nitrates Directive on gaseous N emissions. Available on the web: http://ec.europa.eu/environment/water/water-nitrates/pdf /Final_report_impact_Nitrates_Directive_def.pdf 



\section{Sammanfattning}

Denna rapport utgör en huvudkomponent under projektet "Pathways to a Nordic food system that contributes to reduced emissions of greenhouse gases and air pollutants" - vilket är ett projekt som finansieras av Nordiska ministerrådet och påbörjades 2013. Denna rapport är ett resultat av de nordiska lägesrapporter (se bilagorna) samt de workshops som anordnades under 2013 och 2014.

Rapporten har två huvudsakliga målsättningar. Först skall den kartlägga data och information gällande den nordiska jordbrukssektorn, dess struktur och utsläpp av växthusgaser och ammoniak men även att kortfattat beskriva andra väsentliga faktorer, t.ex. det rättsliga/ administrativa ramverket, intressekonflikter och subventionssystem. En andra målsättning är att beskriva vägar mot ett mer hållbart nordiskt jordbruk som når de målsättningar som satts för klimat och luftföroreningar.

Rapporten visar att fastän norden är en relativt homogen region från ett kulturellt, socialt och ekonomiskt perspektiv så finns det åtskilliga geologiska, topografiska och klimatmässiga skillnader som begränsar jordbruksaktiviteterna. Dessutom är förutsättningarna olika för småoch storskaliga gårdar. En övergripande gemensam faktor för det nordiska jordbruket är att en relativt liten del av landytan (3-8 \%) används för jordbruksproduktion med undantag för Danmark som nyttjar mer än hälften av landytan för jordbruk.

En annan gemensam trend är minskningen av antalet mjölkkor men ökad mjölkproduktion per ko. Även antalet jordbruksgårdar har minskat generellt vilket i flera fall föranlett en ökad köttimport särskilt av nötkött. Det finns stor spännvidd och variation mellan länderna gällande produktion av grödor och kött samt andra jordbruksprodukter. En gemensam trend är minskad nötdjursproduktion men ökad fjäderfä- och grisproduktion.

Jordbruket skall också ses från ett demografiskt och arbetsmarknadsperspektiv. Det finns få jobb i jordbrukssektorn, uppskattad till 2-3 \% av den totala arbetskraften. De flesta som arbetar inom jordbruket är 50 år eller mer. De nordiska länderna strävar efter att göra jordbruksyrket mer attraktivt, t.ex. genom ekonomiska åtgärdspaket som främst riktar sig till den yngre generationen 
Gällande utsläpp från jordbruket, motsvarar metan och lustgas utsläppen 8-9 i Norge och Finland med högre nivåer i Sverige och Danmark (13 respektive $19 \%$ ). Dessa utsläppsnivåer blir väsentligt högre när man räknar in utsläpp från marknyttjande och energiförbrukning, i dessa fall kan nivåerna ungefär 27 \% i Danmark. Dessutom måste man räkna in utsläpp kopplade till importerade jordbruksprodukter såsom djurfoder och gödsel.

Lustgas utsläpp från jordbruket är störst i Danmark med 90 \% och lägst i Finland. Alla länder utom Norge har sett en minskning i utsläppen, främst på grund av en minskad användning av kvävegödsel. Metanutsläppen har legat på en konstant nivå de senaste 20 åren.

Utsläppen från ammoniak är ett betydande problem för jordbruket och det nordiska utsläppen ligger runt $90 \%$. Naturgödsel utgör den största utsläppskällan på mellan $80-90 \%$ och dessa utsläpp påverkas främst genom aktiva (policy) åtgärder.

Samtliga nordiska länder har någon form av ramverk och kontrollmekanismer gällande spridandet, lagrandet och användandet av gödsel med de strängaste reglerna i Danmark. I flera fall har subventionssystem och andra stödprogram införts men dessa verkar inte alltid i förmån till ett paradigmskifte mot mera hållbara jordbruks- och livsmedelssystem. Det nuvarande ramverket främjar t.ex. främst större, intensivare jordbruk. Traditionellt och historiskt sätt traditionellt sätt så har ju en stor jordbruksproduktion varit av en hög jordbrukspolitisk prioritet.

Det är tydligt att jordbruket idag inte täcker jordbrukets externa miljö- och hälsokostnader. Marknadsekonomiska styrmedel såsom skatter har begränsad användning och effekt särskilt då det kan vara svårt att uppskatta de precisa utsläppen från jordbruk. Globaliseringen av jordbruket och konkurrensvillkoren är en annan orsak till en begränsad användning av ekonomiska styrmedel.

Det föreligger en rad intressekonflikter som direkt eller indirekt motverkar ett jordbruk med minskad klimat- och luftföroreningspåverkan. Några av dessa intressekonflikter finns inom områden såsom djurhållning, mångfald/biodiversitet, landskap i kulturell bemärkelse, böndernas ekonomiska realitet, efterfrågan av billig mat, handelsavtalsregleringar, globaliseringen av matproduktionen, markanvändningsintressen och otillräcklig transparens.

Dessa intressekonflikter leder ofta till oönskade situationer där vissa (ekonomiska) intressen gynnas. Detta måste ta i beaktande i utformningen och innan införandet av diverse policy, tekniska, administrativa eller fiskala åtgärder. 
Det finns många kopplingar och beroendefaktorer mellan olika aspekter och faktorer som påverkar jordbruks- och livsmedelssystem. Detta visualiseras i form av så kallade "casual loop diagrams" i kapitel 5. Genom detta integrerande helhetsperspektiv är det möjligt att belysa vikten av allmänhetens miljö och sociala medvetenhet. Om det politiska systemet hade fullständig transparens så är sannolikheten att ökad miljömedventenhet hos allmänheten automatiskt leder till internalisering av miljökostnaderna för ett intensifierat jordbruk och en revidering av ett bidragssystem som bygger på låga jordbrukspriser samt en livsmedelskonsumtion som hade mindre miljöpåverkan (t.ex minskad köttkonsumtion till fördel för grönsaker). Då systemet inte är perfekt behövs fler riktade åtgärder och informations- och medvetenhetsstärkande för att uppnå denna internalisering av miljökostnader och ett paradigm skifte i hur vi ser på jordbruksproduktion och konsumtionsmönster.

För att illustrera variationen i olika typer av åtgärder som kan påverka miljö- och klimatpåverkan från jordbruket har vi tagit fram en enkel åtgärdslista som är uppdelade enligt kategori, d.v.s. gödselhantering, energieffektivisering, djurfoder, markanvändning, energiproduktion. Vad vi kan se från åtgärdslistan är att de åtgärder som är vanligast är reglering av gödselhanteringen, täckning av uppslammningsbehållare, täckning av gödselhögar, optimera gödsling av fält, minska gödselområdet samt ökad användning av gröngödsel på åkermark.

Åtgärder som mer sparsamt används är energieffektivisering såsom energisnåla ventilationssystem, minska energiförbrukning under mjölkning och ersätta fossila bränslen såsom diesel med förnybara bränslen. Inte heller energiproduktion från jordbruket är särskilt vanligt med input massa såsom biomassa, gödsel och halm.

Gällande mer mjukare åtgärder som kan påverka livsmedelssystem och konsumtionsvanor positivt i form av minskade växthusgaser är det vanligt att försöka motverka matsvinn. Till mycket mindre utsträckning tas åtgärder för att minska antalet boskap och produktionen av kött, mjölk och ägg.

\section{Rapportens huvudsakliga slutledningar}

- Det finns ett stort värde av att utbyta erfarenheter och kunskap inom området. Tillämpad verksamhet och policy kan överföras till andra länder och en ökad förståelse av utvecklingen och perspektiven av nordiskt jordbruk kan ge nya lösningar för att minska utsläppen från jordbruket samt att jordbruket delvis utgör en kolsänka. 
- Vi behöver större insikt i de intressekonflikter som påverkar de åtgärder som kan tas och ibland ger oönskade resultat.

- Utsläppsbegränsningar och de åtgärdspaket och verktyg som används för att påverka utsläppen är även avhängiga den lokala kontexten, klimatet, konsumtionsmönster, policy ramverket och import- och exportbalansen för jordbruksprodukter.

- Styrmedel och ökade incitament är nödvändigt för att genomdriva utsläppsminskningar på gårdsnivå. T.ex. småbönder har svårt att täcka de extra kostnader som kommer från tekniska åtgärder och åtgärdspaket bör därför också innehålla incitament för småskaligt jordbruk.

- Det finns behov av fler och mer djupgående dietrekommendationer som inte bara baseras på hälsoaspekter utan även utsläpps- och klimatpåverkan.

- Fler åtgärder och ökad medvetenhet behövs för att internalisera miljökostnaderna som kan leda till ett paradigmskifte i jordbruksproduktionen, konsumtionsmönster och livsmedelssystem.

\section{Preliminära rekommendationer}

Alla länder måste ha ett effektivt regelverk för att begränsa jordbrukets luftföroreningar och klimatpåverkan och detta ramverk måste bl.a. reglera gödselhantering och bruket av organiska marker för jordbruksändamål.

Utveckla åtgärdslistan i kapitel 6 för att utreda hur man kan öka dess användning såväl på övergripande politisk såväl som på gårdsnivå. Särskilt intressant är att belysa åtgärder som har stor potential, t.ex. energieffektivisering samt åtgärder som påverkar produktions- och konsumtionsmönster.

Förespråka hållbart jordbruk som yrkeskategori särskilt i den yngre generationen och utveckla nya incitament, t.ex. arbetsmarknadsåtgärder och stödsystem för att göra jordbruket mer lockande.

Styra mot ett paradigm skifte med nytt förhållningssätt hur vi ser på jordbruksproduktion, livsmedelssystem och konsumtion som bättre balanserar olika ekonomiska och andra samhällsintressen, och hur vi säkerställer att jordbrukets negativa miljöeffekter begränsas så långt som möjligt. 
Ta sikte mot ett integrerat förhållningssätt till livsmedel och jordbrukspolitiken som även beaktar de globala perspektiven som även innefattar målsättning att minska fattigdom och svält och den ojämna mattillgången mellan länder. Det hållbara nordiska jordbruket skall stödja FAO rekommendationer och andra relevanta internationella regelverk och rekommendationer och bidra till att lösa de globala utmaningarna. 



\section{Annex 1: National Report: Agriculture in Denmark}

Project: "Pathways to a Nordic food system that contributes to reduced emissions of greenhouse gases and air pollutants".

\section{Introduction}

This national report constitutes an output under the project "Pathways to a Nordic food system that contributes to reduced emissions of greenhouse gases and air pollutants". This project is financed by the Nordic Minister Council and commenced in 2013. This report constitutes an annex to the comprehensive Nordic report: "Nordic agriculture air and climate - Baseline and system analysis report" and much of the data for Denmark was extracted from this national report. The national report mainly focuses on the national agricultural structures, land area use, agricultural production and current and projected greenhouse gas and ammonia emissions.

The main authors of this report are Bente Hessellund Andersen (Miljøbevægelsen NOAH and Frie Bønder - Levende land) and Jacob Sørensen Miljøbevægelsen NOAH. Kajsa Lindqvist and Miriam MárkusJohansson have given valuable comments and contributed to the final lay-out of the Danish report.

\section{A brief description of the agricultural sector over a 30 year-period}

\section{Area}

In 2012 Danish agriculture occupied 26,669 $\mathrm{km}^{2}$ (which translates into approx. 2.7 million hectares). This represents $62 \%$ of Denmark's total area of $43,094 \mathrm{~km}^{2}$. Since 1982 , there has been a decline in the cultivated area: 
- 1982: approximately 2,900,000 ha.

- 1990: 2,788,000 ha.

- 2012: 2,669,000 ha.

Hence, there has been a decline in the cultivated area of approximately 8\% during the last 30 years (4\% between 1990 and 2012).

\section{Structural development}

An overall trend in Danish agriculture is that there are fewer and fewer, but increasingly larger farms. Within the past 30 years, the number of farms has more than halved from just over 100,000 farms in 1982 to about 40,600 in 2012 , of which only approximately $30 \%$ are full-time farms. The reduction was most noticeable among full-time farms. This development occurred in parallel with changes in farming methods towards increased mechanization and specialization promoted and justified (by the agroindustrial complex) by demand for high productivity in order to maintain competitiveness in a global market.

The average size of a Danish farm has more than doubled since 1982, from just below 30 hectares to about 66 ha in 2012. In the meantime specialization in livestock production has led to fewer but larger livestock herds. The trend is particularly noticeable for swine holdings where the average herd size has increased from 169 pigs per year and farm in 1982 to almost 3,000 in 2012. Cattle numbers have almost halved over the same period, whereas the average herd size has more than doubled, from 53 to 127 per holding.

\section{Agricultural production}

In 2012, the annual total in crop production amounts to about 170 million crop units (equivalent to the feeding value of 17 million tonnes grain), 16 over half of which are grain crops. Approximately $80 \%$ of plant production is used as feed for livestock, mainly pigs and cattle. $9 \%$ of the land is used to produce cereals, potatoes, sugar beet and vegetables for

\footnotetext{
16 One feeding value unit is equivalent to the feeding value of $1 \mathrm{~kg}$ of barley, wheat or rye; $1.2 \mathrm{~kg}$ oats; $1 \mathrm{~kg}$ dry matter from potatoes, beets, carrots or clover; $1.3 \mathrm{~kg}$ dry matter from beet tops; $4 \mathrm{~kg}$ of straw from wheat, barley or oat or $4.5 \mathrm{~kg}$ straw from rye. 100 feeding value units correspond to one crop unit (source: www.den storedanske.dk).
} 
human consumption. The remaining $10 \%$ is used for industrial potatoes, rapeseed for biodiesel, grass seed, Christmas trees, or fallow. Approximately $7 \%$ of the area is organic.

Milk production has decreased slightly since the introduction of the milk quota in 1984 and is currently at a total of approximately 4.5 million tonnes. The total number of dairy cows, however, has been almost halved over the period, while yield per cow has almost doubled. In 2012, dairy cows gave on average 9,019 kg of milk annually.

Pig production increased in number from approx. 9 million in 1990 to 12 million in 2012. This reflects the number of pigs at any time during the year. However, approx. 20 million pigs are slaughtered in Denmark per year and on a daily basis approx. 4,500 tonnes of pig meat is produced. In recent years there has been a change in the composition of the pig population, since more piglets are exported to feed outside Denmark. Between 2008 and 2012 the export of piglets has risen from 5.3 million to 9.2 million on a yearly basis, and the number of pig slaughtered in Denmark has decreased. The relative proportion of sows has therefore increased. (Jordbruget i Danmark, Danmarks Statistik (2014); Notat om økonomi i husdyrproduktionen i Danmark (2010)).

\begin{tabular}{lrrrr} 
Table 1: Number of animals in Danish agriculture \\
\multicolumn{1}{c}{$\mathbf{1 9 8 9}$} & $\mathbf{1 9 9 9}$ & $\mathbf{2 0 1 0}$ & $\mathbf{2 0 1 2}$ \\
Cattle & & & \\
Pigs & $2,221,485$ & $1,887,057$ & $1,571,050$ & $1,606,826$ \\
Sheep & $9,189,981$ & $11,626,043$ & $13,173,060$ & $12,330,879$ \\
Goats & 144,168 & 142,880 & 159,626 & 153,691 \\
Horses & n.a. & n.a. & 13,005 & 9,354 \\
Poultry & 35,446 & 40,485 & 59,735 & 68,467 \\
Fur animals & $17,194,203$ & $21,010,135$ & $18,731,331$ & $18,990,746$ \\
\hline
\end{tabular}

The distribution of different soil types and production forms is reflected in the livestock density in different parts of the country, which is highest in Northern and Western Jutland and least on Zealand. Zealand is characterized by a relatively larger share of crop production in general; however roughage production is the highest in Jutland.

The Danish farming emissions are closely linked to livestock - directly in the form of emissions from manure management and ruminant digestion and indirectly in terms of the emissions associated with feed production in Denmark and abroad. 


\section{Imports/exports}

Denmark has the possibility to be self-sufficient with food and drinks and still be an exporter of agricultural products. However, the picture is not very clear if we look at how many people Denmark is actually sustaining or how many people the country could sustain.

In economic terms, Denmark has a positive balance in the figures related to agriculture. In 2012, the value of the total imports of landbased crops and fish was DKK 528,924 million while the export was DKK 614,675 million.

A more detailed inventory shows that imports of food products and live animals had the value of DKK 58,092 million and exports in the same category had the value of DKK 101,160 million; imports of beverages and tobacco had the value of DKK 6,662 million and the corresponding exports had the value of DKK 6,310 million; imports of animal and vegetable oils and waxes had the value of DKK 4,919 million and the corresponding exports had the value of DKK 3,933. Hence, there is quite a large surplus in the import/export balance related to food products and live animals and small deficits in the balances for beverages and tobacco and for animal and vegetable oils and waxes. The surplus in the food products and live animals is largely associated with the exports of relatively expensive meat and dairy products, which are very dependent on relatively cheap imported feed, of which Denmark imports around two million tonnes every year.

We have not been able to find balances that show the calorific surplus or deficit in the import-export calculations, nor have we found resent calculation showing the import/export balances regarding landuse related to imported and exported products. However, both of these comparisons would give a more balanced picture regarding the degree of self-sufficiency if they were included in the Danish agricultural sector's accounts. These balances should be integrated in our future work on scenarios.

\section{Employment, demography and consumption}

Out of about 40,600 farms (in 2012), approx. 12,000 were full-time farms (where working hours are over 1,665 hours per year) and about 28,000 were part-time farms. Full-time farms accounted thus for approx. $30 \%$ of the farms.

In $2012,69,643$ people were employed in agriculture, forestry and fishery, whereas the total labour force was approx. 2,623,000 people. This means that these sectors employ less than $3 \%$ of the total labour 
force in Denmark. $43 \%$ of those employed in agriculture, forestry and fishing are $50+$ years and $15 \%$ are 67 years or older.

If one considers merely the group of self-employed within these sectors, $69 \%$ are $50+$ years and $28 \%$ are $67+$ years. This trend of increased age amongst the self-employed within these sectors partly reflects the fact that the land in Denmark has become so expensive and farms have become so large that younger farmers find it very difficult to get established. The Danish Government try to encourage young farmers (up to 40 years) to establish themselves on their own farm by extra financial support.

Due to the trend of increased export of piglets and a decreased number of pigs growing up in the country for slaughtering, the number of Danish Crown pig slaughterhouses within Denmark has fallen from 54 in 1974 to 20 in 1980. Today there are two left. In addition, there are seven other slaughterhouses that slaughter more than 10,000 pigs per year. Danish Crown has dismissed 7,100 employees during the last 10 years. In 2012, the company had 8,000 employees in Denmark and 15,000 abroad. Hence, the trend of exporting piglets goes hand in hand with Danish Crown moving more and more production and jobs overseas.

Furthermore, this development occurred in parallel with declining world prices for agricultural products and thereby decreasing income, which has resulted in a generally poor economy in Danish agriculture, which is largely depending on exports. Although the world market prices are determining for the economy in Danish agriculture, the farmers' income is also affected by the home market and, thus, on how much the Danes are spending on food. However, "food" takes up relatively ever less in the Danes' budget. In 1985, Danish consumption of food constituted around $22 \%$ of their total spending. 10 years later it was approximately 18\%; 20 years later it had fallen to about 14\%; and today it is down to just below $10 \%$.

\section{Agricultural emissions of greenhouse gases and ammonia - over the last 20 years}

\section{Domestic emissions of greenhouse gases}

In 2012, Denmark's total emissions (excl. LULUCF) were 51.6 million tonnes of $\mathrm{CO}_{2} \mathrm{e}$. When including LULUCF, the emissions were 50.8 million tonnes of $\mathrm{CO}_{2} \mathrm{e}$ (Energistyrelsen (2014); Eionet (2014)). 
In 1990, total emissions (excl. LULUCF) were 68.7 million tonnes $\mathrm{CO}_{2} \mathrm{e}$. When including LULUCF, the emissions were then 73.9 million tonnes $\mathrm{CO}_{2} \mathrm{e}$.

The total Danish emissions (excl. LULUCF) have thus fallen approx. 25\% from 1990 to 2012, and approx. 31\% when LULUCF is included (see Figure 1).

Figure 1: Greenhouse gas emissions in $\mathrm{CO}_{2}$-equivalents distributed on main sectors and for the time-series 1990-2012 (million tonnes $\mathrm{CO}_{2}$ equivalents). DCE 2014a

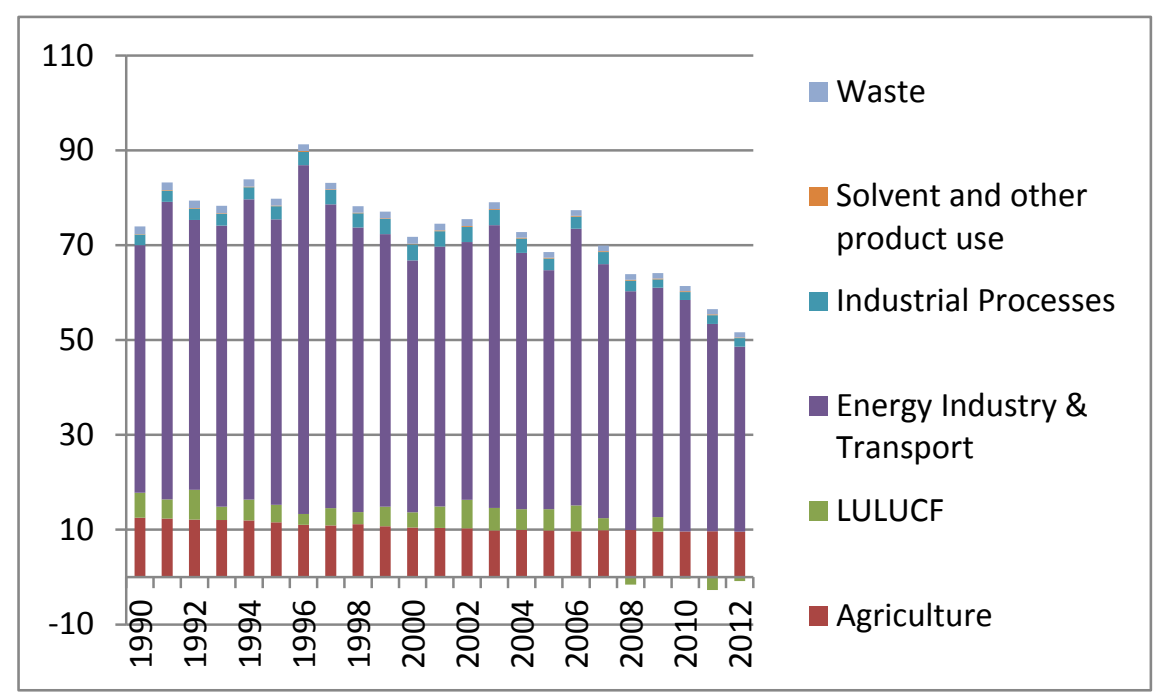

After "Energy Industry and Transport", the agricultural sector is the sector with the highest climate impact.

The division into sectors in Figure 1 (which is used when Denmark reports its emissions to the UNFCCC) implies that agricultural consumption of energy for e.g. transport and heating belongs to the sector "Energy Industry and Transport". The agriculture-related share of LULUCF is listed within the LULUCF sector. It is only methane and nitrous oxide, which is listed under "Agriculture". When talking about agriculture's share of the emission of greenhouse gases, contributions related to energy consumption and LULUCF is therefore often neglected.

From 1990 to 2012, emissions from agriculture (from nitrous oxide and methane) fell from about 12.5 million tonnes $\mathrm{CO}_{2} \mathrm{e}$ to about 9.6 million tonnes $\mathrm{CO}_{2} \mathrm{e}$, which is a decrease of approx. $23 \%$.

In 2012, agriculture thus represented approximately $18 \%$ of Denmark's total emissions according to the official calculations (that is excl. emissions from LULUCF and energy consumption), while the proportion 
is approx. $32 \%$ when both LULUCF and energy consumption are included (see calculation in section 3.1.3.-3.1.4.).

Finally, one can then subtract emissions saved related to the production of bioenergy substituting fossil fuels amounting to 2.4 million tonnes $\mathrm{CO}_{2} \mathrm{e}$ (as demonstrated in section 3.1.6.), when emissions related to ILUC is not included).

A calculation to summarize the emissions from agriculture can be stated as follows: $\mathrm{N}_{2} \mathrm{O}+\mathrm{CH}_{4}+\mathrm{LULUCF}+\mathrm{CO}_{2}$ (from energy consumption) - $\mathrm{CO}_{2}$ (from saved energy consumption) (all in million tonnes $\mathrm{CO}_{2} \mathrm{e}$ ) = $5.4+4.2+3.4+3.5-2.4=14.1$ million tonnes $\mathrm{CO}_{2} \mathrm{e}$. A fairly accurate estimation of agriculture's share of Denmark's total emissions domestically can thus be summarized to approx. $28 \%$.

\section{Nitrous oxide, $\mathrm{N}_{2} \mathrm{O}$}

Agriculture is the main source of nitrous oxide emissions (see Figure 2). Nitrous oxide is produced when microorganisms break down and convert various nitrogen-containing compounds. The amount of nitrogen in the soil increases when adding manure, mineral fertilizers, or if growing nitrogen-fixing plants. This increases the risk of the formation of nitrous oxide. Soils with a high content of nitrogen, especially humus-rich soils, can release some nitrous oxide, whether additional nitrogen fertilizer is applied or not. Nitrous oxide is also formed and emitted in relation to the handling and application of manure.

Nitrous oxide emissions from agriculture were 17.4 Gg in 2012 (DCE 2014a), which represents approx. $90 \%$ of the total nitrous oxide emissions (see figure 2). This is equivalent to 5.4 million $\mathrm{CO}_{2} \mathrm{e}$, which corresponds to approx. 11\% of Denmark's total emissions of greenhouse gases (the GWP factor of nitrous oxide is set to 310).

The largest share of nitrous oxide emissions comes from agricultural land. It is especially applied nitrogen from fertilizers and manure and the associated nitrogen leaching that has given and still gives rise to the greatest emissions (DCE48). 
Figure 2: Nitrous oxide emissions in Denmark 1990-2012 in 1,000 tonnes. (Danish production of nitric acid stopped in 2004 and the emissions from industrial processes is therefore not occurring from 2005 onwards). DCE 2014a

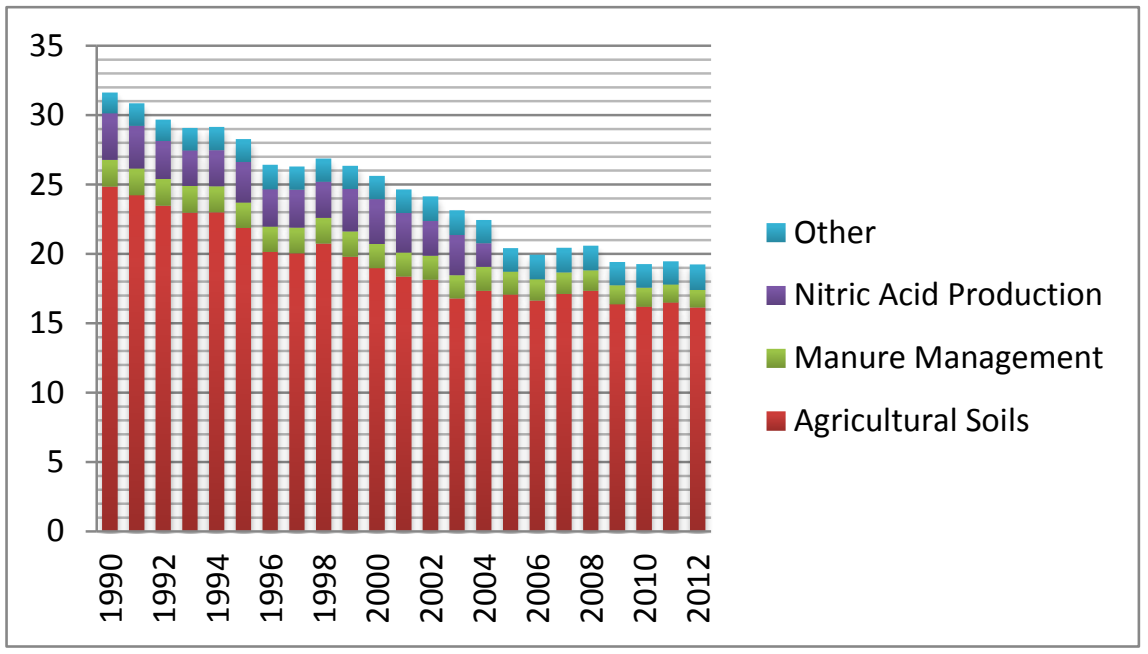

Between 1990 and 2003 there was a steady reduction in nitrous oxide emissions from agriculture (in total 30\%), but since 2003 emissions have remained at approximately the same level (see figure 2). The reduction can particularly be related to the lowering of nitrogen standards and improved utilization of the nitrogen in manure, which has resulted in reduced need for chemical fertilizers. Both of these changes are the result of implementation of ammonia emission reduction legislation according to the Danish action plans for the aquatic environment. A smaller proportion of the reduction is due to manure management and the use of nitrification inhibitors. Over the same period of years the agricultural area decreased with approximately 4\%, which also has also limited the use of nitrogen fertilizer (DCE48).

\section{Methane, $\mathrm{CH} 4$}

Agriculture is also the main source of methane emissions (see Figure 3). The major part of methane emissions in agriculture stems from ruminants. The gas is formed naturally during the digestion process (enteric fermentation). Methane is also formed via anaerobic decomposition of manure.

In 2012, the emissions were approx, $200 \mathrm{Gg}$ (which accounted for almost $77 \%$ of the total $\mathrm{CH}_{4}$ emissions of approx. $262 \mathrm{Gg}$ ). This corresponds to 4.2 million tonnes of $\mathrm{CO}_{2} \mathrm{e}$, representing almost $8 \%$ of Denmark's total emissions of greenhouse gases (the GWP factor of methane is set to 21 ). 
Methane emissions from agriculture have for more than 20 years been approximately 200,000 tons (Figure 3). The emissions from ruminants have dropped slightly, but this decrease is offset by the emissions from the handling of fertilizer that has increased due to the transition from solid manure to (more) slurry.

Figure 3: Methane emissions in Denmark for 1990-2012, measured in 1,000 tonnes. DCE $2014 a$

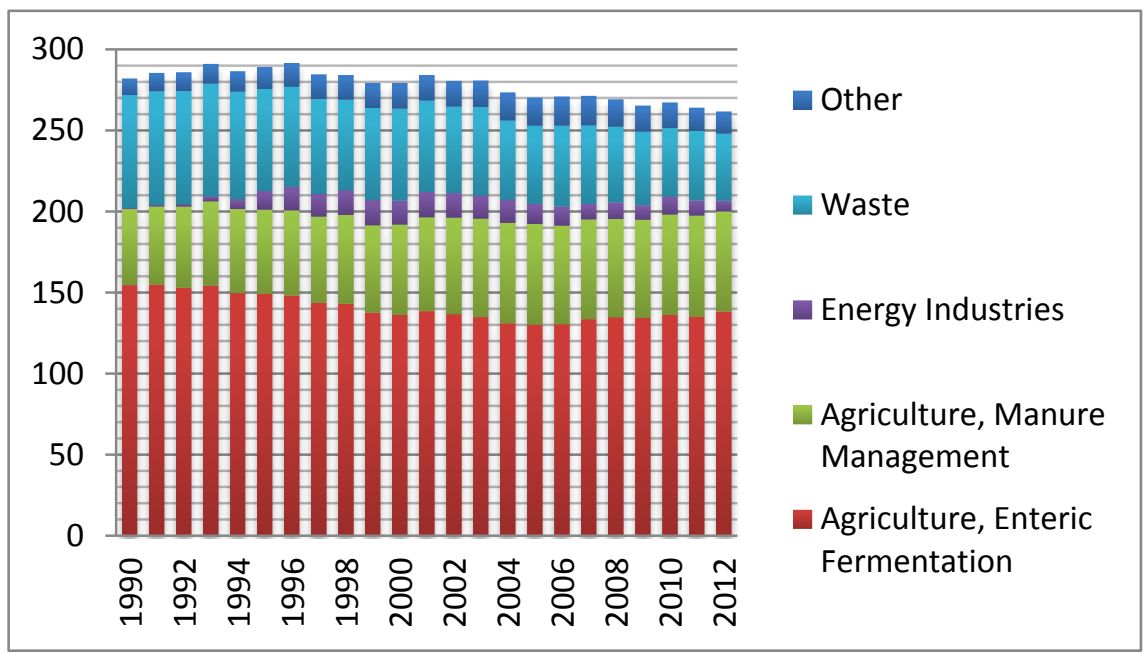

\section{LULUCF}

The LUCUCF sector covers emissions from above-ground and belowground living and dead biomass as well as carbon stored in the soil. The LULUCF sector alternates from being a net "sink" and a net source of emissions. Agriculture's share of LULUCF is defined as emissions from "Cropland" and "Grassland" (in Figure 4). In years where the LULUCF sector as a whole has been a net sink (as in e.g. 2012), it has been due to forests and forest planting. Agriculture's contribution to LULUCF has been positive throughout the years (see Figure 4).

In 2012, the LULUCF was a net "sink", with a carbon fixation representing the equivalent to approx. $2 \%$ of total greenhouse gas emissions in Denmark. In that year the forests fixed approx. 4.4 million tonnes of $\mathrm{CO}_{2} \mathrm{e}$, (equivalent to almost $9 \%$ of Denmark's total emissions) while agricultural land released approx. 3.4 million tonnes of $\mathrm{CO}_{2} \mathrm{e}$ equivalent to approx. $7 \%$ of Denmark's total emissions.

Emissions from living and dead biomass on agricultural soils changes from year to year and depend on the climatic conditions (temperature and rainfall) and crop choices in the specific year. In 2012, The loss from living and dead biomass was 0.14 million tonnes $\mathrm{CO}_{2} \mathrm{e}$. 
Since 1990 there has been a decrease in the total carbon storage in agricultural soils, although it has been prohibited (with some exceptions) to burn straw in the fields since 1990. At the same time, there has been a decrease in the area with organic soils with more than $12 \%$ content of organic carbon. Since 1975, this area has dropped from more than 70,000 ha to below 42,000 ha in 2010 . The area with a content of $6-12 \%$ organic carbon in the soil was in same time period reduced from more than 40,000 ha to 30,000 ha. The reason for these changes is the intensive cultivation, since much carbon is lost when the land is drained and ploughed to the extent practiced in Denmark. Thus, in 2012, about 1.35 million $\mathrm{CO}_{2} \mathrm{e}$ was lost from the mineral soils and about 1.87 million tonnes of $\mathrm{CO}_{2} \mathrm{e}$ was lost from the organic soils.

Figure 4: LULUCF in $\mathrm{CO}_{2}$-equivalents distributed on main land-uses and timeseries (million tonnes $\mathrm{CO}_{2}$ equivalents). Eionet 2014

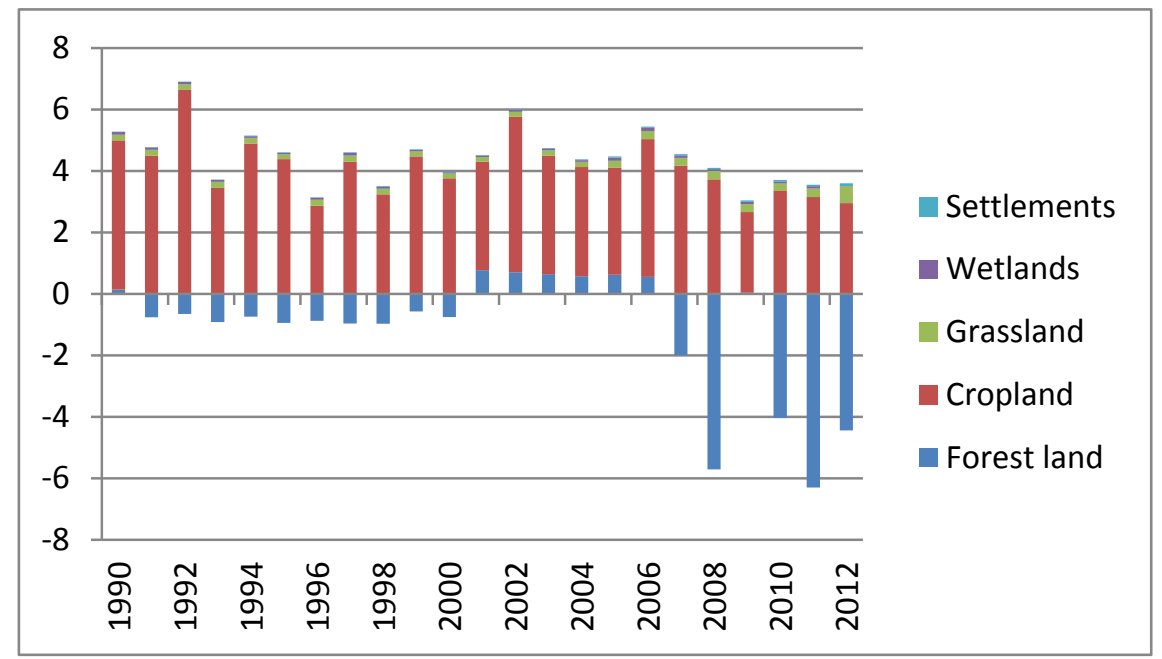




\section{Emissions from energy consumption}

In addition to the above stated agricultural emissions, emissions from energy consumption in both building and machinery should be included.

\begin{tabular}{|c|c|c|c|c|c|c|c|c|c|}
\hline & Electricity & Diesel oil & $\begin{array}{r}\text { Natural } \\
\text { gas }\end{array}$ & Coal, coke & $\begin{array}{l}\text { District } \\
\text { Heating }\end{array}$ & RE & Other & In total & Source \\
\hline $\begin{array}{l}\text { Energy consump- } \\
\text { tion, primarily } \\
\text { agricultural (TJ) }\end{array}$ & 13,587 & 20,152 & 1,455 & 1,203 & 1,531 & 2,313 & 788 & 41,030 & $\begin{array}{r}\text { Landbrug \& } \\
\text { Fødevarer, } \\
2013 \text {, table } 3\end{array}$ \\
\hline $\mathrm{CO}_{2}(\mathrm{~kg} / \mathrm{TJ})$ & 55.9 & 74.0 & 57.0 & 100 & 34.0 & 0 & 0 & & $\begin{array}{r}\text { Energistyrelsen, } \\
2014\end{array}$ \\
\hline $\begin{array}{l}\text { Emissions (million } \\
\text { tonnes of } \mathrm{CO}_{2} \text { ) }\end{array}$ & 1.8 & 1.5 & 0.1 & 0.1 & 0.1 & 0.0 & 0.0 & 3.5 & \\
\hline
\end{tabular}

Energy consumption is calculated to be approximately $41 \mathrm{PJ}$ in 2011 (in agriculture and horticulture), of which approximately 13.6 PJ electricity (for heating, stationary machines, etc.), 20.2 PJ diesel (for mobile machinery) and 2.3 PJ from so-called renewable energy (RE), i.e. straw, wood, waste and biogas (Landbrug \& Fødevarer, 2013). The total emissions from energy consumption can be calculated to 3.5 million $\mathrm{CO}_{2} \mathrm{e}$ (see Table 2).

\section{Emissions associated with domestic production of fertilizers}

Virtually all fertilizers used in Denmark are made abroad (see section 2.2.). According to DCE48 a total of 0.0022 million tonnes $\mathrm{CO}_{2} \mathrm{e}$ were emitted from production of "Catalysts/Fertilisers" in Denmark. This emission is recognized under "Industrial Processes" in Figure 1. We do not know exactly what this category covers and whether it is related to agriculture, but as emissions in any case are relatively small, we choose to ignore it.

\section{Avoided emissions through the production of bioenergy}

Agriculture supplies energy to the community in the form of straw, biofuels, biogas and energy crops. Part of biogas is derived from waste from other sources than agriculture such as waste and sewage sludge. In the calculations in Table 3, we assume that biogas, which is not derived from landfills (landfill) or sludge, is attributable to agriculture.

With the assumptions below, we can calculate that Danish agriculture produces an amount of energy, which have displaced emissions of approx. 2.4 million tons of $\mathrm{CO}_{2}$, compared to if the energy had to be produced as Danish average (see Table 3). 


\begin{tabular}{|c|c|c|c|c|c|}
\hline & Unit & Electricity & $\begin{array}{l}\text { District } \\
\text { heating }\end{array}$ & Transport & Total \\
\hline Straw & TJ & 6,331 & 11,970 & 0 & \\
\hline Biofuels & TJ & - & 1,072 & 8,642 & \\
\hline Biogas & TJ & 2,301 & 1,504 & 0 & \\
\hline Energy crops & TJ & 476 & 476 & 0 & \\
\hline Energy delivery (total) & TJ & 9,109 & 15,022 & 8,642 & \\
\hline $\mathrm{CO}_{2}$-content & tons $\mathrm{CO}_{2} / \mathrm{TJ}$ & 135 & 36 & 73 & \\
\hline Displaced $\mathrm{CO}_{2}$-emission & Mio. tons $\mathrm{CO}_{2}$ & 1.2 & 0.5 & 0.6 & 2.4 \\
\hline
\end{tabular}

In Table 3, we have made the following assumptions:

- The consumption of straw, biofuels and biogas in industry and households is used for heating. Emissions of $\mathrm{CO}_{2}$ in the production of heat from these fuels correspond to emission ratios for district heating.

- All biogas produced that does not come from sludge or landfill is assumed to come from agriculture.

- The annual biomass production for energy crops is $7 \mathrm{t}$ dry matter/ha. The energy content is $16 \mathrm{GJ} /$ ton of dry matter.

- The production of energy from energy crops is divided equally between electricity and district heating. (This corresponds approximately to the distribution of the energy output from wood products).

- Emissions from indirect land use change (ILUC) related to the production of energy crops (including crops used as additional biomass to biogas production) are not included.

\section{Foreign emissions of greenhouse gases}

In addition to the domestic emissions, it is also necessary to include emissions associated with imported inputs, especially emissions from the production of imported feed, fertilizer, pesticides and possibly also machinery etc. if we want to have an accurate picture of the climate impact of Danish agricultural production. The two main categories are fertilizers and livestock feed.

Regarding livestock feed, we have only been able to find estimations of the primary crop, soya. CONCITO (2014) estimates the greenhouse gas impact of Danish imports of soybeans, which are primarily used for animal feed, to about 6 million tonnes of $\mathrm{CO}_{2} \mathrm{e}$. (CONCITO estimates in their calculations, net average emissions in the produc- 
tion of soy to approx. $3.8 \mathrm{~kg} \mathrm{CO} \mathrm{CO}_{2} \mathrm{e} / \mathrm{kg}$ of soy cake when indirect land use change is included).

We have not found estimations regarding the emissions related to imported fertilizers, but it is known that this production of is a source of emissions of both $\mathrm{CO}_{2}$ and $\mathrm{N}_{2} \mathrm{O}$. Agricultural consumption of $\mathrm{N}, \mathrm{P}$ and $\mathrm{K}$ was in 2011/2012 (as pure nutrients): 187,024 tonnes $N, 12,804$ tonnes $\mathrm{P}$ and 42,616 tonnes $\mathrm{K}$.

\section{Ammonia emissions}

Agriculture is the largest source of ammonia emissions, with a contribution of $96 \%$ of the total emissions. Most of the emissions are related to livestock production where ammonia is released from manure in animal housing, from the storage and spreading of manure and from grazing animals. Manure was in 2012 responsible for some $80 \%$ of total agricultural ammonia emissions. The remaining $15-20 \%$ have come from the spreading of fertilizers, growing plants, ammonia treated straw, field burning of crop residues and use of sewage sludge as fertilizer on the fields.

Agricultural emissions of ammonia decreased from $124 \mathrm{Gg}$ in 1990 to $73 \mathrm{Gg}$ in 2012, representing a reduction of $41 \%$ (see figure 5). The reduction is achieved through a series of policies over the period intended to reduce losses of nitrogen to the aquatic environment. A number of action plans have contributed to this: NPO Action Plan (nitrogen, phosphorus and organic matter) in 1986; the Water Environment Plans 1987, 1998 and 2004; Action Plan for Sustainable Agriculture from 1991 and the Ammonia Action Plan from 2001. These plans have resulted in better nitrogen utilization in animal production (and hence less emissions per unit of production - especially in the production of fattening pigs), reduced nitrogen loss from the manure and better utilization of the nitrogen in manure along with a decrease in the use of fertilizers. Together, these actions and the associated laws and regulations have reduced total ammonia emissions significantly.

The primary reasons for the decrease in emissions are: better utilization of nitrogen from both manure and mineral fertilizers and improved feed utilization in swine production. Following the Livestock Regulation (BEK, 2002), ammonia treatment of straw has been banned since August 2004. Furthermore, a ban on spreading manure on fields in winter and a ban on broad spreading of slurry have been introduced.

There is also legislation on nitrogen standards for various crops as well as requirements on plant cover/cover crops that can absorb excess 
nitrogen. (Bekendtgørelse af lov om jordbrugets anvendelse af gødning og om plantedække, 2013).

Figure 5: Emissions of ammonia in tonnes $\mathrm{NH}_{3}$. The category "Non-agricultural Sources" includes all emissions from the following sectors: Energy (including Mobile sources), Industry and Waste. The category "Other Agricultural Sources" is comprised of: Crops, Field Burning, Sewage Sludge, Ammonia Treated Straw. DCE $2014 b$

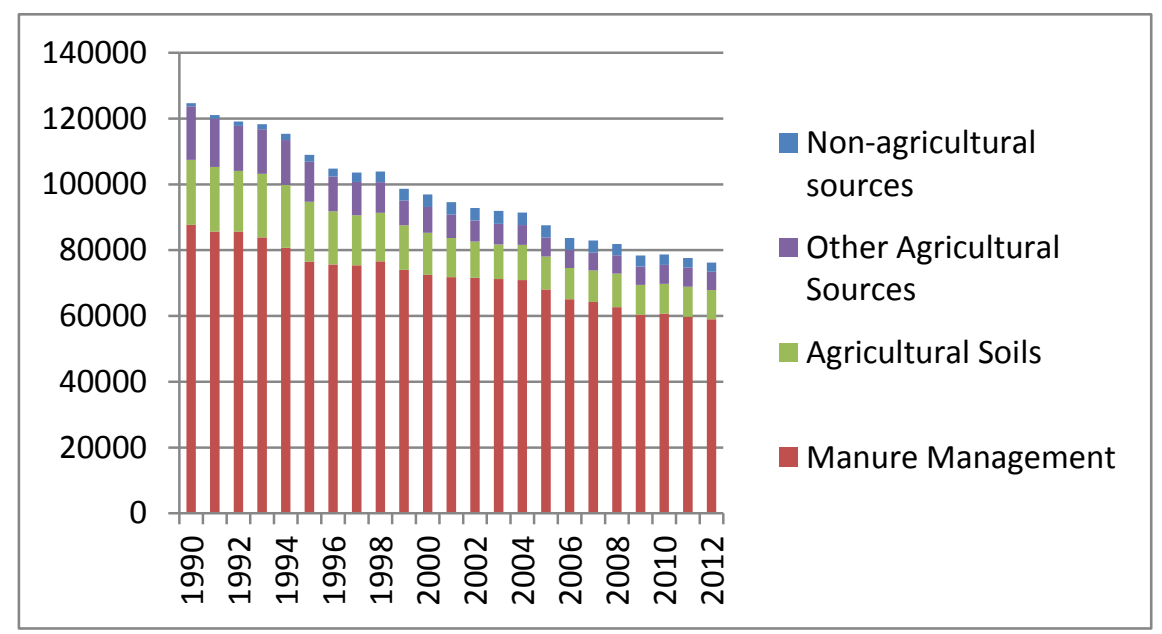

The EU Nitrate Directive is implemented in Denmark through regulation of fertilization, including fixed maximum nitrogen allocations and requirements regarding the use of manure. The "manure regulation" lays down a number of rules for storage and application of manure, which intends to reduce emissions and leaching of nitrogen (Bekendtgørelse om erhvervsmæssigt dyrehold, husdyrgødning, ensilage m.v., 2013):

Rules for storage of slurry and solid dung:

- There are requirements for the size of slurry tanks as well as the dunghill area. The capacity should normally correspond to at least 9 months' supply of manure/dung.

- Slurry containers must not be placed closer than 100 meters to open streams and lakes (larger than $100 \mathrm{~m}^{2}$ ). Containers shall be made of durable materials, which can resist penetration form moisture. Slurry tanks must be strong enough to withstand impact from machines in connection with pumping, stirring and draining.

- Slurry tanks must be covered with either: 1 ) a fixed cover e.g. a tent; 2) a natural floating layer, e.g. straw. 
If not covered ammonia-reducing technology should be applied.

- Some slurry tanks must always have a fixed cover. This applies if they are built closer than 300 meters from neighboring dwellings or certain types of habitats.

- Dunghill sites must be built following special regulations, e.g. constructed from a material that moisture cannot penetrate. The dung stack should usually be covered with a breathable material.

Rules for application of manure and sewage sludge:

- Animal manure applied to non-vegetated areas must be tilled into the soil as soon as possible and within 6 hours.

- Spreading must not be done in a way which induces a risk that the fertilizer can be washed into drains, streams or lakes, for example in the case of heavy rain or thawing.

- Application of liquid manure and degassed plant biomass has to be done by trailing hoses, injection or the like.

- Application onto black soil and permanent grass must be done with injection or with pretreated slurry.

- From harvest to 1st February, liquid manure may only be spread on selected crop types (fields with winter rape and some meadows).

- The maximum amount of manure allowed to be spread amount to the manure from 2.3 livestock units per hectare.

Figure 6: The annual ammonia emissions from the main livestock categories. Same total but other brake down than Figure 5. DCE 2014b

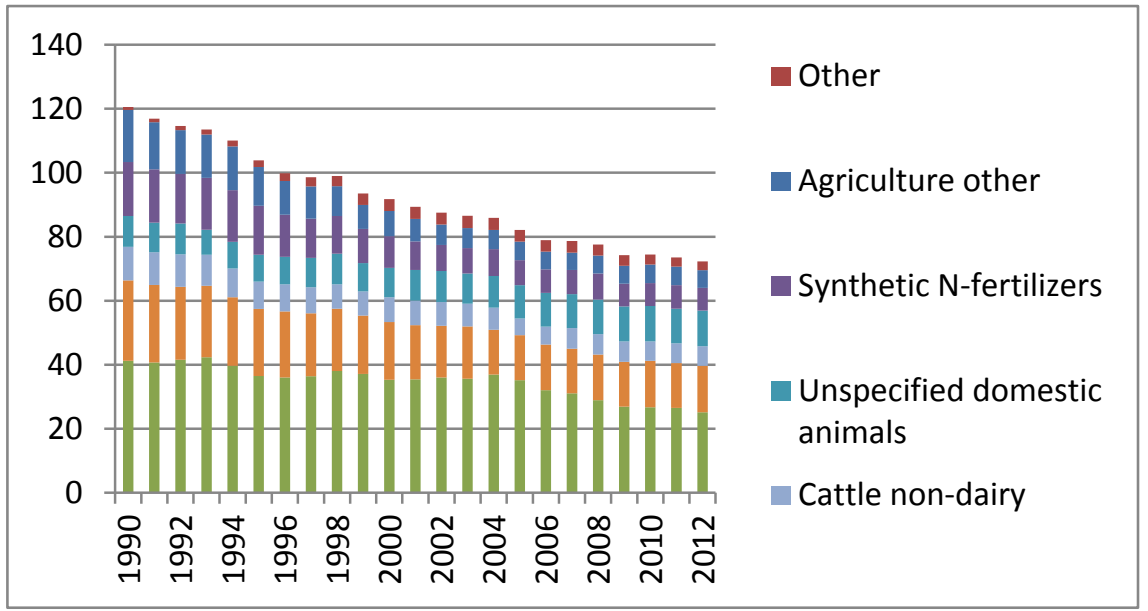


Most of the emissions come from cattle and pigs (see Figure 6). In 1990 cattle production was responsible for $29 \%$ and pigs for $33 \%$ of total emissions.

In 2012, the share of cattle had fallen to $27 \%$ (19\% from dairy/8\% from non-dairy), while the contribution from the pig production was still at $33 \%$. The contribution of emissions from mineral fertilizers has declined since 1990. It is noteworthy that the total emissions from pigs fell by 39\% between 1990 and 2012 despite a significant growth in pig production from 9.2 million pigs in 1989 to 12.3 million in 2009 (Table 1). One of the main reasons for this is a significantly increased efficiency in feed intake.

According to the Gothenburg Protocol, Denmark must reduce $\mathrm{NH}_{3}$ emissions by $24 \%$ over the period 2005-2020.

Currently, a revision of the NEC (National Emission Ceilings Directive) is negotiated at the EU level. The Commission has proposed a $24 \%$ and 37\% reduction for Denmark by 2020 and 2030 respectively compared to the base year 2005 (Claus Torp 2014).

The reason for keeping Denmark's reduction target fixed at $24 \%$ is DCE's projection for emissions of $\mathrm{NH}_{3}$ (DCE 7, 2012). DCE's projection was based on applicable regulatory and political agreements, i.e. the Green Growth agreement from 2009 (with follow-up in 2010 requiring a general reduction of ammonia when approving livestock farms), the Nitrates Directive, the Habitats Directive (with specific ceilings of deposition), NEC Directive, the Livestock Approval Act (application of liquid manure on black soil and grassland permitted only when incorporated into the soil) (Kirsten Brosbøl, 2014).

However, DCE made a new projection in 2013, which shows that Denmark would only reduce emissions by $15 \%$ compared to the base year with current regulatory and political agreements (DCE 81, 2013). The difference between projections for 2012 and 2013 is primarily due to an increase in the expected number of animals, and decreases in the number of buildings with $\mathrm{NH}_{3}$-reducing technology. DCE 81 (2013) provides no real justification for the increase in the expected number of animals, but the reduction in expected number of stables with $\mathrm{NH}_{3}$ reducing technologies is attributed to the economic recession.

\section{Projected emissions of greenhouse gases}

\section{Projections according to business as usual}

The report Projections of Greenhouse Gases 2011-2035 (DCE48) provides guidance for emissions of greenhouse gases from Danish agriculture 
based on the policies and measures that already were adopted by September 2012 (personal communication with Ole-Kenneth Nielsen). This can be considered a business as usual scenario (BAU). However, this scenario goes further in biogas production than what is actually decided, assuming that $75 \%$ of the slurry will be anaerobically digested to biogas, while the current politically agreed intention (from Energiaftalen 2012) is that up to $50 \%$ of the manure should be used for biogas production.

The trend towards larger farms with higher productivity, compared with today's average is in this scenario expected to continue. This is predicted to lead to increased production efficiency, improved feed efficiency and better use of nitrogen in livestock manure - all measures that reduce emissions. Furthermore establishing biogas plants is expected to an extent, which, as mentioned earlier, goes further than already agreed goals. The expectation is also that strengthened environmental requirements at both Danish and EU level will help to reduce emissions, including some change from annual crops to pastures. On the other hand, there is also an expectation of trends that will increase emissions, for example a continued deterioration of the organic material in the soil and increased methane emissions due to increased milk production. Furthermore, it is pointed out that the import/export conditions will continue to play a crucial role.

In this chapter, the new IPCC factors for GWP, i.e. $298 \mathrm{CO}_{2}$ e for $\mathrm{N}_{2} \mathrm{O}$ and $25 \mathrm{CO}_{2} \mathrm{e}$ of $\mathrm{CH}_{4}$, are used as it describes a future situation. Therefore, the figure for nitrous oxide is lower than with the previously used conversion factor for nitrous oxide (section 2.1.1.), while the figure for methane is higher than with the previously used conversion factor for methane (section 2.1.2). The 2012 figures are as follows with the previously used conversion factors: approx. 5.4 million tonnes $\mathrm{CO}_{2} \mathrm{e}$ for nitrous oxide and approx. 4.2 million tonnes of $\mathrm{CO}_{2} \mathrm{e}$ for methane. With the new conversion factors the figures are approx. 5.3 million tonnes $\mathrm{CO}_{2} \mathrm{e}$ for nitrous oxide and approx. 4.9 million tonnes of $\mathrm{CO}_{2} \mathrm{e}$ for methane.

\begin{tabular}{lrrrrr} 
Table 4: Historical and current emissions of greenhouse gases from Danish agriculture. (DCE48) \\
Million tonnes $\mathrm{CO}_{2}$ ekv./year & $\mathbf{1 9 9 0}$ & $\mathbf{2 0 0 0}$ & $\mathbf{2 0 1 0}$ & $\mathbf{2 0 1 1}$ & $\mathbf{2 0 1 2}$ \\
& & & & & \\
$\mathrm{CH}_{4}$ & 5.05 & 4.82 & 4.94 & 4.88 & 4.87 \\
$\mathrm{~N}_{2} \mathrm{O}$ & 7.90 & 6.10 & 5.16 & 5.19 & 5.26 \\
Soil C (Cropland and grassland) & 5.05 & 3.79 & 3.37 & 3.56 & 3.54 \\
Total $\left(\mathrm{CH}_{4}+\mathrm{N}_{2} \mathrm{O}+\mathrm{C}\right)$ & 18.00 & 14.71 & 13.47 & 13.62 & 13.67 \\
\hline
\end{tabular}




\begin{tabular}{lrrrr} 
Table 5: Future emissions according to the scenario described until & $\mathbf{2 0 3 0}$. (DCE48) \\
Million tonnes $\mathrm{CO}_{2}$ ekv./year & $\mathbf{2 0 1 5}$ & $\mathbf{2 0 2 0}$ & $\mathbf{2 0 2 5}$ & $\mathbf{2 0 3 0}$ \\
$\mathrm{CH}_{4}$ & 4.76 & 4.72 & 4.79 & 4.86 \\
$\mathrm{~N}_{2} \mathrm{O}$ & 4.96 & 4.74 & 4.68 & 4.61 \\
Soil C (Cropland og grassland) & 3.52 & 3.45 & 3.42 & 3.35 \\
Total $\left(\mathrm{CH}_{4}+\mathrm{N}_{2} \mathrm{O}+\mathrm{C}\right)$ & 13.24 & 12.92 & 12.89 & 12.82 \\
\hline
\end{tabular}

\section{Nitrous oxide, $\mathrm{N} 20$}

The historic reductions in nitrous oxide emissions (as described in Section 3.1.1.) are achieved mainly as a result of the lowered nitrogen standards and improved manure management as well as improved nitrogen utilization in animal manure (which has resulted in reduced use of mineral fertilizers and reduced nitrogen leaching). At the same time the agricultural area has decreased by more approx. $4 \%$.

In the BAU scenario, it is expected that in the future the largest reductions will be achieved through continued improvements in manure management and thus increased/improved manure application. As a consequence there will be a continued decline in the use of mineral fertilizers, which at the same time will reduce emissions related to nitrogen leaching. The current trend in relation to the reduction of the agricultural area is expected to continue; particularly organic soils are expected to be removed from production. No changes in nitrogen standards are assumed in this scenario. The decrease in nitrous oxide emissions from 1990 to 2010 is in the scenario (DCE48) expected to continue but at a slower pace. The expected result of the projected initiatives would reduce nitrous oxide emissions by around $13 \%$, i.e. a decrease from 5.3 million tonnes $\mathrm{CO}_{2} \mathrm{e}$ in 2012 to 4.6 million tonnes $\mathrm{CO}_{2} \mathrm{e}$ in 2030 .

The reduction is mainly related to the following:

- Improved manure management, such as:

- more nitrogen retained in the manure during storage and reduced ammonia volatilization from the stables

○ cooling of pig slurry in the stables, covering the slurry containers, covering of solid manure

○ a high proportion of slurry processed to biogas (75\%).

- A decrease in the use of mineral fertilizers (which is primarily attributable to the reduction of agricultural area, and the improved nitrogen efficiency from manure due to better manure management). 
- Reduced nitrogen leaching (which is primarily attributable to the reduced use of mineral fertilizers).

- Increased withdrawal of organic soils from cultivation (drained peat soils with at least $12 \%$ organic matter in the plough layer).

Figure 7: Projected $\mathrm{N}_{2} \mathrm{O}$ emissions from the agricultural sector, given in $\mathrm{CO}_{2}$ equivalents. (DCE48)

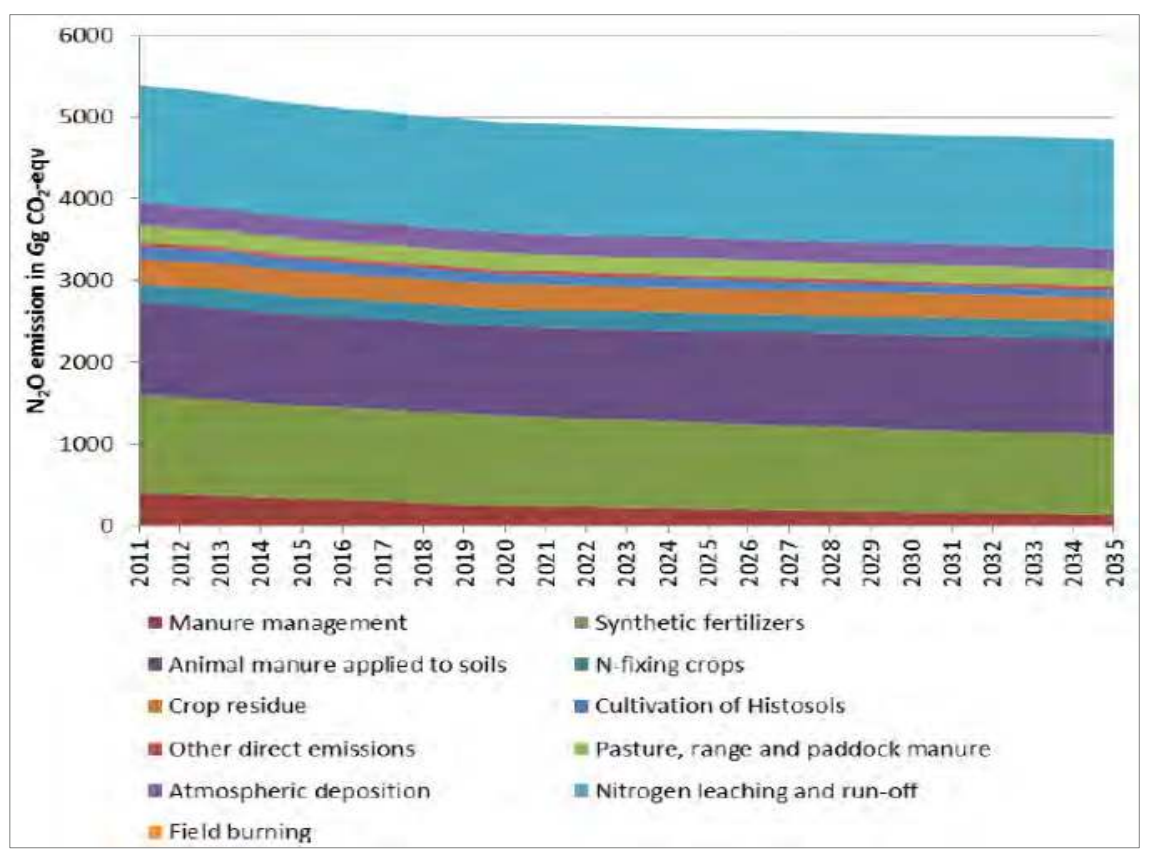

Figure 7 shows that the largest reductions are achieved by continued improvements in manure management in parallel with the continued decline in the use of mineral fertilizers; this will at the same time reduce GHG emissions related to nitrogen leaching. In addition some reductions are achieved when more organic soils (histosols) are taken out of production.

\section{Methane, $\mathrm{CH}_{4}$}

As described in in Section 3.1.2., the total historical emissions of methane from agriculture remained virtually constant over the period 1990-2012. However, this contains some changes, namely that emissions from ruminants has decreased slightly due to a decrease in the number of dairy cattle, but this reduction is of-set by emissions from manure management that has increased due to the transition from solid manure to (more) slurry. 
In the future, total methane emissions are expected remain relatively unchanged until 2035 (see Figure 8). The underlying expectation is mainly based on three assumptions:

- The number of dairy cattle is expected to be unchanged from 2013 to 2035. This will, by continuously increasing milk yields per cow (achieved through increased feed consumption) lead to rising emissions from cows' digestion. (Until 2013, EU's milk quota determined the total production of milk; dairy cow numbers therefore decreased as the yield per cow increased. After the termination of the quota system, it is expected that the total milk production will increase. An increase in milk production per cow of $1.5 \%$ per year until 2020 is expected, and after 2020 1.25\% per year).

- Methane emissions from the handling of manure have increased from 1990 to 2010 due to changes in housing systems towards more slurry-based systems. From 2020, it is expected that the manure of all dairy cattle can be handled as slurry.

- The reduced emissions that result from digestion of manure to biogas is assumed to have a significant impact in relation to emissions from manure handling (see Figure 8). In this scenario (DCA48) it is assumed that approximately $75 \%$ of the manure will be anaerobically digested, reducing the total methane emissions in this scenario. If this implementation of biogas production from slurry is not completed, the reduction in $\mathrm{CH}_{4}$ emissions from manure management will be lower and the total $\mathrm{CH}_{4}$ emissions is therefore likely to be increased by 2030 compared to current emissions.

- Million tonnes in 2015 and 0.27 million tonnes in 2030). If this implementation of biogas production from slurry is not completed, methane emissions are likely to be increased in 2030 compared to current emissions. 
Figure 8: Projected $\mathrm{CH}_{4}$ emission from the agricultural sector, given $\mathrm{CO}_{2}$ equivalents. (DCE48)

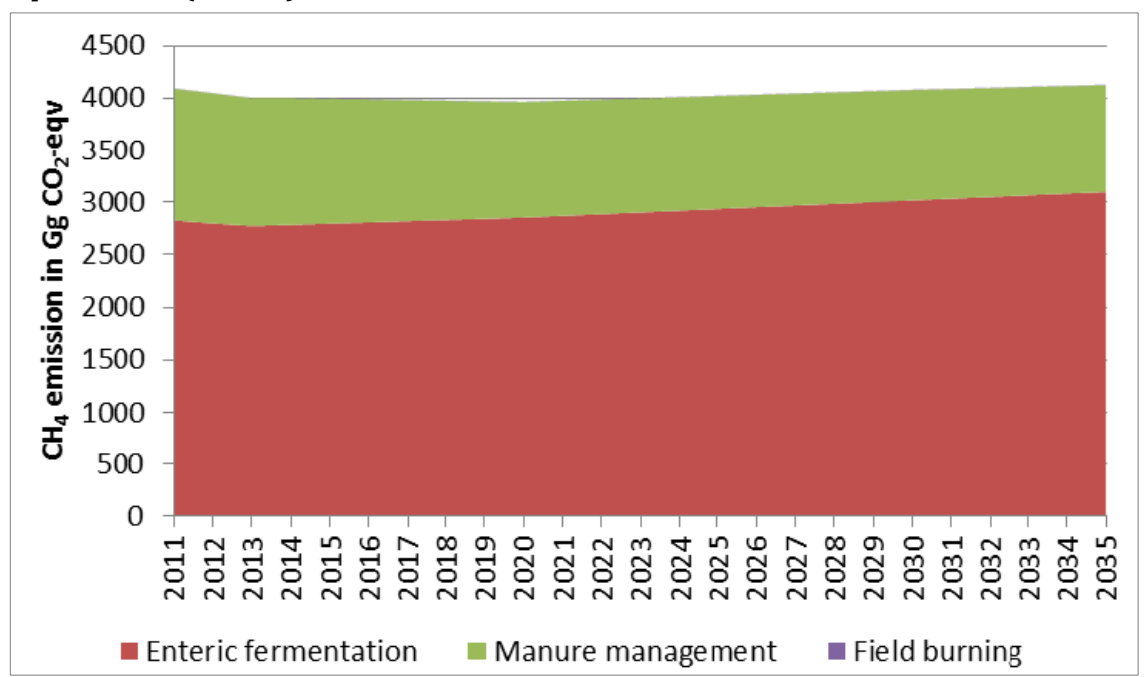

\section{LULUCF}

As described in Section 3.1.3., historic reductions related to agriculture's emissions from LULUCF (from cropland and grassland) is mainly due to reduction of the cultivated area (in rotation with annual crops), the ban on field burning of straw (introduced in 1990), and, probably also, to extremely low content of organic material in many soils, which in itself has led to reduced degradation and thereby reduced emissions. Alongside these reductions, however, there has been a continued degradation of the organic material in the farmland on both mineral and organic soils - a trend that is expected to continue.

It is expected that in the future the annual loss from the mineral soils will be in the same order of magnitude as currently while the annual emissions from organic soils will be slightly reduced, which is a consequence of the progressively reduced content of organic matter in the organic soils.

It is estimated that there will still be a continued annual loss resulting in the release of approximately 1.35 million tonnes $\mathrm{CO}_{2} \mathrm{e}$ from the mineral soils. This loss depends on the temperature and the yields, as well as on the amount of manure, straw and other crop residues that is removed to be used for other purposes. Furthermore, emissions from organic soils must be added; these are expected to be slightly lower than the current 1.87 million tonnes $\mathrm{CO}_{2}$ e per year.

In DCE48 it is assumed that there will be a shift from land in rotation to perennial grassland, termination of cultivation of some organic soils, and that there is a re-establishment of wetlands on agricultural land 
which will absorb carbon as it is expected that continued plant growth will occur in some of these wetlands (in the order of about 40,000 ha (in addition to the buffer zones)). The latter removals are reported under "Wetlands" in Figure 4, and are thus not included in Table 5.

50,000 hectares were set aside for uncultivated 10 meter wide buffer zones (that may not be plowed, fertilized or sprayed) along creeks and streams. Previously these zones were 2 meter wide. The initiative should have been implemented by the end of 2012. But in the spring of 2014, the rules were changed reducing the width of buffer zones to $9 \mathrm{~m}$ and do now not apply everywhere. Consequently the expected emission reductions from this measure will be smaller than assumed in Table 5 .

Future reductions in soil carbon emissions may be achieved by taking more land (with annual crops) out of rotation and used for other purposes such as nature conservation, permanent grassland and perennial crops or by increased cultivation of catch crops and intercrops.

\section{Further measures}

Researchers from Aarhus University have looked at a number of actions to reduce the emission of greenhouse gases from Danish agriculture, described in "Effects of measures to reduce agricultural emissions of greenhouse gases" (DCA27, 2013), which goes beyond the projection in DCE48. DCA27 describes the combined emissions of methane and nitrous oxide, as well as changes in soil carbon content (soil-C). In addition, the report describes the potential for energy production based on agricultural products.

The report does not take into account greenhouse gas emissions connected to those excipients that Danish agriculture imports from abroad, even though e.g. the proposed conversions of land for energy crops could potentially lead to increased imports of animal feed if animal production is not reduced. The following table from the report shows the expected reductions of a number of measures (in a given magnitude) when the climatic effect of substitution of fossil fuels with biofuels is included. The figures are not in all cases an adequate description. For example, in some places (e.g. under biogas from maize), a zero is indicated under soil-C, where an emission should have been registered, but where the authors do not know the order of magnitude. 
Table 6: Estimates of the reduction in greenhouse gas emissions by 2020 compared to the baseline scenario (1.000 tonnes $\mathrm{CO}_{2} \mathrm{e} /$ year). (DCA27)

\begin{tabular}{|c|c|c|c|c|c|c|c|}
\hline Measure & Magnitude & $\begin{array}{r}\mathrm{CH} 4+ \\
\mathrm{N} 2 \mathrm{O}\end{array}$ & Soil-C & $\begin{array}{r}\mathrm{CH} 4+ \\
\mathrm{N} 2 \mathrm{O}+\mathrm{C}\end{array}$ & $\begin{array}{r}\text { Bio- } \\
\text { energy }\end{array}$ & $\begin{array}{l}\text { Incl. C- } \\
\text { storage }\end{array}$ & $\begin{array}{l}\text { Excl. C- } \\
\text { storage }\end{array}$ \\
\hline Straw as fuel in CHP & 100,000 ha & 11 & -74 & -63 & 159 & 96 & 169 \\
\hline $\begin{array}{l}\text { Straw for thermal gasification, } \\
\text { returning biochar to the soil }\end{array}$ & 100,000 ha & 11 & -59 & -48 & 256 & 208 & 267 \\
\hline Biogas from manure & $\begin{array}{l}10 \% \text { of the } \\
\text { liquid manure }\end{array}$ & 85 & -6 & 79 & 79 & 158 & 164 \\
\hline $\begin{array}{l}\text { Biogas from manure with } \\
\text { separation }\end{array}$ & $\begin{array}{l}10 \% \text { of the } \\
\text { liquid manure }\end{array}$ & 51 & -5 & 47 & 64 & 111 & 116 \\
\hline Biogas from nature grassland & 5,000 ha & -6 & 0 & -6 & 35 & 29 & 29 \\
\hline Biogas from maise & 60,000 ha & -66 & 0 & -66 & 402 & 336 & 336 \\
\hline $\begin{array}{l}\text { Biogas from organic } \\
\text { clover/grass }\end{array}$ & 20,000 ha & -12 & 37 & 25 & 72 & 97 & 60 \\
\hline $\begin{array}{l}\text { Biogas from conventional } \\
\text { festulolium }\end{array}$ & 60,000 ha & -96 & 110 & 14 & 298 & 313 & 203 \\
\hline $\begin{array}{l}\text { Acidification of manure in } \\
\text { the stables }\end{array}$ & $\begin{array}{l}10 \% \text { of the } \\
\text { liquid manure }\end{array}$ & 102 & 0 & 102 & 0 & 102 & 102 \\
\hline $\begin{array}{l}\text { Acidification of slurry in } \\
\text { the store }\end{array}$ & $\begin{array}{l}5 \% \text { of the } \\
\text { liquid manure }\end{array}$ & 41 & 0 & 41 & 0 & 41 & 41 \\
\hline Covering slurry tanks & $\begin{array}{l}40 \% \text { of the } \\
\text { liquid manure }\end{array}$ & 82 & 0 & 82 & 0 & 82 & 82 \\
\hline $\begin{array}{l}\text { Cooling of manure in pig } \\
\text { housing }\end{array}$ & $\begin{array}{l}10 \% \text { of the } \\
\text { liquid manure } \\
\text { from pigs }\end{array}$ & 6 & 0 & 6 & 0 & 6 & 6 \\
\hline $\begin{array}{l}\text { Fat/altered feeding for dairy } \\
\text { cows (without side effects) }\end{array}$ & $\begin{array}{l}80 \% \text { of the } \\
\text { dairy cow herd }\end{array}$ & 143 & 0 & 143 & 0 & 143 & 143 \\
\hline $\begin{array}{l}\text { Fat/altered feeding to other } \\
\text { cattle (without side effects) }\end{array}$ & $\begin{array}{l}25 \% \text { of the } \\
\text { herd }\end{array}$ & 13 & 0 & 13 & 0 & 13 & 13 \\
\hline Nitrate feeding of dairy cows & $\begin{array}{l}10 \% \text { of the } \\
\text { herd }\end{array}$ & 27 & 0 & 27 & 0 & 27 & 27 \\
\hline $\begin{array}{l}\text { Prolonged lactation in dairy } \\
\text { cows }\end{array}$ & $\begin{array}{l}10 \% \text { of the } \\
\text { dairy cow herd }\end{array}$ & 18 & 0 & 18 & 0 & 18 & 18 \\
\hline $\begin{array}{l}\text { Nitrification inhibitors to } \\
\text { fertilizers }\end{array}$ & $\begin{array}{l}100 \% \text { of } \\
\text { fertilizers }\end{array}$ & 335 & 0 & 335 & 0 & 335 & 335 \\
\hline $\begin{array}{l}\text { Nitrification inhibitors to } \\
\text { manure }\end{array}$ & $\begin{array}{l}10 \% \text { of the } \\
\text { manure }\end{array}$ & 36 & 0 & 36 & 0 & 36 & 36 \\
\hline $\begin{array}{l}\text { Intensified } \mathrm{N} \text { - utilization } \\
\text { requirements after digestion of } \\
\text { manure }\end{array}$ & $\begin{array}{l}50 \% \text { of the } \\
\text { manure }\end{array}$ & 48 & 0 & 48 & 0 & 48 & 48 \\
\hline $\begin{array}{l}\text { Intensified } \mathrm{N} \text {-utilization } \\
\text { requirements for selected types } \\
\text { of manure }\end{array}$ & $\begin{array}{l}\text { Tightening } \\
\text { compared to } \\
\text { VMPIII }\end{array}$ & 17 & 0 & 17 & 0 & 17 & 17 \\
\hline
\end{tabular}




\begin{tabular}{|c|c|c|c|c|c|c|c|}
\hline Measure & Magnitude & $\begin{array}{r}\mathrm{CH}_{4}+ \\
\mathrm{N} 2 \mathrm{O}\end{array}$ & Soil-C & $\begin{array}{r}\mathrm{CH} 4+ \\
\mathrm{N} 2 \mathrm{O}+\mathrm{C}\end{array}$ & $\begin{array}{l}\text { Bio- } \\
\text { energy }\end{array}$ & $\begin{array}{l}\text { Incl. C- } \\
\text { storage }\end{array}$ & $\begin{array}{l}\text { Excl. C- } \\
\text { storage }\end{array}$ \\
\hline Reduced nitrogen standard & $10 \%$ reduction & 175 & 0 & 175 & 0 & 175 & 175 \\
\hline More legumes in pasture land & 200,000 ha & 95 & 0 & 95 & 0 & 95 & 95 \\
\hline Energy willow, organic soil & 10,000 ha & 2 & 12 & 14 & 4 & 18 & 6 \\
\hline Energy willow, clay soil & 10,000 ha & 2 & 12 & 14 & 4 & 18 & 6 \\
\hline Energy willow, sandy soil & 80,000 ha & 20 & 96 & 116 & 30 & 145 & 49 \\
\hline Catch crops, clay soil & 63,000 ha & 0 & 46 & 46 & 0 & 46 & 0 \\
\hline Catch crops, sandy soil & 177,000 ha & -20 & 130 & 110 & 0 & 110 & -20 \\
\hline Middle crops, clay soil & 110,000 ha & -3 & 81 & 78 & 0 & 78 & -3 \\
\hline Middle crops, sandy soil & 130,000 ha & -7 & 95 & 89 & 0 & 89 & -7 \\
\hline $\begin{array}{l}\text { Substitute cropping with } \\
\text { grassland in highlands, clay }\end{array}$ & 50,000 ha & 39 & 92 & 131 & 15 & 146 & 54 \\
\hline $\begin{array}{l}\text { Substitute cropping with } \\
\text { grassland in highlands, sand }\end{array}$ & 50,000 ha & 43 & 92 & 135 & 15 & 135 & 43 \\
\hline $\begin{array}{l}\text { Substitute cropping of organic } \\
\text { soils with grassland, continuous } \\
\text { drainage }\end{array}$ & 35,000 ha & 27 & 64 & 91 & 11 & 101 & 37 \\
\hline $\begin{array}{l}\text { Substitute cropping of organic } \\
\text { soils with grassland, termination } \\
\text { of drainage }\end{array}$ & 35,000 ha & 104 & 366 & 470 & 11 & 481 & 115 \\
\hline Sustained meadows & 90,000 ha & -6 & 66 & 60 & 0 & 60 & -6 \\
\hline Afforestation, clay soil & 31,000 ha & 24 & 80 & 103 & 9 & 113 & 33 \\
\hline Afforestation, sandy soil & 19,000 ha & 16 & 49 & 64 & 6 & 70 & 21 \\
\hline Reduced tillage & 200,000 ha & 0 & 66 & 66 & 8 & 74 & 8 \\
\hline In total & & 1357 & 1349 & 2706 & 1476 & 4182 & 2833 \\
\hline $\begin{array}{l}\text { In total taking into account the } \\
\text { interaction }\end{array}$ & & 1148 & 946 & 2094 & 802 & 2896 & 1950 \\
\hline
\end{tabular}

See also chapter 6 "Measures to reduce emissions" in "Nordic agriculture air and climate - Baseline and system analysis report" for our evaluation of measures to reduce agricultural emissions. It should be noted that we do not support the production of bioenergy undermining the soil carbon stock. 


\section{Future measures to reduce ammonia emissions and leaching}

Acidification of slurry and covering of slurry tanks are the steps that will both reduce greenhouse gases and ammonia. Acidification, which is a relatively cheap solution, is described and evaluated in a separate document. Cleaning the ventilation air from livestock buildings can reduce emissions of ammonia from the stables, but it is a relatively expensive option. Cooling of manure and floors in housing will also reduce ammonia emissions. Better coverage of manure heaps is also an opportunity to reduce emissions of ammonia. Increased slurry injection could also reduce the evaporation of ammonia.

There is evidence that suggest that biogas treatment increases the release of ammonium. Among other things, the organic substances are degraded, whereby the propensity to form floating crusts decreases. In addition, the $\mathrm{pH}$ increases, which increases the conversion of ammonium $\left(\mathrm{NH}_{4}\right)$ to ammonia $\left(\mathrm{NH}_{3}\right)$. Yet it is difficult to be sure whether an increased biogas production will lead to increased or decreased emissions of ammonia. For example, the digested slurry becomes more fluid, and thereby penetrates into the soil faster, when it is spread on the fields. See chapter 6.3.3. Case Study On Biogas Production In Denmark in "Measures to reduce emissions" in "Nordic agriculture air and climate Baseline and system analysis report" for a further evaluation of biogas.

In addition to legislative measures described in 3.3, there are a number of support schemes aimed directly towards reducing leaching of nitrogen, e.g.:

- Support for the establishment of wetlands where fertilizing is not allowed (for a period of at least 5 years).

- Supplementary support for reduced nitrogen inputs on farms that already receive subsidies for organic farming.

\section{Support schemes}

A somewhat promising public support program for developing a sustainable food and farming system is The Green Development and Demonstration Programme (GUDP) under The Danish AgriFish Agency, who presents the program as follows: "GDDP is a modern support system addressing some of the key challenges for the food sector and the whole society. The challenge is to create a greater sustainability, while solving some of the climate and environmental problems facing society - 
while at the same time the economy is improving, so that the food sector continuously can generate growth in Denmark and secure jobs".

Hopefully, the Agency will in the future allocate funds for developing innovative local food and farming systems based on e.g. permacultural practices, agroecology and food sovereigty.

\section{Conclusions}

The combined actions of business as usual and the additional actions described above will only lead to modest reductions in domestic emissions of only about 3 million tons of $\mathrm{CO}_{2} \mathrm{e} /$ year, and smaller reductions in imports of fertilizers and feed, which is far from the goals we want.

We assume that it will not be possible to increase yields without increasing pressure on nature, the environment and the climate when land is set aside for afforestation and permanent grass and possibly bioenergy. Agricultural production will therefore be reduced. We suggest that it is the production of fodder and thus animal production, which will be reduced when these land-use changes take place.

We assume further that it is not possible to increase the output per unit of feed in livestock without inflicting a negative impact on animal welfare and health. It would not make sense continuously to base animal production on imported soy feed with a very negative impact on both climate and environment. We therefore assume that soybean imports are reduced parallel to the Danish feed production. The overall result will be that the production of livestock will fall proportionally as agricultural land is converted to forest and various permanent grasslands.

For further reductions more radical structural measures will be needed such as reducing exports of animal products further and developing a new understanding of diet and consumption (both nationally and globally), in order to achieve that the consumption of animal products, and other agricultural products with a high climate-impact, is reduced.

Many of the measures that can be implemented to reduce the emission of greenhouse gases will also have a positive effect on ammonia emissions and vice versa. Unfortunately, it has not been possible to find references that provide a quantitative assessment of how much each measure impact on ammonia emissions. 


\section{Tables and figures}

\section{Tables}

Table 1. Number of animals in Danish agriculture.

Table 2. Calculation of emissions from energy consumption in agriculture in 2011 $(\mathrm{RE}=$ renewable energy).

Table 3. Calculation of avoided $\mathrm{CO}_{2}$-emissions from producing energy from Danish agricultural crops and residues in 2012. Energistyrelsen, 2014 / DCA101.

Table 4: Historical and current emissions of greenhouse gases from Danish agriculture. (DCE48).

Table 5: Future emissions according to the scenario described until 2030. (DCE48).

Table 6: Estimates of the reduction in greenhouse gas emissions by 2020 compared to the baseline scenario (1.000 tonnes $\mathrm{CO}_{2} \mathrm{e} /$ year). (DCA27).

\section{Figures}

Figure 1. Greenhouse gas emissions in $\mathrm{CO}_{2}$-equivalents distributed on main sectors and for the time-series 1990-2012 (million tonnes $\mathrm{CO}_{2}$ equivalents). DCE 2014a.

Figure 2. Nitrous oxide emissions in Denmark 1990-2012 in 1000 tonnes. (Danish production of nitric acid stopped in 2004 and the emissions from industrial processes is therefore not occurring from 2005 onwards). DCE 2014a.

Figure 3. Methane emissions in Denmark for 1990-2012, measured in 1000 tonnes. DCE 2014a.

Figure 4. LULUCF in $\mathrm{CO}_{2}$-equivalents distributed on main land uses and time-series (mio. tonnes $\mathrm{CO}_{2}$ equivalents). Eionet 2014.

Figure 5: Emissions of ammonia in tonnes $\mathrm{NH}_{3}$. The category "Non-agricultural Sources" includes all emissions from the following sectors: Energy (including Mobile sources), Industry and Waste. The category "Other Agricultural Sources" is comprised of: Crops, Field Burning, Sewage Sludge, Ammonia Treated Straw. DCE 2014b.

Figure 6: The annual ammonia emissions from the main livestock categories. Same total but other brake down than Figure 5. DCE 2014b.

Figure 7. Projected $\mathrm{N}_{2} \mathrm{O}$ emissions from the agricultural sector, given in $\mathrm{CO}_{2}$ equivalents. (DCE48).

Figur 8. Projected $\mathrm{CH}_{4}$ emission from the agricultural sector, given $\mathrm{CO}_{2}$ equivalents. (DCE48). 



\section{Annex 2: National Report: Agriculture in Norway}

Project: "Pathways to a Nordic food system that contributes to reduced emissions of greenhouse gases and air pollutants".

\section{Introduction}

This national report constitutes an output under the project "Pathways to a Nordic food system that contributes to reduced emissions of greenhouse gases and air pollutants." This project is financed by the Nordic Minister Council and commenced in 2013. This report is an annex to the comprehensive Nordic report and much of the data for Norway was extracted from this national report. This national report mainly focuses on the national agricultural structures, land area use, agricultural production and current and projected greenhouse gas and ammonia emissions.

The main author of this report is Stein Brubæk. Kajsa Lindqvist and Miriam Márkus-Johansson contributed to the finalisation of this report.

\section{A brief description of the agricultural sector}

\section{Area}

In total the country has a defined agricultural territory of 9,917 ha. This represents only 3.3\% of Norway's total land area. Out of these $3.3 \%$ the agricultural land use is divided between $1.2 \%$ for corn and oilseeds, $1.5 \%$ cultivated grasslands and $0.6 \%$ natural pastures.

\section{Structural development}

Norway is a difficult country for agricultural production given the great variation in climatic and natural conditions. The difference between growing periods is ranging from 8-2 months. The territories around the Oslo fjord, on Jæren and Trøndelag, are the best agricultural areas 
with conditions that greatly resemble the rest of Europe. In fjord areas, inland and to the north, however, nature is more mountainous and there are many places with short summers and sometimes with extreme weather in the form of precipitation (rain and snow) and cold. In most areas Norwegian agriculture is characterised by many small and steep plots that are far apart and difficult to operate efficiently with modern machinery. There has been a significant structural change in Norwegian agriculture during the last 30 years and the number of farms has dropped by half. That has caused long distances between plots and the result is that manure being transported thousands of kilometres per year.

\section{Agricultural production}

Out of 44,000 farms with agricultural production in 2012, 31\% are of a territory less than 10 ha whereas $61 \%$ are in the range between $10-50$ ha and only $8 \%$ larger farms with a land territory exceeding 50 ha.

12,477 farms grow grains and oilseeds on a total territory of 299,000 ha. A further 3,236 farms grow potatoes and vegetables on a total area of 19,792 ha. The remaining 34,406 farms grow grass or fruit on a total area of 648,800 ha.

The farming activities and the number of livestock can be broken down accordingly:

- 9,951 farms are engaged in milk production with 233,000 dairy cows.

- 14,450 farms have 903,000 sheep.

- 5,091 farms have some 73,000 beef cows.

- 1,274 farms have 94,000 sows and 3,941,000 piglets.

- 2,380 farms have 60,329,000 poultry, out of which 4 million are laying hens and 56 million chickens.

Totally these farms produce approximately 1,531.2 million kilograms milk, 61.8 million kilogram eggs, 78 million kilogram beef, 131.6 million kilogram pork, 22.8 million kilogram sheep and lamb and 91.2 million kilogram poultry meat. In addition, 1,026.7 million kilogram grains and 298.2 kilogrammes of potatoes are produced.

There is a widespread abandonment of Norwegian farms. This must be viewed in the context of the economic situation in Norway with stable economic growth and an abundance of alternative better paid work throughout the country. 
During the last 30 years the Norwegian agriculture has seen a significant structural change with a $50 \%$ decrease in the number of farms (about 44,000 in 2012). The change is particularly stark in milk production and in feed intensive production. Average herd in milk production has increased from 16 to 25 cows in the last 10 years. There are currently many coowned barns with between 50-100 cows. The milk quota ceiling for a single holding used to be 400 tons, whereas 750 tons for cooperatives. After negotiations in 2014, this increased to 900 tons equally for both single holdings and cooperatives. This has resulted an increased number of dairy farms without grazing, where cows are fed up to $40 \%$ concentrated feed, and highly mechanized farms with milking robots.

Investment has been significant in Norwegian dairy farming in recent years. However large investments require also high yields of each individual farmer. The performance per cow has increased dramatically and some animals produce more than 50 litres of milk per day, i.e. over 10,000 litres per lactation. This has greatly affected farming activities e.g. the increased use of concentrated feed is at the expense of Norwegian grown roughages and the animals access to grazing. This performance is most common in farms with robots where cows decide themselves to be milked 3-4 times daily.

Within all districts there has been a transition from small to large farms, though there has not been that big redistribution of farming activities between regions. Grain and sheep production is maintained at similar levels, though farms are bigger than before.

The level of dairy production has not changed much either. Milk quotas have so far only been tradable within a region, which have prevented geographical concentration. However beef as by-product from dairy production has decreased in the past decades, since there has been a dramatic increase in milk productivity per cow. Fewer cows can now produce the same amount of milk as before, but fewer calves that will go to meat production are born. Specialized beef production has not been able to replace this drop. This has along with an increased demand resulted in a considerable increase in import of beef.

Pig and poultry production has increased significantly. Since this production is completely detached from the land you can see a concentration of production to Eastern Norway, Jæren and Trøndelag.

When districts with less favourable topographical conditions for big scale milk production keep their share of milk production, there are some adverse results in terms of transports. The farms have in the same time as they purchased milk quotas also leased land for growing grass and spreading of livestock manure that can be at great distance from the 
farm. It has become common for an individual farm to use up to 50 different, including some small plots, spread in an area of over $40-50 \mathrm{~km}$ away from the farm. Getting all the manure to the fields might require driving a tractor and manure wagon up to $4,800 \mathrm{~km}$ a year. This is the distance from Mid-Norway to Morocco. It is not uncommon for farmers to spend 1,800 hours on tractor a year. This represents the number of hours for one man. With the new quota rules these conditions may worsen since there is no set distance requirements for the area in relation to the farm, even though the political rationale for the quota increase is to provide this opportunity to farms that have sufficient resource base for it. Nor are there any calculations as to financial sustainability of the high number of transport.

This, in turn, is not compensated by specialized beef meat production leading to an increase in imported beef.

However, there has been a dramatic increase and redistribution between districts regarding pork, which has been concentrated to Jæren. This is becoming a more specialized production, which not necessarily is a complementing activity to milk production. Poultry meat production has been a strongly centralized and in 13 years there has also been a threefold increase in production.

The production of sheep and lamb has remained stable but it's also faced a strong structural change.

Organic farming in Norway has remained stable at $2-3 \%$ of the area, although the goal was $15 \%$.

The area where grain is cultivated in Norway is decreasing. While there was an increase of $21 \%$ in the period between 1975 (Parliamentary decisions) and 1991, there has been a corresponding reduction between 1991 and 2012 to 76,300 hectares. This means that the imports of grains have increased and was in 2013/2014 at 1,400,000 million tons annually.

Concentrated feed imports increased by $81 \%$ from 2000 to 2012 . During the same period, productivity growth has been $60 \%$ and the real debt growth among Norwegian farmers 53\%.

All branches of production have had a decline in terms of price to the farmer, using 2012 values. The greatest declines have been for grains for human consumption, pork and poultry meat by over $50 \%$ and least for milk.

In the period 2000-2012 food prices have increased by $16 \%$, consumer prices by $26 \%$ while the increase in wages has been $72 \%$. This means that Norwegian consumers spend about $11 \%$ of their income on food, despite high food prices. 
In contrast, the production of local food has significantly increased. This must, however be seen in the light of the fact that in the beginning of 2000 there was approximately zero production of local food. Still, this maybe called a counter current in Norwegian food and agricultural policy, based on a growing demand for traditional local food, the desire for traceability and food safety, and of course the fact that Norwegians have a strong economy (Resultatkontrollen april 2013, Harstad og Lie (2013).

\section{Imports/exports}

Pursuant to the Norwegian Directorate of Agriculture imports of animal feed was 651,000 tonnes in 2014. In addition, there are imports of feed to fish (both of animal and plant origin) amounting to 1,450,000 tonnes.

Although Norway is self-sufficient in nitrogen fertilisers, other inputs - mainly potassium and phosphorus - are imported.

Norway currently has a self-sufficiency rate of about 35\% when taking into account imports of animal feed. Other imports mainly consist of beef -356.9 million $\mathrm{kg}$ in 2013. For dairy products there is significant imports of cheese, but Norway also export some. Other products that are imported are fruits, berries and vegetables. Norway exports a lot of fish and Pelagic fish (wild) is a net export product. The import-export balance for farmed fish varies; some years Norway has been an export country other years an import country.

\section{Jobs/employment}

Statistics for 2013 show that about $2 \%$ of the Norwegian workforce is directly employed in agriculture, of which $54 \%$ are over 50 years. Although the largest farms have the largest proportion of income from the farm, the majority of them will also have incomes from outside the farm (snow ploughing, lumberjack, part-time teacher or nurse etc.). Part-time farms in Norway are a prerequisite to maintain a desired settlement pattern, maintaining food production through the use of local and renewable resources, the cultural landscape and well tended villages and the creation of values that characterises rural Norway. Norway has introduced a support scheme for younger farmers. 


\section{Agricultural emissions of greenhouse gases - over 20 years}

The agricultural sector accounts for a significant share of Norway's emissions of greenhouse gases (nitrous oxide, methane and carbon dioxide) and other air pollutants, especially ammonia. Agriculture is the largest source of ammonia emissions, which together with NOx emissions contributes to eutrophication, but also to acidification.

Of the greenhouse gas emissions that Norway report to the UNFCCC approximately $8 \%$ is reported under the agricultural sector. There are also emissions from production of fertilisers, heating of buildings and fuel for driving agricultural machinery that are reported as emissions from energy production or industry but also being linked to the agricultural sector. In addition there are emissions from the production and transportation of imported inputs as fertiliser and feed. The most important sources were:

- Methane from enteric fermentation $\left(2,428\right.$ thousand tonnes $\left.\mathrm{CO}_{2} \mathrm{eq}\right)$.

- Nitrous oxide from nitrogen in soil (2,009 thousand tons $\left.\mathrm{CO}_{2} \mathrm{eq}\right)$.

- Carbon dioxide from organic soil (1,750 thousand tonnes of $\left.\mathrm{CO}_{2}\right)$.

- Mineral fertilizer production (612 thousand tons $\mathrm{CO}_{2}$ eq from $\mathrm{NO} 2$ and $\mathrm{CO}_{2}$ ).

- Methane and nitrous oxide from manure (storage and spreading) $\left(460,000\right.$ tonCO $\left.{ }_{2} \mathrm{ekv}\right)$.

- Carbon dioxide from fossil fuels (370 thousand tons of $\mathrm{CO}_{2}$ ).

\section{Nitrous Oxide}

In 2012 the emissions of nitrous oxide from agriculture were 7.4 thousand tonnes, equivalent to 2.2 million tonnes of carbon dioxide equivalents. This corresponds to about $4 \%$ of total greenhouse gas emissions. The emissions have been on an equal level since 1990.

Nitrous oxide emissions from agricultural soils represent $65 \%$ of the total nitrous oxide emissions in Norway. These emissions have been rather stable, since 1990 there has only been a $10 \%$ decrease.

Nitrous oxide is also formed through the handling and spreading of manure, representing up to $14 \%$ of all Norwegian nitrous oxide emissions. Again only a small decrease has been observed of these emissions since 1990. 
Norway also has 2 plants that produce nitrogen fertilizers, which caused nitrogen emissions of 0.9 tonnes in 2012. Though only 14\% of the fertilizers are being used by the Norwegian agriculture, the rest is exported. There has been a sharp decrease in emissions during the last decade as a result of improvements in the production process.

Similar changes were seen in the 1990's but these improvements were neutralized through and increased production.

The remaining emissions from nitrous oxide derive from the energy and transport sectors as well as from wastewater treatment plants.

Figure 1: Nitrous oxide emissions in Norway in 1000 tons between 1990 and 2012

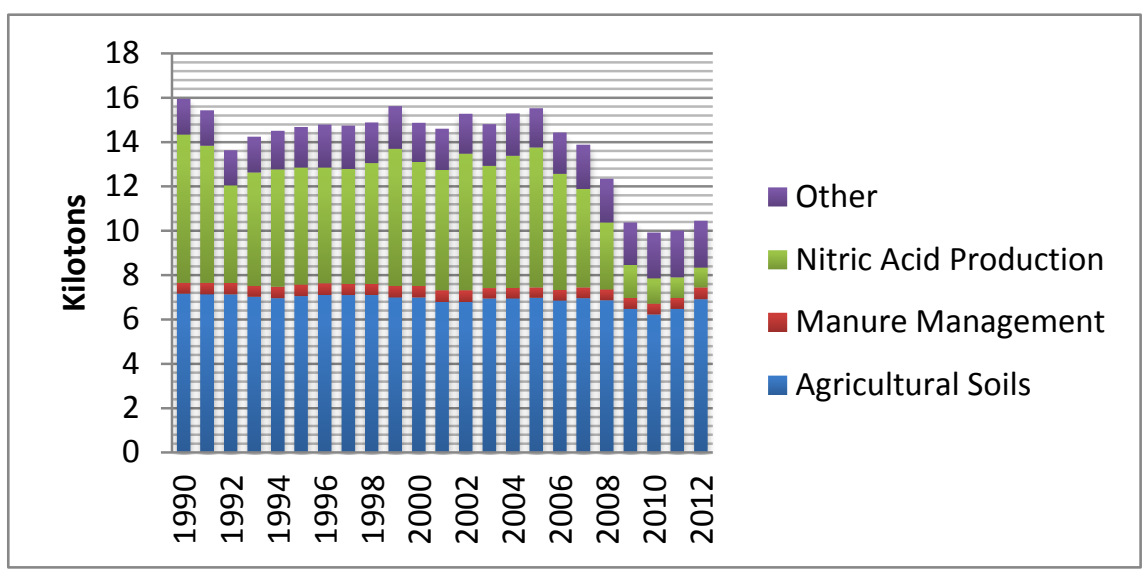

\section{Methane}

In 2012 methane emissions from agriculture were 106 thousand tonnes, equivalent to 2.7 million tonnes of carbon dioxide. This is roughly half of all methane emissions in Norway and 5\% of all greenhouse gas emissions (see figure 2). A predominant share of these agricultural emissions - some $46 \%$ - is from ruminants, where the gas is naturally produced from their digestion. However, these emissions have seen a reduction of $11 \%$ from 1990. Methane is also produced where manure decomposes anaerobically, representing some $7 \%$ of the total methane emissions. These emissions have been steady since 1990. 
Figure 2: Methane emissions in Norway in 1000 tons between 1990 and 2012

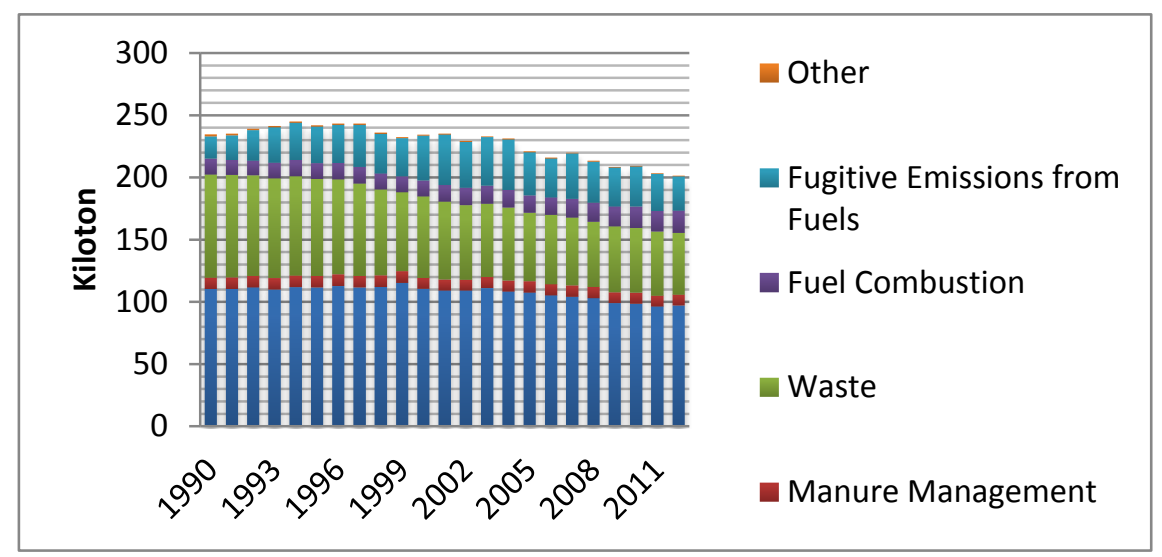

\section{Carbon dioxide from fossil fuels}

The agricultural sector emits carbon dioxide through energy production and transports. These emissions are reported to the United Nations, however not under the agricultural sector but under the energy and transport sector. In the national reports to the United Nations Panel on Climate the emissions of fossil fuels in the sectors for fisheries, agriculture and forestry was stated to be 2087 thousands of tonnes in 2012 . However both fisheries and forestry are significant sectors besides agriculture, probably contributing to a major part of the emissions.

In a government report on climate and agriculture from 2009 the emissions from the use of petrol and diesel fuels in the agricultural sector is estimated to 370 thousands of ton of carbon dioxide per year (Landbruks- og matdepartementet, 2009).

\section{Carbon dioxide from LULUCF (land use)}

In 2012 the net emissions from arable land were 1.8 million tonnes of $\mathrm{CO}_{2}$ and from grasslands 0.3 million tonnes of $\mathrm{CO}_{2}$. Most of these emissions come from organic soils, which form $8-9 \%$ of the total area cultivated. This is land that was previously underwater and is rich in organic matter that breaks down when it comes in contact with oxygen.

The $\mathrm{CO}_{2}$ emissions from land use change were only minor. Nearly all of the land that was cultivated in 1990 was still farmland in 2011. The largest change since 1990 was that parts of the land had been converted to settlements, and in the same period some forest was converted to agricultural land, the second change corresponds to the largest share of carbon dioxide emissions. The total cultivated area decreased by $1 \%$ over this period. 
Regarding grasslands, the land use change was somewhat larger, but still relatively small. Out of all grasslands that were not ploughed in 1990, 89\% was used for the same purposes in 2011. In some of these grasslands, the area has been vegetated with forest or converted to settlement. At the same time some forest areas have been converted to grasslands. All in all the total area of grasslands saw a decrease of $2 \%$.

The total carbon dioxide emissions for land that was converted to agricultural land amounted to 310 thousand tons a year in 2011 (Climate and Pollution Agency, 2013).

Figure 3: Land-use emissions in Norway in 1000 tons between 1990 and 2012

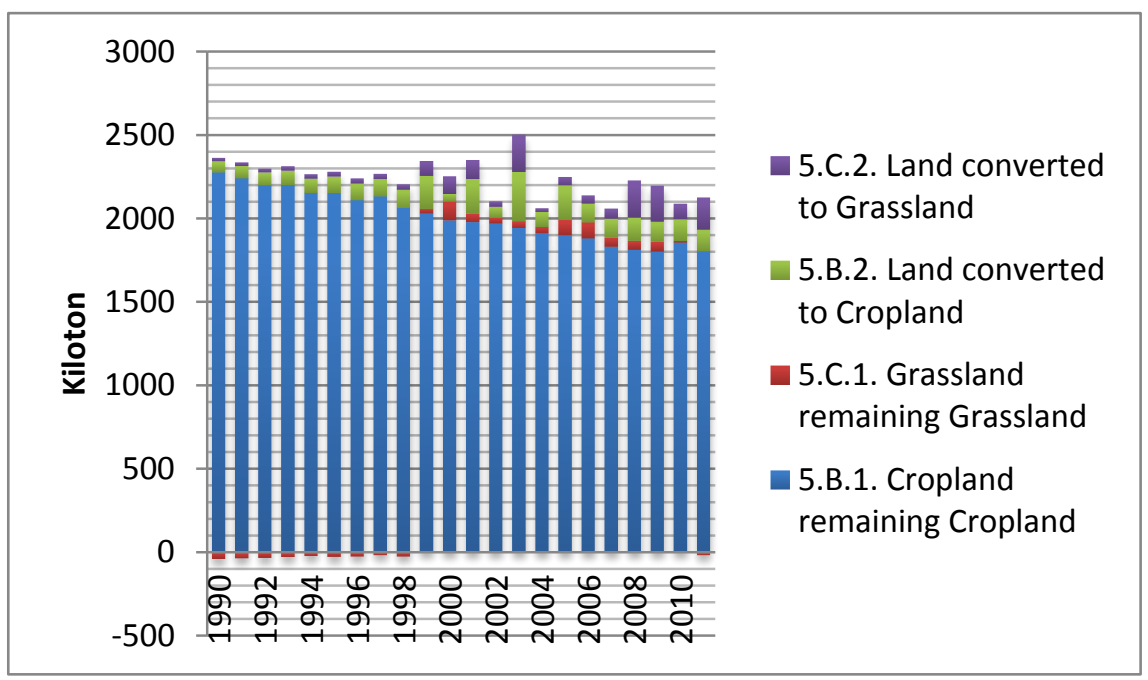

\section{Ammonia}

Ammonia emissions from agriculture were in 201224.7 thousand tonnes corresponding to $92 \%$ of all ammonia emissions (see figure 4). Manure is the culprit of more than $90 \%$ of the total ammonia emissions from the agricultural sector, only a smaller part origin from mineral fertilizers.

In Norway the total emission of ammonia from agriculture increased by $7 \%$ between 1990 and 2008, largely due to the increased use of mineral fertilizers and increased emissions from all categories of manure, except dairy cattle. Since 2008 the emissions has decreased somewhat.

Pursuant to Norway's commitments under the Gothenburg Protocol the ammonia emissions should not have been more than 23 thousand for 2010, however this emissions ceiling was exceeded by $16 \%$. In the revised Gothenburg Protocol from 2012, Norway furthermore committed to, by 
year 2020, decrease the ammonia emissions by $8 \%$ compared to the reference year of 2005. It is in fact a more lax target than before, corresponding to approximately 25,000 tonnes (Miljødirektoratet, 2015).

Figure 4: Ammonia emissions in Norway between 1990 and 2012

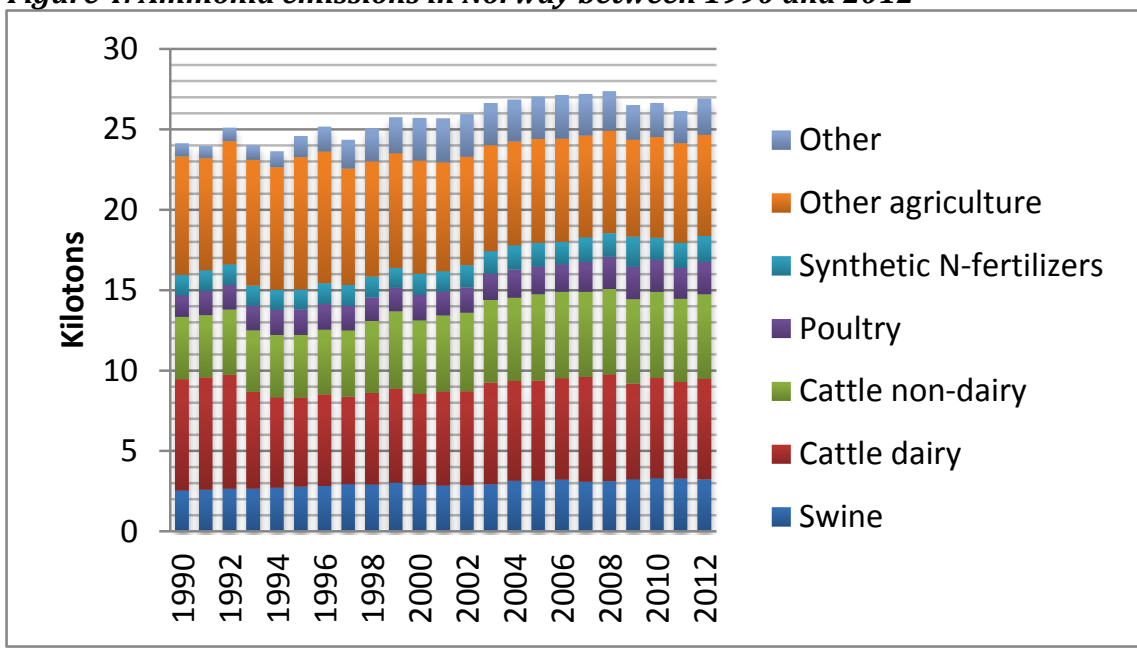

\section{Actions/Controllers}

\section{Support systems}

Grants are given to for spreading methods that incorporate manure faster into the soil (table 1). Such methods help reduce loss of ammonia to the air.

Table 1: Preliminary contribution rates

Direct injection in emerging culture

$80 \mathrm{NOK} / \mathrm{ha}$

Closures in open fields/stub + incorporation within 2 hours $\quad 50$ NOK/ha

Spread the incorporation within 2 hours $\quad 50$ NOK/ha

Additional hose in combination with the methods mentioned above

$35 \mathrm{NOK} / \mathrm{ha}$ 


\section{Rules for manure management}

There are several regulations for storage and spreading of manure (see table 2).

\begin{tabular}{|c|c|}
\hline Regulations & Norway \\
\hline $\begin{array}{l}\text { Controls on how and } \\
\text { when manure spreading } \\
\text { is allowed }\end{array}$ & $\begin{array}{l}\text { Ban on spreading manure on frozen ground or snow. } \\
\text { Dung should not be spread during the period } 1 \text { November to } 15 \text { February. } \\
\text { Manure application should mainly occur under growing season, i.e. from spring } \\
\text { to September } 1 \text { st. After this date all manure should be incorporated into the soil. }\end{array}$ \\
\hline $\begin{array}{l}\text { Requirements for storage } \\
\text { and use }\end{array}$ & $\begin{array}{l}\text { Each farm must have adequate area to spread the manure on (although no } \\
\text { requirements regarding allowed distance from the manure storage to the area) } \\
\text { All farms must have storage capacity for } 8 \text { months. }\end{array}$ \\
\hline Other requirements & $\begin{array}{l}\text { Construction for livestock and storage of manure/sewage sludge must not be } \\
\text { placed on flood-prone areas or as close to waterways, wells or other water } \\
\text { supply systems that creates the risk of contamination. } \\
\text { When placing the fur construction and start-ups of husdyrrom/fertilizer plants } \\
\text { must be given to the topography, vegetation and wind direction is such that the } \\
\text { placement does not result in odour problems. } \\
\text { Storage of manure shall be of sufficient capacity so that the manure can be } \\
\text { stored until the spread of the permitted period. The store must also have the } \\
\text { capacity to store any fertilizers that may be left in the warehouse after the last } \\
\text { delivery. Storage capacity shall be minimum } 8 \text { months production. } \\
\text { In new construction, expansion and renovation of storage for manure munici- } \\
\text { pality shall approve the plan before work can be performed. The store can not } \\
\text { be used until it has been inspected and approved by the municipality. The } \\
\text { Company shall regularly verify that the system works as intended and is } \\
\text { impervious to leakage. }\end{array}$ \\
\hline
\end{tabular}

\section{Tables and figures}

Table 1: Preliminary contribution rates.

Table 2: Rules for manure management.

Figure 1 Nitrous oxide emissions in Norway in 1000 tons between 1990 and 2012.

Figure 2 Methane emissions in Norway in 1000 tons between 1990 and 2012.

Figure 3 Land-use emissions in Norway in 1000 tons between 1990 and 2012.

Figure 4 Ammonia emissions in Norway between 1990 and 2012. 


\section{Annex 3: National Report: Agriculture in Sweden}

Project: "Pathways to a Nordic food system that contributes to reduced emissions of greenhouse gases and air pollutants".

\section{Introduction}

This national report constitutes an output under the project "Pathways to a Nordic food system that contributes to reduced emissions of greenhouse gases and air pollutants". This project is financed by the Nordic Minister Council and commenced in 2013. This report constitutes an annex to the comprehensive Nordic report: "Nordic agriculture air and climate - Baseline and system analysis report" and much of the data for Sweden was extracted from this national report. The national report mainly focuses on the national agricultural structures, land area use, agricultural production and current and projected greenhouse gas and ammonia emissions.

The main authors of this report are Kajsa Lindqvist and Miriam Márkus-Johansson.

\section{A brief description of the agricultural sector - 30 years back}

\section{Area}

Sweden has approximately 3 million hectares of agricultural land, which is about $7 \%$ of the country's total area. There are major differences between north and south. Approximately $60 \%$ of all agricultural land is found in the Götaland and Svealand plains. The country has 71,000 farms, averaging 37 hectares of land each. 


\section{Production and structural development}

The most common land use is ley farming and growing other forage, which took place on $38 \%$ of all agricultural land in 2012. The proportion of ley farming increases the further north you go in the country. In the most northerly counties, it is almost the only form of cultivation. The next most common crop is grain, which was grown on 33\% of the area. Other agricultural crops, especially oilseeds, pulses, potatoes and sugar beets were grown on $9 \%$ of the land. Permanent grasslands represent only $14 \%$ of the agricultural area. The remaining 5\% lay fallow. Approximately $14 \%$ of all agricultural land is used for organic farming.

There are approximately 1.5 million cattle in Sweden, of which a little less than a quarter being dairy cows. Almost a third of the cattle are found in two provinces, Skåne and Västra Götaland.

The number of pigs is about the same, though the geographical concentration is even greater. About a third of the animals are found in Skåne and only a small fraction of pigs are found north of Stockholm.

There are fewer sheep (including lambs), approximately 600,000, which are relatively evenly distributed across the country.

The population of hens and chicks is just over eight million, of which approximately 1.5 million are used for egg production. The vast majority are in the southern third of the country.

The production of beef and pork has decreased in the past two decades, while there has been a great increase in the production of poultry meat. Production of lamb meat has also increased, but is still quite marginal in quantity compared to the other types of meat. Dairy production has decreased, while egg production remains quite stable.

The general trend in livestock production is shifting towards fewer and larger herds. For example, there were 190,800 farms with cattle in 1961. The number of farms with cattle decreased to 19,600 in 2012. At the same time, the average herd size has increased from 12-77 animals.

The farms are usually specialized. A little less than one-third receives their main income from crop production and about the same proportion focus on animal husbandry. Only $7 \%$ have a relatively even distribution of income from both livestock and crop production.

\section{Employment, demography and spending}

Agriculture employs less than $2 \%$ of the labour force in Sweden. Almost $70 \%$ of the aging Swedish farmers are more than 50 years old. Many (35\%) of the farms require so few working hours that they are judged not to be a main source of income for their owners. Less than a quarter 
of all agricultural deemed equivalent to a full-time job or more and only a few thousand deemed to be so large that they have employees. The Swedish government has also established an incentive scheme to make farming more attractive for young farmers.

Many farms, around 35\%, were considered smallholdings. In other words they require so few hours that they are assumed not to be a main source of income for their owners. Less than a quarter of all farm businesses are assumed to be equivalent to a full-time job or more. Many farms also have significant income from forests. Only 5,000 of the farms are assumed to be so large that they have employees (The Swedish Board of Agriculture and Statistics Sweden, 2013).

\section{Agricultural emissions of greenhouse gases and ammonia - now and 20 years back}

\section{Domestic emissions}

The agricultural sector also accounts for a significant proportion of Sweden's emissions of greenhouse gases (nitrous oxide, methane and carbon dioxide) and other air pollutants, especially ammonia.

Of the Swedish greenhouse gas emissions that were reported to the UNFCCC for 2012 (a total of 57.6 million tonnes $\mathrm{CO}_{2} \mathrm{eq}$ ), ${ }^{1} 7.7$ million tonnes of $\mathrm{CO}_{2} \mathrm{eq}$ were reported under the heading of agriculture and accounted for about $13 \%$ of total greenhouse gas emissions. In addition, some emissions from combustion of fossil fuels in the sector are reported under the heading of energy and emissions or sequestration of carbon in soil, which are reported under land use. If emissions from energy use are included, the share rises to $15 \%$. LULUCF emissions were about 2.3 million tonnes.

If you want to assess the full climate impact of Swedish agriculture you should also count emissions that occur in other countries from the production and transportation of imported inputs such as fertilizer and feed.

In total this amounts to just over 12 million tonnes of $\mathrm{CO}_{2}$ eq distributed between the following sources:

- Nitrous oxide from nitrogen in soil (4.40 million tonnes).

- Methane from enteric fermentation (2.54 million tonnes). 
- Carbon dioxide from processed organogenic soil (2.29 million tonnes).

- Carbon dioxide from fossil fuels (1.22 million tonnes).

- Methane and nitrous oxide from manure (storage and distribution) (0.75 million tonnes).

- Manufacture of used mineral fertilizers (0.68 million tonnes).

- Imported feed (0.28 million tonnes).

Source: European Environmental Agency (a), the Swedish Board of Agriculture 2012.

Ammonia emissions from agriculture amounted to 44.0 thousand tonnes in 2012, which corresponds to $85 \%$ of all ammonia emissions. Most of it is from emitted from manure in stalls, during manure storage and spreading. Ammonia losses also occur from manure from grazing animals and a small part of ammonia emissions from the spreading of mineral fertilizer (European Environmental Agency (b)).

\section{Nitrous oxide}

Nitrous oxide is produced when microorganisms break down and convert various compounds containing nitrogen. The amount of nitrogen in the soil increases when manure or mineral fertilizer is added, or when nitrogen-fixing plants are grown. This also increases the risk of formation of nitrous oxide. Farmlands that are naturally rich in nitrogen, mostly land with a high share of organic matter (known as organogenic soils), can be significant sources of nitrous oxide whether extra nitrogen is added via nitrogen fertilization or not. Similarly nitrous oxide is formed and emitted when handling and spreading manure.

In 2012, nitrous oxide emissions from agriculture in Sweden totalled 16 thousand tonnes, which is 4.8 million tonnes of carbon dioxide equivalents. This means that nitrous oxide from agriculture represents $9 \%$ of the total greenhouse gas emissions in Sweden.

Emissions have decreased by $17 \%$ since 1990 (Figure 1). This is due to both improved manure management and lower loads of nitrogen on arable land.

Production of nitric acid used for mineral fertilizers is an additional source of nitrous oxide emissions. Swedish production is located at a single plant in Köping. However in the UNFCCC reports these emissions are counted as industrial. It is worth noting that Sweden also imports a lot of fertilizer. In recent years, domestic emissions from fertilizer production have been reduced significantly due to improved technology. 
Figure 1: Nitrous oxide emissions in Sweden in 1000 tonnes between 1990 and 2012

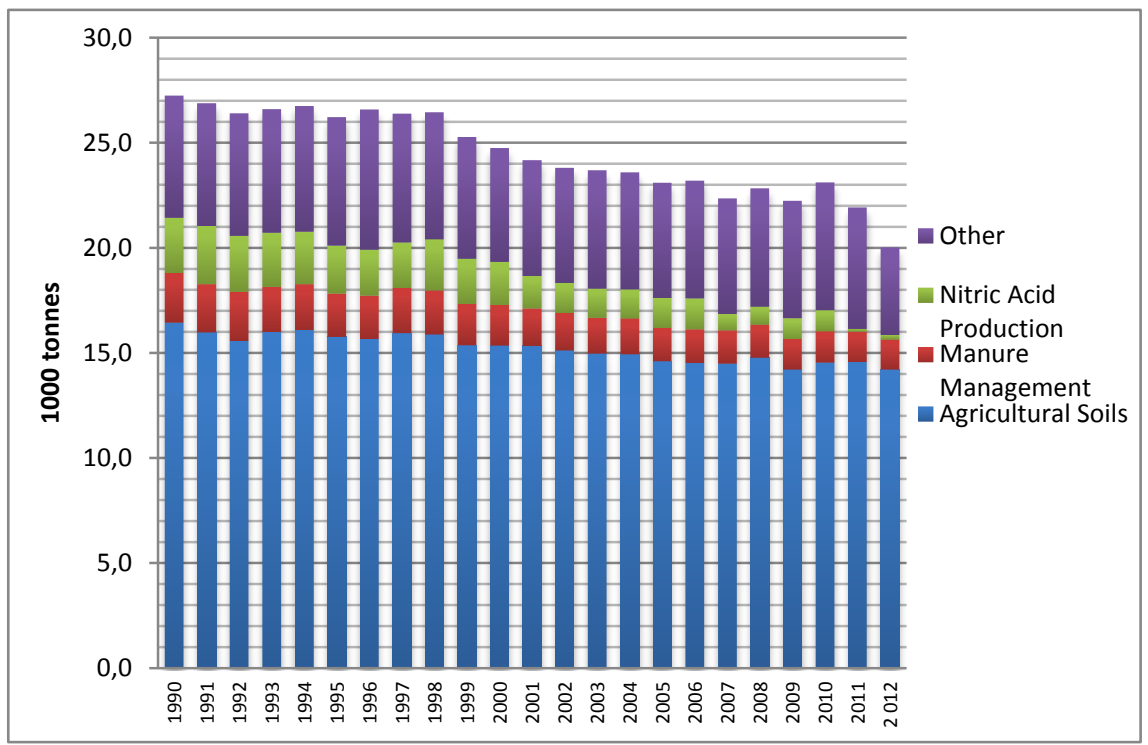

Source: European Environmental Agency (a).

\section{Methane}

Most of the methane emissions in agriculture come from ruminants. The gas is formed naturally during their digestive process. Methane can also be formed when manure is broken down anaerobically.

In 2012 methane emissions from agriculture were around 136 thousand tonnes, equivalent to 3.4 million tonnes carbon dioxide. This is about $60 \%$ of all methane emissions and $6 \%$ of the total greenhouse gas emissions.

Between 1990 and 2012, methane emissions from agriculture decreased by $10 \%$ (Figure 2). The number of cattle in the same period fell by $12 \%$, which can almost entirely explain the reduction. However, part of the reduction was offset by emissions from manure that increased by nearly $30 \%$ over the same period. This is mainly due to the transition from solid manure systems to slurry systems, a change that leads to increased methane emissions, but to lower nitrous oxide emissions. 


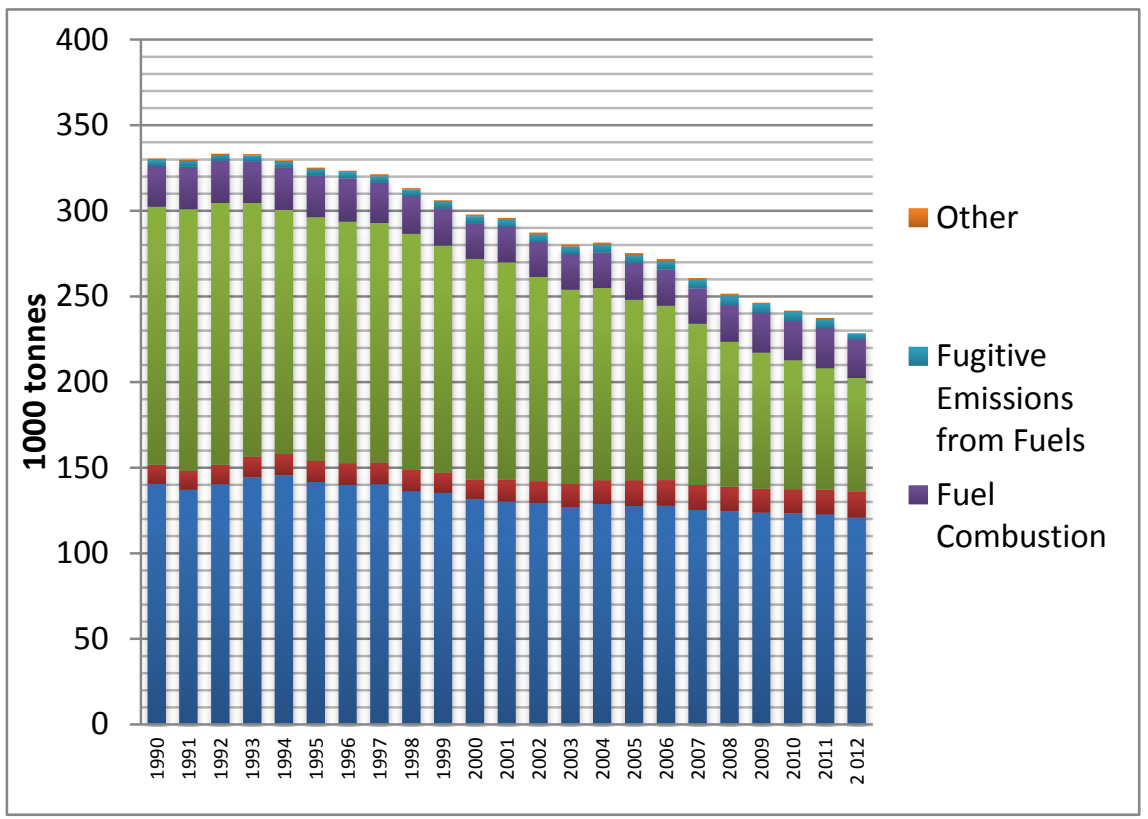

Source: European Environmental Agency (a).

\section{Carbon dioxide from LULUCF}

Reduced carbon in agricultural soils also leads to carbon emissions, while on the other hand if carbon stocks increase, farmland will act as a sink for carbon dioxide.

More than 5\% of Swedish agricultural land consists of organogenic soils, i.e. peat and mud soils. Carbon dioxide leakage from these soils is 200 to 500 times higher per hectare than for agricultural land on mineral soils. Total estimated carbon emissions from organic farmland and cropland on mineral soils were 1.8 million tonnes in 2010. However, there is a large variation from year to year. Between 1990 and 2010, this figure has fluctuated between 1.4 and 2.7 million tonnes of carbon dioxide. This is mainly because there are large uncertainties in measuring small variations in emissions from such a large stock. Pastures are instead estimated to bind 0.6-0.9 million tonnes of carbon dioxide per hectare per year and thus act as a sink (The Swedish Board of Agriculture, 2012 (a), page 6).

Total estimated carbon emissions from agricultural land were 2.3 million tonnes of $\mathrm{CO}_{2}$ in 2012. 


\section{Carbon dioxide from energy and transport}

Agriculture emits carbon dioxide to meet its requirements for energy and transport. These emissions are shown in the reporting to the UNFCCC under the heading of energy. Stationary energy accounted for about 0.4 million tonnes in 2010 (of which $40 \%$ came from greenhouse cultivation). Fuel use for machinery was estimated at 0.82 million tonnes of carbon dioxide in the same year (The Swedish Board of Agriculture, 2012, p. 5).

\section{Ammonia}

Ammonia is released mainly from manure in stalls, during storage and when it is spread on fields. A small portion is also emitted from mineral fertilizer.

In 2011, emissions of ammonia in Sweden totalled 52,000 tonnes, of which 44,000 tonnes came from agriculture, which is about $85 \%$ of total emissions.

Of ammonia emissions from agriculture, more than 95\% comes from manure, with manure from cattle representing the largest share. Of the total amount of nitrogen in manure, approximately $30 \%$ is lost as ammonia leakage (Official Statistics of Sweden, 2014).

Since 1995, agricultural emissions of ammonia have decreased by $25 \%$ (Figure 3). This can mostly be explained by reduced livestock numbers, but also by improved manure management (The Swedish Environmental Protection Agency, 2014).

Figure 3: Ammonia emissions in Sweden between 1990 and 2012

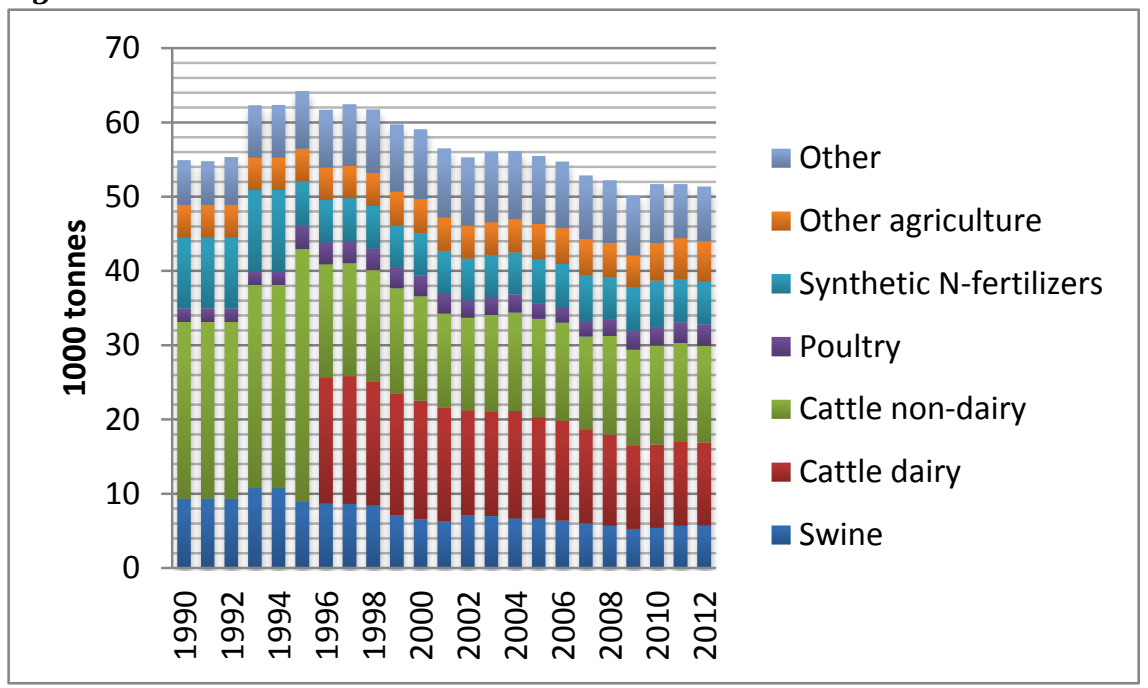

Source: European Environmental Agency (b). 


\section{Indirect emissions}

The production of imported inputs such as feed and fertilizer leads to emissions in the countries where they have been manufactured and are not included when Sweden reports to the UNFCCC.

The Swedish Board of Agriculture estimates that the 650 thousand tonnes of feed that is imported causes emissions of approximately 0.28 million tonnes of $\mathrm{CO}_{2}$ equivalents per year during cultivation, processes and transportation (excluding land use change). (The Swedish Board of Agriculture, 2012). If we also take into account changes in land use for imported soy, emissions are instead in the region of 0.5 to 1 million tonnes of $\mathrm{CO}_{2}$ equivalents depending on the calculation method used.

Just over 161 thousand tons of mineral fertilizers were sold in $2012 / 2013$. Their production causes emissions of nitrous oxide as well as emissions from the energy used in the process. The Swedish Board of Agriculture estimates that about three-quarters of the mineral fertilizers used in Sweden are manufactured in Western Europe, with an emission factor of $3 \mathrm{~kg} \mathrm{CO}_{2}$ eq per $\mathrm{kg} \mathrm{N}$, while the remaining mineral fertilizer is produced in Russia, with an emission factor of $8 \mathrm{~kg} \mathrm{CO}_{2} \mathrm{eq}$ per $\mathrm{kg} \mathrm{N}$. This means that the total emissions from nitrogen fertilizer are 0.68 million tonnes.

Swedish consumption of imported foods similarly causes emissions abroad. There is a great risk that measures intended to reduce domestic production, actually reduce emissions in Sweden, but also lead to increased imports and thus emissions elsewhere.

The Environment Protection Agency has estimated that about $60 \%$ of the greenhouse gas emissions caused by Swedish consumption take place overseas. Based on imports of eggs, meat and milk in 2005, the Board of Agriculture estimated that the emissions from Swedish food consumption are in the region of three million tonnes of $\mathrm{CO}_{2}$ eq per year (emissions from land use change are not included) (The Swedish Board of Agriculture 2012 (a)).

In most categories of agricultural products Sweden is a net importer (Figure 4). Above all, we can see an increase in net imports of meat, dairy and eggs over the past decade. These are all food categories with high emissions of both airborne pollutants and greenhouse gases. The exceptions are cereals and tobacco. The latter may seem strange given that the cultivation of tobacco in Sweden is not particularly extensive. This is because Sweden imports cheap raw tobacco, which is processed and then exported with a higher value. 
Figure 4: Net exports of agricultural goods in USD in 2003 and 2012

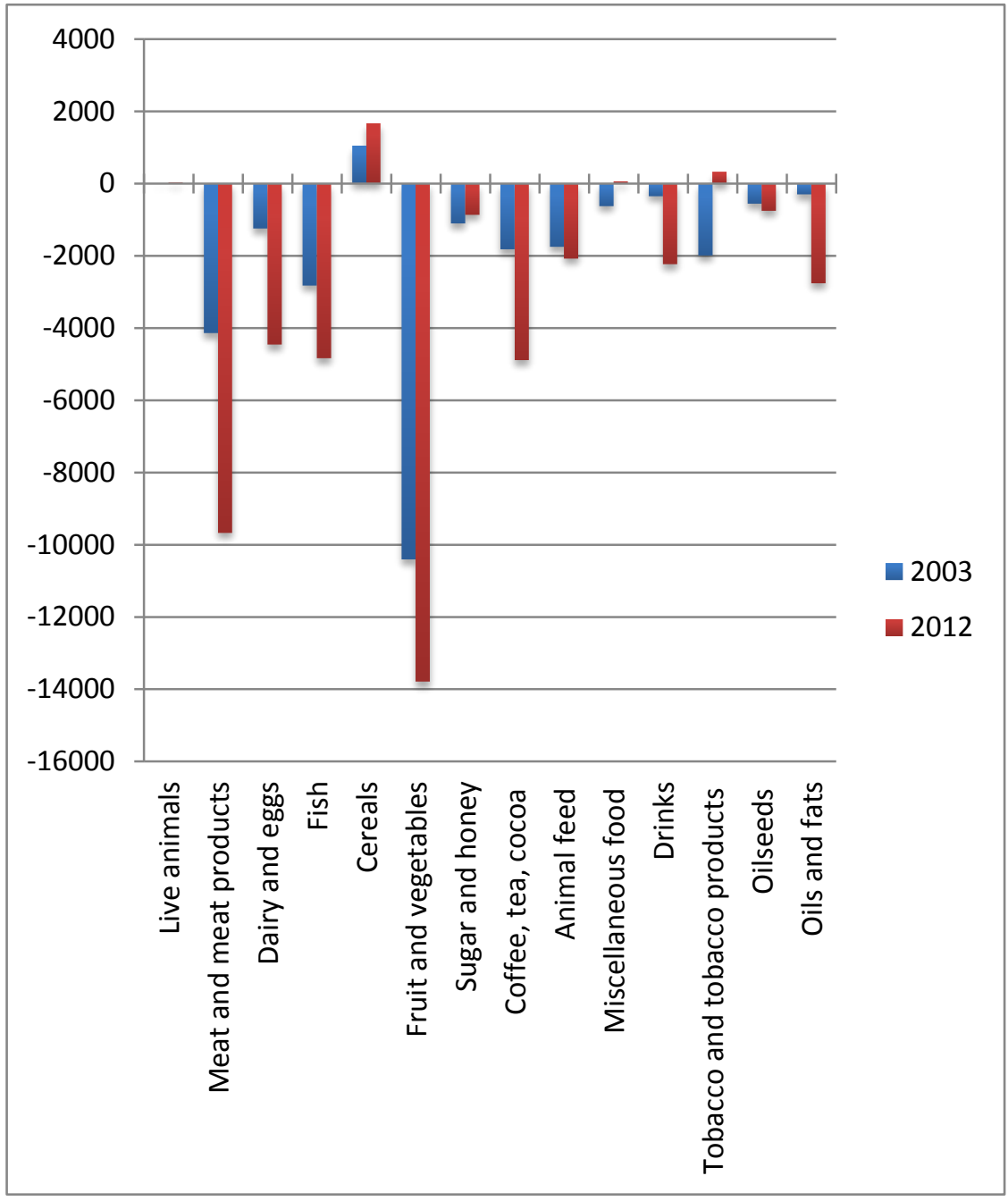

Source: The Swedish Board of Agriculture 2012 (b), The Swedish Board of Agriculture 2013 (b).

\section{Future emissions of greenhouse gases}

The Board of Agriculture has on behalf of the Environmental Protection Agency developed a reference scenario for agricultural emissions of greenhouse gases by 2050. The scenario is based on the assumption that Sweden will produce just as much in the future as today, but that productivity increases by $0.5 \%$ each year. That is, the same amount of products will be produced in a smaller area and with fewer inputs. The assumed efficiency improvements would reduce emissions of methane and nitrous oxide by $8 \%$ between 2010 and 2050 . This is a slower rate 
of decline than we have seen in the past decade, which has mainly been caused by the reduced number of animals and reduced production (The Swedish Board of Agriculture, 2012 (a)).

The report points out that it is difficult to predict how large domestic production will be by 2050 . It might well continue to decline according to the current trend, or increase due to changes in world prices and the food needs of a large domestic population.

For ammonia, the Board of Agriculture has developed a reference scenario for 2030, which also assumes sustained production. It shows only marginal reductions. Between 2009 and 2030, the reduction in emissions will be less than 3\% (The Swedish Board of Agriculture, 2013).

\section{Actions/Controllers}

The report lists state, local and private initiatives that were either directly aimed at reducing greenhouse gases and air pollutants, or had another primary goal that would also achieve emission reductions.

\section{Support systems}

Among the measures that could provide environmental support under the Rural Development Programme (2007-2013), several have effects on emissions (Table 1).

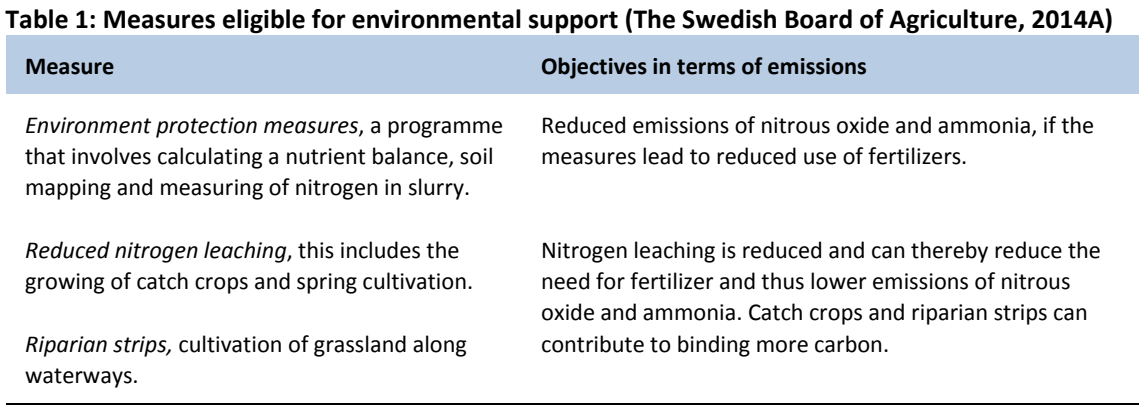

In the summer and autumn of 2014 the EU Commission processes a new draft Rural Development Programme for the period up to 2020. The environment protection measures will disappear, while the other two measures remain (The Swedish Board of Agriculture, 2014b).

The bulk of agricultural support is channelled through the single farm payment scheme. Until 2014 this was not subject to any environmental requirements apart from cross-compliance, which basically means that 
farms must comply with current environmental laws in order to qualify for the payment. From 2014, farms must meet 3 very basic environmental requirements. One of them is the requirement not to plough or convert grasslands in Natura 2000 and other designated areas, which may have an impact on carbon sequestration.

Until 2005 direct payments were related to the number of animal units on a farm. This created an incentive to rear more animals. This was an incentive that disappeared when subsidies were decoupled. In most parts of Europe, the number of animals decreased and thus also emissions.

\section{Rules for manure management}

All livestock farms must have sufficient manure storage in order to avoid spreading manure during inappropriate times of the year. The number of animals and the location of the farm determine the size. In southern Sweden there are also requirements for coverage of slurry and urine tanks, with a floating cover or equivalent. There are also geographically specific rules for when you can spread the manure and how quickly it should be incorporated into the soil (The Swedish Board of Agriculture 2014c).

So-called sensitive areas, e.g. areas near the coast south of Stockholm, are subject to additional rules. In these areas it is not permitted to spread more manure than the equivalent of $170 \mathrm{~kg}$ of nitrogen per hectare and year. For winter oilseed crops (that are sown during the autumn) there is a maximum load of $60 \mathrm{~kg}$ of nitrogen per hectare. For other winter crops there is a maximum load of $40 \mathrm{~kg}$ of nitrogen.

In sensitive areas in the country's most southerly parts, there are also restrictions on which spreading techniques may be used (The Swedish Board of Agriculture, 2014c).

\section{Other laws and directives}

\section{Tax on fertilizers}

Between 1984 and 2010 there was a tax on fertilizer in Sweden. When it was abolished the rate was SEK 1.80 per kilogram of nitrogen. The tax also included a component for the cadmium content of the fertilizer.

The argument for abolishing the tax was that Swedish agricultural products were disadvantaged, since no other EU country had this kind of tax.

The Swedish Agricultural Board estimates that the abolished tax has led to increased nitrous oxide emissions equivalent to 0.07 million 
tonnes of $\mathrm{CO}_{2}$ equivalent per year (The Swedish Board of Agriculture, $2012(\mathrm{a}))$.

\section{The Nitrates Directive}

The aim of the Nitrates Directive introduced in 1991 is to protect surface and groundwater from high levels of nitrate. The measures resulting from the directive have led to more efficient nitrogen use in agriculture, which also has led to reduced nitrous oxide and ammonia emissions, although this was not the initial intention. In 2008 it was estimated that nitrous oxide emissions in Sweden were 5.8\% lower than they would be without the directive, whereas the effect of ammonia is estimated at $0.7 \%$ (Velthof et al. 2009).

\section{EU Directive on industrial emissions}

The Industrial Emissions Directive (2010/75/EU) requires licensing and the use of best available techniques for the establishment of pig farms with more than 2,000 fattening pigs or 750 sows, and poultry farms with more than 40,000 birds.

\section{Advice and counselling}

\section{Focus on Nutrients}

Focus on Nutrients ("Greppa Näringen" in Swedish) is a joint venture between the Swedish Board of Agriculture, the County Administrative Boards, the Federation of Swedish Farmers and a number of companies in the farming business. They offer free consultations so that farmers will be able to reduce their losses of nutrients and greenhouse gases. A total of 30,000 farm visits have so far been conducted. The project initially focused on reducing nitrogen and phosphorus losses, but since 2010 has focused on the climate aspects of the concept (Greppa Näringen, 2014).

\section{Changing consumption}

\section{Climate labelling}

Swedish Seal (a subsidiary of the Federation of Swedish Farmers) and KRAV (a body for labelling organic farming) developed a climate certification scheme for Swedish food between 2007 and 2012 in collaboration with a small number of food manufacturers. The label requirements include energy usage, nutrient balance and slaughter age. 
The largest reductions in per cent among those certified have been among greenhouse growers, while the reduction potential for a farm with cattle is much lower (Klimatmärkning, 2014).

\section{Dietary guidelines}

On 19 November 2013 the National Food Agency (NFA) presented its "environmentally smart" dietary guidelines:

- Eat less meat, choose vegetable options instead. Try to exchange one or two meals of beef, lamb, pork or chicken every week with vegetarian meals, or eat smaller portions of meat.

- Choose fish from sustainable stocks or farmed in a sustainable way, for example certified fish.

- Choose fruits and vegetables that store well, for example field vegetables, and choose perishable fruits and vegetables when they are in season.

- Eat less sweets, cakes, cookies and snacks - they have an impact on the environment but their nutritional contribution is low.

- Minimise food waste - store food properly, plan your purchases and use the leftovers! (The National Food Agency 2013).

The NFA had already drafted a set of guidelines in 2011, but they were stopped because the wording on locally produced food was regarded as setting up trade barriers by the EU Commission (Miljöaktuellt, 2013).

\section{School meals}

Many municipalities work to reduce the environmental impact of school meals. This is done by reducing the amount of meat, for example by reducing the meat content in Bolognese sauce, or by introducing more vegetarian food on the menu. The savings made on reduced meat purchases often enable more to be spent on organic food. 


\section{Tables and figures}

Figure 1: Nitrous oxide emissions in Sweden in 1000 tonnes between 1990 and 2012.

Figure 2: Methane emissions in Sweden in 1000 tonnes between 1990 and 2012.

Figure 3: Ammonia emissions in Sweden between 1990 and 2012.

Figure 4: Net exports of agricultural goods in USD in 2003 and 2012.

Table 1: Measures eligible for environmental support. 


\section{Annex 4: National Report: Agriculture in Finland}

Project: "Pathways to a Nordic food system that contributes to reduced emissions of greenhouse gases and air pollutants".

\section{Introduction}

This national report constitutes an output under the project "Pathways to a Nordic food system that contributes to reduced emissions of greenhouse gases and air pollutants". This project is financed by the Nordic Minister Council and commenced in 2013. This report is an annex to the comprehensive Nordic report and much of the data for Finland was extracted from this national report. This national report mainly focuses on the national agricultural structures, land area use, agricultural production and current and projected greenhouse gas and ammonia emissions.

The main authors of this report are Anne Antman and Jenny Teerikangas. Kajsa Lindqvist and Miriam Márkus-Johansson contributed to the finalisation of this report.

\section{A brief description of the agricultural sector - now and 30 years back}

\section{Area}

In Finland there is approximately 2.3 million hectares of agricultural land (Tike 2014b), which translates to about $9 \%$ of the land area (Statistikcentralen 2013a, p. 124). Over the past few decades, the agricultural land area has remained about the same. Some fields have been abandoned, but in parallel, new arable land has been cleared elsewhere (Regina et al. 2014, p. 14).

The share of agricultural land varies greatly by region. Most agricultural land is in southern and western Finland. In Varsinais-Suomi, agri- 
cultural land makes up 30\% of the land area, and in Uusimaa and Häme, over 20\% (Statistikcentralen 2013a, p. 125).

Today there are about 55,000 farms in Finland. The average acreage per farm is about 40 acres. (Tike nd (f)). In recent decades, the number of farms has decreased rapidly, while the average acreage per farm has increased.

In Finland the ownership structure is quite fragmented and the fields are scattered, which increases the need for transportations between the farms. There are large contiguous arable areas only in Southern Finland and Ostrobothnia along the rivers. Further north the average size of parcels is smaller and the distance between parcels increases.

\section{Production and structural development}

Cereals are grown on about half of the agricultural land and grassland represents a third. Eastern and northern Finland has the highest share of grassland, while the lowest is in western and southern Finland. Turnip rape, potato, sugar beet, peas and other non-grain crops are grown on a tenth of the agricultural land. Just over one-tenth of agricultural land lay fallow (Tike 2014b). Natural meadows and natural grasslands constitute less than $1 \%$ of the utilized agricultural area (Tike nd (e)).

On more than $60 \%$ of farms the main production is plant cultivation. Dairy farming is the main production on almost $16 \%$ of farms, beef production on almost $6 \%$ of farms, rearing pigs on nearly $2 \%$ and poultry production on less than $1 \%$ of farms. On over $6 \%$ of farms the main production is other grazing animals, such as sheep, goats or horses (Mills nd (b)).

Approximately $80 \%$ of the arable land is used to grow feed for livestock (Niemi et al. 2013, p. 31). Production from a tenth of arable land is used for vegetable products for human consumption (Tike 2014A).

The number of cattle has decreased by more than $30 \%$ between 1990 and 2011, from about 1.36 million individuals to approximately 0.91 million individuals (Tike nd (c)). In 2011, the total number of pigs was approximately 1.34 million, which was slightly lower than in 1990 when the total was around 1.38 million (Tike nd (d)). The total number of poultry in 1995 was about 10.36 million, and in 2011 around 10.24 million (Tike nd (a)). The majority of livestock feed is of domestic origin. About half of the domestic grain crop and forage production as a whole is used to feed livestock in Finland (Tike 2014A).

The number of livestock farms has decreased and the herds have become larger. In 2011 there were less than half as many farms with dairy farming and rearing pigs compared with the situation in 2000. The 
number of farms with poultry production had fallen by nearly half over the same period (Tike 2012, p. 48).

Livestock farms are concentrated in certain regions and crop production in other regions. The national agricultural subsidies have encouraged livestock farms to expand in the northern regions (support region C) (Ollikainen et al. 2014, p. 17). Today, $80 \%$ of all beef is produced in support region C and only $20 \%$ in the southern support areas A and B. Over half of the beef is produced in the three Ostrobothnian regions and in North Savo (Tike u.å. (g)). Pork is produced mostly in southwest Finland, Ostrobothnia and Southern Ostrobothnia (Tike u.å. (h)).

The geographical concentration of livestock farms also causes problems with manure spreading. Expanding livestock farms need more arable land on which to spread the manure they produce. In areas where there are limited opportunities to create new farmland, many farms instead clear forest for new fields.

In 2011, the domestic production of grains, pork, poultry meat, eggs and milk fats was $100 \%$ of domestic consumption. In the case of grains it varies in percentage from year to year depending on, among other things, the weather. Beef production was 83 of consumption and liquidbased dairy products amounted to $95 \%$ of consumption. The domestic production of sugar covered only $49 \%$ of domestic consumption (Statistikcentralen, 2012, p. 165).

\section{Imports/exports}

The production of imported agricultural products as feed for animals and food, are reported as emissions in the countries where they were cultivated, not in Finland.

In the case of staple foods, self-sufficiency in Finland is high. Selfsufficiency in the food market was 75\% in 2008 (Niemi et al. 2013, p. $35)$. However, the self-sufficiency decreased and the import of staple foods increased roughly by 5\% during 2003-2008 (Niemi et al. 2013, p. 35-36).

In recent years the import of meat has increased and the export of meat decreased, especially for pork, but also for beef and poultry. The total import of meat rose from 54.0 million kilograms in 2008 to 81.4 million kilograms in 2012. During the same time period the export of meat fell from 73.4 million kilograms in 2008 to 52.3 million kilograms in 2012.

Finland is self-sufficient in feed grains and exports oats and barley. Finland is not self-sufficient in oilseeds, which are used to produce edible oils and protein fodder (Niemi et al. 2013, p. 31). The shortfall is 
covered by imports, mainly of rapeseed, canola meal and soybean meal (Agriculture and Forestry 2010, Chapter 2.2.2.).

In 2009 the domestic feed processing industry used about 120 thousand tonnes of domestic turnip rape and rape, as well as 160 thousand tonnes of imported turnip rape and rape. This is made into oil, cracked kernels (rouhe) and expeller (puriste). The amount of oil produced was 100,000 tonnes, including 50,000 tonnes of oil used in domestic food and feed production. The rest of the oil is exported. The total amount of cracked kernels and expeller was 180 thousand tonnes, of which 10,000 tonnes of expeller went to export. To meet the demand for aggregates, about 130-170 thousand tonnes of soybean meal and about 95-115 thousand tonnes of cracked rapeseed are also imported annually. In 2009, roughly 154,000 tonnes of soybean meal was imported for animal feed use. (Jord- och skogsbruksministeriet 2010, Chapter 2.2.2.).

\begin{tabular}{|c|c|c|c|c|}
\hline Type of product: & $\begin{array}{r}\text { Exports, } \\
\text { tonnes }\end{array}$ & $\begin{array}{r}\text { Exports, } \\
\text { million EUR }\end{array}$ & $\begin{array}{r}\text { Imports, } \\
\text { tonnes }\end{array}$ & $\begin{array}{r}\text { Imports, } \\
\text { million EUR }\end{array}$ \\
\hline Meat and meat products & 67,154 & 121.4 & 64,219 & 278.7 \\
\hline Fish & 44,867 & 26.8 & 49,504 & 201.4 \\
\hline Dairy products & 203,161 & 450.4 & 158,875 & 304.5 \\
\hline Eggs & 11,252 & 11.2 & 1,862 & 2.9 \\
\hline Cereals & $1,005,395$ & 207.6 & 71,246 & 32.6 \\
\hline Vegetables & 41,181 & 18.1 & 170,791 & 201.7 \\
\hline Fruits and nuts & 10,739 & 30.7 & 292,820 & 345.4 \\
\hline Sugar, confection and honey & 74,396 & 80.9 & 244,473 & 165.5 \\
\hline Oils and fats & 46,398 & 63.7 & $\ldots$ & 282.1 \\
\hline $\begin{array}{l}\text { Feedstuffs for animals (not including } \\
\text { unmilled cereals) }\end{array}$ & 63,659 & 30.2 & 483,109 & 223.8 \\
\hline
\end{tabular}

(Tike 2012, pp. 184-187).

\section{Consumption patterns}

In recent decades, Finnish consumption of food has changed somewhat. The consumption of cereals has risen per person per year from $74.2 \mathrm{~kg}$ in 1990 to $78.8 \mathrm{~kg}$ in 2011. Consumption of meat in the same period increased from $67.0 \mathrm{~kg}$ per person per year to $77.6 \mathrm{~kg}$. Beef consumption has fallen by about $14 \%$, while consumption of pork increased by about $10 \%$ and consumption of poultry meat has increased by over $60 \%$. The consumption of liquid dairy products fell by more than a quarter between 1990 and 2011 (Tike, 2013). 


\section{Employment and demography}

The agricultural sector employed 3.1\% of labour force in Finland in 2012. In 2012 the statistical average age of a Finish farmer was 51. Since 1995, the average age has risen by about 3 years. The percentage of farmers over the age of 55 has increased from 26\% in 2001 to $39 \%$ in 2012. Also in Norway, the government has put into place an incentive scheme to support young farmers.

\section{Agricultural emissions - now and 20 years back}

\section{Greenhouse gas emissions}

Agriculture accounts for a significant share of Finland's greenhouse gas emissions (nitrous oxide $\mathrm{N}_{2} \mathrm{O}$, methane $\mathrm{CH}_{4}$, and carbon dioxide $\mathrm{CO}_{2}$ ) and other air pollutants, especially ammonia $\mathrm{NH}_{3}$. These emissions arise mostly because of biological processes that are difficult to control. A measure that is intended to reduce emissions of one gas can also lead to greater emissions of another gas. Calculations of the levels of emissions can also include some uncertainties.

Finland has ratified the UN Climate Convention (UNFCCC) and the Kyoto Protocol, and reports greenhouse gas emissions annually in accordance with UNFCCC guidelines. Emissions arising from agriculture are reported in several sectors. Methane and nitrous oxide emissions are reported for the agricultural sector, while carbon dioxide emissions arising from agriculture are reported within land use and energy sectors.

According to the climate and energy strategy, greenhouse gas emissions from the agricultural sector should decline by $13 \%$ by 2020 compared with the level in 2005 (Arbets- och näringsministeriet 2008, p. 84, table 8).

Total emissions from the agriculture sector in 2011 were about 5.9 million tonnes of carbon dioxide equivalents, which represents about 9\% of Finland's total greenhouse gas emissions. ${ }^{17}$ Carbon dioxide released from agricultural soils totalled 7.1 million tonnes of carbon diox-

\footnotetext{
17 Finland's total GHG emissions stood at 67.0 million tonnes of carbon dioxide equivalents in 2011. The land use sector (LULUCF) is not included in the total greenhouse gas figure, but it is reported separately. In 2011, the land use sector acted as a carbon sink of 24.6 million tonnes of carbon dioxide equivalents (Statistikcentralen 2013b, p.10).
} 
ide equivalents in 2011. Greenhouse gas emissions derived from energy consumption in the agricultural sector accounted for 1.3 million tonnes of carbon dioxide equivalents in 2011. Altogether, emissions originating from agriculture in Finland amounted to 14.3 million tonnes of carbon dioxide equivalents (Statistikcentralen 2013b, p. 30-32).

The digestive processes of ruminants and other livestock are a source of methane emissions. Methane and nitrous oxide arise in livestock housing and during manure storage when emissions from manure are released into the air and the organic material in the manure decomposes during storage (Regina et al., 2014). Nitrous oxide is formed when microorganisms in the soil break down and convert various compounds that contain nitrogen.

Emissions from enteric fermentation by livestock accounted for $27 \%$ of the agricultural sector's calculated total emissions of carbon dioxide equivalents, while emissions from manure handling accounted for about $12 \%$ and nitrous oxide emissions from soils around 60\% (Statistikcentralen 2013b, p. 30).

Total emissions from the agricultural sector fell by more than $10 \%$ between 1990 and 2011. The fall was partly due to decreases in the use of chemical fertilizers and the number of cattle. The largest decline occurred at the beginning of the reporting period, after which emissions varied very little (Regina et al. 2014, p. 13; Statistikcentralen 2013b, p. 32).

In fertilizer year 1990/1991, farms used 202,462 tonnes of nitrogen nutrients in fertilizers. In fertilizer year 1991/1992, the corresponding figure was 163,229 tonnes, and in 2010/2011 it was 146,189 tonnes (Tike 2003, page 93: Tike 2012, p. 74).

The production of synthetic nitrogen fertilizer causes nitrous oxide and carbon dioxide emissions, which are recorded as industrial emissions. Most of the fertilizers used in Finland are manufactured in Finland by Yara Suomi Oy. Imports of fertilizers are small, but growing in significance (Agriculture and Forestry 2008). Yara Suomi Oy announced on its website that the fertilizer they sell has given rise to less than $3.6 \mathrm{~kg}$ of carbon dioxide equivalent per $\mathrm{kg}$ of nitrogen. If one multiplies the above factor by the amount of nitrogen that was sold as fertilizer to farms in fertilizer year 2010/2011, the result is the emission of 0.5 million tonnes of carbon dioxide equivalents in 2011. (This does not take into account the fact that a small proportion of inorganic nitrogen fertilizer was imported from countries such as Russia, where production methods are more energy intensive). 


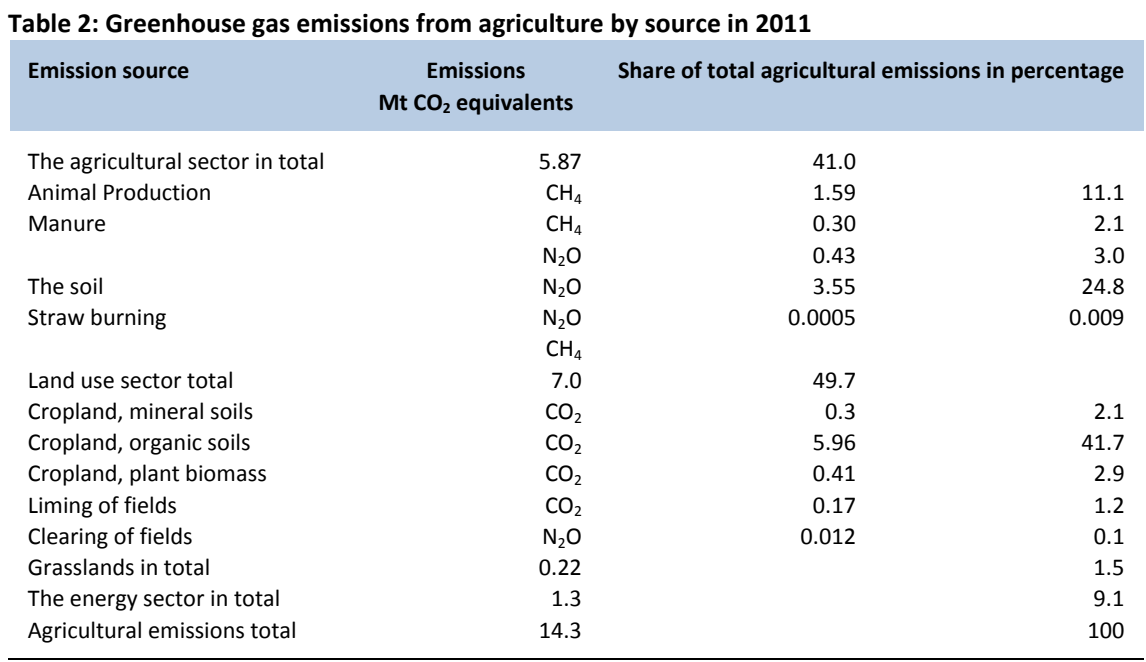

(After Ollikainen et al. 2014, p. 21).

\section{Nitrous oxide}

Nitrous oxide is produced when microorganisms break down and convert various compounds that contain nitrogen. Nitrous oxide emissions arise when nitrogen is added to the soil in the form of manure, fertilizers or sewage sludge, where plants fix the nitrogen and the crop residues and organic matter in peat and peat soils subsequently decompose (Regina et al. 2014, p. 12).

Nitrous oxide emissions from agriculture have declined since 1990. This decrease is partly because the use of chemical fertilizers has decreased, and partly because emissions from manure management have decreased (Statistikcentralen 2013b, Table 19).

Agricultural emissions of nitrous oxide were about 12.7 thousand tonnes in 2012, which is approximately $60 \%$ of Finland's total nitrous oxide emissions. This is about 3.8 million tonnes carbon dioxide equivalents and contributing to $6 \%$ of Finland's total greenhouse gas emissions.

Nitrous oxide emissions from the cultivated land have decreased by more than $10 \%$ since 1990 . This decrease is partly due to the decreased use of nitrogen fertilizer. The increased area of organic soils in the culture, by contrast, has led to increased emissions (Regina et al. 2014, p. 13).

In Finland, the production of nitric acid for fertilizers and other applications is the only industry that gives rise to emissions of nitrous oxide. These emissions decreased significantly when new technology was introduced in factories in Siilinjärvi and Nystad in 2009 (Statistikcentralen 2013b, p. 26-28). Much of the fertilizer produced by these 
factories is exported. Emissions from industry do not count as emissions from agriculture.

In 2012, total nitrous oxide emissions in Finland were 21.0 thousand tonnes. ${ }^{18}$ Agriculture's share was 12.7 thousand tonnes, equivalent to 3.9 million tonnes of carbon dioxide equivalents.

Figure 1 Finland's total emissions of nitrous oxide according to source for the years 1990-2011

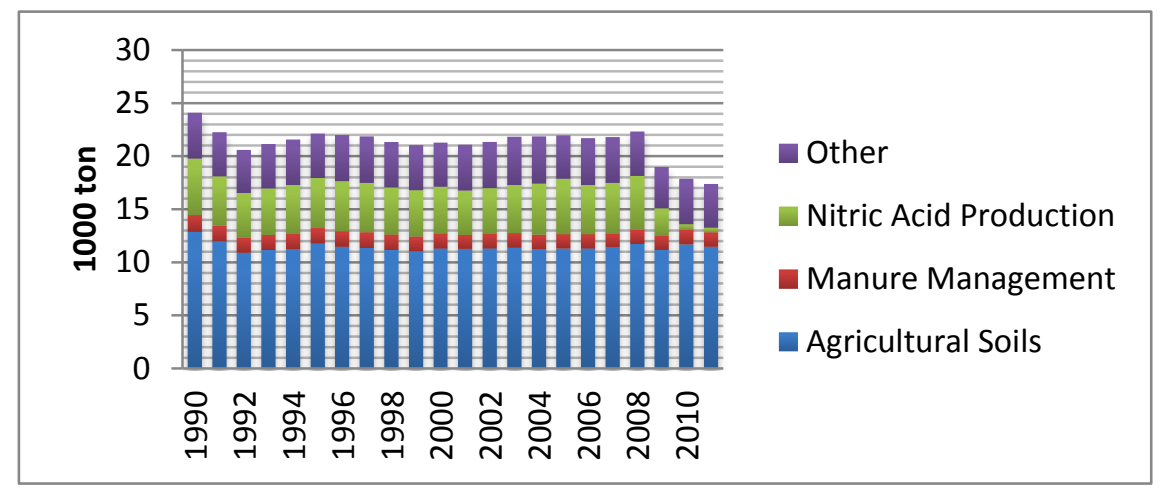

Source: European Environmental Agency (a). ${ }^{19}$

\section{Methane}

Most of the methane emissions in agriculture come from ruminants. The gas is formed naturally during their digestive process. In 2011, cattle accounted for $89 \%$ of methane emissions from enteric fermentation by livestock (Statistikcentralen 2013b, p. 30). Methane can also be formed when the fertilizer is broken down anaerobically.

In 2012 methane emissions from agriculture were around 85 thousand tonnes, which about $43 \%$ of all methane emissions, translated into 197 thousand tonnes. ${ }^{20}$

This is equal to 1.8 million tonnes of carbon dioxide equivalents, which was roughly one third of agricultural sector's greenhouse gas emissions and around 3\% of Finland's total greenhouse gas emissions.

The amount of cattle has decreased 30\% from 1990 to 2011, but the methane emissions from digestion have not reduced correspondingly.

\footnotetext{
${ }^{18}$ Including land LULUCF sector. Total nitrous oxide emissions excluding the land use sector stood at 17.0 thousand tonnes in 2011.

${ }^{19}$ Figure 1, Figure 2 and Figure 3 produced by Kaisa Lindqvist, Air Pollution \& Climate Secretariat. 20 Including land LULUCF sector. The total methane emissions excluding the land use sector were 200,200 tonnes in 2011.
} 
Methane emissions from manure management have also increased due to changes in manure management practices.

The number of cattle fell by more than 30\% between 1990 and 2011 . Methane emissions from digestion have not reduced correspondingly. The production of milk and meat per animal has increased and hence so has the emissions per animal (Statistikcentralen 2013b, p. 32).

Figure 2: Finland's total emissions of methane according to source for the years 1990 to 2011

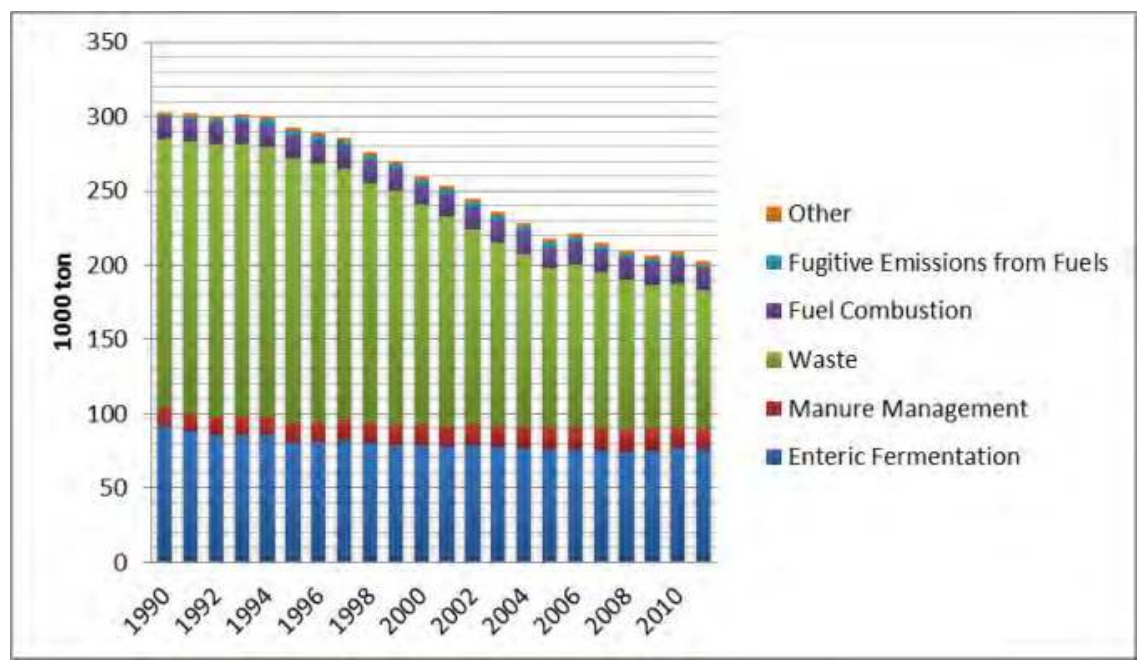

Source: European Environmental Agency (a).

Although livestock numbers have decreased, the level of methane emissions from manure management has increased. This is because the use of slurry tanks has become more common. Methane emissions from slurry tanks are a factor of ten higher than in manure management practices where the manure is handled as dry material. In the case of nitrous oxide emissions, the situation is the opposite, i.e. nitrous oxide emissions are significantly less when the manure is in slurry form. Overall, the increased number of slurry tanks has led to some reductions in greenhouse gas emissions from manure management in terms of carbon dioxide equivalents (Statistikcentralen 2013b, p. 32).

\section{Carbon dioxide}

Emissions from agricultural land totalled 6.8 million tonnes of carbon dioxide equivalents in 2011. This figure includes 6 million tonnes from cultivated organic soils, 0.3 million tonnes from mineral soils, 0.2 million tonnes from liming of fields, 0.4 million tonnes from the clearing of woodland (biomass) to create more farmland, and 0.01 million tonnes of 
carbon dioxide equivalents due to nitrous oxide emissions from field clearing (Regina et al. 2014, p. 14).

Emissions from grasslands, which include abandoned farmland and grassland that is more than five years old, were estimated to be 0.2 million tonnes of carbon dioxide equivalents in 2011. This figure includes 0.8 million tonnes of emissions from organic soils and a carbon sink of 0.5 million tonnes of mineral soils (Regina et al. 2014, p. 13, 15).

Carbon is stored in the soil in the form of plant residues, or when manure or sewage sludge is applied to the soil. Part of the plant residues and the organic material in the manure decomposes into carbon dioxide, but some is stored in the soil without breaking down (Regina et al. 2014, p. 14). If the organic material is stored in the soil it may provide a carbon sink.

The largest changes in soil carbon stocks occur when there is a change in land use. Carbon dioxide emissions from soil into the air occur, for example, when forest is cleared to create fields and the previously undisturbed soil surface is exposed to microorganisms and broken down as a result of tillage (Regina et al. 2014, p. 14).

In the course of time large amounts of carbon have been stored in organic soils, because plant material decomposes slowly when the water table is high. Decomposing microorganisms will work much faster when the soil is drained, and this can lead to the release of several tonnes of carbon per hectare (Regina et al. 2014, p. 14).

During the years 2000-2009 about 95,000 hectares of new arable land came into use. Of the cleared fields about $30 \%$, or about 30,000 hectares were of organogenic soil type. Of Finland's arable land area about $10 \%$ is peat soils (Niskanen and Lehtonen, 2014).

Greenhouse gas emissions derived from energy consumption in the agricultural sector accounted for 1.3 million tonnes of carbon dioxide equivalents in 2011 (Statistikcentralen 2013b, p. 31).

The annual energy consumption of farms is approximately $12,000 \mathrm{GWh}$. Fuel for work accounts for $33 \%$, fuel for heating $27 \%$, fuel for drying grains $18 \%$ and electricity for $22 \%$ of consumption. Additionally horticulture (including greenhouse production) accounted for about 2000 GWh of energy a year (Niemi et al. 2013, p. 34).

\section{Ammonia}

In 2012 ammonia emissions from agriculture were 37 thousand tonnes, which is around $90 \%$ of the total ammonia emissions. Cattle manure accounts for $60 \%$ of these emissions. The majority of these emissions come from the storage of manure in livestock housing and manure ap- 
plication on fields. Low emissions also arise from grazing (Grönroos, 2009, pp. 25-26).

Over the past two decades there has been no significant changes in the amount of ammonia emissions from agriculture even though the numbers of animals have decreased. There is a close correlation between the amount of nitrogen excreted and the amount of milk produced.

Figure 3: Finland's total emissions of ammonia according to source for the years 1980 to 2011

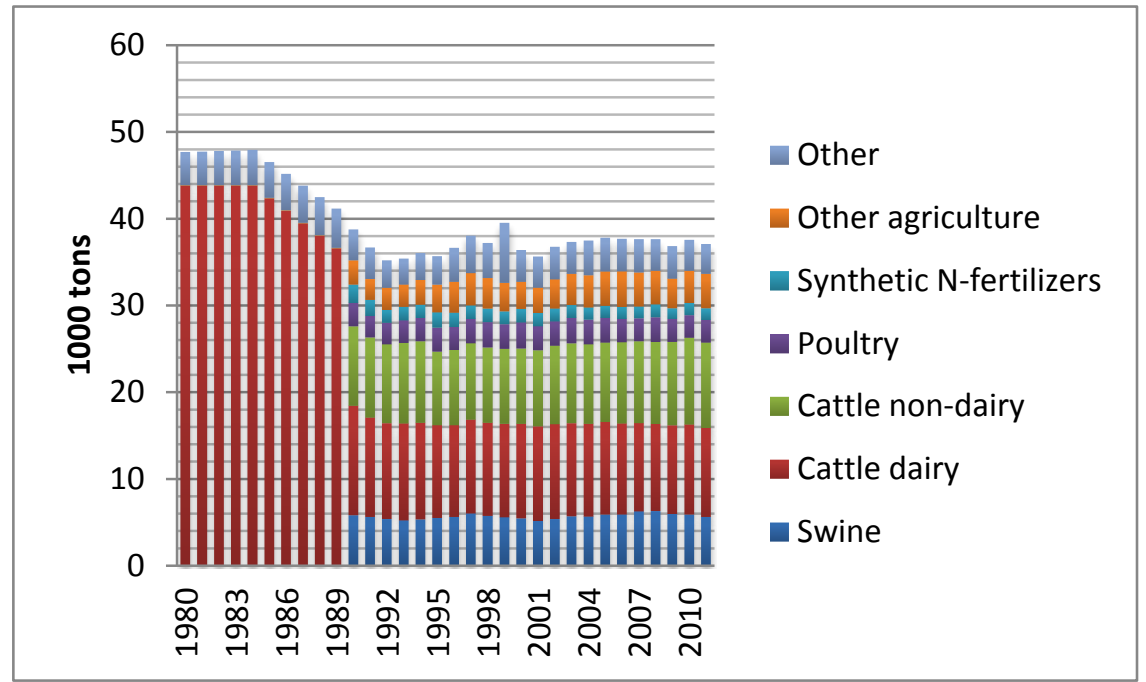

Source: European Environmental Agency (b).

\section{Emission forecasts}

Regina et al. (2014) refers to forecasts that are intended to show how greenhouse gas emissions from agriculture will look in the future. The baseline scenario assumes that there will be no major changes in agricultural policy and in the prices of agricultural goods in the coming decades. Agricultural sector emissions will remain near current levels for the time period 2011-2035. The area of organogenic farmland will continue to increase, but not as rapidly as in the early 2000s. Nitrogen fertilization levels will rise if grain prices remain at a high level. This leads to higher emissions. Without any mitigation measures, emissions from the agricultural sector will rise by 5.9 million tonnes to 6.0 million tonnes by 2020 (Regina et al. 2014, pp. 17-18).

Emissions from the land use sector are expected to rise, unless special measures are taken. Under the baseline scenario, emissions will increase from the current level by 0.5 million tonnes by 2020 and 
0.9 million tonnes by 2030 . The projected increase is primarily due to fact that the area of organogenic farmland is expected to increase.

\section{Actions and regulations}

\section{Support system}

In Finland, a set of agri-environmental measures was established as part of the rural development programme for mainland Finland for the period 2003-2007.21 This programme contained several measures affecting emissions. The measured were updated for the new period 2014-2020.

Table 3: Agri-environmental measures in the rural development plan for mainland Finland for 2014-2020 that affects air pollution and climate emissions

\begin{tabular}{|c|c|}
\hline Measure & Objectives in terms of air emissions \\
\hline Well-balanced use of fertilizers & Reduced emissions of nitrous oxide \\
\hline $\begin{array}{l}\text { Recycling nutrients and organic } \\
\text { materials (between farms special- } \\
\text { ised either in crops or animals) }\end{array}$ & Reduced greenhouse gas emissions by improving the quality of soil \\
\hline Spreading of slurry in fields & Reducing ammonia emissions \\
\hline Management of run-offs & Reduced greenhouse gas emissions, especially from organic lands \\
\hline Cultivation of grassland & $\begin{array}{l}\text { Reduced carbon dioxide emissions from arable land. Prevents carbon } \\
\text { stocks in soil from being consumed, promoting the binding of carbon }\end{array}$ \\
\hline Land cover in winter & in the soil \\
\hline
\end{tabular}

\section{Regulations}

The Nitrates Directive (91/676/EEC), implemented in Finland under nitrate regulation $(931 / 2000)$, applies to the whole country. This regulation is being revised (2014). The regulation in effect limits the use of nitrogen fertilizer, regulates how and when farms can spread fertilizer, and regulates the methods for storage of manure. The regulation affects not only emissions of nitrates, but also other emissions, including nitrous oxide and ammonia.

${ }^{21}$ Åland has its own rural development programme. 


\section{Tables and figures}

Table 1: Finnish exports and imports of agricultural products in 2011.

Table 2: Greenhouse gas emissions from agriculture by source in 2011.

Table 3: Agri-environmental measures in the rural development plan for mainland Finland for 2014-2020 that affects air pollution and climate emissions.

Figure 1: Finland's total emissions of nitrous oxide according to source for the years 1990-2011.

Figure 2: Finland's total emissions of methane according to source for the years 1990 to 2011.

Figure 3: Finland's total emissions of ammonia according to source for the years 1980 to 2011. 
Nordic Council of Ministers

Ved Stranden 18

DK-1061 Copenhagen K

www.norden.org

\section{Nordic agriculture air and climate}

This report constitutes the main outputs of the project "Pathways to a Nordic food system that contributes to reduced emissions of greenhouse gases and air pollutants." The overall goals are to present the baseline data regarding the Nordic agricultural sector, its greenhouse gas and ammonia emissions, the regulatory framework and support systems, and conflicts of interest. The report aims to describe pathways to a Nordic food system that contributes to achieving the climate target of below 2 (or 1.5) degrees of warming and the air pollution target of zero exceedance of critical loads and critical levels regarding ammonia emissions.

The Nordic region has diverse geological and climatic conditions that make certain types of agricultural production more vulnerable than others.

The policy recommendations aim to serve as input to different policies at EU, Nordic and national level.

TemaNord 2015:570

ISBN 978-92-893-4319-0 (PRINT)

ISBN 978-92-893-4321-3 (PDF)

ISBN 978-92-893-4320-6 (EPUB)

ISSN 0908-6692

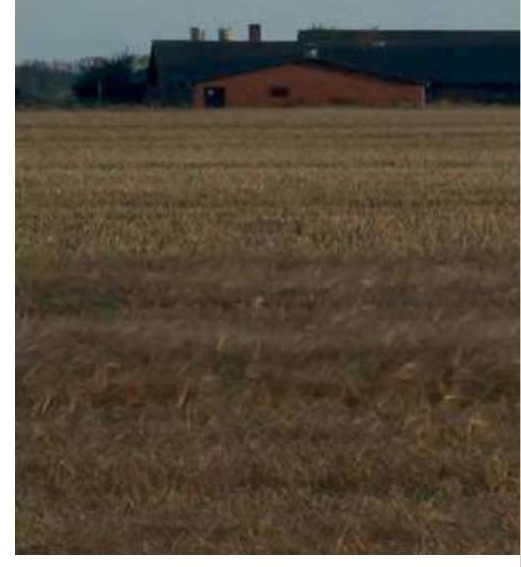

